UNIVERSIDADE DE SÃO PAULO

FACULDADE DE ECONOMIA, ADMINISTRAÇÃO E CONTABILIDADE

DEPARTAMENTO DE CONTABILIDADE E ATUÁRIA

PROGRAMA DE PÓS-GRADUAÇÃO EM CONTROLADORIA E CONTABILIDADE

RELAÇÃO ENTRE ESTRUTURAS ORGANIZACIONAIS E INDICADORES DE DESEMPENHO DAS ORGANIZAÇÕES NÃO-GOVERNAMENTAIS DO ESTADO DE SÃO PAULO

Andson Braga de Aguiar

Orientador: Prof. Dr. Gilberto de Andrade Martins

SÃO PAULO

2004 
Prof. Dr. Adolpho José Melfi

Reitor da Universidade de São Paulo

Profa. Dra. Maria Tereza Leme Fleury

Diretora da Faculdade de Economia, Administração e Contabilidade

Prof. Dr. Reinaldo Guerreiro

Chefe do Departamento de Contabilidade e Atuaria

Prof. Dr. Fábio Frezatti

Coordenador do Programa de Pós-Graduação em Ciências Contábeis 


\title{
RELAÇÃO ENTRE ESTRUTURAS ORGANIZACIONAIS E INDICADORES DE DESEMPENHO DAS ORGANIZAÇÕES NÃO-GOVERNAMENTAIS DO ESTADO DE SÃO PAULO
}

\author{
Dissertação apresentada ao \\ Departamento de Contabilidade e Atuaria da \\ Faculdade de Economia, Administração e \\ Contabilidade da Universidade de São Paulo \\ como requisito para obtenção do título de \\ Mestre em Ciências Contábeis.
}

Orientador: Prof. Dr. Gilberto de Andrade Martins 
Dissertação defendida e aprovada no Departamento de Contabilidade e Atuária da Faculdade de Economia, Administração e Contabilidade da Universidade de São Paulo Programa de Pós-Graduação em Ciências Contábeis, pela seguinte banca examinadora:

Aguiar, Andson Braga de

Relação entre estruturas organizacionais e indicadores de desempenho das organizações não-governamentais do Estado de São Paulo / Andson Braga de Aguiar. -- São Paulo, 2004.

$175 \mathrm{f}$.

Dissertação (Mestrado) - Universidade de São Paulo, 2004

Bibliografia.

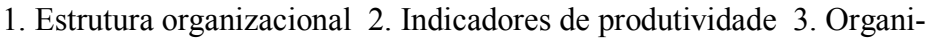
zação não-governamental I. Faculdade de Economia, Administração e Contabilidade da USP II. Título.

$$
\text { CDD }-658.1
$$


Para Carolina Soares 
Aproveito este espaço para registrar a importância de algumas pessoas para a realização desta pesquisa. Primeiramente, nenhuma gratidão será proporcional ao que me foi ensinado, direta e indiretamente, por meus pais - Jacira Braga e Manoel Aguiar - e meus irmãos - Ivina, Alan e Charles (in memmoriam). Aos amigos da Vila, assim como aos que a ela se agregaram, agradeço pelos momentos sempre presentes e marcantes. Aos mestres Célia Braga e Osório Cavalcante, que me inspiraram a seguir essa jornada, minha maior gratidão é passar adiante essa inspiração. Agradeço os inestimáveis e fundamentais apoios que recebi de João Coridon e Maria Esther. Sou grato ao Prof. Dr. Fábio Frezatti pelas oportunidades concedidas e pela confiança depositada. A cada um dos professores com quem tive o privilégio de conviver ao longo de onze disciplinas, a gratidão é pelos valiosos ensinamentos. Aos colegas com quem convivi durante cinco semestres, sou grato pelo apoio e troca de experiências. Agradeço aos que formam a secretaria da FEA - em especial à Valéria - e aos que formam a biblioteca e a UPD da FEA, assim como aos membros do Departamento - em especial à Cristina Inácio -, pelo importante apoio operacional e administrativo. A cada ONG participante desta pesquisa, a gratidão é pela cooperação e pela oportunidade de tempo concedida. Sou grato aos membros da Banca Examinadora - Prof. Dr. André Fischer e Prof. Dr. Takeshi Tachizawa - pelas pertinentes e apropriadas sugestões transmitidas no Exame de Qualificação. À Fundação de Apoio à Pesquisa do Estado de São Paulo, fico agradecido por possibilitar a viabilização desta pesquisa. Agradeço à Profa. Esther pelas valiosas revisões gramaticais. Ao Prof. Dr. Gilberto Martins, a quem cabe uma parte significativa do mérito que esta pesquisa possa ter, sou grato pelos rumos indicados e por seu comprometimento. Por fim e essencialmente, à Carolina Soares, pelos inúmeros e intraduzíveis momentos compartilhados ao longo dos últimos cinco anos, não um agradecimento, mas profunda afeição e carinho. 
"Não é dos seus discursos e nas suas idéias que se me depara a sua grandeza, senão unicamente nos seus atos e na sua vida".

Herman Hesse 


\section{RESUMO}

Esta pesquisa identifica e analisa as relações entre os aspectos básicos que determinam as estruturas organizacionais - sob a ótica de Henry Mintzberg - e indicadores de desempenho operacional das Organizações Não-Governamentais do Estado de São Paulo. Subsidiariamente, analisa o relacionamento entre estruturas organizacionais e área de atuação, idade, tamanho e composição das receitas. Os aspectos básicos representam os parâmetros de design e os fatores situacionais. Os indicadores de desempenho são analisados sob os aspectos quantitativos e qualitativos. Os indicadores quantitativos aplicados foram: índice de aplicação de recursos na atividade meio, índice de aplicação de recursos na atividade fim, produtividade de mão-de-obra e produtividade de capital. Quanto aos qualitativos, identificam-se os principais fatores com os quais as entidades pesquisadas estão comprometidas no sentido de satisfazer os beneficiários na prestação dos serviços. Realizou-se uma pesquisa de campo, dentro de uma abordagem hipotético-dedutiva, envolvendo 34 entidades ligadas à Associação Brasileira de Organizações Não-Governamentais, por meio de um roteiro para condução de entrevistas. Detectou-se, na análise do conjunto das ONGs, três arranjos organizacionais predominantes - burocracias profissionais, adhocracias e estruturas missionárias - e, na análise de cada ONG, uma ausência de configurações puras, sugerindo três conjeturas: presença de estruturas híbridas; transições estruturais; uma configuração não contemplada na tipologia original de Mintzberg. Verificou-se que a maior parte dos recursos financeiros é aplicada na atividade fim e que predominam baixos índices de produtividade de mão-de-obra e de capital, independentemente da metodologia adotada. Observou-se que 'identificar as necessidades dos usuários' e 'manter um relacionamento com polidez e respeito' são os dois principais fatores de qualidade. Constatou-se que todos os tipos organizacionais estão relacionados com entidades pequenas e jovens. Verificou-se que entidades próximas de burocracias profissionais encontram-se relacionadas às áreas de educação/pesquisa e discriminação racial e de gênero e que a maior parte de seus recursos origina-se de agências de cooperação internacional; ONGs próximas de adhocracias estão associadas às áreas sócioambiental e defesa de direitos e apresentam maior diversificação de fontes de recursos; e ONGs próximas de estruturas missionárias estão relacionadas à defesa de direitos e obtêm a maior parte de seus recursos de agências governamentais. Observou-se que entidades próximas de burocracias profissionais apresentam melhores indicadores quantitativos de desempenho, enquanto que, por outro lado, aquelas próximas de adhocracias associam-se com piores indicadores quantitativos de desempenho; entidades próximas de estruturas missionárias apresentam indicadores de desempenho intermediários aos alcançados pelos dois outros arranjos organizacionais. Os resultados demonstram que entidades próximas de burocracias profissionais alcançam melhores indicadores de desempenho, rejeitando a hipótese de que ONGs próximas de estruturas missionárias sejam as que apresentem melhores indicadores de desempenho. Sugere-se a realização de estudos que verifiquem qual das três conjeturas acerca das estruturas organizacionais em ONGs pode ser corroborada. 


\begin{abstract}
This research investigates the relationship between the fundamental aspects that set organizational designs - under Mintzberg' view - and operational performance indicators of Nongovernmental Organizations in the state of São Paulo. On the subsidiary way, it explores the relationship between organizational designs and activity sector, age, size, and funds composition. The fundamental aspects correspond to the parameters of design and situational factors. The performance indicators are analyzed in their quantitative and qualitative aspects. Indexes of resources application on secondary activities and main activities, labor productivity and capital productivity were employed to analyze the quantitative indicators. As for the qualitative aspects, the main factors with which the examined entities are under obligation, aiming to satisfy the beneficiaries, were analyzed. This inquiry embraces a hypothetical-deductive approach and performs a field research with 34 entities affiliated to Nongovernmental Organizations Brazilian Association in order to guide interviews. This paper, considering the set of NGOs, discerns three predominant organizational designs professional bureaucracies, adhocracies and missionary. Moreover, considering each NGO, it detects an absence of pure types. Those considerations imply in three conjectures: presence of hybrid configurations; structural transitions; and a new design not contemplated in the Mintzberg' original typology. This analysis verifies that most of the financial resources are applied in the main activity and low indexes of labor productivity and capital are predominant, regardless the used methodology. It observes that 'identifying users needs' and 'maintaining a relationship with courtesy and respect' are the two main quality factors. This investigation observes that all organizational designs are related to young and small entities. It verifies that entities close to professional bureaucracies are related to the fields of education/research and racial or genre bias and the majority of their funds comes from international cooperating agencies. The NGOs close to adhocracies are associated to the social-environmental and human rights defense areas and show a greater diversity of fund resources; the NGOs close to missionary types are associated to human right defense area and obtain the greatest part of their funds from governmental agencies. This inquiry states that entities close to professional bureaucracies show better performance quantitative indicators, whereas, on the other hand, those close to adhocracies are associated to worse performance quantitative indicators; entities close to missionary designs show intermediate performance indicators. The results set forth that entities close to professional bureaucracies achieve better performance indicators, so they reject the hypothesis that NGOs close to missionary designs would be the ones to show better performance indicators. Further research would verify which of those conjectures regarding the organizational designs in NGOs can be corroborated.
\end{abstract}




\section{SUMÁRIO}

1 INTRODUÇÃ O.............................................................................................. 7

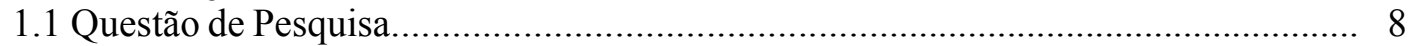

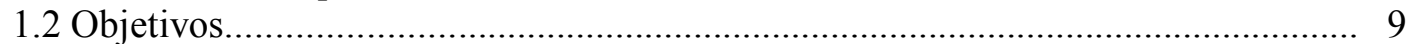

1.3 Hipótese de Pesquisa........................................................................ 10

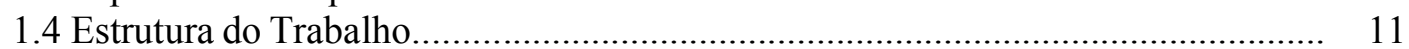

2 REFORMA DO ESTADO, TERCEIRO SETOR e ONGs...................................... 13

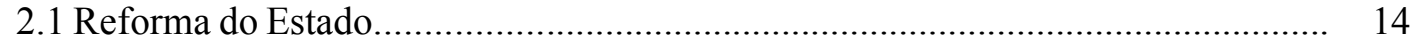

2.1.1 Características do Estado Moderno........................................................ 15

2.1.2 Propostas de Reforma do Estado......................................................... 16

2.1.3 Reforma do Estado no Brasil................................................................... 17

2.1.4 Plano Diretor da Reforma do Aparelho do Estado................................... 19

2.2 Terceiro Setor - Justificativas, Surgimento e Contexto Atual........................... 20

2.2.1 Justificativas para a Existência do Terceiro Setor................................... 23

2.2.2 Surgimento do Termo 'Terceiro Setor' e Outras Denominações................ 25

2.2.3 Entidades que Compõem o Terceiro Setor.............................................. 27

2.2.4 Modelo Tri-Setorial............................................................................... 29

2.2.5 Parcerias Público x Privado e Captação de Recursos................................ 31

2.3 ONGs - Origem, Características e Forma de Atuação....................................... 34

2.3.1 Origem e Significado do Termo 'ONG' ............................................... 36

2.3.2 Evolução e Principais Características....................................................... 38

2.3.3 Desafios Atuais.......................................................................... 45

TEORIAS ORGANIZACIONAIS E TIPOLOGIAS DE ESTRUTURAS
ORGANIZACIONAIS..................................................................................... 50

3.1 Organização e Estrutura Organizacional.......................................................... $\quad 50$

3.2 Evolução das Teorias do Design Organizacional............................................ 52

3.3 Abordagem da Configuração Organizacional.................................................... 59

3.3.1 Mecanismos de Coordenação................................................................ 61

3.3.2 Partes-Chave da Organização.............................................................. 63

3.3.3 Descrição dos Parâmetros de Design........................................................ 65

3.3.3.1 Design das Posições Individuais................................................ 65

3.3.3.2 Design da Superestrutura........................................................ 71

3.3.3.3 Design dos Vínculos Laterais.................................................... 74

3.3.3.4 Design do Sistema de Tomada de Decisão...................................... 77

3.3.4 Fatores Situacionais........................................................................... 79

3.4 Tipologias de Estruturas Organizacionais...................................................... 83

3.4.1 Tipologia da Configuração das Estruturas Organizacionais....................... 85

3.5 Características Organizacionais de Organizações Não-Governamentais.............. 93

4 AVALIAÇÃO DE DESEMPENHO............................................................................... 98

4.1 Avaliação de Desempenho - Aspectos Iniciais e Dimensões............................... 98

4.2 Avaliação de Desempenho em ONGs.......................................................... 103

5 METODOLOGIA................................................................................................ 110

5.1 Apresentação do Roteiro de Entrevista e Pré-Teste........................................... 112

5.1.1 Bloco I do Roteiro de Entrevista.......................................................... 113

5.1.2 Bloco II do Roteiro de Entrevista......................................................... 113

5.1.3 Bloco III do Roteiro de Entrevista...................................................... 115

5.1.4 Bloco IV do Roteiro de Entrevista....................................................... 115

5.2 Procedimentos para Análise da Eficácia em ONGs.......................................... 116

5.3 Plano de Análise e Interpretação dos Resultados............................................. 118 


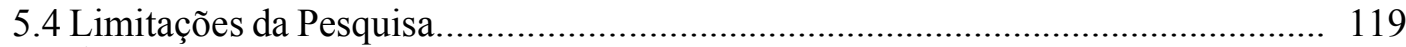

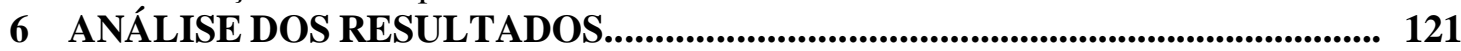

6.1 Identificação e Análise da Estrutura Organizacional Predominante..................... 121

6.2 Análise da Relação entre o Tipo Organizacional a Área de Atuação, a Idade, o

Tamanho e a Composição das Receitas.

6.3 Análise dos Indicadores de Desempenho.......................................................... 136

6.4 Análise da Relação entre Estruturas Organizacionais e Indicadores de

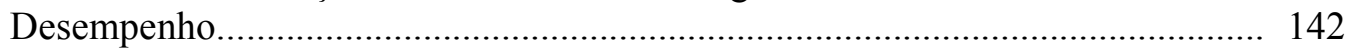

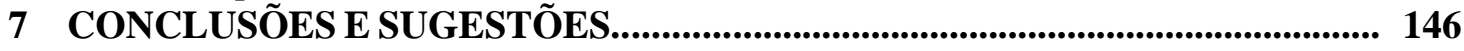

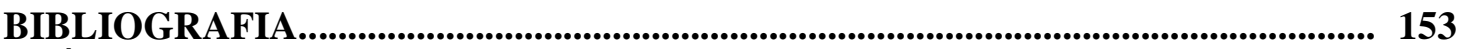

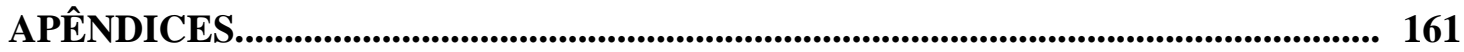

Apêndice A - Roteiro de Entrevista.......................................................................... 162

Apêndice B - Lista das Organizações Não-Governamentais que Participaram da

Pesquisa - por ordem alfabética........................................................................... 167 


\section{LISTA DE TABELAS}

Tabela 1 - Artigos que discutem a Teoria das Organizações em entidades do Terceiro Setor - ENANPAD 1997-2003.

Tabela 2 - Entidades do Terceiro Setor, por natureza jurídica, criadas durante os anos de 1999 e 2001.

Tabela 3 - Origem das ONGs - ABONG 2002.

Tabela 4 - Principais áreas temáticas de atuação das ONGs - ABONG 2002 _.............. 43

Tabela 5 - Âmbito de atuação por estado - ABONG 2002 ....................................... 44

Tabela 6 - Fontes de financiamentos das ONGs - ABONG 2002 ............................. 45

Tabela 7 - Fontes de financiamento e sua proporção no orçamento total - ABONG 2002

Tabela 8 - Número de Pessoas ocupadas segundo o nível de escolaridade - ABONG 2002

Tabela 9 - Distribuição de freqüência absoluta de parâmetros de design.

Tabela 10 - Distribuição de freqüência absoluta para base de agrupamento................... 123

Tabela 11 - Distribuição de freqüência absoluta para tamanho da Cúpula Estratégica... 124

Tabela 12 - Distribuição de freqüência absoluta para tamanho do Núcleo Operacional.

Tabela 13 - Distribuição de freqüência absoluta para tamanho do Restante da Entidade.

Tabela 14 - Distribuição de freqüência absoluta para a descentralização em suas duas dimensões.

Tabela 15 - Distribuição de freqüência absoluta para as dimensões ambientais............. 126

Tabela 16 - Distribuição de freqüência absoluta para o fator situacional idade.............. 128

Tabela 17 - Distribuição de freqüência absoluta para o fator situacional tamanho......... 128

Tabela 18 - Distribuição de freqüência absoluta para controle externo.......................... 128

Tabela 19 - Aderência conceitual de cada ONG aos tipos organizacionais.................... 130

Tabela 20 - Identificação da quantidade de ONGs em cada configuração

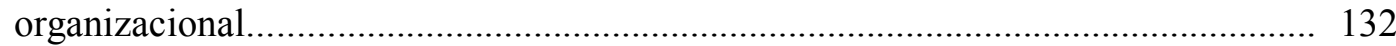

Tabela 21 - Composição dos fatores predominantes na determinação da estrutura organizacional das ONGs.....

Tabela 22 - Relacionamento entre estruturas organizacionais e área de atuação............. 133

Tabela 23 - Relacionamento entre estruturas organizacionais e idade........................... 134

Tabela 24 - Relacionamento entre estruturas organizacionais e tamanho....................... 134

Tabela 25 - Relacionamento entre estruturas organizacionais e composição das receitas

Tabela 26 - Distribuição de freqüência do índice de aplicação dos recursos na atividade meio.

Tabela 27 - Distribuição de freqüência do índice de aplicação dos recursos na atividade fim

Tabela 28 - Distribuição de freqüência do índice de produtividade de mão-de-obra...... 138

Tabela 29 - Distribuição de freqüência do índice de produtividade de mão-de-obra, exceto voluntários.

Tabela 30 - Distribuição de freqüência do índice de produtividade de mão-de-obra utilizando o 'número de beneficiários diretos'.

Tabela 31 - Distribuição de freqüência do índice de produtividade de mão-de-obra utilizando o 'número de beneficiários diretos' e excluindo os voluntários.

Tabela 32 - Distribuição de freqüência do índice de produtividade de capital 
Tabela 33 - Distribuição de freqüência do índice de produtividade de capital utilizando o 'número de beneficiários diretos'

Tabela 34 - Freqüências observadas dos fatores de qualidade indicados pelas ONGs

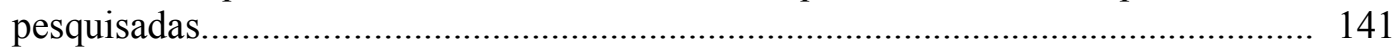

Tabela 35 - Relação entre estruturas organizacionais e índice de aplicação dos recursos na atividade meio.................................................................................. 142

Tabela 36 - Relação entre estruturas organizacionais e índice de aplicação dos recursos na atividade fim................................................................................... 143

Tabela 37 - Relação entre estruturas organizacionais e produtividade de mão-de-obra.. 144

Tabela 38 - Relação entre estruturas organizacionais e produtividade de capital........... 144

Tabela 39 - Relação entre estruturas organizacionais e fatores de qualidade................. 145 


\section{LISTA DE QUADROS}

Quadro 1 - Setores do Estado, forma de propriedade e atuação..................................... 20

Quadro 2 - Abordagens combinadas para o desenvolvimento da comunidade............... 31

Quadro 3 - Classificação dos princípios de Fayol.......................................................... 53

Quadro 4 - Diferenças entre as variáveis do grupo formal e as do grupo informal......... 55

Quadro 5 - Parâmetros de design - abordagem da configuração de Mintzberg .............. 61

Quadro 6 - Relacionamento entre as partes-chave da organização e os mecanismos de coordenação

Quadro 7 - Especialização do trabalho por parte da organização................................. 67

Quadro 8 - Comparação entre a estrutura funcional pura e a estrutura por projeto

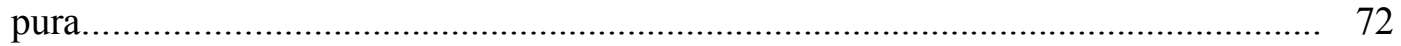

Quadro 9 - Matriz de relação entre estabilidade e complexidade do ambiente............... 82

Quadro 10 - Tipos de estruturas em função do tamanho e sua característica principal.... 84

Quadro 11 - As seis configurações básicas - teoria de Mintzberg................................. 85

Quadro 12 - Síntese das dimensões das seis configurações organizacionais................... 91 


\section{LISTA DE FIGURAS}

Figura 1 - Dimensões da parceria entre Estado e Terceiro Setor.................................. 32

Figura 2 - Abordagens clássicas da administração.................................................... 53

Figura 3 - Seis partes básicas da organização.............................................................. 63

Figura 4 - Relacionamentos entre o planejamento das decisões e das ações e o controle

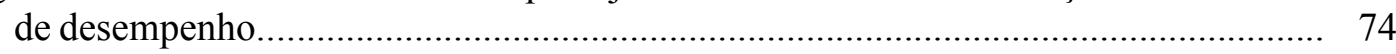

Figura 5 - Relacionamentos entre tamanho e estrutura organizacional....................... 80 


\section{INTRODUÇÃO}

Desde a pré-história o ser humano forma, dentre outras, organizações - familiares, políticas, comerciais, filantrópicas, sociais etc. - que, na sociedade atual, fazem parte do cotidiano das pessoas, sendo as principais responsáveis pelo fornecimento dos bens e serviços necessários para a subsistência humana.

As organizações podem ser agrupadas de diversas formas. Uma dessas é pela área de atuação; assim, existem as que atuam no setor automotivo, outras no setor de construção etc., de acordo com os critérios adotados pela publicação Melhores e Maiores da Revista Exame. Uma classificação mais ampla, utilizada pelo Instituto Brasileiro de Geografia e Estatística (IBGE), agrupa-as em quatro setores: 1) agropecuária, 2) indústria, 3) transporte e comunicação e 4) energia. Uma terceira classificação segmenta-as conforme suas finalidades e constituição jurídica: sem fins lucrativos e de direito público, com fins lucrativos e de direito privado, ou sem fins lucrativos e de direito privado. Bastante discutida atualmente, tal divisão se refere aos três seguintes setores: Primeiro Setor, formado pelo Estado, composto pela administração direta e indireta; Segundo Setor, composto por empresas de direito privado com fins lucrativos; e Terceiro Setor, formado por uma diversidade de organizações de direito privado sem fins lucrativos que, evidentemente, não pertencem aos dois primeiros setores.

Independente da natureza jurídica ou econômica, as organizações existem para atingir seus fins de forma eficaz. Conseqüentemente, para aquelas que compõem o Terceiro Setor não é diferente, pois também buscam ser eficazes na consecução de seus objetivos sociais.

O conjunto de entidades denominado Organizações Não-Governamentais (ONGs) representa um importante componente do Terceiro Setor. Como as demais entidades desse setor, as ONGs possuem finalidades diversas - basicamente relacionadas a aspectos sociais e são de direito privado e sem fins lucrativos.

Diversas abordagens organizacionais foram desenvolvidas visando contribuir para a eficácia das organizações, mas, por outro lado, poucas foram aquelas que tiveram por objeto entidades sem fins lucrativos e não governamentais como as ONGs. Fischer \& Fischer (1994) enfatizam esse aspecto ao afirmarem que poucos estudos e pesquisas, no âmbito da Teoria das Organizações, foram realizados focalizando tal conjunto de entidades, com exceção do artigo sobre a passagem do grupo cultural Olodum para uma gestão empresarial. Considerando-se, por exemplo, o Encontro Nacional da Associação Nacional de Pós-Graduação em Administração (ENANPAD), percebe-se a inexpressiva quantidade de artigos tratando esse tema. A Tabela 1 apresenta os números dos últimos sete ENANPADs. 
Tabela 1 - Artigos que discutem a Teoria das Organizações em entidades do Terceiro Setor - ENANPAD 1997-2003

\begin{tabular}{|l|c|c|c|c|c|c|c|}
\hline & 1997 & 1998 & 1999 & 2000 & 2001 & 2002 & 2003 \\
\hline ONG & 2 & 1 & 1 & 0 & 0 & 3 & 1 \\
\hline Terceiro Setor & 1 & 0 & 1 & 1 & 1 & 1 & 3 \\
\hline Total & 3 & 1 & 2 & 1 & 1 & 4 & 4 \\
\hline
\end{tabular}

Fonte: www.anpad.org.br

Entidades com natureza similar às ONGs são importantes sob diversos aspectos. Salamon (1999, p. 15-17), por meio de pesquisa sobre entidades do Terceiro Setor de diversas partes do mundo, destaca quatro significativas contribuições que justificam essa importância: 1) realizam funções de serviço, quais sejam: prover bens coletivos, adaptar políticas gerais às circunstâncias e necessidades locais, promover inovação e endereçar necessidades não satisfeitas; 2) incorporam valores nacionais fundamentais às iniciativas que buscam propósitos públicos, além de promoverem pluralismo, diversidade e liberdade; 3) são peças fundamentais ao mobilizarem uma mais ampla atenção pública para problemas e necessidades sociais (advocacy); e 4) criam e sustentam o que se conhece por capital social. Assim, estruturas organizacionais que possibilitam a essas entidades o desenvolvimento de suas ações de forma eficaz têm, além do aspecto econômico, um papel social relevante.

É em função da crescente relevância das ONGs, no contexto social das últimas décadas, e da limitação de estudos cujo objeto sejam essas entidades - sobretudo no âmbito da teoria organizacional com foco no caso brasileiro - que se desenvolveu esta pesquisa.

A investigação parte de uma premissa fundamentada na abordagem de configurações das estruturas organizacionais, proposta por Henry Mintzberg (2001, 2003), teórico e pesquisador em Teoria das Organizações: quando a estrutura organizacional é determinada pela consistência entre parâmetros de design e fatores situacionais, a organização tende a obter melhores índices de desempenho na consecução dos objetivos traçados.

\subsection{Questão de pesquisa}

Mintzberg (2001, 2003), em sua abordagem de configuração organizacional, utiliza uma tipologia por meio da qual agrupa as organizações dentro de seis distintas configurações das estruturas organizacionais, as quais devem ser determinadas pela consistência entre parâmetros de design e fatores situacionais para que a entidade tenda a ser eficaz. Considerando-se, assim, tal proposta, pode-se questionar a existência de uma estrutura 
organizacional predominante entre as ONGs; pode-se ainda discutir se ela de fato torna a entidade mais eficaz ou se existirá outra com condição para fazê-lo. Uma outra questão é se a afirmação de Mintzberg $(2001,2003)$ sobre a eficácia das estruturas organizacionais é válida para as ONGs. Com base nesses preceitos teóricos, elaborou-se a seguinte questão orientadora e motivadora desta pesquisa:

Qual a relação existente entre as configurações das estruturas organizacionais e os indicadores de desempenho operacional das ONGs do Estado de São Paulo?

A escolha da tipologia de Mintzberg $(2001,2003)$ deveu-se à abrangência quando comparada a outras, pois busca identificar um conjunto amplo de variáveis interdependentes que podem influenciar a estrutura organizacional de uma entidade, muitas delas, consideradas isoladamente nas demais tipologias.

Com base na análise dos resultados, tem-se por expectativa que, ao final desta pesquisa, atinjam-se as seguintes contribuições:

- contribuir com o desenvolvimento de estudos práticos acerca de estruturas organizacionais para ONGs;

- identificar os parâmetros de design e os fatores situacionais que predominam nas estruturas organizacionais das ONGs objeto de estudo;

- apresentar um perfil das ONGs, considerando parâmetros de design e fatores situacionais que definem estruturas organizacionais; e

- contribuir com a atividade social das ONGs ao destacar as estruturas organizacionais que possam torná-las eficazes.

\subsection{Objetivos}

Tendo por base os aspectos até aqui analisados, especificou-se o objetivo principal deste estudo nos seguintes termos:

Identificar e analisar a relação entre aspectos básicos que determinam as estruturas organizacionais e indicadores de desempenho operacional das ONGs do Estado de São Paulo.

Portanto, uma primeira etapa refere-se à identificação dos aspectos básicos parâmetros de design e fatores situacionais - que determinam o mecanismo de coordenação privilegiado e a parte-chave da organização.

Uma segunda etapa refere-se à mensuração de indicadores de desempenho operacional diretamente relacionados com a missão da ONG. Essa mensuração foi composta de duas 
dimensões: uma quantitativa, medida através de índices parciais de produtividade e índices de aplicação de recursos; e outra qualitativa, medida através do comprometimento da ONG com a satisfação dos beneficiários por meio da qualidade dos serviços prestados.

Por fim, essas duas etapas foram relacionadas com o intuito de identificar como esse relacionamento se comporta, ou seja, se existe uma estrutura organizacional que é privilegiada entre as ONGs, objeto do estudo, e se tal estrutura está vinculada a indicadores com melhor desempenho; ou se existe uma estrutura organizacional que, mesmo não sendo hegemônica, está relacionada a indicadores com melhor desempenho operacional.

Considerando esses aspectos, foram determinados os objetivos específicos deste estudo que, conforme Martins (2002, p. 32), “[...] balizará todas as demais ações, possibilitando menor risco de fugas por parte do pesquisador”. Dessa forma, são os seguintes os objetivos específicos:

- identificar qual a estrutura organizacional, dentro da tipologia de Mintzberg (2001, 2003), que predomina entre as ONGs objeto do estudo;

- investigar se as estruturas organizacionais adotadas pelas ONGs representam configurações puras, segundo a teoria de Mintzberg (2001, 2003);

- dimensionar os indicadores de desempenho operacional das ONGs considerando suas produtividades, seus índices de aplicação de recursos e comprometimento com a satisfação dos beneficiários através da qualidade dos serviços prestados;

- contrastar tipos de estruturas organizacionais com indicadores de desempenho operacional;

- contrastar tipos de estruturas organizacionais com atividade principal; idade; tamanho; e composição das receitas.

\subsection{Hipótese de Pesquisa}

Analisando-se as pesquisas empíricas acerca das características organizacionais das ONGs, constata-se que, geralmente, são entidades pequenas, utilizam pouco sistema de planejamento e controle, são guiadas pela missão social que defendem, cujos colaboradores participam por se identificarem com os valores defendidos e os objetivos sociais da entidade.

Dentro da tipologia de estruturas organizacionais de Mintzberg (2001, 2003), existe um tipo denominado 'Missionária'. Esse modelo de estrutura possui parâmetros de design e fatores situacionais que tendem a se aproximar das características organizacionais de ONGs. 
Por esse motivo, considerou-se que essas entidades tendem a apresentar estruturas organizacionais que se aproximam de uma estrutura organizacional Missionária.

De forma resumida, as características de uma organização missionária são:

- a organização é dominada por sua ideologia;

- tende haver uma divisão não muito rígida de trabalho;

- pouca especialização de cargos;

- pouca diferenciação, ou seja, a entidade não parece apresentar partes;

- tem na socialização dos valores e crenças o mecanismo de padronização;

- representa uma completa forma de descentralização na tomada de decisões;

- pouca formalização do comportamento;

- pouquíssimo uso de planejamento e sistemas de controle;

- não depende de treinamento profissional externo; e

- ambiente simples.

Quando uma organização tem a sua estrutura organizacional determinada pela consistência entre os parâmetros de design e os fatores situacionais, ela tende a ser eficaz na consecução de seus objetivos, considerando os recursos disponíveis.

Assim, elaborou-se a seguinte hipótese que será analisada no desenvolvimento da pesquisa: quanto mais uma ONG se aproxima de estruturas organizacionais missionárias, melhores tendem a ser seus indicadores de desempenho operacional.

\subsection{Estrutura do Trabalho}

Este estudo foi dividido em cinco partes principais. A primeira representa essa introdução em que foi feita a apresentação da pesquisa. A segunda corresponde ao referencial teórico que contempla a fundamentação necessária para a análise dos resultados. Essa parte envolve três capítulos. O primeiro traz comentários acerca da reforma do Estado e do surgimento, conceituação, dentre outras características, do Terceiro Setor, com o intuito de contextualizar as ONGs nesse universo. O segundo se refere às abordagens organizacionais e tipologia das estruturas organizacionais. Nesse capítulo, faz-se uma breve evolução das abordagens organizacionais até a abordagem da configuração das estruturas organizacionais; apresentam-se as tipologias de estruturas organizacionais encontradas na bibliografia consultada, com enfoque na tipologia proposta por Henry Mintzberg; e analisam-se alguns estudos empíricos relativos às estruturas organizacionais em ONGs. O terceiro capítulo do 
referencial teórico está relacionado à avaliação de desempenho. Algumas propostas de análise de desempenho voltadas, sobretudo, para empresas, são apresentadas nesse capítulo; adicionalmente, propostas de análise de desempenho específicas para ONGs e/ou Terceiro Setor são referidas. A terceira parte deste estudo envolve aspectos relacionados à metodologia de pesquisa. São apresentados os métodos de coleta e análise dos dados; faz-se a caracterização do objeto de estudo; apresenta-se o roteiro de entrevista, destacando-se tanto os quatro blocos que o compõe como a realização do pré-teste; e expõe-se a metodologia para mensuração da eficácia em ONGs. A quarta parte registra os resultados obtidos e a análise desses resultados, com base no referencial teórico. A quinta parte apresenta, além das conclusões da pesquisa, sugestões para futuros estudos. 


\title{
2 REFORMA DO ESTADO, TERCEIRO SETOR E ONGs
}

\author{
"A boa sociedade é a que alcança um equilíbrio entre governo, \\ mercados e ordem civil” (GIDDENS, 2001b, p.167).
}

Com o reconhecimento de que o Estado estava tendo dificuldades para cumprir com seus objetivos sociais, passou a ser proposta uma mudança em sua forma de atuação e, portanto, em seu gerenciamento, marcadamente burocrático, de maneira que se permitisse uma descentralização na prestação dos serviços sociais. A referida mudança tem um importante impacto no reconhecimento da existência de um Terceiro Setor formado por uma diversidade de entidades com origens e formas de atuação diferentes.

No entanto, entidades sem fins lucrativos que não fazem parte do âmbito administrativo do Estado e que têm por finalidade a prestação de serviços sociais à comunidade existem praticamente desde que o ser humano se organiza em grupos para atingir determinadas finalidades. Apesar disso, até recentemente, elas não eram consideradas parte de um mesmo setor, tal como os órgãos da administração direta e indireta do Estado que formam o Primeiro Setor, e as entidades com fins lucrativos que formam o Segundo Setor.

Dessa forma, as entidades que formam o Terceiro Setor ganham maior visibilidade a partir do momento em que se admite sua capacidade de prestar os mesmos serviços sociais próprios do Estado, mas de forma mais eficaz, devido à maior agilidade e estreito contato com as comunidades a que se destinam tais serviços.

Dentre as entidades que compõem o Terceiro Setor incluem-se as Organizações NãoGovernamentais (ONGs) as quais ocupam lugar de destaque no contexto brasileiro entre as entidades sem fins lucrativos por sua forma de atuação peculiar. Isso decorre do ambiente político, marcadamente autoritário, no qual germinaram, o que fez crescer o interesse por parte de acadêmicos e da sociedade em geral em melhor conhecê-las.

O presente capítulo teve por objetivo traçar as principais características das ONGs, considerando o contexto no qual surgiram e as mudanças ocorridas nas últimas décadas que lhes impuseram uma mudança de perspectiva. Inicialmente foram consideradas as propostas para reforma do Estado, destacando tanto a abordagem da Terceira Via, segundo Anthony Giddens, quanto o Plano Diretor da Reforma do Aparelho do Estado, elaborado pelo Ministério da Administração Federal e Reforma do Estado (MARE) - esse tópico foi incluído por se aceitar que o Terceiro Setor, de uma forma geral, e as ONGs, em particular, podem ser mais bem entendidos quando não são considerados como um fenômeno isolado. Em seguida, foram descritas as justificativas para a existência do Terceiro Setor, apresentando o contexto 
atual, em que são destacadas suas principais entidades e respectivas características, bem como seu relacionamento com o Estado. Por fim, foram relacionados os aspectos julgados os mais significativos acerca da origem, desenvolvimento e perspectivas atuais das ONGs.

O objetivo dessa contextualização não é resolver as questões conceituais que se apresentam tanto no que se refere à aceitação de um Terceiro Setor, quanto à definição desse e de quais entidades o formam, mas tão-somente, apresentar as características básicas que são, senão um consenso entre aqueles que estudam o Terceiro Setor, aquelas que se apresentam com maior freqüência dentro da bibliografia estudada. Nesse sentido, sua importância reside na contribuição que fornece à compreensão do surgimento das ONGs e de suas características e formas de atuação.

\subsection{Reforma do Estado}

Críticas à forma de atuação do Estado têm sido uma constante entre diversos estudiosos. As principais recaem em sua excessiva burocratização que dificulta tanto sua capacidade em prestar serviços sociais à comunidade quanto uma melhor utilização dos recursos disponíveis, ou seja, sua ineficácia e ineficiência. Coelho (2002, p. 44-45), por exemplo, destaca que "a pressão para que o Estado seja mais eficiente no provimento das necessidades sociais é cada vez maior, justamente, no momento em que ele enfrenta graves dificuldades econômicas e tem cada vez menos capacidade de responder a essa cobrança".

Pimenta (1998) é da opinião que um novo conceito de Estado está se delineando para o Século XXI. Enumera entre os principais fatores de aceleração no processo de transformação do Estado "[...] o atual contexto das grandes tendências mundiais relacionadas à globalização, a progressos na tecnologia da informação e à emergência da sociedade civil organizada". Como conseqüência, "no mundo todo, a administração pública tem sido submetida a um processo de reforma que busca adequar seu perfil e suas capacidades ao surgimento de um novo Estado, que está nascendo como resposta às grandes tendências $[. .$.$] ”.$

Cardoso (1999) e Kettl (1999) consideram o processo de reforma do Estado um fenômeno mundial. Para Przeworski (1999, p. 39) o objetivo dessa reforma é a criação de instituições que dêem poder ao aparelho do Estado para fazer apenas o que deve ser feito, ou seja, impedir que o Estado se envolva em atividades fora de seu âmbito de atuação.

Osborne \& Gaebler (1995, p. 12), dentro do contexto norte-americano, consideram que o " [...] tipo de governo que se desenvolveu durante a era industrial, com suas burocracias lentas e centralizadas, preocupado com normas e regulamentos, sujeito a cadeias de comando 
hierárquicas, deixou de funcionar bem. [...] Tornaram-se inchados, ineficientes, funcionando com desperdício”. Destacam que, diante do ambiente contemporâneo, as instituições precisam ser flexíveis e adaptáveis, capazes de produzir bens de alta qualidade com alta produtividade.

No âmbito da América Latina, Glade (1999, p. 123) salienta que, durante os anos 80 e 90, dois processos aconteceram simultaneamente: o ajustamento estrutural da economia e a reforma do aparelho administrativo do Estado. Na esfera brasileira, Pereira (1999, p. 239) afirma que a crise do Estado "[...] se caracteriza pela perda da capacidade [...] em coordenar o sistema econômico de forma complementar ao mercado". Para esse autor, essa crise assume quatro dimensões, dentre elas, a do modo de intervenção do Estado e da forma burocrática pela qual o Estado é administrado. Como conseqüência das referidas crises, Pereira (1999, p. 257) enumera dois objetivos pretendidos com a reforma do Estado: 1) em curto prazo, facilitar o ajuste fiscal e 2) em médio prazo, tornar a administração pública mais eficiente e moderna, tendo por alvo o atendimento aos cidadãos.

\subsubsection{Características do Estado Moderno}

Antes de comentar mais detidamente a reforma do Estado defendida pelos autores supracitados, torna-se necessário compreender as características do Estado Moderno que provocaram tais propostas. Bonavides (1982) caracteriza as três principais formas ideológicas do Estado Moderno surgidas a partir do Século XVIII.

A primeira delas é o Estado Liberal cujo apogeu ocorre no Século XIX. Bonavides (1982) apresenta dois aspectos básicos dessa forma ideológica: a) prevalência dos valores individuais sobre os valores estatais ou sociais; e b) crença profunda nas virtudes abstratas da lei e confiança nos instrumentos constitucionais. Dallari (2002, p. 277) considera que o Estado Liberal é conseqüência da ascensão política da burguesia. Seu principal defeito, segundo Bonavides (1982), foi estabelecer um distanciamento entre sociedade e Estado, bem como enfatizar os direitos individuais.

A segunda forma ideológica é o Estado Social ou welfare state ou ainda Social Democracia que emerge com a crise do Estado Liberal ocorrida após a Primeira Guerra Mundial (1914-1918). Di Pietro (2002, p.20) destaca que é no início do século XIX que se iniciam as reações contra o Estado Liberal. Dessa forma, o Estado Social surge como alternativa à forma do Estado Liberal. Bonavides (1982) afirma que seu traço marcante é o de representar um agente ativo dos negócios econômicos, sociais e culturais, numa clara tentativa de reconciliar Sociedade e Estado, disciplinar o capital e fazer justiça ao trabalho. 
A terceira forma ideológica é o Estado Socialista que se apresenta como poder da classe trabalhadora. Giddens (2001a, p. 13) destaca que o socialismo inicialmente surge como um corpo de conhecimento que se opunha ao individualismo. A União das Repúblicas Socialistas Soviéticas (URSS) foi a força máxima dessa ideologia de Estado cujo ponto de partida ocorreu em 1917. Entretanto, como sentencia Hobsbawm (1997, p.481), “com o colapso da URSS, a experiência do 'socialismo realmente existente' chegou ao fim”.

No entanto, Giddens (2001a) considera que não apenas o Estado Socialista chegou ao fim, como também os outros dois, ou seja, o Estado Liberal - ou Neoliberal que surge na busca de recuperar conceitos liberais - e o Estado Social, em suas formas tradicionais. Esse autor defende que todas essas formas ideológicas precisam ser reformulados para atenderem às necessidades atuais surgidas com as mudanças políticas e econômicas ocorridas.

\subsubsection{Propostas de Reforma do Estado}

Diante das necessidades referidas no tópico anterior, Giddens (2001a, p. 36) propõe uma forma ideológica representada pela Terceira Via ou 'Governança Progressista' que “[...] se refere a uma estrutura de pensamento e de prática política que visa adaptar a socialdemocracia a um mundo que se transformou fundamentalmente ao longo das duas ou três últimas décadas" e que deveria ter por princípio orientador básico a reforma do Estado como forma de aprofundar e ampliar a democracia. Portanto, conclui o autor, essa proposta busca transcender não apenas a social democracia como também o neoliberalismo.

Como sentencia Giddens (2001b, p. 11), a expressão 'Terceira Via' não é nova, tendo sido utilizada no passado por diversas tendências políticas. Por algum tempo, continua o autor, o termo caiu em desuso e somente nos últimos anos foi ressuscitado nos diálogos políticos, especialmente na Grã-Bretanha e nos Estados Unidos. Os fundamentos da Terceira Via como Giddens (2001b, p.57-60) propõe, são, a seguir, enunciados de forma objetiva:

- dá atenção ao centro político - a oposição entre esquerda e direita não ajuda a esclarecer muitas questões e problemas na política contemporânea;

- considera que uma ordem democrática, bem como uma economia de mercado eficaz, dependem de uma sociedade civil florescente;

- propõe construir um novo contrato social - baseado no teorema "não há direitos sem responsabilidades"; 
- esfera econômica - busca desenvolver política de incentivos fiscais que reconcilie mecanismos de crescimento econômico com reforma estrutural do welfare state;

- busca fomentar uma sociedade diversificada baseada em princípios igualitários; e

- considera a globalização com seriedade.

Giddens (2001b, p. 64) afirma que um dos objetivos da política da Terceira Via é, portanto, tornar o Estado eficaz e ágil como outros setores da economia através de uma reforma estrutural que promova um processo de desburocratização, busque benchmarking de padrões e torne mais autônomos os níveis inferiores da organização. Uma parte básica da política da Terceira Via destacada por Giddens (2001a, p. 88-89) é a promoção da sociedade civil em que "Estado e sociedade civil deveriam agir em parceria, cada um para facilitar a ação do outro, mas também para controlá-la”. Giddens (2001b, p. 86) é da opinião que:

[...] se desenvolvidas de maneira eficaz, os grupos do terceiro setor podem oferecer opções de escolha e capacidade de resposta na prestação de serviços públicos. Eles podem também ajudar a promover a cultura cívica local e algumas formas de desenvolvimento comunitário.

Para tanto, continua Giddens (2001b, p. 64), essas comunidades precisam ser ativas e empreendedoras, o que pode contribuir para o desenvolvimento econômico, através de uma combinação entre a eficácia nos negócios e o estímulo a programas sociais. Como resultado, entidades do Terceiro Setor ganham visibilidade devido ao papel que lhes é atribuído. Coelho (2002, p. 38) reforça esse ponto quando afirma que as funções dos atores que interagem com o Estado precisam ser revistas sempre que as finalidades desse são repensadas.

Falconer (1999, p. 36) lembra que mesmo não havendo parentesco entre os conceitos de Terceiro Setor e a política da Terceira Via "[...] é fácil traçar uma relação entre um 'terceiro' e outro como indicativos da existência de alternativas a socialismo e liberalismo, a estatismo e privatismo". No entanto, Salamon (1994) alerta que não se pode limitar a atuação e crescimento do Terceiro Setor à 'Terceira Onda', pois aquele afeta não apenas regimes democráticos mas também autoritários, seja em nações desenvolvidas ou subdesenvolvidas.

\subsubsection{Reforma do Estado no Brasil}

Quando se considera a participação brasileira nas quatro conferências para discutir as políticas da Terceira Via, pode-se afirmar que, em alguma medida, o Brasil está se inserindo em direção à política da Terceira Via. Esse direcionamento parece mais claro quando se considera a proposta de reforma de Estado lançada pelo Ministério da Administração Federal 
e Reforma do Estado ${ }^{1}$ (MARE) em 1995. Essa reforma, na percepção de Pereira (1999, p. 237), pode ser reconhecida como a terceira reforma administrativa do Brasil.

A primeira reforma administrativa do Estado brasileiro ocorre em 1936 com o objetivo de pôr fim ao estilo de administração patrimonialista, substituindo-o por outro baseado nos padrões propostos por Max Weber. Nesse estilo, o princípio básico é o mérito profissional, sendo denominado de administração pública burocrática. Acreditava-se que esse modelo era superior, entretanto, com o crescimento do Estado, a alternativa da administração pública burocrática se apresentou lenta e incapaz de atender às demandas dos cidadãos, tornando a busca pela eficiência essencial (PEREIRA, 1999, p. 241-242).

A segunda reforma administrativa do Estado ocorre em 1967, por meio do Decreto-Lei $\mathrm{n}^{\circ} 200$. Meirelles (1995, p. 631) destaca que o objetivo principal e imediato desse dispositivo legal foi fixar diretrizes e princípios que permitissem à Administração Federal funcionalidade e dinamicidade. Pereira (1999, p. 244) considera que a reforma iniciada por esse decreto “[...] representou um primeiro momento de administração gerencial no Brasil”.

A Constituição Brasileira de 1988, por sua vez, acaba promovendo um retrocesso no processo de desenvolvimento de uma administração pública gerencial. Di Pietro (2002, p.38) afirma que "Quanto à Administração Pública, a Constituição caminhou na contramão da direção. Revelou tendência inegável para a burocratização [...]”. Pereira (1999, p.246) sintetiza esse retrocesso como segue:

Por isso a Constituição sacramentaria os princípios da administração pública arcaica, burocrática ao extremo. Uma administração pública altamente centralizada, hierárquica e rígida, em que toda prioridade seria dada à administração direta, e não à indireta. A Constituição de 1988 ignorou completamente as novas orientações da administração pública.

Considerando que a Constituição de 1988 foi incapaz de perceber a crise fiscal e a crise do aparelho do Estado, no que se refere ao seu modo de intervenção e à sua forma burocrática de ser administrado, tornou-se ainda mais visível a necessidade de o Estado evoluir em direção a uma administração pública gerencial. Di Pietro (2002, p.39) afirma que “a Administração Pública brasileira vive um momento de reforma, acompanhando o movimento de globalização que vem tomando conta do mundo". Essa é, portanto, a terceira reforma do Estado Brasileiro, como referido por Pereira. Como conseqüência, foi desenvolvido o Plano Diretor da Reforma do Aparelho do Estado, elaborado pelo Ministério

\footnotetext{
${ }^{1}$ A partir de 2003, com a posse do novo Governo, esse ministério passou a ser denominado de Ministério do Planejamento, Orçamento e Gestão, tendo a frente o Ministro Guido Mantega.
} 
da Administração Federal e da Reforma do Estado (MARE) - presidido pelo então Ministro Luiz Carlos Bresser Pereira - e aprovado em 21 de setembro de 1995.

\subsubsection{Plano Diretor da Reforma do Aparelho do Estado}

O texto do Plano Diretor destaca a diferença entre reforma do Aparelho do Estado pretendida por meio desse documento - e reforma do Estado. Enquanto esta representa um projeto mais amplo que deve envolver tanto as várias áreas do Governo, como o conjunto da sociedade brasileira, aquela é mais restrita, pois está orientada apenas no sentido de tornar a administração pública mais eficiente e mais voltada para a cidadania. No entanto, como determina o Plano Diretor, para que a reforma almejada possa ocorrer, é indispensável uma redefinição do papel do Estado que se transformaria em regulador e provedor dos serviços públicos ao invés de executá-los diretamente.

Os objetivos globais da Reforma, conforme consta no Plano Diretor, são:

- Aumentar a governança do Estado, ou seja, sua capacidade administrativa de governar com efetividade e eficiência, voltando a ação dos serviços para o atendimento dos cidadãos;

- Limitar a ação do Estado àquelas funções que lhe são próprias, reservando, em princípio, os serviços não-exclusivos para a propriedade pública não-estatal e a produção de bens e serviços para o mercado e para a iniciativa privada;

- Transferir da União para os estados e municípios as ações de caráter local: só em casos de emergência cabe a ação direta da União;

- Transferir parcialmente da União para os estados as ações de caráter regional, de forma a permitir uma maior parceria entre estados e União.

São identificados no Plano Diretor quatro setores que compõem o Estado. O primeiro representa o núcleo estratégico no qual são definidas leis e políticas públicas. Nesse setor, mais importante do que a eficiência é a efetividade das decisões, ou seja, que sejam as melhores e efetivamente cumpridas. As atividades de competência desse setor são próprias de Governo, não sendo passíveis de parceria. A propriedade necessariamente tem que ser estatal.

O segundo setor componente do Estado inclui atividades que lhe são exclusivas e que estão relacionadas com o 'poder de Estado' - poder de tributar e de legislar. A propriedade, assim como no núcleo estratégico, tem que ser necessariamente estatal, sendo que a execução pode ser transferida, concedendo maior autonomia aos órgãos públicos e às entidades da administração indireta e instituição de controle de resultados.

Serviços não-exclusivos ou competitivos - terceiro setor do Estado - incluem atividades realizadas ou subsidiadas pelo Estado, consideradas de alta relevância para os direitos humanos e/ou envolvendo economias externas. Assim, não seriam adequadamente 
recompensadas no mercado por meio de cobrança dos serviços. A propriedade é a pública não-estatal. Nesse sentido, serviços não-exclusivos do Estado são passíveis de parcerias.

Por fim, tem-se o setor do Estado representado pela produção de bens e serviços para o mercado, cuja execução é feita por meio de empresas de economia mista que atuam em setores públicos e/ou considerados estratégicos. A propriedade aqui é privada.

Esses três últimos setores têm por critério fundamental o de eficiência, diferentemente do Núcleo Estratégico, cujo critério é o de efetividade. Tal fato decorre de serem esses setores aqueles que estão diretamente prestando serviços aos cidadãos. Assim, o mais importante é que todos os cidadãos sejam atendidos com qualidade e a baixo custo.

Considerados os quatro setores do Estado, identificam-se três formas de propriedade: 1) privada - voltada para a realização do lucro (empresa) ou de consumo privado (família); 2) pública estatal; e 3) pública não-estatal. Com base em tal divisão, Pereira (1999, p. 261-262) afirma “[...] que o público não se confunde com o estatal. O espaço público é mais amplo que o estatal, já que pode ser estatal ou não estatal”. Concluindo, o autor destaca que:

[...] poder-se-ia dizer que, afinal, continuamos apenas com as duas formas clássicas de propriedade: a pública e a privada, mas com duas importantes ressalvas: primeiro, a propriedade pública subdivide-se em estatal e não-estatal, ao invés de se confundir com a estatal; e segundo, as instituições de direito privado voltadas para o interesse público e não para o consumo privado não são privadas, e sim públicas não-estatais.

Com base nesses setores do Estado, percebe-se tendência em permitir ao Segundo e Terceiro Setores um campo de atuação mais amplo. Aquele podendo atuar na prestação de serviços não-exclusivos ou competitivos e na produção de bens e serviços, este, na prestação de serviços não-exclusivos ou competitivos. Em síntese, o Quadro 1, relaciona o setor do Estado, a forma de propriedade e quem pode atuar em cada setor, conforme o Plano Diretor.

Quadro 1 - Setores do Estado, forma de propriedade e atuação

\begin{tabular}{|l|l|l|}
\hline \multicolumn{1}{|c|}{ Setores do Estado } & \multicolumn{1}{c|}{ Forma de Propriedade } & \multicolumn{1}{c|}{ Atuação } \\
\hline Núcleo Estratégico & Estatal & Estado \\
\hline Atividades Exclusivas do Estado & Estatal & Estado ou Mercado \\
\hline Serviços Não-Exclusivos do Estado & Pública Não-Estatal & Mercado ou Terceiro Setor \\
\hline Produção de Bens e Serviços & Privada & Mercado \\
\hline
\end{tabular}

\subsection{Terceiro Setor - Justificativas, Surgimento e Contexto Atual}

Um conjunto de entidades sem fins lucrativos e não integrantes da estrutura administrativa do Estado vem obtendo destaque no atual contexto social, tanto no que se refere ao crescimento em seu número, quanto na importância que lhe é atribuída. Hall (1992, 
p. 13) destaca o acentuado crescimento dessas entidades no contexto norte-americano a partir, principalmente, da década de 60. Santos (apud Fernandes, 2002, p. 17), em pesquisa realizada nas cidades do Rio de Janeiro e São Paulo no ano de 1986, revela que mais de 65\% das associações civis existentes naquele ano haviam sido criadas a partir de 1970. No entanto, esse crescimento mostra sinais de declínio, ainda que o número de entidades criadas nos últimos anos seja significativo. A Tabela 2 apresenta o número de entidades do Terceiro Setor criadas no Brasil e em SP durante o período de 1999 a 2001.

Tabela 2 - Entidades do Terceiro Setor, por natureza jurídica, criadas entre os anos de 1999 e 2001

\begin{tabular}{|l|c|c|c|c|c|c|}
\hline \multirow{2}{*}{ Natureza Jurídica da Entidade } & \multicolumn{2}{|c|}{1999} & \multicolumn{2}{|c|}{2000} & \multicolumn{2}{c|}{2001 (preliminar) } \\
\cline { 2 - 7 } & Total & SP & Total & SP & Total & SP \\
\hline Fundação mantida com recursos privados & 240.810 & 63.289 & 6.619 & 1.612 & 3.511 & 852 \\
\hline Associação (condomínio, igreja etc) & 1.336 .317 & 421.566 & 381.431 & 92.098 & 161.134 & 46.776 \\
\hline Outras organizações sem fins lucrativos & 791.651 & 238.374 & 44.978 & 9.242 & 16.494 & 3.884 \\
\hline Total & 2.368 .778 & 723.229 & 433.028 & 102.952 & 181.139 & 51.512 \\
\hline
\end{tabular}

Fonte: Levantamento da RITS ${ }^{2}$ a partir de dados da RAIS (relação Anual de Informações Sociais).

A importância dessas entidades reside basicamente em sua atuação paralela ao Estado na definição de políticas públicas e na prestação de serviços sociais. Tenório (1998) destaca que "Nos últimos anos, o denominado terceiro setor tem sido apontado como uma saída para muitos dos problemas sociais da sociedade contemporânea". Marcovitch (1999, p. 125) expõe estudo sobre exclusão social na Amazônia Legal o qual “[...] revela que 67\% das iniciativas de combate à exclusão social são realizadas por organizações do Terceiro Setor e 33\% são projetos da administração pública". Tenório (1999) menciona que o espaço ocupado pelo Terceiro Setor "[...] tem-se pautado de tamanha relevância que instituições internacionais de controle e fomento creditício procuram utilizar ou estimulam governos a utilizarem esses agentes sociais como instrumentos de implantação, acompanhamento e avaliação de políticas públicas". Toro (2000, p. 35-39) apresenta quatro teses que ressaltam o papel do Terceiro Setor, especificamente, nas sociedades que designa de baixa participação:

1. contribuir para a construção do projeto de nação (visão-missão);

2. contribuir para a formação e o fortalecimento do comportamento de cidadão e da cultura democrática;

3. contribuir para a re-institucionalização do âmbito público para aumentar e fortalecer a governabilidade;

4. contribuir criando condições para tornar possível a democracia cultural.

\footnotetext{
${ }^{2}$ RITS - Rede de Informações do Terceiro Setor.
} 
Teodósio (2003) identifica quatro papéis que as entidades do Terceiro Setor podem desempenhar, isoladamente ou em conjunto, em suas relações com o Estado, a sociedade e as empresas: 1) controle da execução de políticas públicas/difusão de valores; 2) execução de políticas públicas; 3) execução autônoma de projetos sociais; e 4) influência nos processos decisórios do Legislativo e Executivo.

Em decorrência do crescimento e da importância que emerge, dentre outros motivos, em função da mudança de concepção do Estado quanto à sua forma de atuação, essas entidades passam a ser vistas como parte de um mesmo setor, a despeito das diversidades de origem, formas de atuação, constituição jurídica etc. Esse setor passa a ser denominado de Terceiro Setor, em contraposição aos dois outros: Primeiro Setor, formado pelo Estado representado por entidades de direito público e sem fins lucrativos e o Segundo Setor, representado por entidades de direito privado e com fins lucrativos. No entanto, não se pode daí concluir que essas entidades representam um fenômeno recente, ao contrário, existem desde que o ser humano se organiza em sociedade. Coelho (2002, p. 31) é da opinião que "Em maior ou menor graus, as associações voluntárias sempre estiveram presentes nas comunidades, e antecedem o surgimento do welfare state". A autora considera que nesse período tais associações estavam relacionadas com organizações religiosas e étnicas. Bava (2000, p. 48) lembra que "[...] muitos dos elementos atribuídos ao Terceiro Setor têm outras origens históricas e muitas vezes são muito mais antigos do que esta nova teoria, não expressando nada de inovador no processo social". Cita, como exemplo, as Santas Casas de Misericórdia que chegaram ao Brasil com as caravelas dos portugueses.

Landim (1997, p. 324), referindo-se ao surgimento do Terceiro Setor no Brasil, relaciona a história das associações voluntárias com a origem colonial do Estado brasileiro. Durante esse período, conforme Camargo et al (2001, p. 51-52), existia forte relacionamento entre Igreja e Governo Colonial, em que aquela agia tanto como setor público, pois fazia parte do Governo, quanto como Terceiro Setor, pois tinha sua estratégia de ação “[...] baseada no envolvimento dos membros da comunidade em prol dos menos favorecidos [...]".

É em função desses aspectos, dentre outros, que existem autores que consideram ser as entidades do Terceiro Setor, na verdade, o Primeiro Setor, dado que sua formação antecede o surgimento do Estado. Dentre esses autores, destaca-se Rifkin (2000, p. 21), para quem é “[...] preciso compreender que, quando se estabelece a civilização, em primeiro lugar, estabelece-se a comunidade (o capital social), depois surge o comércio e o governo: a comunidade sempre vem primeiro". Assim, haveria uma inversão, no sentido de que Estado seria Terceiro Setor, enquanto entidades sem fins lucrativos e não-governamentais formariam o Primeiro Setor. 
Montaño (2002, p. 54) reputa esse aspecto como uma das debilidades teóricas do termo Terceiro Setor. Para fundamentar seu ponto de vista utiliza o seguinte argumento "[...] se este [Terceiro Setor] é identificado com a sociedade civil e se, historicamente, é a sociedade que produz suas instituições, o Estado, o mercado etc., há clara primazia histórica da sociedade civil sobre as demais esferas; o 'terceiro setor' seria na verdade o 'primeiro'”. No caso brasileiro, Primeiro Setor compreende o Estado, Segundo Setor abrange as entidades com fins lucrativos, e Terceiro Setor inclui as instituições sem lucrativos e não-governamentais.

\subsubsection{Justificativas para a Existência do Terceiro Setor}

Ainda que entidades do Terceiro Setor existam desde os primórdios da organização social, apenas recentemente passa-se a aceitar a existência de um Terceiro Setor. As razões para tanto vão além das críticas feitas ao Estado quanto à sua incapacidade de prestar serviços sociais à comunidade. Salamon (1999, p. 11-15) enumera cinco razões que justificam a existência do Terceiro Setor: 1) as comunidades antecederam instituições governamentais; 2) o mercado não é capaz de fornecer bens públicos em função do problema do 'free-rider' (pessoas que se beneficiam de serviços ou produtos sem que tenham 'pago' para tanto); 3) limitações do Governo em prestar serviços públicos; 4) organizações do Terceiro Setor facilitam o exercício da iniciativa individual; e 5) o Terceiro Setor representa uma resposta à necessidade por mecanismos que expressem os sentimentos de solidariedade.

Coelho (2002, p. 83-84), tratando especificamente da questão da eficiência do Terceiro Setor frente ao Estado, apresenta alguns argumentos que justificam a existência desse setor:

1. os serviços são prestados em escala muito menor do que aqueles prestados pelo Estado, o que facilita o seu gerenciamento;

2. em função da proximidade da comunidade beneficiária dos serviços, essa pode exercer um certo controle sobre as entidades do Terceiro Setor. Esse controle, por sua vez, pode contribuir para a qualidade do serviço; e

3. o custo dos serviços prestados tende a ser inferior, principalmente em decorrência da isenção fiscal, tornando positiva a relação custo $\mathrm{x}$ benefício.

Hudson (1999, p. 265-266) refere-se a três teorias econômicas que buscam explicar as organizações sem fins lucrativos: 1) teoria dos bens públicos - existem pessoas que desejam serviços públicos além daqueles fornecidos pelo governo; 2) falha de contrato - financiadores e, em particular, doadores, não têm meios de saber se seu dinheiro está sendo bem empregado, de modo que precisam confiar numa organização que não pode obter lucro com suas doações; 
e 3) teoria do controle do consumidor - consumidores querem um serviço ou uma campanha de uma organização e ao mesmo tempo querem controlá-la. Outra teoria desenvolvida pelos economistas considera que entidades do Terceiro Setor existem em decorrência do status de 'sem fins lucrativos' para ficarem isentas de impostos ${ }^{3}$.

No contexto brasileiro, Landim (1997, p. 332) considera que existem pelo menos três temas subjacentes ao desenvolvimento do Terceiro Setor. O primeiro está relacionado à regra do Catolicismo tanto na idéia popular da filantropia quanto nas associações contemporâneas. O segundo é a regra histórica em que o Estado cria parte significativa desse setor. Por fim, o terceiro é a politização de muitas organizações que refletem interesses diversos de diferentes segmentos da sociedade brasileira. Falconer $(1999$, p. 9) destaca que "Mais do que as próprias organizações sem fins lucrativos brasileiras, foram as entidades multilaterais, com destaque para o Banco Mundial, as empresas privadas e o Governo Federal que construíram esta promessa”.

Montaño (2002, p. 23) discorda da idéia de que o Terceiro Setor seja mais eficiente do que o Estado e, por isso, não seria justificativa para retirar desse a responsabilidade da questão social. Esse autor discorda ainda da tese que defende a existência do Terceiro Setor por motivos de redução dos custos necessários para se manter a função estatal de intervir na questão social. $\mathrm{O}$ autor defende que a justificativa fundamental para a existência desse conjunto de entidades é político-ideológica, o que significa:

[...] retirar e esvaziar a dimensão de direito universal do cidadão quanto às políticas sociais (estatais) de qualidade; criar uma cultura de autoculpa pelas mazelas que afetam a população, e de auto-ajuda e ajuda mútua para seu enfrentamento; desonerar o capital de tais responsabilidades, criando, por um lado, uma imagem de transferência de responsabilidades e, por outro, a partir da precarização e focalização (não-universalização) da ação social estatal e do 'terceiro setor', uma nova e abundante demanda lucrativa para o setor empresarial.

Coelho (2002, p. 142), baseando-se em pesquisa empírica de sua autoria, afirma que “[...] os serviços prestados por essas organizações em nada diferem, em termos de qualidade, daqueles oferecidos pelas agências públicas. Entretanto, elas apresentam maiores condições de ampliação e melhoria exatamente por serem pequenas e mais ágeis”. Rosa \& Costa (2003), em estudo no qual comparam a eficiência e a eficácia entre entidades do Terceiro Setor e organizações governamentais, destacam que as primeiras sofrem problemas semelhantes aos enfrentados pelas organizações burocráticas tradicionais, tais como a rotina e o apego às

\footnotetext{
${ }^{3}$ O item c), inciso VI, do Art. 150 da Constituição Federal de 1988 do Brasil dispõe ser vedado à União, aos Estados, ao Distrito Federal e aos Municípios instituir impostos sobre o patrimônio, renda ou serviços das instituições de educação e assistência social, sem fins lucrativos, o que é ratificado pela Lei Complementar representada pelo Código Tributário Nacional.
} 
normas, sendo que as entidades governamentais, além desses problemas, sofrem outras limitações que lhes são específicas.

Ainda são poucos os estudos que confirmam ou não essa suposta 'maior eficiência' de entidades do Terceiro Setor, o que, sem dúvida, torna essa posição frágil. Em suma, as diversas justificativas para a existência de um Terceiro Setor carecem de validação. Por outro lado, ao transferir às entidades do Terceiro Setor a responsabilidade na questão social, não se pode afirmar que o Estado esteja se desvinculando dessa função completamente, pois terá ele um papel fundamental de regulador e provedor dos serviços públicos.

\subsubsection{Surgimento do Termo 'Terceiro Setor' e Outras Denominações}

Aceitando-se a existência de um conjunto de entidades que formam o Terceiro Setor, um passo seguinte se refere ao surgimento desse termo. Diversos autores destacam que o termo 'Terceiro Setor' provém do contexto norte-americano (HALL, 1992; COELHO, 2002; FALCONER, 1999). No Brasil, esse termo parece ter sido primeiramente utilizado em 1993, por Leilah Landim, pesquisadora do $\mathrm{ISER}^{4}$, quando da realização de pesquisa internacional sob iniciativa da Johns Hopkins Comparative Nonprofit Sector Project (FALCONER, 1999, p. 11). No entanto, outros termos são utilizados para designar o conjunto de entidades sem fins lucrativos e não-governamentais. Salamon \& Anheier (1997, p. 12-13) enunciam os seguintes termos por julgarem que cada um deles enfatiza determinado aspecto da realidade representada por essas organizações: setor caritativo; setor independente; setor voluntário; setor com isenção fiscal; organizações não-governamentais; economia social; e setor sem fins lucrativos.

Nesta pesquisa, adotou-se o termo Terceiro Setor a despeito das dificuldades conceituais que apresenta. Uma primeira dificuldade é quanto à sua definição que utiliza termos enfatizando o que essas entidades não são - sem fins lucrativos e não-governamentais. Fernandes (2002, p. 22) considera importantes essas duas negações no sentido que:

Importa sublinhar a diferença porque há entre ele e o governo alguma coisa em comum: ambos devem cumprir uma função eminentemente coletiva. [...] Da mesma forma, ao se dizerem 'nãolucrativas', parecem sublinhar que, apesar de não gerarem lucro, também são independentes e autogeridas assim como as empresas.

Uma segunda dificuldade é referente à definição desse termo que seja capaz de englobar a diversidade de entidades que o compõem. Uma definição genérica ou simplista

\footnotetext{
${ }^{4}$ ISER - Instituto de Estudos da Religião.
} 
pode ser obtida por meio de Thompson $(2000$, p. 41): “[...] diria que [Terceiro Setor] se trata de todas aquelas instituições sem fins lucrativos que, a partir do âmbito privado, perseguem propósitos de interesse público". Para Hudson (1999, p. 8) o termo Terceiro Setor inclui todas as organizações que:

- Têm basicamente um objetivo social em vez de procurarem gerar lucro;

- São independentes do Estado porque são administradas por um grupo independente de pessoas e não fazem parte de um departamento de governo [...];

- Reinvestem todo o seu saldo financeiro nos serviços que oferecem ou na própria organização.

Montaño (2002, p. 57) considera como sendo uma debilidade teórica o conceito de Terceiro Setor, pois envolve uma categoria não constatável na realidade, ou seja, “[...] representa um constructo ideal que, antes de esclarecer sobre um 'setor' da sociedade, mescla diversos sujeitos com aparentes igualdades nas atividades, porém com interesses, espaços e significados sociais diversos, contrários e até contraditórios”. Cardoso (2000, p.7) sentencia que não apenas o conceito Terceiro Setor, como seu perfil e seus contornos ainda não estão claros nem mesmo para muitos dos atores que o compõem.

No entanto, Hudson (1999, p. XI) refere como sendo o traço comum que une toda a diversidade dessas entidades em um único setor a de serem orientadas por valores, no sentido de que "[...] são criadas e mantidas por pessoas que acreditam que mudanças são necessárias e que desejam, elas mesmas, tomar providências nesse sentido”. Fernandes (2000, p. 29-32) apresenta quatro razões que justificam serem essas entidades agrupadas em um mesmo setor:

- contrapõem ações de governo;

- contrapõem ações do Segundo Setor;

- atribuem sentido fundamental ao conjunto das iniciativas desse Terceiro Setor; e

- enfatizam o caráter complementar entre ações públicas e privadas.

Para Thompson (2000, p. 47) o ponto em comum entre organizações do Terceiro Setor "[...] é o de colocar no centro do cenário o social, as pessoas. Se a política se estrutura cada vez mais ao redor do poder e a economia em relação ao lucro, o espaço comum do 'Terceiro Setor' são as necessidades humanas, uma certa utopia com relação ao social". Salamon (1999, p. 10-11) apresenta uma definição que denomina de operacional-estrutural por enfatizar a estrutura e operações básicas dessas entidades, ao invés de seus propósitos ou fontes de receita. Dentro desse contexto, Salamon identifica seis condições as quais certamente irão variar em grau, ou seja, para algumas será mais fácil a qualificação em um critério do que em outro. No entanto, a entidade para ser considerada parte do Terceiro Setor - nonprofit sector, 
expressão utilizada pelo autor - deverá apresentar as seis condições em algum grau, conforme caracterizadas a seguir:

- $\quad$ organizadas - entidades informais não são consideradas parte do Terceiro Setor;

- privadas - institucionalmente separadas do Governo, sendo possível que recebam suporte governamental ou mesmo tenham agentes do Governo em sua diretoria, desde que não afete a estrutura fundamentalmente privada da entidade;

- não-distribuidoras de lucro - os lucros acumulados em um dado ano devem ser aplicados na consecução da missão básica;

- autogovernada - têm seus próprios interesses e procedimentos internos de governança e não são controladas por outras entidades;

- associação voluntária - evolvem níveis significativos de participação voluntária. Tipicamente, a Diretoria é formada por voluntários, assim como, é comum a utilização de voluntários no setor administrativo;

- finalidade pública - servem propósitos públicos.

Falconer (1999, p. 44) destaca que o último atributo foi utilizado por Salamon em referência ao Terceiro Setor norte-americano. No entanto, Coelho $(2002$, p. 61) é da opinião que tais atributos são amplos o suficiente para que possam ser aplicados à realidade brasileira, inclusive esse último. Ressalva precisa ser feita no que se refere ao atributo da 'finalidade pública', tendo em vista a existência de entidades classificadas como parte do Terceiro Setor e que têm como beneficiários os próprios membros. É preciso que se tenha em mente ainda a existência de entidades informais.

\subsubsection{Entidades que Compõem o Terceiro Setor}

Com base nessas tentativas de definição, entra-se em uma outra debilidade teórica referida por Montaño (2002, p. 55), qual seja, a de determinar as entidades que compõem o Terceiro Setor. Landim (1997) agrupa tais entidades em cinco categorias: organizações da sociedade civil ou sem fins lucrativos; associações; filantrópicas, beneficentes ou de caridade; fundações; e organizações não-governamentais. Kisil (2000, p. 143) agrupa-as em três categorias conforme o tipo de serviços que é privilegiado. A primeira envolve organizações de advocacia que têm por principal objetivo "[...] fazer lobby para defender interesses, ou lutar por problemas específicos, ou grupos específicos da sociedade”. A segunda inclui organizações de caráter técnico, ou seja, aquelas que fornecem “[...] informações, serviços de 
consultoria, acesso a determinadas tecnologias, ou programas de capacitação de recursos humanos $[\ldots]$ ".. com o objetivo de tornar outras organizações sustentáveis. A terceira contém as organizações prestadoras de serviços que atuam em áreas específicas, tais como educação, saúde, habitação, bem-estar social, geração de oportunidades de emprego.

Salamon (1995, p. 53-54), por sua vez, identifica quatro tipos de organizações que compõem o Terceiro Setor: 1) funding agencies - captam recursos para outras organizações que prestam serviços sociais; 2) member-serving - fornecem bens e serviços a seus próprios membros; 3) public-benefit - contribuem com o bem-estar geral; e 4) congregações religiosas ou outras organizações que possuem essencialmente funções religiosas sacramentais.

Mais recentemente, no âmbito brasileiro, duas outras denominações vêm recebendo destaque em decorrência do interesse que tem o Estado em estabelecer parcerias com o Terceiro Setor e surgem da tentativa de adaptar a legislação brasileira à realidade dessas entidades. Quanto a esse aspecto, Coelho (2002, p. 97) considera que o impacto da legislação no Terceiro Setor é, em grande parte, responsável pelo tamanho do setor, pois a legislação concede benefícios econômicos que podem “[...] ser alcançados por elas. A ampliação ou a restrição das possibilidades legais desses benefícios pode significar a sobrevivência ou a morte de várias organizações".

A primeira dessas denominações surge com a Lei $\mathrm{n}^{\circ}$ 9.637, de 15 de maio de 1998, que dispõe sobre a qualificação de pessoas jurídicas de direito privado como Organizações Sociais (OS). Esse dispositivo legal decorre da proposta de Reforma do Estado do MARE, referida no tópico anterior. O Art. $1^{\circ}$ dessa lei destaca que: “[ [...] poderá qualificar como organizações sociais pessoas jurídicas de direito privado, sem fins lucrativos, cujas atividades sejam dirigidas ao ensino, à pesquisa científica, ao desenvolvimento tecnológico, à proteção e preservação do meio ambiente, à cultura e à saúde [...]” (SZAZI, 2001, p. 200-201). Sinteticamente, como Arantes (2000, p. 9) referencia:

[...] organizações sociais resultam da transformação dos serviços públicos em entidades públicas de direito privado que celebram com o estado um contrato de gestão, cujas atividades são controladas de forma mista pelo Estado (financiamento parcial pelo orçamento público, poder de veto e cooptação nos conselhos de administração) e pelo Mercado (cobranças de serviços prestados pela mão invisível da concorrência entre as entidades).

A segunda denominação surge com a Lei $n^{0}$ 9.790, de 23 de março de 1999, que dispõe sobre a qualificação como Organizações da Sociedade Civil de Interesse Público (OSCIP) e institui e disciplina o Termo de Parceria, dentre outras providências. Para a qualificação como OSCIP, as entidades devem ser caracterizadas como pessoas jurídicas de 
direito privado, sem fins lucrativos, e possuir objetivos sociais e normas estatutárias que atendam aos requisitos instituídos pelo referido dispositivo legal. A qualificação como entidades sem fins lucrativos decorre da não distribuição de excedentes operacionais, sob qualquer natureza, a sócios, conselheiros, diretores, empregados ou doadores, devendo ser esses aplicados na consecução do respectivo objeto social (SZAZI, 2001, p. 207-208).

No entanto, independente da denominação pela qual as entidades do Terceiro Setor são conhecidas, juridicamente, serão fundações ou associações:

Todas essas denominações referem-se a entidades de natureza privada (não-públicas) sem fins lucrativos, que juridicamente ou são associações ou fundações. Essas associações ou fundações, conforme o caso, podem pleitear a obtenção de determinados títulos ou qualificações (título de utilidade pública, qualificação como organização da sociedade civil de interesse público etc.). No entanto, sob o aspecto jurídico, a característica básica da entidade é ser associação ou fundação (BARBOSA \& OLIVEIRA, 2002, p. 13-14).

O Código Civil em vigor desde 11 de janeiro de 2003, por meio da Lei $\mathrm{n}^{0} 10.406$, de 10 de janeiro de 2002, destaca em seu art. 44, que pessoas jurídicas de direito privado podem ser representadas por associações, sociedades e fundações. No entanto, Szazi (2001, p. 27) menciona que as sociedades são instituídas, em geral, com finalidades de lucro. Dessa forma, entidades do Terceiro Setor se constituem como associações ou fundações. O Código Civil trata de associações entre os arts. 53 e $61 . \mathrm{O}$ art. 53 destaca que associações são constituídas pela união de pessoas que se organizam para fins não econômicos. As fundações são tratadas entre os arts. 62 e 69 do referido Código. O art. 62 determina que para se criar uma fundação "[...] o seu instituidor fará, por escritura pública ou testamento, dotação especial de bens livres, especificando o fim para o qual se destina, e declarando, se quiser, a maneira de administrá-la”. O parágrafo único desse artigo estabelece que uma fundação somente poderá ser constituída para fins religiosos, morais, culturais ou assistenciais.

\subsubsection{Modelo Tri-Setorial}

Independente das dificuldades teóricas relacionadas ao conceito 'Terceiro Setor' e diante das tentativas legais em contribuir para uma maior aproximação entre esse e o Estado, parece certa a existência não mais de uma visão dicotômica entre Estado e Segundo Setor. Fernandes (2002, p. 20-21) refere-se a essa mudança e menciona que em lugar do “[...] pensamento dicotômico, dividido entre interesses particulares e públicos, recupera-se o valor da tríade, afirmando-se a presença constante e eficaz de uma terceira possibilidade". Coelho 
(2002, p. 40) considera que o modelo tri-setorial sugere que mais importante que o fato de os serviços e bens serem ofertados está o de ‘como’ o são ofertados.

Fischer (2002, p. 25) enfatiza que, no Brasil, o modelo tri-setorial é uma concepção relativamente nova que somente ganhou notoriedade a partir da última década do século XX em decorrência da visibilidade adquirida pelas entidades do Terceiro Setor. Fischer (2002, p. 31) ressalta ainda que "Ele emergiu de um relativo anonimato para uma posição de importância, quando se passou a destacar as formas de organizar a participação de pessoas em torno de atividades, interesses e objetivos comuns a certos segmentos da sociedade”. Por fim, a autora menciona que a concepção tri-setorial representa:

[...] proposta de arranjo das organizações formais em uma tipologia que as cataloga em três categorias - Estado, Mercado e Terceiro Setor - de acordo com critérios predefinidos. Esses critérios variam pouco entre os autores, destacando-se comumente: a origem do capital; a propriedade do capital, dos recursos financeiros e materiais e da pessoa jurídica; a formalização jurídico-legal; a responsabilidade legal e administrativa; o tipo de atuação/missão e de atividadesfim executadas pela organização (FISCHER, 2002, p. 30-31).

Para Falconer (1999, p. 35), uma compreensão do modelo tri-setorial menos ambiciosa e, por isso mesmo, mais adequada e elucidativa, é, inicialmente, deixar de lado implicações políticas e valorativas e "[...] compreendê-lo, exclusivamente, como uma tipologia de organizações, que as classifica em três grupos 'puros' - empresas comerciais com finalidade de lucro, entidades governamentais e organizações privadas sem fins lucrativos". Para o autor, é a partir dessa compreensão que se torna possível a apreensão das " [...] qualidades constitutivas de cada tipo, seus pontos fortes e deficiências e, o que prova ser mais importante, explorar as interações entre os três grupos".

Isso porque, como Hudson (1999, p. 8) afirma, “As fronteiras não estão bem definidas. Algumas organizações são típicas do setor, outras são secundárias. Muitas compartilham os valores do setor, mas também têm características em comum com os setores público e privado". Fischer (2002, p. 32) considera esse aspecto típico do modelo tri-setorial. A autora destaca que "O modelo trissetorial contém, como características particularmente importantes de sua configuração, as áreas de interseção dos setores, as quais asseguram a consistência do conjunto [...]". Dentro desse contexto, continua a autora, surgem as entidades híbridas “[...] que não apenas fazem a interface mas carregam em si atributos de mais de um setor”.

Kisil (2000, p. 136-137) apresenta algumas características básicas em relação a cinco dimensões com o intuito de diferenciar as entidades que compõem os três setores. Essa diferenciação pode ser resumida por meio do Quadro 2. 
Quadro 2 - Abordagens combinadas para o desenvolvimento da comunidade

\begin{tabular}{|l|l|l|l|}
\hline & Governo & Mercado & Terceiro Setor \\
\hline Mecanismo principal & Estruturas democráticas & Interações de mercado & Associações, voluntários \\
\hline Tomada de decisão & $\begin{array}{l}\text { Funcionários eleitos, } \\
\text { administradores }\end{array}$ & $\begin{array}{l}\text { Produtores, individuais, } \\
\text { consumidores, investidores }\end{array}$ & Líderes e membros \\
\hline Guias de comportamento & Regulamentos & Preços & Acordos \\
\hline $\begin{array}{l}\text { Critérios para tomada de } \\
\text { decisão }\end{array}$ & Política & Eficiência & Interesse dos membros \\
\hline Modo de operação & De cima para baixo & Individualista & De baixo para cima \\
\hline
\end{tabular}

Fonte: Kisil (2000, p. 137).

Portanto, parece aceitável a existência de um Terceiro Setor e, conseqüentemente, de um modelo tri-setorial. Esse modelo tanto pode envolver entidades puras, no sentido de que apresentam características de um único setor, quanto pode apresentar entidades híbridas com características de dois ou dos três setores. É justamente em decorrência desses aspectos que passa a ser considerado mais importante o 'como' os serviços são oferecidos do que propriamente quem os oferece.

\subsubsection{Parcerias Público x Privado e Captação de Recursos}

Dentro da concepção de um modelo tri-setorial passa a existir uma interação entre as entidades que formam os três setores. De uma forma geral, o termo mais utilizado atualmente para expressar as relações entre entidades públicas e privadas é 'parceria'. Falconer (1999, p. 74) exemplifica relações que podem ser consideradas como parcerias:

[...] a participação de membros de organizações da sociedade civil em conselhos e órgãos deliberativos e decisórios de governo, a troca informal de informações, a doação de recursos a fundo perdido pelo Estado a organizações da sociedade civil, a operação conjunta de programas, a cessão de instalações ou pessoal para a operação de programas, ou até a subcontratação de agências não-governamentais para prestar serviços a agências públicas [...]”.

De forma específica, Falconer (1999, p. 75) define parceria público-privado “[...] como uma relação entre o Estado e organizações sem fins lucrativos, onde estas organizações sem fins lucrativos partilham com o Estado o papel de formulação e implementação de programas ou políticas públicas". No entanto, ressalta o autor, ainda que deva existir certo grau de equilíbrio entre os parceiros, a parceria não pressupõe a igualdade de poder ou de atribuições e responsabilidades entre as entidades.

Di Pietro (2002, p. 34) identifica quatro categorias de parceria que o Estado pode firmar com entidades privadas: 1) delegação da execução de serviço público a particulares; 2) fomento à iniciativa privada de interesse público; 3) cooperação do particular na execução de atividades próprias do Estado; 4) instrumento de desburocratização e instauração da 
Administração Pública gerencial. Salamon (2000, p. 107-109) destaca que a colaboração é um dos desafios que enfrenta o Terceiro Setor. Para esse autor a colaboração entre os três setores não significa a desconsideração das diferenças existentes entre as entidades que os formam, mas representa exatamente uma das maiores forças de cada setor. Analisando esse desafio, Salamon o especifica em três campos diferentes: 1) com o Estado; 2) com o setor empresarial; e 3) em suas próprias fileiras.

Falconer (1999, p. 75-76) segmenta as relações entre Estado e Terceiro Setor em quatro dimensões - Figura 1 - de acordo com duas variáveis, quais sejam, “[...] o grau de influência ou participação na formulação e tomada de decisões, e na implementação, ou seja, na operação de programa, projetos, ou serviços públicos”. Os quadrantes decorrentes são: 1 caracteriza parceria forte, em que o Terceiro Setor participa da formulação e da implementação de programas públicos; 2 - caracteriza parceria limitada à consulta, onde entidades do Terceiro Setor participam apenas da formulação de programas públicos; 3 caracteriza parceria limitada à implementação; 4 - caracteriza parceria que inexiste.

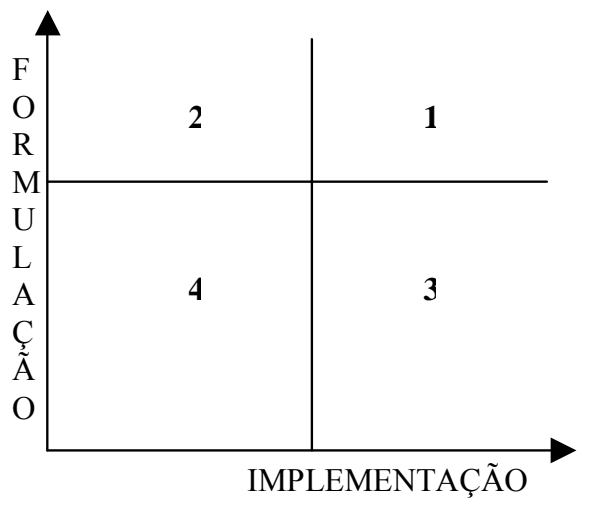

Figura 1 - Dimensões da parceria entre Estado e Terceiro Setor Fonte: Falconer (1999, p. 76)

O estabelecimento de parcerias vem suprir uma das principais debilidades do Terceiro Setor, qual seja, a sustentabilidade. Bailey (2000, p. 88) refere-se a esse aspecto dividindo-o em duas questões. A primeira diz respeito à busca de mecanismos que contribuam para o incremento de recursos; a segunda está relacionada com a necessidade de redução dos altos níveis de dependência dos financiamentos das ONGs internacionais. Por esse motivo, Drucker (1994, p. 41) destaca que entidades sem fins lucrativos necessitam de estratégias para captação de recursos, pois enquanto empresas obtêm recursos por meio da venda de produtos e o governo através de impostos, essas entidades captam recursos por meio de doadores. 
A Associação Brasileira de Organizações Não-Governamentais (ABONG, 2002a) apresenta uma publicação anual - Manual de Fundos Públicos - na qual relaciona os programas gerenciados pelo Governo Federal. Nessa publicação, a ABONG identifica financiamentos a projetos de ONGs, divididos em grandes áreas. Tal aspecto sugere, por um lado, o interesse do Estado em permitir que a execução dos serviços públicos seja descentralizada e, por outro, o interesse do Terceiro Setor em colaborar com sua execução.

Outra forma de obtenção de recursos é a qualificação como entidades de utilidade pública, seja em nível federal, estadual ou municipal. O status de utilidade pública “[...] permite às organizações beneficiadas gozarem do direito de obtenção de fundos públicos e concede a dedutibilidade de doações, no caso dos impostos federais" (FISCHER, 2002, p. 34).

Fischer (2002, p. 131) destaca que as parcerias entre os três setores permitem que as organizações envolvidas tenham um acréscimo de aprendizagem. Na visão da autora, "É difícil avaliar quem se beneficia mais dessa interação: se as empresas e as corporações do setor privado, ou as organizações do Terceiro Setor, ou os órgãos públicos, que estabelecem parcerias e redes focadas em realizar ações sociais". Soczek (2003) considera a parceria entre Estado e outros atores sociais não apenas um desejo como também uma “[...] oportunidade para a aplicação do processo de democratização do Estado, por meio da construção de um espaço público que torne possível a criação de condições para o efetivo exercício da cidadania [...]". Cruz \& Estraviz (2003) relacionam um conjunto de fontes de financiamento para o Terceiro Setor, em que, para cada qual, apresentam “[...] vantagens, motivações, além de outras características específicas de captação com cada uma delas".

A principal questão que se coloca em relação à dependência financeira do Terceiro Setor é quanto à perda de autonomia. Bailey (2000, p. 100) enfatiza esse aspecto ao afirmar que "O financiamento governamental de $\mathrm{OSCs}^{5}$ traz o perigo bem conhecido da perda da independência política e espírito crítico, especialmente no Brasil, onde a cultura política ainda não considera aceitável morder a mão que o alimenta”. Drucker $(1994$, p. 41) sentencia que quando uma entidade do Terceiro Setor se torna prisioneira da captação de recursos, apresentará problemas sérios e sofrerá sérias crises de identidade. $\mathrm{O}$ autor lembra que a captação de recursos deve ser uma atividade meio ao invés de fim, sob pena de a entidade ter sua missão subordinada a essa atividade. Além da perda de identidade, Bailey (2000, p. 102) menciona que as mudanças culturais e organizacionais necessárias para o sucesso da captação

\footnotetext{
${ }^{5}$ OSCs - Organizações da Sociedade Civil.
} 
de recursos podem fazer com que o Terceiro Setor perca qualidades tais como inovação, flexibilidade e ousadia.

Uma outra questão referente à captação de recursos, especificamente, entre Terceiro Setor e Estado é, segundo Coelho (2002, p. 151), o fato que "Para as organizações, a relação com o Estado pode significar mais recursos, o que, por um lado, leva ao crescimento da instituição, mas, por outro, gera a necessidade de estrutura e do cumprimento das exigências que vêm atreladas aos recursos". Dentre essas exigências, destaca-se a prestação de contas, sobre a qual Coelho (2002, p. 166) afirma que, "Mais do que um mero controle orçamentário que objetiva verificar se as verbas estão sendo destinadas estritamente ao cumprimento do contrato, o que se procura é a informação do bom uso dele". É dentro desse contexto que emerge o conceito de accountability. No entanto, esse conceito é mais amplo que o de prestação de contas, pois, adicionalmente, envolve características como idoneidade, integridade, responsabilidade, dentre outras (COELHO, 2002, p. 172).

Sintetizando, as entidades do Terceiro Setor têm como um de seus principais desafios o da sustentabilidade. Visando superar esse desafio, elas não podem perder de vista que essa atividade é um meio de cumprir com sua missão, ou seja, não podem considerar a captação de recursos como um fim. É possível perceber que são crescentes as possibilidades de parcerias, principalmente com o Estado, o que deixa ainda mais claro o interesse desse em transferir às entidades do Terceiro Setor determinadas questões sociais.

\subsection{Organizações Não-Governamentais - Origem, Características e Forma de Atuação}

O Terceiro Setor é formado por uma diversidade de entidades sem fins lucrativos e não-governamentais. Dentre as quais, um grupo se destaca: o das Organizações NãoGovernamentais (ONGs). Em muitos aspectos, as ONGs se assemelham às demais entidades que formam o Terceiro Setor, quando se trata, por exemplo, da questão da sustentabilidade. No entanto, possuem especificidades relacionadas às suas origens, aspecto fundamental para o entendimento de sua forma de atuação.

Tal como as demais entidades que formam o Terceiro Setor, Tachizawa (2002, p. 17) menciona que, juridicamente, as ONGs ou são associações ou fundações. Sendo que, continua Tachizawa (2002, p. 36), "Preferem [...] a primeira forma, a qual não implica a existência de um patrimônio prévio, nem de um instituidor". Esse aspecto é reforçado pela 
ABONG/AFINCO ${ }^{6}$ (2003, p. 18) que sentencia: "Por necessitarem de um fundo patrimonial expressivo para sua constituição, poucas ONGs são constituídas como fundações; a maior parte opta por constituir uma associação civil". Dessa forma, como ressalta Landim (1993, p. 20), não existe qualquer dispositivo jurídico que diferencie as ONGs das demais entidades sem fins lucrativos e não-governamentais.

Por outro lado, Landim (1993, p. 46), ao analisar a lista de entidades que se denominam ONGs, afirma que essas entidades “[...] demarcam enfaticamente uma distinção com relação ao campo das iniciativas 'assistenciais', ou 'filantrópicas', mais próximas talvez das culturas populares marcadas por outros valores [...]". Apesar disso, como relata Vakil (apud Roesch, 2002), entre as próprias ONGs não existe uma definição consensual, sendo tal fato possível de ser explicado por três fatores:

1. a própria natureza multidimensional quanto aos tipos que engloba;

2. a natureza interdisciplinar inerente na literatura a seu respeito; e

3. a variedade, pois evoluíram em diferentes estágios ao longo do tempo, muitas vezes engajando-se em diversas atividades e setores.

Caracterizando as ONGs, Tenório (2001, p. 11) destaca que são organizações sem fins lucrativos e que procuram uma forma de atuação autônoma, pois não possuem vínculo com o governo; ademais, são entidades cuja atuação é voltada ao atendimento das necessidades de organizações de base popular, complementando a ação do Estado. No entanto, Landim (1993, p. 153) menciona que as ONGs, considerando sua natureza, não existem nem para substituir o Estado, nem para complementar sua atuação. Uma definição que busca refletir a natureza dessas entidades é justamente a da $\mathrm{ABONG}$, que o faz no Art. $2^{\circ}$ de seu Estatuto como segue:

Para efeito do disposto neste estatuto, são consideradas Organizações Não Governamentais ONGs, as entidades que, juridicamente constituídas sob a forma de fundação, associação e sociedade civil, todas sem fins lucrativos, notadamente autônomas e pluralistas, tenham compromisso com a construção de uma sociedade democrática, participativa e com o fortalecimento dos movimentos sociais de caráter democrático, condições estas, atestadas pelas suas trajetórias institucionais e pelos termos dos seus estatutos.

Percebe-se, portanto, a referência feita à questão da autonomia, da atuação política e, talvez mais importante, o relacionamento junto a movimentos sociais, para que a entidade sem fins lucrativos e não-governamental possa ser considerada como ONG pela ABONG. Landim (1993, p. 28) menciona esse aspecto quando afirma que ONGs são definidas por um discurso marcadamente político, conforme pode ser percebido por meio do Estatuto da ABONG o qual

6 Publicação realizada com a parceria da Associação Brasileira de Organizações Não-Governamentais (ABONG), Administração e Finanças para o Desenvolvimento Comunitário, como parte do Programa de Apoio ao Desenvolvimento Institucional e Sustentável do Instituto Internacional de Educação do Brasil (PADIS/IIEB). 
apresenta como critérios para admissão das associadas: “a) O compromisso da ONG com a construção de uma sociedade democrática; b) O compromisso da ONG com o fortalecimento dos movimentos sociais".

As ONGs representam, portanto, um relevante componente do Terceiro Setor, sendo para alguns autores, o termo mais difundido no âmbito brasileiro. Fernandes (2002, p. 65-66) considera tal termo o principal indício que pode conduzir, na América Latina, à consideração da existência de um Terceiro Setor. Fischer \& Fischer (1994) destacam a presença significativa das ONGs, não apenas no Brasil, mas em todo o mundo.

\subsubsection{Origem e Significado do Termo 'ONG'}

Não se pode afirmar que a denominação ONG tenha sido cunhada por iniciativa das próprias entidades. Como menciona Landim (1993, p. 11), ela surgiu pela primeira vez em documentos das Nações Unidas ainda na década de 40 em referência a um amplo conjunto de entidades, porém pouco definido. A autora ressalta que já na Ata de Constituição das Nações Unidas em 1945 foi feita menção às ONGs, “[...] com as quais o Conselho Econômico e Social da ONU poderia estabelecer consultorias".

Fischer \& Fischer (1994) destacam o fato de que a expressão ONG foi criada pela ONU na década de 40, referindo-se a um conjunto de entidades não-oficiais que poderiam receber recursos financeiros "[...] para executar projetos de interesse de grupos e comunidades sociais". Dessa forma, Fischer \& Falconer (1998) afirmam que a utilização do termo 'ONG' decorre principalmente da influência dos financiadores internacionais do que propriamente de uma escolha espontânea das entidades.

Salamon (1995), tratando da importância das agências oficiais de auxílio para a expansão do 'setor voluntário', faz menção ao Banco Mundial que, na década de 70, apenas esporadicamente, apoiou ONGs em nações em desenvolvimento. No entanto, prossegue o autor, em 1982, o Banco Mundial compõe um comitê designado 'Comitê Banco Mundial ONGs' que envolvia administradores seniores do Banco Mundial e 26 líderes de ONGs de diversos lugares do mundo, sendo três quintos provenientes de nações em desenvolvimento. A partir desse momento, o envolvimento entre Banco Mundial e ONGs tem se expandido.

Fernandes (2000, p. 27) sintetiza a questão acerca do surgimento da expressão ONGs com esta passagem:

Por extensão, com a formulação de programas de cooperação internacional para o desenvolvimento estimulados pela ONU, nas décadas de 1960 e 1970, cresceram na Europa ocidental ONGs 
destinadas a promover projetos de desenvolvimento no Terceiro Mundo. Formulando ou buscando projetos em âmbito não-governamental, as ONGs européias procuram parceiros mundo afora $\mathrm{e}$ acabaram por fomentar o surgimento de ONGs nos continentes do hemisfério Sul.

Mesmo que o termo ONG tenha surgido e se disseminado por iniciativa da ONU e do Banco Mundial, sua 'importação' não se deu sem adaptações ao contexto brasileiro. Landim (1993, p. 11) relata esse aspecto como segue: "Mas como várias outras 'importações' que fazem parte habitual da história cultural e política em um contexto nacional como o brasileiro, adaptaram-se e se 'retraduziram' em função de relações e dinâmicas sociais locais". É dentro desse contexto que Falconer (1999, p. 48) afirma ser a identidade das ONGs resultante não apenas do sistema de cooperação internacional e ajuda externa entre nações subdesenvolvidas, como também da institucionalização de movimentos sociais modernos. Landim (1993, p. 13) menciona que foram as organizações de 'assessoria ao movimento popular' as ONGs pioneiras. Mais à frente, Landim (1993, p. 32) sintetiza essa idéia:

[...] as organizações "a serviço dos movimentos populares" foram as primeiras - ou talvez as únicas, de modo mais sistemático - a se auto-identificar, a investir na construção de um conjunto de crenças e concepções sobre o que é ser uma "ONG" no Brasil, a produzir instâncias onde se constituem padrões de legitimidade a esse respeito.

Montaño (2002, p. 138-139), analisando a identificação das ONGs com os movimentos sociais, destaca:

- Efetivamente, [...] surgem fortemente vinculadas aos movimentos sociais desses anos [décadas de 70 e 80], procurando sua melhor organização, participação, articulação nas suas demandas, reivindicações e lutas. Porém, com o advento dos regimes democráticos pós-ditaduras, com a retirada paulatina das agências financeiras internacionais, com o retorno à vida política dos sindicatos e partidos proscritos - particularmente, no Brasil, após a Constituição de 88 -, muitos desses movimentos começam a entrar em crise [...].

- Estas [ONGs] são vistas como menos politizadas, mais empresariais, voltadas para o autofinanciamento ou para a procura de parcerias no sentido de obter fundos, o que lhes exige maior eficiência. Diferenças que, não obstante, confirmariam a tendência de mudança de um tipo de organização (o movimento social) para outra (a ONG), de um tipo de militante para outro.

Landim (1993, p. 145) afirma que o primeiro texto publicado em português utilizando o termo 'ONG' foi escrito por Rubem César Fernandes, sendo apresentado em um seminário latino-americano promovido pela FAO-CMCH (Food and Agriculture Organization Campanha Mundial Contra a Fome), ocorrido no Rio de Janeiro, em julho de 1985.

Portanto, as ONGs - frutos da iniciativa da ONU e do Banco Mundial - passam, no Brasil, na década de 60, a serem consideradas sucessoras dos movimentos sociais. O período no qual surgem é marcado pelo autoritarismo em decorrência do golpe militar ocorrido em 1964, o que lhes imprime caráter contestador frente ao Estado autoritário. 


\subsubsection{Evolução e Principais Características}

Considerando o surgimento das ONGs - contexto mundial, sobretudo na Europa, na década de 40, e contexto da América Latina e África, na década de 60 -, Aristizábal (apud Teodósio, 2003) faz um paralelo entre esses dois grupos, designando, porém, as ONGs de ONGD (Organização Não-Governamental de Desenvolvimento), e as segmentando em dois grandes grupos: ONGDs do Norte e ONGDs do Sul. Em seguida, a autora "[...] destaca a necessidade de compreensão da trajetória histórica dessas organizações e os diferentes matizes ideológicos por detrás das quatro gerações de ONGDs do Norte”. As quatro gerações referidas são estas:

- Primeira Geração ou Assistencialistas: nascidas durante a Segunda Grande Guerra, voltamse a remediar situações de escassez e risco através de ações de emergência e assistência, sendo os únicos atores envolvidos nessas ações;

- Segunda Geração ou Desenvolvimentistas: aparecem nos anos 60, seguindo orientações teórico-metodológicas desenvolvimentistas. Para tanto, pautam-se pela transferência de recursos econômicos e tecnológicos do Norte para o Sul;

- Terceira Geração ou de Parceria e Denúncia Social: seu nascedouro se dá nos anos 70, fortemente marcadas pelo caráter político da ação. As ações de cooperação buscam aumentar a participação política e fortalecer a sociedade civil;

- Quarta Geração ou de "Empoderamento": surgidas nos anos 80, realizam ações através de redes formais e informais de pessoas e organizações, tendo como parâmetro a interdependência social, econômica, política e ecológica, ou como muitos denominam, o chamado Desenvolvimento Local Integrado Sustentável (DLIS).

Quanto às ONGs do Sul, a autora também segmenta-as em quatro categorias básicas:

- ONGs de Ação Direta: inseridas nas comunidades que têm como alvo, atuam diretamente, ou seja, sem intermediários nestas localidades, geralmente em articulação com Organizações de Base (associações de moradores, cooperativas de trabalhadores, dentre outras), desenvolvem via de regra programas no âmbito da assistência social;

- ONGs Intermediárias: encarregam-se de estabelecer relações, contatos e assessoria técnicoadministrativa visando a captação de recursos internacionais e governamentais para projetos em diferentes áreas de atuação [...];

- ONGs de Estudo: formadas por técnicos especializados, em geral desenvolvem análises sobre setores, regiões ou países, trabalhando muitas vezes em assessoria a governos;

- ONGs de Defesa dos Direitos Humanos: formam redes com bases em vários países, sobretudo naqueles que violam sistematicamente direitos humanos.

Korten (apud Kisil, 2000, p. 144), por sua vez, argumenta a existência de três gerações

de ONGs, e apresenta-as como segue:

- Geração um: foram estabelecidas com o objetivo de prestar assistência e bem-estar, em resposta a situações de emergência;

- Geração dois: eram organizações de desenvolvimento local em pequena escala, que foram estabelecidas baseadas na teoria de que a melhoria sustentável no nível dos pobres dependem 
do aumento de sua capacidade em encontrar suas próprias necessidades, com seus próprios recursos; e

- Geração três: são criadas como parte de sistemas sustentáveis de desenvolvimento, nos quais o autodesenvolvimento depende de sistemas que unem organizações públicas e privadas, integrando as iniciativas locais num meio ambiente de apoio para o desenvolvimento.

Thompson (2000, p. 43-44) e outros pesquisadores realizaram estudo envolvendo alguns países da América Latina sobre a origem das ONGs nas décadas de 60 e 70. De forma sintética, pode-se apresentar algumas conclusões referentes a essas entidades:

1. representavam formas de ação política que se opunham ao autoritarismo surgiram em um contexto de regimes militares, possuindo caráter transitório;

2. representavam núcleos de energia social que buscavam favorecer a participação dos excluídos e eram dotadas de forte identificação com setores populares;

3. representavam entidades autônomas com relação ao Estado; e

4. tinham a capacidade de fazer política de uma forma diferente, qual seja, em estreita vinculação com os novos movimentos sociais emergentes.

Surgidas na década de 60 na América Latina, pode-se identificar quatro fases distintas quando se analisa a bibliografia disponível acerca de aspectos históricos envolvendo as ONGs brasileiras. A primeira fase é denominada por Landim (1993, p. 65) de pré-história das ONGs. Nesse período, as ONGs conviveram em seus primeiros anos de existência junto a agentes cristãos, de forma que, conforme a autora, "Os tempos de origem [...], segundo referências no meio, situam-se na segunda metade da década de 60, e neles agentes cristãos de presença discreta, mas ativa na sociedade ocupam o papel principal". Em seguida, Landim (1993, p. 84) sintetiza as características dessas ONGs que reivindicam seu pioneirismo:

Com essa reivindicação buscam valorizar uma tradição "pura", ou "autêntica", da "educação de base popular", cunhada em terrenos da metodologia freiriana e que busca raízes em práticas de leigos cristãos do pré-64. Essa "tradição" dos trabalhos localizados de cunho educativo conviveria, no campo formado por essas entidades, com a opção que se tornaria dominante entre as "ONGs", a de "assessoria aos movimentos populares. Mas isso só na virada dos anos 70/80".

Tachizawa (2002, p. 25), ao interpretar dados relativos ao surgimento das ONGs, afirma que eles revelam que entre as pioneiras estão aquelas que surgem junto "[...] às igrejas cristãs em sua vertente popular, as que se ligam fundamentalmente aos movimentos comunitários, de bairros, de periferia e sindicais". A FASE - Federação de Órgãos para Assistência Social e Educacional, referida por Landim (1993, p. 83-85) como a primeira ONG, fundada em 1961, nasce justamente atuando em obras sociais ligadas à Igreja Católica. Dessa forma, esse período é marcado pelas ONGs pioneiras que atuam junto a movimentos populares por meio de ações educacionais. Landim (1993, p. 47) menciona que essas 
entidades são as que estão mais próximas de um conjunto estruturado, as que mais assumem a condição de ONGs e investem na manutenção dessa condição, "Certamente, esse conjunto de entidades teve o maior peso simbólico, na construção social dessa categoria”. Por outro lado, naquele momento, as ONGs pioneiras ainda não se viam como ONGs, o que só ocorre por volta dos anos 80 .

A segunda fase se inicia na década de 70, período em que já se havia instaurado o regime militar brasileiro (1964-1985). Durante essa fase, tais entidades passam por um processo de mudança de concepção, de forma que agregam às suas atividades de assistência aos movimentos populares uma participação política. Landim (1993, p. 106) apresenta esse aspecto com o seguinte trecho:

Os "Centros/ONGs" vão-se então transformar a partir de um determinado caminho que tira seus agentes de uma relação privilegiada com o campo religioso e da assistência social para os inserir, nos finais da década de 70, no campo de movimentos sociais e sindicais, acompanhando de perto determinadas mudanças de conjuntura no país. Optam por assumir uma certa posição no campo da política (claro, no pólo por onde transita também a Igreja Popular).

Nessa fase, as ONGs passam a se diferenciar dos movimentos de assistência social, ou seja, passam a não apenas ter um trabalho de base, mas também a atuarem politicamente em oposição ao regime autoritário, obtendo, de uma forma geral, recursos provenientes de agências de cooperação internacional. Assim, afirma Landim: “vira 'ONG' quando tem trabalho de base [...] e parcerias internacionais". As parcerias internacionais permitiram às ONGs se tornarem autônomas frente à Igreja e mesmo frente a outros campos sociais cuja atividade era conflitante com a forma de atuação dessas entidades. Arantes (2000, p. 14) relembra a circunstância histórica que fez surgir a sigla ONG no Brasil:

Como se há de recordar, nalgum momento da década de 1970, o novo ímpeto dos chamados movimentos sociais, então em plena ascensão, cruzou o caminho de microorganizações internacionais de cooperação, cujo ânimo prestativo, bem ao feitio do clima de reconstrução mundial característico do pós-guerra, estava aos poucos se deixando contagiar pelo espírito militante das campanhas internacionais em favor dos direitos humanos.

Tachizawa (2002, p. 24) faz o mesmo ao mencionar que, historicamente, as ONGs surgem durante o regime militar “[...] acompanhando um padrão característico da sociedade brasileira, onde o período autoritário convive com a modernização do país e com o surgimento de uma nova sociedade organizada [...]”. Essa nova sociedade está baseada numa busca de autonomia frente ao Estado. Bailey (2000, p. 88) acrescenta que as ONGs começam a se identificar como ONGs durante o período militar, sendo "[...] influenciadas pelo pensamento social progressista e pela teologia da libertação”. 
A terceira fase surge na década de 80 e se estende até metade da década de 90 , período marcado pelo processo de redemocratização que se consolida em 1985 com as Diretas-Já. Nesse momento, conforme Landim (1993, p. 152-153), as ONGs questionam se devem ou não trabalhar com o Estado e, embora reforcem, em resposta, seu caráter autônomo e nãogovernamental, começam a se intensificar parcerias entre ONGs e Estado como conseqüência da diminuição de recursos provenientes das agências de cooperação internacional.

Haddad (2000), Fischer \& Fischer (1994) e Landim (1993) consideram a década de 80 como o período de crescimento das ONGs. Camargo et al (2001, p. 53) afirmam que a partir de 1982 “[...] tivemos um período de grande expansão de ONGs no Brasil, coincidindo com uma fase da vida nacional em que dois elementos se destacam". De um lado, “[...] a reordenação das forças político-sociais em blocos partidários, em luta pelo acesso ao poder [...]", e, do outro, “[...] o discurso e prática efetiva por parte do governo central, em relação a políticas de desestatização". Montaño (2002, p. 224) sugere dois mecanismos que justificam a expansão das ONGs nesse período: 1) mudança de orientação dos doadores internacionais de passarem a destinar recursos diretamente às ONGs e 2) criação de um vasto número de ONGs cujos objetivos são a captação desses recursos (fundraising) e a geração de (auto-)emprego. A Associação Brasileira de Organizações Não-Governamentais (ABONG, 2002b), em pesquisa realizada durante agosto e novembro de 2001 com suas associadas no Brasil, constatou que, quanto à origem, essas entidades seguem a distribuição que consta na Tabela 3:

Tabela 3 - Origem das ONGs - ABONG 2002

\begin{tabular}{|l|c|c|}
\hline & $\mathrm{N}^{\circ}$ de respostas & $\%$ \\
\hline Até 1970 & 10 & 5,1 \\
\hline $1971-1980$ & 26 & 13,3 \\
\hline $1981-1990$ & 96 & 49,0 \\
\hline $1991-2000$ & 64 & 32,6 \\
\hline Total & 196 & 100 \\
\hline
\end{tabular}

Fonte: ABONG (2002b, p. 11).

Percebe-se que praticamente metade das ONGs foi fundada na década de 80 , enquanto que um pouco mais de $18 \%$ foram criadas antes desse período.

Em suma, com o fim do período autoritário, as ONGs se vêem na necessidade de assumir uma nova postura de atuação. Conforme Landim (1993, 152-153):

[...] diante desses novos tempos, as "ONGs" são levadas a desenvolver, ou aprimorar, um discurso sobre as especificidades de sua atuação autônoma, independentemente das mudanças de regime. Por um lado, há as avaliações das limitações e dos vícios da efetiva atuação do Estado brasileiro na área social - as ineficiências, cooptações, fisiologismos, autoritarismos, etc. [...]. 
Por outro lado, essa é a época em que os movimentos sociais - em cuja dinâmica as "ONGs" se desenvolveram e acharam justificativas para sua existência - estão mais consolidados e também se acham permeados pelas lutas de correntes políticas as mais diversas.

Adicionalmente, como menciona Bava (2003, p.54), é na década de 80 que as ONGs começam a se organizar em redes de tal forma que passam a ter "[...] um papel cada vez mais importante e que vão articular, por sua vez, espaços internacionais e nacionais, gerando, por exemplo, esta mesa de articulação de associações nacionais de ONGs da América Latina e gerando a própria possibilidade do Fórum Social Mundial".

Haddad (2000, p. 1), ainda na terceira fase, sentencia que, na década de 90, as ONGs se tornam visíveis e polemizadas. Neder (1998) afirma que as ONGs são descobertas pela mídia brasileira entre a Conferência Mundial sobre Meio Ambiente e Desenvolvimento, ocorrida em 1992, e a fase pré-eleitoral de 1994. Landim (1993, p. 16-17) relata que, no final da década de 80, essas entidades começaram a ser registradas pela imprensa e relaciona eventos importantes do início da década de 90 que contribuíram para essa visibilidade:

- 1991 - Primeiro Encontro Internacional de ONGs e Agências das Nações Unidas;

- fundação em agosto de 1991 da ABONG;

- 1991 - Criação do 'Fórum Brasileiro de ONGs Preparatório para a Conferência da Sociedade Civil sobre Meio Ambiente e Desenvolvimento';

- junho de 1992 - 'Fórum Global', acontecimento que teve por base institucional uma enorme quantidade de entidades designadas como ONGs;

- realização da ECO-92.

Portanto, a terceira fase é marcada por mudanças na forma de atuação das ONGs tendo em vista o fim do período autoritário. Essas entidades reforçam o seu caráter autônomo, mesmo iniciando projetos de colaboração com o Estado. Como conseqüência desse período, as ONGs, antes concentradas em apoio a movimentos populares, diversificam sua área de atuação. Fonseca (2000) destaca esse aspecto de diversificação ao apresentar as várias áreas em que tais entidades podem atuar, a saber:

[...] saúde, educação e cultura, ecologia, movimento dos sem-terra, defesa de grupos minoritários, associações profissionais e/ou voluntárias, entidades de classe, fundações privadas, instituições filantrópicas, movimentos sociais organizados, outras organizações assistenciais ou caritativas da sociedade civil e muitos outros [...].

Landim (1993, p. 32), ao considerar que o termo 'ONG', por definição, já traz consigo a possibilidade de usos diferenciados, afirma que essas entidades agregaram organizações que foram além das de 'assessoria ao movimento popular' e que atuavam junto a temas 
específicos, tais como: negros, mulheres, índios, meninos, AIDS, ecologia, deficientes físicos etc. A ABONG constatou, por meio de respostas múltiplas, que as principais áreas temáticas de atuação de suas associadas são as que constam na Tabela 4.

Tabela 4 - Principais áreas temáticas de atuação das ONGs - ABONG 2002

\begin{tabular}{|l|c|c|}
\hline Principais áreas temáticas de atuação & $\mathrm{N}^{\circ}$ de respostas & $\%$ \\
\hline Educação & 102 & 52,04 \\
\hline Organização popular/participação popular & 75 & 38,27 \\
\hline Justiça e promoção de direitos & 72 & 36,73 \\
\hline Fortalecimento de outras ONGs/Mov. Populares & 51 & 26,02 \\
\hline Relação de gênero e discriminação sexual & 49 & 25,00 \\
\hline Saúde & 48 & 24,49 \\
\hline Meio Ambiente & 37 & 18,88 \\
\hline Trabalho e renda & 36 & 18,37 \\
\hline DST/AIDS & 21 & 10,71 \\
\hline Questões urbanas & 21 & 10,71 \\
\hline Arte e cultura & 19 & 9,69 \\
\hline Comunicação & 19 & 9,69 \\
\hline Agricultura & 18 & 9,18 \\
\hline Orçamento público & 16 & 8,16 \\
\hline Assistência social & 15 & 7,65 \\
\hline Desenvolvimento da economia regional & 13 & 6,63 \\
\hline Questões agrárias & 13 & 6,63 \\
\hline Discriminação racial & 11 & 5,61 \\
\hline Segurança pública & 6 & 3,06 \\
\hline Outros & 18 & 9,18 \\
\hline Não sabe/não respondeu & 2 & 1,02 \\
\hline Fonte: ABONG (2002b, p. 12) & & \\
\hline
\end{tabular}

Nota-se que, apesar da diversificação referida, as principais áreas de atuação ainda são a de educação e outras que refletem a atuação junto a entidades de base e movimentos populares, ou seja, refletem o contexto histórico no qual essas entidades surgiram - centros de educação que atuam junto aos movimentos populares.

A quarta fase tem início na segunda metade da década de 90, quando os questionamentos acerca da forma de atuação do Estado começam a ficar mais intensos, o que vem, conseqüentemente, afetar a forma de atuação das ONGs. Haddad (2000, p. 1) considera que, com a chegada do ano 2000, passa-se a questionar qual a verdadeira natureza e significado das ONGs. Tal questionamento está relacionado às mudanças ocorridas na forma de atuação dessas entidades. Assim, o autor apresenta os dois extremos de atuação das ONGs ao mostrar que essas entidades "Para alguns, são motores de transformação social, uma nova forma de fazer política. Para outros, um campo propício às ações do neoliberalismo, que busca repassar suas responsabilidades sociais para o campo da sociedade civil”. Oliveira (2000, p. 40) é da opinião que o papel das ONGs na luta contra a pobreza é: 
[...] fazer política, publicizar os conflitos, armar os interlocutores sociais de argumentos, de diagnósticos das carências, de denúncia das graves lacunas e de estudar, com o maior rigor técnico possível, para inscrever-se no próprio terreno da racionalidade instrumental do governo, do empresariado e da mídia, no terreno da competência, as proposições que, movidas por uma racionalidade de valores, sejam capazes de disputar os significados da política.

Por outro lado, Montaño (2002, p. 19), tratando o Terceiro Setor como um todo, considera que:

O conjunto de organizações e atividades que compreende o chamado 'Terceiro Setor', para além dos eventuais objetivos manifestos de algumas organizações ou da boa intenção que move o ator solidário e voluntário singular, termina por ser instrumentalizado, pelo Estado e pelo capital, no processo de reestruturação neoliberal, particularmente no que refere à formulação de uma nova modalidade de trato à 'questão social', revertendo qualquer ganho histórico dos trabalhadores nos seus direitos de cidadania.

Sintetizando, Haddad (2000, p. 1-2) sugere que, ao se considerar o universo total de ONGs, pode-se encontrar entidades em qualquer desses dois extremos, e mesmo, em outras posições que possam existir entre esses extremos. No entanto, segundo Bava (2003, p. 56), nesse novo contexto social, "O principal desafio que a cidadania e essas redes têm a enfrentar, na politização do social, é desnaturalizar a pobreza e a exclusão social".

Apesar das diferenças existentes entre as formas de atuação, um ponto comum entre as ONGs é o de possuírem finalidades, que em última instância, podem ser resumidas na contribuição para o desenvolvimento social de uma comunidade, quer seja local, regional, nacional ou mesmo internacional, através de serviços sociais. A Tabela 5 apresenta o âmbito de atuação dessas entidades por estado.

Tabela 5 - Âmbito de atuação por estado - ABONG 2002

\begin{tabular}{|l|c|c|l|c|c|}
\hline Estado & $\mathbf{N}^{\mathbf{0}}$ de respostas & $\mathbf{\%}$ & Estado & $\mathbf{N}^{\mathbf{0}}$ de respostas & $\mathbf{\%}$ \\
\hline São Paulo & 84 & 42,86 & Mato Grosso & 28 & 14,29 \\
\hline Rio de Janeiro & 63 & 32,14 & Rio Grande do Sul & 27 & 13,78 \\
\hline Paraíba & 56 & 28,57 & Sergipe & 27 & 13,78 \\
\hline Pernambuco & 50 & 25,51 & Goiás & 25 & 12,76 \\
\hline Santa Catarina & 47 & 23,98 & Rio Grande do Norte & 25 & 12,76 \\
\hline Tocantins & 47 & 23,86 & Amazônia & 23 & 11,73 \\
\hline Bahia & 44 & 22,45 & Alagoas & 22 & 11,22 \\
\hline Pará & 41 & 20,92 & Mato Grosso do Sul & 22 & 11,22 \\
\hline Ceará & 38 & 19,39 & Acre & 20 & 10,20 \\
\hline Minas Gerais & 36 & 18,37 & Piauí & 20 & 10,20 \\
\hline Maranhão & 33 & 16,84 & Amapá & 19 & 9,69 \\
\hline Distrito Federal & 30 & 15,31 & Rondônia & 16 & 8,16 \\
\hline Espírito Santo & 29 & 14,80 & Roraima & 13 & 6,63 \\
\hline Paraná & 29 & 14,80 & Não sabe/não respondeu & 15 & 7,65 \\
\hline
\end{tabular}

Fonte: ABONG (2002b, p. 10).

$\mathrm{Na}$ análise da Tabela 5, São Paulo é o estado onde as ONGs atuam de forma mais expressiva, o que não ocorre nos estados da Região Norte em que elas são pouco atuantes. 


\subsubsection{Desafios Atuais}

Considerando o contexto atual, identificam-se novos desafios enfrentados pelas ONGs. Tenório (2001, p. 14), por exemplo, enumera os principais pelos quais passaram essas entidades na década de 90 :

- $\quad$ sair do micro para o macro, isto é, não limitar suas ações a microregiões, e sim contribuir com sua experiência para o desenvolvimento macro;

- sair do privado para o público, deixando de atuar na clandestinidade para atuar de forma mais transparente, divulgando ao público o que são, por que lutam, o que propõem; e

- passar da resistência à proposta, ou seja, da ação contra o Estado e à margem do mercado para uma ação participante.

Adicionalmente, Tenório (2001, p. 14) afirma que as ONGs brasileiras passam por um momento de dificuldades quanto à obtenção de recursos. Tachizawa (2002, p. 180) reforça esse aspecto ao afirmar que uma das tendências das ONGs é a preocupação crescente com a sustentabilidade. Inicialmente, quando nem se autodenominavam ONGs, eram mantidas pela Igreja; passando, em seguida, a receber recursos de agências internacionais de cooperação as quais, atualmente, permanecem como as principais financiadoras das atividades dessas entidades, o que pode ser percebido por meio da Tabela 6.

Tabela 6 - Fontes de financiamentos das ONGs - ABONG 2002

\begin{tabular}{|l|c|c|c|}
\hline Fontes de Financiamentos & $\mathbf{1 9 9 7}$ & \multicolumn{2}{|c|}{$\mathbf{2 0 0 0}$} \\
\hline & $\mathbf{\%}$ & $\mathbf{N}^{\mathbf{0}}$ de respostas & \% \\
\hline Agências internacionais de cooperação & 81,11 & 154 & 78,57 \\
\hline Comercialização de produtos e venda de serviços & 45,56 & 91 & 46,43 \\
\hline Órgãos governamentais federais & - & 89 & 45,41 \\
\hline Outras fontes de financiamento & 40,56 & 73 & 37,24 \\
\hline Empresas, fundações ou institutos empresariais brasileiros & 22,22 & 64 & 32,65 \\
\hline Órgãos governamentais estaduais & 47,78 & 64 & 32,65 \\
\hline Contribuições associativas & - & 51 & 26,02 \\
\hline Órgãos governamentais municipais & - & 44 & 22,45 \\
\hline Agências multilaterais e bilaterais & 26,67 & 12 & 12,24 \\
\hline Doações individuais & - & 24 & 12,24 \\
\hline Não sabe/não respondeu & 1,67 & 8 & 4,08 \\
\hline
\end{tabular}

Fonte: ABONG (2002b, p. 16).

Portanto, quase $79 \%$ das fontes de financiamento das ONGs são provenientes de agências internacionais de cooperação. Um ponto interessante é a percentagem de ONGs que utilizam a comercialização de produtos e venda de serviços para a obtenção de recursos. Em 1997, essas entidades não possuíam qualquer fonte de financiamento provenientes de órgãos governamentais federais ou municipais, fato que mudou bastante, considerando-se que, em 
2000, os órgãos governamentais federais são a terceira fonte de financiamento mais utilizada.

Nota-se ainda que as doações individuais permanecem inexpressivas, pois apenas $12,24 \%$ das ONGs obtêm recursos por meio dessa fonte.

Analisando por um outro ponto de vista a questão das fontes de financiamento das ONGs, a Tabela 7 apresenta a proporção de cada fonte em relação ao orçamento total.

Tabela 7 - Fontes de financiamento e sua proporção no orçamento total - ABONG 2002

\begin{tabular}{|l|c|c|c|c|}
\hline Fontes de financiamento & Número & Valor do & \% sobre orçamento total \\
\cline { 3 - 5 } & de ONGs & orçamento R\$ & $\mathbf{2 0 0 0}$ & $\mathbf{1 9 9 3}$ \\
\hline Agências internacionais de cooperação & 116 & $70.182 .947,73$ & 50,61 & 75,9 \\
\hline Órgãos governamentais federais & 63 & $10.404 .145,74$ & 7,50 & - \\
\hline Órgãos governamentais estaduais & 38 & $8.227 .083,58$ & 5,93 & 3,2 \\
\hline Órgãos governamentais municipais & 28 & $6.978 .721,08$ & 5,03 & - \\
\hline Empr, fund. ou instit. empresariais brasileiros & 43 & $5.806 .643,74$ & 4,19 & 1,8 \\
\hline Outras fontes de financiamento & 52 & $5.528 .660,75$ & 3,99 & 5,0 \\
\hline Comercialização de produtos e venda de serviços & 71 & $5.313 .436,52$ & 3,83 & 6,9 \\
\hline Agências multilaterais e bilaterais & 17 & $3.324 .057,56$ & 2,40 & 7,0 \\
\hline Contribuições associativas & 38 & $2.458 .266,03$ & 1,77 & - \\
\hline Valor não especificado por fonte & & $20.435 .898,43$ & 14,74 & - \\
\hline Total & & $138.659 .861,16$ & 100,00 & 100,00 \\
\hline
\end{tabular}

Fonte: ABONG (2002b, p. 17)

Percebe-se que a proporção de recursos de agências internacionais de cooperação é superior à soma das demais fontes de financiamentos. Essa situação era mais marcante em 1993 quando mais de 75\% eram provenientes de agências internacionais. Portanto, esses dados mostram que, mesmo permanecendo a principal fonte de financiamento das ONGs, tanto no que se refere ao número de entidades que a utilizam, quanto na proporção desses recursos em relação ao seu volume total, o montante proveniente das agências internacionais de cooperação vem diminuindo. Tenório (2001, p. 14) menciona que essas agências estão se direcionando para regiões mais necessitadas, como África e Leste Europeu. Landim (1993, p. 153) apresenta depoimento de um dirigente de ONG que destaca esse aspecto: "O dinheiro vinha com facilidade por causa da ditadura; com a democratização, as coisas tinham que ser melhor definidas".

Essa tendência justifica, assim, a busca crescente de recursos por outros meios, como, por exemplo, o Estado e as empresas. Como afirma Roesch (2002), as ONGs, atualmente, "[...] sofrem pressões para buscar novas formas de sustentação financeira e reduzir sua dependência das agências financiadoras internacionais [...], e, para tanto, têm necessidade de fortalecer relações com outros organismos privados ou estatais". Em especial, a relação com o Estado torna-se facilitada em decorrência das possibilidades que ele propicia. Assim, tem sido 
crescente a busca de parcerias entre Estado e ONGs, como forma de essas entidades obterem recursos e o Estado descentralizar a prestação dos serviços sociais.

Um segundo desafio para as ONGs é justificar os recursos aplicados para a realização de serviços sociais. Bailey (2000, p. 99) destaca que essas entidades precisam demonstrar que são ao mesmo tempo eficientes e efetivas "[...] no uso do tempo e do dinheiro de seus membros, do público em geral ou das instituições”. Seguindo, Bailey considera que, para tanto, é necessário melhorar a qualificação tanto do pessoal quanto dos sistemas gerenciais. São, portanto, dois outros desafios que enfrentam as ONGs. Analisando a Tabela 8 em que se apresenta o número de pessoas ocupadas nessas entidades segundo o nível de escolaridade, percebe-se que aproximadamente $60 \%$ dos colaboradores possuem curso superior e nível de pós-graduação - completo ou incompleto, percentual indicativo da existência de pessoal qualificado nessas entidades.

Tabela 8 - Número de pessoas ocupadas segundo o nível de escolaridade - ABONG 2002

\begin{tabular}{|l|c|c|}
\hline & $\mathbf{N}^{\mathbf{0}}$ de respostas & \% \\
\hline Nível primário (completo ou incompleto) & 203 & 4,56 \\
\hline Nível ginásio (completo ou incompleto) & 297 & 6,68 \\
\hline Nível médio (completo ou incompleto) & 1.142 & 25,67 \\
\hline Nível superior (completo ou incompleto) & 2.086 & 46,89 \\
\hline Nível pós-graduação & 527 & 11,85 \\
\hline Outros & 194 & 4,36 \\
\hline Total & 4.269 & 100 \\
\hline
\end{tabular}

Fonte: ABONG (2002b, p. 20).

A questão dos sistemas gerenciais não pode ser analisada de forma isolada, pois sua análise é mais bem realizada quando dentro do contexto da gestão organizacional. Como afirma Tenório (2001, p. 15), “[...] as ONGs têm que pensar em acrescentar às suas peculiaridades novos instrumentos de gestão, dotando seus quadros de habilidades, conhecimentos e atitudes que assegurem, ao fim e ao cabo, o cumprimento dos objetivos institucionais". Coelho (2002, p. 121) por sua vez, afirma:

Uma boa gestão é fundamental para melhorar a qualidade dos serviços. Por outro lado, cada vez mais as entidades (em grande medida as ONGs e em menor proporção as associações) estão preocupadas em planejar sua atuação a longo prazo, de forma a se precaver de mudanças conjunturais.

As ONGs que até então deram pouca atenção a aspectos da gestão organizacional, passam a utilizar conceitos da administração como forma de tornar mais eficiente a utilização dos recursos a elas destinados, com a intenção não apenas de justificar a captação desses recursos junto às entidades financiadoras, como também de aumentar o volume de tais 
recursos. Considera-se que as ONGs precisam aperfeiçoar seus processos de gestão como forma de obter resultados mais eficientes e eficazes na prestação de seus serviços e, portanto, na realização de seus objetivos sociais. Falconer (1999, p. 109), tratando como um todo o setor formado pelas entidades sem fins lucrativos, enfatiza tal situação com esta afirmação:

Há um virtual consenso entre estudiosos e pessoas envolvidas no cotidiano de organizações sem fins lucrativos de que, no Brasil, a deficiência no gerenciamento destas organizações é um dos maiores problemas do setor, e que o aperfeiçoamento da gestão - através da aprendizagem e da aplicação de técnicas oriundas do campo de Administração - é um caminho necessário para o atingir de melhores resultados.

Nota-se que um dos problemas fundamentais do Terceiro Setor - de forma geral - e das ONGs - em particular - é de gestão. Tal fato vem provocando o surgimento de vários programas acadêmicos de capacitação profissional direcionados àqueles que colaboram ou desejam atuar em entidades dessa natureza. Na mesma linha, Roesch (2002) afirma que "A gestão das organizações não-governamentais passou a despertar interesse nos meios acadêmicos nos últimos anos, tendo em vista o crescimento e a diversificação do setor e as mudanças organizacionais observadas nestas instituições”. No entanto, continua essa autora, “[...] pouco se sabe sobre as práticas de gestão destas organizações no Brasil”. Um dos motivos da escassez de pesquisas empíricas acerca da gestão de ONGs, na opinião dessa autora, decorre do fato "[...] de que estas organizações exercem diferentes papéis e há dificuldades conceituais para defini-las e comparar suas práticas".

De forma semelhante, Williams (1990), ao tratar especificamente das ONGs internacionais, destaca que tais entidades possuem limitações quanto à área administrativa e sua capacidade de treinar o staff local. Frumkim \& Kim (2000) ressaltam que um melhor gerenciamento tem sido visto não apenas como uma maneira de elevar a eficácia organizacional da entidade, mas também de ser um método de redução de custos.

Tal fato tem propiciado diversas propostas de ações para que entidades sem fins lucrativos melhorem suas capacidades de gestão. Alguns autores indicam a utilização dos princípios tradicionais de administração, como o faz Tenório (2001) ao propor a aplicação dos quatro princípios administrativos clássicos - planejamento, organização, direção e controle.

Outros autores, no entanto, sugerem uma adaptação desses princípios às especificidades existentes nessas entidades, ou seja, a existência de um processo de gestão específico para ONGs. Assim o faz Falconer (1999) que destaca quatro dimensões que precisariam ser consideradas no desenvolvimento da gestão de todas as entidades que compõem o Terceiro Setor: 1) stakeholder accountability, ou seja, necessidade de 
transparência e cumprimento da responsabilidade da organização em prestar contas àqueles que possuem interesses legítimos sobre ela; 2) sustentabilidade, em referência à capacidade da organização na captação de recursos; 3) qualidade de serviços; e 4) capacidade de articulação através de parcerias, alianças, redes ou coalizões.

O’Neill destaca oito distinções que diferenciariam entidades do Terceiro Setor dos demais tipos de organização e que deveriam ser considerados quando do gerenciamento de tais entidades, que são: 1) missão/propósito; 2) valores; 3) aquisição de recursos; 4) resultado; 5) ambiente legal; 6) perfil do trabalhador; 7) governança; e 8) complexidade organizacional (apud FALCONER, 1999). Marçon \& Escrivão Filho (2001) destacam a necessidade em “[...] ampliar o espaço da Teoria das Organizações de forma a reconhecer a gestão das organizações do terceiro setor como peculiar e merecedora de um modelo autônomo".

Independentemente da solução a se propor para a gestão das ONGs, tem-se em consideração que essa não pode limitar a capacidade da entidade em atingir suas metas. Para Tachizawa (2002, p. 149) um modelo de gestão para ONGs é aquele que:

- identifique as estratégias genéricas aplicáveis a esse tipo de organização;

- hierarquize as decisões que compõem o processo de gerenciamento em estratégias e operacionais;

- identifique os diferentes agentes e institucionais que se integram à ONG.

Concluindo, as Organizações Não-Governamentais passam por um desafio: a gestão organizacional. Elas precisam ser eficientes e eficazes na utilização de recursos financeiros, materiais e humanos que lhes são disponibilizados. A superação dos demais desafios sustentabilidade, qualificação do pessoal etc. - depende, em grande parte, de uma gestão organizacional que permita à entidade atingir seus objetivos com o menor volume de recursos. No entanto, antes de propor quais instrumentos de gestão deveria uma ONG aplicar à sua realidade, torna-se necessário reconhecer tal realidade. Em outras palavras, é preciso identificar os parâmetros de design e os fatores situacionais predominantes e determinantes das estruturas organizacionais das ONGs. O capítulo seguinte trata justamente das abordagens organizacionais, dos tipos de estruturas organizacionais e, por fim, da análise de estudos empíricos acerca da estrutura organizacional de ONGs. 


\section{TEORIAS ORGANIZACIONAIS E TIPOLOGIAS DE ESTRUTURAS ORGANIZACIONAIS}

Dentre as diversas abordagens organizacionais desenvolvidas, destaca-se a da configuração das estruturas organizacionais, tendo Henry Mintzberg como um de seus principais estudiosos. Essa considera que uma entidade - seja qual for seu objetivo - tende a ser eficaz quando sua estrutura organizacional é determinada pela consistência entre parâmetros de design e fatores situacionais. No entanto, na literatura específica, são poucas as abordagens organizacionais direcionadas para ONGs.

O presente capítulo tem por objetivo descrever os aspectos básicos de uma entidade, ou seja, seus parâmetros de design e fatores situacionais. Através da compreensão de tais aspectos é possível entender as principais características organizacionais de cada configuração proposta por Mintzberg.

Para tanto, o capítulo está dividido em quatro tópicos principais: definição de organização e de estrutura organizacional, com destaque para a relação da eficácia com essa estrutura; relação das principais abordagens organizacionais, com foco na configuração do design organizacional; apresentação dos tipos de arranjos organizacionais encontrados na literatura pesquisada, com ênfase na tipologia da configuração das estruturas organizacionais; e, por fim, análise de estudos empíricos acerca de arranjos organizacionais, seja para entidades do Terceiro Setor, de uma forma geral, seja especificamente para ONGs.

\subsection{Organização e Estrutura Organizacional}

Antes de se buscar aspectos evolucionários acerca das abordagens organizacionais, procura-se a compreensão do que essas significam, assim como o significado de estrutura organizacional. Para Etzione (1976, p. 11) organizações são “[...] unidades planejadas, intencionalmente estruturadas com o propósito de atingir objetivos específicos". Bernardes \& Marcondes (2003, p. 14) definem organização como uma coletividade de pessoas que tem por função não apenas fornecer bens e serviços à sociedade, mas também atender necessidades de seus colaboradores dentro de uma estrutura em que os indivíduos se relacionam.

Blau \& Scott (1970, p. 16-17) distinguem organizações formais das demais organizações sociais. Para esses autores as organizações sociais, de uma forma geral, apresentam duas dimensões: 1) a estrutura das relações sociais em um grupo ou coletividade maior de pessoas e 2) as crenças e orientações compartilhadas que unem os membros da 
coletividade e guiam sua conduta. No entanto, somente as organizações formais são estabelecidas "[...] com o propósito explícito de conseguir certas finalidades [...]".

Maximiano (1989, p. 21) apresenta duas importantes características que diferenciam uma organização dos demais tipos sociais: 1) divisão do trabalho - “[...] cada pessoa ou grupo de pessoas tem um papel específico que contribui para o objetivo final” e 2) coordenação "[...] os diversos papéis específicos combinam-se e integram-se de modo a convergir para os objetivos comuns". Gibson et al (1988, p. 24) destacam duas principais justificativas para a existência das organizações. A primeira delas é que determinadas metas - obter lucro, prestar serviços sociais etc. - só são alcançáveis mediante a coordenação de um grupo de pessoas. A segunda justificativa é que as organizações, já que nelas as pessoas passam o maior tempo de suas vidas, possuem forte influência sobre o comportamento humano.

O conceito de estrutura organizacional surge das características de organização. Simeray (1977, p. 4) afirma que enquanto a organização está relacionada a um conjunto de meios materiais e humanos, a estrutura está, de forma mais específica, relacionada às pessoas em suas relações de interdependência. Simeray (1977, p. 5) define a estrutura como "[...] um conjunto de pessoas reunidas por uma rede de ligações de dependência ou de cooperação, constituindo inicialmente grupos elementares que se integram em uma sucessão de conjuntos mais complexos, o último dos quais constituirá a empresa em si mesma”.

Maximiano (1989, p. 153-154) define estrutura organizacional como o "[...] produto das decisões de divisão e coordenação do trabalho [...]”. Na opinião do autor, a estrutura “[...] define não apenas as atribuições específicas, mas também o modo como devem estar interligados os diversos grupos especializados, chamados departamentos". Adicionalmente, Vasconcelos \& Hemsley (1989, p. 3) definem estrutura organizacional como segue:

[...] o resultado de um processo através do qual a autoridade é distribuída, as atividades desde os níveis mais baixos até a Alta Administração são especificadas e um sistema de comunicação é delineado permitindo que as pessoas realizem as atividades e exerçam a autoridade que lhes compete para o atingimento dos objetivos organizacionais.

Pugh et al (apud Cohen et al) consideram que a estrutura organizacional está bastante relacionada com o contexto no qual ela funciona, de forma que, muitas de suas variáveis devem ser explicadas por fatores contextuais ou situacionais. Continuando, esses autores incluem, entre os fatores contextuais, o tipo, a tecnologia utilizada, a função social, e a interdependência da organização com outras organizações, e ressaltam que esses fatores têm sido considerados como de importância primária na determinação da estrutura e funcionamento de uma organização. Mintzberg (2003, p. 12) define a estrutura de uma 
organização como “[...] a soma total das maneiras pelas quais o trabalho é dividido em tarefas distintas e, depois, como a coordenação é realizada entre essas tarefas".

Maximiano (1989, p. 171) enumera um conjunto de fatores que deveriam ser considerados na seleção do padrão estrutural mais apropriado para a organização:

- Diversidade ou homogeneidade de operações em decorrência da tecnologia empregada, em relação, por exemplo, à matéria-prima e produção;

- Diversidade ou homogeneidade dos canais de distribuição, das fontes de recursos e das necessidades do consumidor ou usuário;

- Natureza da organização (pública ou privada, banco sindicato, escola etc.) e seus objetivos;

- Ênfase estratégica (estabilidade e eficiência ou expansão e eficácia);

- Diferença entre rotina e inovação. A ênfase em uma ou outra exige diferentes soluções estruturais;

- Taxa de mudança ambiental - estabilidade ou instabilidade no comportamento dos clientes, fornecedores e outros segmentos do ambiente organizacional;

- Participação de cada um dos produtos e serviços ou linhas no volume total de recursos empregados ou resultados obtidos pela empresa;

- $\quad$ Ênfase da administração superior na centralização ou descentralização de autoridade e atividades.

$\mathrm{Na}$ determinação da estrutura organizacional a ser adotada por uma entidade sem fins lucrativos, Rodrigues (2004, p. 138) menciona três pontos que precisam ser considerados: 1) uma clara definição dos conceitos organizacionais de base - missão, visão e objetivos; 2) uma análise do perfil de liderança presente e futuro; e 3) uma implantação da estrutura desejada dentro de uma velocidade capaz de permitir uma adequada reação às mudanças e de possibilitar um uso eficiente dos recursos.

\subsection{Evolução das Teorias do Design Organizacional}

De posse das definições de organização, no sentido formal expresso por Blau \& Scott, e de estrutura organizacional, parte-se para as abordagens organizacionais que buscam fazer com que a entidade se estruture de forma eficaz. Nesse sentido, buscar-se-á uma linha evolucionária que permita uma compreensão de como as abordagens foram propostas.

É certo que desde as primeiras civilizações as organizações buscaram formas eficazes de se organizar. George Jr. (1974) descreve como a administração foi utilizada nas civilizações antigas e chega a afirmar que essas civilizações, em muitos aspectos, eram, provavelmente, tão complexas quanto a que possuímos atualmente. No entanto, como sentenciam Bateman \& Snell (1998, p. 47), “Através da história [...] a maioria dos administradores operou estritamente numa base de tentativa e erro". Essa situação, conforme os autores, modificou-se com a Revolução Industrial, o que mostra a inexistência de uma sistematização do conhecimento administrativo até então. 
A primeira abordagem organizacional sistematizada - Abordagem Clássica - surge durante o período da Revolução Industrial. Maximiano (1989, p. 36) menciona que a Abordagem Clássica “[...] é o nome que se dá a um grupo de pessoas cujas figuras principais foram Frederik Taylor e Henri Fayol, de um lado, e Max Weber de outro", cada um deles está relacionado a uma vertente da Abordagem Clássica. Os dois primeiros com a Administração Científica e a Teoria Clássica, respectivamente, e o terceiro com a Teoria Burocrática. A ênfase da Administração Científica volta-se para as tarefas, enquanto a da Teoria Clássica e da Teoria Burocrática recai sobre a estrutura, tal como consta na Figura 2.

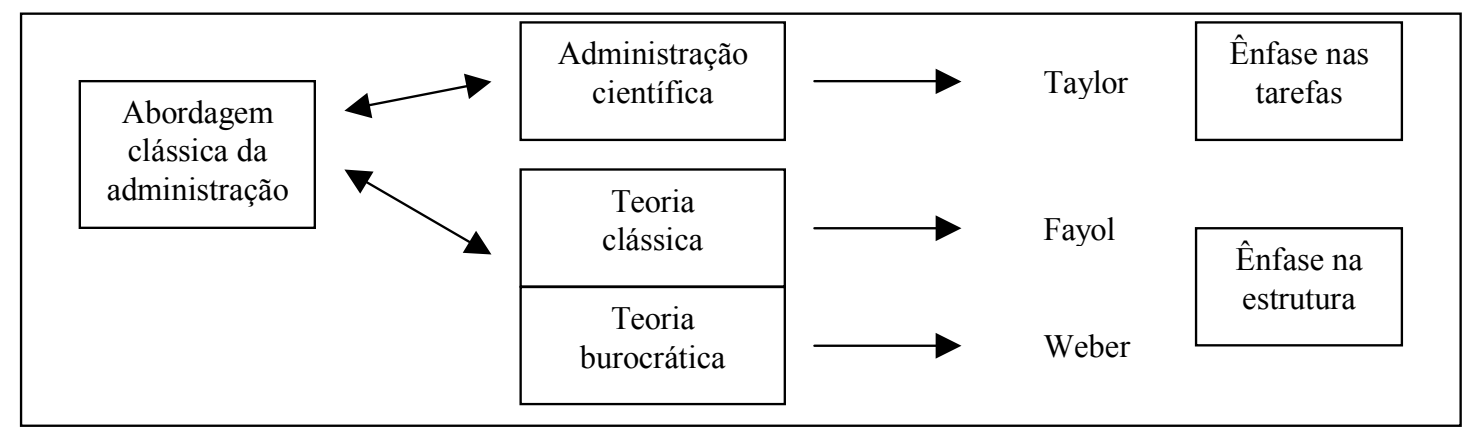

Figura 2 - Abordagens clássicas da administração

Fonte: Adaptado de Chiavenato (1986, p. 61).

Taylor, precursor da Administração Científica, defende cinco princípios que devem ser seguidos dentro da organização e que enfatizam as tarefas: 1) deslocar a responsabilidade pela organização do trabalhador para o administrador; 2) usar métodos científicos para fixar a forma mais eficiente de fazer o trabalho; 3) selecionar a melhor pessoa para desempenhar o trabalho designado; 4) treinar o trabalhador para fazer o trabalho de forma eficiente; e 5) monitorar a performance do trabalhador para garantir que procedimentos apropriados de trabalho são seguidos e que resultados apropriados são alcançados (MORGAN, 1996).

No que se refere à Teoria Clássica, Gibson et al (1988, p. 275-276) mencionam que Fayol sugeriu 14 princípios sem, no entanto, determinar a importância que possuem ou mesmo como se inter-relacionam. Esses princípios foram classificados pelos autores em três tipos diferentes. O Quadro 3 apresenta a referida classificação.

\section{Quadro 3 - Classificação dos princípios de Fayol}

\begin{tabular}{|l|l|l|}
\hline \multicolumn{1}{|c|}{ Princípios Estruturais } & \multicolumn{1}{|c|}{ Princípios de Processo } & \multicolumn{1}{c|}{ Princípios de Resultado Final } \\
\hline Divisão do trabalho & Eqüidade & Ordem \\
Unidade de direção & Disciplina & Estabilidade \\
Centralização & Remuneração do pessoal & Iniciativa \\
Autoridade e responsabilidade & Unidade de comando & 'Espírito de grupo' \\
Cadeia escalar & Subordinação ao interesse geral & \\
\hline
\end{tabular}
Fonte: Gibson et al (1988, p. 275). 
Quanto à Teoria Burocrática, Motta (1985, p. 7) menciona que o termo 'burocracia':

[...] tem sido utilizado em vários sentidos. Tem sido usado para designar uma administração racional e eficiente, para designar o seu contrário, para designar o governo de altos funcionários, para designar organização. Na realidade burocracia é tudo isto, na medida que burocracia é poder, controle e alienação.

Embora afirme não haver na obra de Max Weber qualquer definição de burocracia, Motta (1985, p. 63-64) apresenta as características enumeradas por Weber que refletem os três aspectos centrais da concepção de burocracia desse pensador, quais sejam: formalismo, impessoalidade e profisssionalismo. As referidas características são estas:

1. Um regulamento administrativo que fixa atribuições oficiais, onde está incluída rigorosamente a definição de como se distribuem atividades e deveres, de como se delimita autoridade e de como se dá o processo de nomeação de funcionários;

2. Uma hierarquia de mando e subordinação, onde os postos superiores exercem rigorosa supervisão sobre os inferiores;

3. A administração dos cargos diversos baseia-se na existência de documentos escritos, que constituem arquivos, estando em princípio funcionários e arquivos, bem como todas as atividades, separadas da vida e do domicílio privados do funcionário;

4. Um treinamento especializado e completo para desempenho de diversas atividades administrativas agrupadas em esferas de competência formalmente definidas, caracterizando um aprendizado profissionalizante;

5. O desempenho da administração como única (ou pelo menos principal) atividade, sendo claramente delimitados os horários em que os burocratas permanecem na repartição ou escritório;

6. O conhecimento técnico, por parte dos burocratas, das próprias regras que determinam o desempenho do cargo.

O ponto comum entre essas três teorias organizacionais agrupadas dentro da Abordagem Clássica é, nas palavras de Gibson et al (1988, p. 280), “[...] o reconhecimento da divisão do trabalho como meio adequado de realizar as tarefas”. Dentro dessa abordagem, Morgan (1996, p. 36) destaca que a organização é uma imagem racional, de processo técnico, atuação mecânica, em que os aspectos humanos são menos importantes e se negligencia a existência de tarefas mais complexas e de difícil execução por máquinas.

Nesse sentido, as abordagens clássicas privilegiam aspectos internos da organização, ou seja, seus princípios ignoram fatores situacionais, em especial, o ambiente no qual a organização se encontra, e procuram fazer com que os trabalhadores executem tarefas como se fossem máquinas. Adicionalmente, destaca Chiavenato (1986, p. 105), consideram a administração um processo de planejamento, organização, comando, coordenação e controle.

Decorrente das críticas às teorias da abordagem clássica em que se equiparam homens a máquinas, surge uma segunda abordagem organizacional, a saber: Abordagem Humanística. Maximiano (1989, p. 37) afirma que "Enquanto as contribuições da escola clássica relacionam-se com os aspectos formais das organizações e da administração, a escola das 
relações humanas orienta-se para os aspectos humanos". Chiavenato (1986, p. 134) afirma que, com essa abordagem, a ênfase antes colocada sobre as tarefas, no que se refere à Administração Científica, e na estrutura, no caso da Teoria Clássica e da Teoria da Burocracia, passa a recair sobre as pessoas que participam da organização. Bateman \& Snell (1998, p. 53) mencionam que a abordagem das relações humanas, desenvolvida no início da década de 30, “[...] visava entender como os processos psicológicos e sociais interagem com a situação de trabalho para influenciar o desempenho".

Elton Mayo destaca-se dentro dessa abordagem. Segundo George Jr. (1974, p. 193), "[...] a idéia de Mayo era que os fatores lógicos tinham muito menos importância do que os fatores emocionais na determinação da eficiência produtiva”. Mayo coordenou uma importante experiência que buscou determinar a relação entre 'intensidade da iluminação' e 'eficiência dos operários', referenciada como experiência de Hawthorne cujas conclusões foram apresentadas por Chiavenato (1986, p. 166-169):

1. o nível de produção era determinado por normas sociais e expectativas;

2. o comportamento do indivíduo se apóia totalmente no grupo;

3. o comportamento dos trabalhadores está condicionado a normas e padrões sociais;

4. a empresa passou a ser visualizada como uma organização social composta de diversos grupos sociais informais;

5. os indivíduos dentro da organização participam de grupos sociais e mantêm-se em constante interação social;

6. a maior especialização não é a forma mais eficiente de divisão do trabalho;

7. elementos emocionais, não planejados e mesmo irracionais do comportamento humano, passam a merecer um aspecto especial.

Uma das principais decorrências da Abordagem das Relações Humanas foi o reconhecimento da existência de grupos informais atuando paralelamente aos grupos formais. Bernardes \& Marcondes (2000, p. 87) apresentam algumas diferenças entre esses dois grupos em relação a quatro variáveis: funções, estrutura, fronteira e coesão - Quadro 4.

Quadro 4- Diferenças entre as variáveis do grupo formal e as do grupo informal

\begin{tabular}{|l|l|l|}
\hline Variáveis & \multicolumn{1}{|c|}{ Grupo Formal } & \multicolumn{1}{c|}{ Grupo Informal } \\
\hline Funções & Atender necessidades da organização & Atender necessidades dos membros \\
\hline Estrutura & $\begin{array}{l}\text { Imposta em decorrência dos processos de produção } \\
\text { de bens e serviços }\end{array}$ & $\begin{array}{l}\text { Autônoma em decorrência das simpatias e } \\
\text { antipatias pessoais }\end{array}$ \\
\hline Fronteira & Aberta para a troca de participantes & Fechada para pessoas de fora \\
\hline Coesão & Baixa pela predominância de metas co-orientadas & Alta pela predominância de metas cooperativas \\
\hline
\end{tabular}

Fonte: Bernardes \& Marcondes (2000, p. 87). 
Tanto as teorias que compõem a Abordagem Clássica como a Abordagem das Relações Humanas têm seu campo de atuação basicamente restrito ao ambiente interno da entidade. Bateman \& Snell (1998, p. 57-58) enumeram duas críticas direcionadas às abordagens clássicas que, na concepção dos autores, incluem a Abordagem das Relações Humanas: 1) ignoravam o relacionamento entre organização e ambiente externo e 2) normalmente destacavam um aspecto da organização ou seus empregados em detrimento de outras considerações. Uma terceira abordagem organizacional vem justamente se contrapor a essa visão ao considerar que a organização é um sistema aberto. Esses autores afirmam que:

Em resposta a essas críticas, os estudiosos da administração, durante os anos 50, voltaram-se para os detalhes da organização para tentar entendê-la como um sistema total. Esses esforços eram baseados numa abordagem científica geral chamada teoria dos sistemas. [...] a teoria dos sistemas fornece um meio para interpretar as organizações. A teoria dos sistemas traz uma visão holística de todo o sistema organizacional e enfatiza os processos. Conceitos importantes da teoria dos sistemas incluem sistemas abertos e fechados, eficiência e eficácia, subsistemas, equifinalidade e sinergia.

Morgan (1996) considera que a principal inspiração dessa abordagem vem de Ludwig van Bertallanffy. O enfoque sistêmico, na concepção dessa autora, parte do reconhecimento de que "[...] indivíduos, grupos e organizações têm necessidades que devem ser satisfeitas [...]". Diante desse reconhecimento, a ênfase naturalmente recai no ambiente. Portanto, um ponto fundamental dentro da Abordagem Sistêmica está no princípio de que organizações estão 'abertas' ao ambiente no qual atuam como forma de garantir a sobrevivência. Sinteticamente, Morgan enumera os assuntos-chave relacionados a essa abordagem:

- ênfase sobre o ambiente dentro do qual a organização existe;

- definição de uma organização em termos de subsistemas inter-relacionados;

- tentativa de estabelecer congruências entre diferentes sistemas para identificar e eliminar disfunções potenciais.

É dentro desse contexto da Abordagem Sistêmica que emerge uma quarta abordagem organizacional: a Abordagem Contingencial. Segundo Bateman \& Snell (1998, p. 59) essa abordagem foi construída a partir das idéias da teoria dos sistemas. Como afirmam os autores, “[...] a perspectiva contingencial refuta os princípios universais da administração pela afirmação de que uma variedade de fatores, tanto internos quanto externos à empresa, pode afetar o desempenho da organização". Como conseqüência, não existiria uma melhor forma de administrar e organizar uma organização, pois as circunstâncias mudam.

Como destaca Morgan (1996), um dos estudos de maior influência na Abordagem Contingencial foi realizado por Burns \& Stalker nos anos 50 do qual duas conclusões importantes são apresentadas pela autora: 1) é possível formar um contínuo de formas 
organizacionais que se classificam de mecanicista até orgânica e 2) formas mais flexíveis são necessárias para lidar com ambientes em mudança. Vasconcellos \& Hemsley (1989, p. 21) apresentam as características principias desses dois extremos de formas organizacionais identificados por Burns \& Stalker.

Características de organizações mecanicistas:

- alto nível de especialização;

- preocupação em aperfeiçoar os meios é maior do que em atingir os fins;

- definição de direitos e obrigações traduzidas em funções bem delineadas;

- estrutura hierárquica de controle, autoridade e comunicação;

- interação mais freqüente é a vertical;

- insistência quanto à lealdade e obediência;

- prestígio maior associado com conhecimento interno da empresa em relação a conhecimentos gerais.

Características de organizações orgânicas:

- a tarefa individual muda constantemente como resultado da interação com os demais membros da organização;

- o sistema de controle é menos baseado no contrato de trabalho feito entre o indivíduo e a organização representada pelo seu chefe e mais baseado no consenso do que é bom para o grupo;

- a autoridade pode mudar dependendo de quem é mais capaz para realizar a tarefa;

- comunicação lateral além de vertical;

- o conteúdo da comunicação na organização tende a ter mais informação e conselho ao invés de instruções e decisões.

Ao comparar organizações colocadas nos dois extremos identificados, Burns \& Stalker, conforme Vasconcellos \& Hemsley (1989, p. 21), concluíram que:

O grau de inovação, crescimento e satisfação das pessoas foi muito maior nas organizações do tipo orgânico quando elas estavam envolvidas com inovação. Por outro lado, as organizações voltadas para produção em massa e com ambientes estáveis eram mais bem sucedidas quando apresentavam características do tipo mecanicista.

Outro importante estudo - relacionado à Abordagem Contingencial - foi realizado por Joan Woodward envolvendo a análise de estruturas organizacionais de 100 empresas industriais da Inglaterra das quais foram coletadas informações relativas a: 1) história, background e objetivos; 2) descrição dos processos e métodos de produção; 3) formas e rotinas segundo as quais a empresa se organizava e operava; 4) fatos e números que poderiam 
ser usados para se prever o sucesso comercial das empresas. Esses dados foram utilizados para identificar as diferenças interfirmas na estrutura organizacional, nos processos operacionais e na lucratividade relativa (GIBSON et al, 1988 , p. 296).

Os estudos de Woodward, como menciona Morgan (1996), estabeleceram relação entre tecnologias e estruturas das organizações bem-sucedidas, ou seja, a tecnologia impõe solicitações específicas sobre os indivíduos e a organização, de forma que deve se buscar uma estrutura que seja apropriada a tais solicitações. Assim, organizações burocrático-mecanicistas são apropriadas para empresas que utilizam tecnologia de produção em massa, enquanto que para empresas de produção unitária (pequenos lotes) ou que utilizam tecnologia por processo uma outra abordagem é necessária. Enfim, dada qualquer tecnologia, existe uma ampla possibilidade de formas organizacionais que pode ser adotada.

As pesquisas de Burns \& Stalker e Woodward “[...] demonstraram que, no processo de organizar, várias escolhas podem ser utilizadas". Esses pesquisadores foram, ademais, os primeiros a sugerir que uma organização eficaz depende da consistência entre estratégia, estrutura, ambiente externo e envolvimento e necessidade das pessoas, aspectos que representam a essência da moderna teoria contingencial (MORGAN, 1996).

No entanto, Gibson et al (1988, pg. 300) destacam que a variável ambiente sempre se apresentava durante as interpretações das relações entre tecnologia e design da organização, portanto, um outro estudo merece destaque dentro da Abordagem Contingencial. Trata-se do trabalho realizado por vários pesquisadores tendo à frente Paul Lawrence \& Jay Lorsch cuja principal hipótese foi desmembrada por Gibson et al (1988, p. 302-303) em três outras: 1) quanto maior a taxa de manutenção de mudança, tanto menor a informação certa; 2) quanto mais longo o tempo de feedback dentro do sub-ambiente em questão, tanto maior a diferenciação entre os sub-ambientes; e 3) quanto maior a diferenciação entre subsistemas, tanto maior a necessidade de integração e a dificuldade de consegui-la.

Morgan (1996) refere estas como sendo as idéias principias desse estudo:

1. diferentes tipos de organizações são necessários para lidar com diferentes condições de mercado e tecnologia; e

2. organizações que operam em ambientes incertos e turbulentos precisam atingir um grau mais alto de diferenciação interna do que aquelas que estão em ambientes menos complexos e mais estáveis.

Vasconcellos \& Hemsley (1989, p. 20) afirmam que Lawrence \& Lorsch:

[...] realizaram pesquisa mostrando que organizações em ambientes sujeitos a diferentes níveis de turbulência tinham estruturas diferentes. Essas diferenças aconteceram dentro de uma mesma 
organização, desde que os ambientes das suas várias unidades assim como a natureza da atividade fossem diferentes.

Assim, fatores ambientais são variáveis independentes que determinam a estrutura organizacional da entidade. Dentro dessa abordagem, Morgan (1996, p. 75) dispõe que a ênfase é colocada na compreensão das relações entre organizações e seus ambientes, sendo aquelas consideradas sistemas abertos que são mais bem compreendidas como processos contínuos em lugar de coleções de partes.

\subsection{Abordagem da Configuração Organizacional}

Uma quinta abordagem busca unir as conclusões das concepções anteriores e pode ser considerada como evolução da contingencial. É conhecida como Abordagem da Configuração de Estruturas Organizacionais e tem como um de seus principais teóricos Henry Mintzberg. Estas são algumas premissas dessa abordagem:

1. Na maior parte das vezes, uma organização pode ser descrita em termos de algum tipo de configuração estável de suas características: para um período distinguível de tempo, ela adota uma determinada forma de estrutura adequada a um determinado tipo de contexto, o que faz com que ela se engaje em determinados comportamentos que dão origem a um determinado conjunto de estratégias.

2. Esses períodos de estabilidade são ocasionalmente interrompidos por algum processo de transformação - um salto quântico para outra configuração.

3. Esses estados sucessivos de configuração e períodos de transformação podem se ordenar ao longo do tempo em seqüências padronizadas, por exemplo descrevendo ciclos de vida de organizações (MINTZBERG et al, 2000, p. 224).

Segundo Morgan (1996) essa abordagem tem como ponto inicial “[...] mostrar que a organização eficaz depende do desenvolvimento de um conjunto coeso de relações entre planejamento da estrutura, a idade, o tamanho, a tecnologia da empresa e as condições existentes no ramo industrial no qual se acha operando". Para Hall (1984, p. 31) "Essa é uma abordagem multifacetada, predominantemente baseada nos modos como as organizações se estruturam para fazer face às várias contingências que enfrentam”.

Mintzberg (2003, p. 139) destaca que os estudos sobre a relação entre estrutura e desempenho - especialmente quanto à estrutura de empresas de alto e de baixo desempenho mostram a tendência de atribuir a eficácia ao ajustamento entre alguns parâmetros de design e um determinado fator situacional. No entanto, o estudo de Khandwalla (1974), um dos precursores da Abordagem da Configuração, tendo em foco firmas norte-americanas de manufatura, constatou que existe uma correlação entre tecnologia, integração vertical, descentralização e controle, de tal forma que, para que uma entidade tivesse performance 
superior seria necessário que essas quatro dimensões organizacionais estivessem propriamente alinhadas, ou seja, constatou que a eficácia dependia dos inter-relacionamentos entre parâmetros de design, ou ainda, como afirma Mintzberg (2003, p. 140), “[...] a eficácia era dependente [...] da utilização de diferentes parâmetros de forma consistente e integrada".

Com base nessas direções de estudos, duas conclusões sobre a eficácia estrutural emergem: de um lado, tem-se a hipótese da congruência - a estruturação eficaz requer um ajuste rigoroso entre fatores situacionais e parâmetros de design; de outro, tem-se a hipótese de configuração - a estrutura eficaz requer consistência interna entre parâmetros de design, ou seja, a organização eficaz desenha uma configuração lógica dos parâmetros de design (MINTZBERG, 2003, p. 140). Essas duas hipóteses podem ser complementares quando se considera que uma organização pode escolher tanto os seus parâmetros de design quanto determinados aspectos de sua situação. Conseqüentemente, uma terceira hipótese, preferida por Mintzberg (2003, p. 140), pode ser elaborada, a saber: a estruturação eficaz requer consistência entre parâmetros de design e fatores contingenciais.

Um aspecto importante dentro dessa abordagem é que não existe mais variável dependente ou independente, mas uma interdependência entre parâmetros de design e fatores situacionais. Em outras palavras, enquanto nas demais abordagens analisadas havia sempre uma ou mais variáveis que determinava(m) outra(s), na abordagem da configuração ampliada, quando se considera que as configurações são sistemas, não se pode afirmar que alguma parte seja dependente de uma outra, mas, ao contrário, todas estão integradas.

A Abordagem da Configuração, portanto, considera que qualquer organização tende a ser eficaz quando sua estrutura organizacional é determinada pela consistência entre parâmetros de design e fatores situacionais. Por outro lado, Mintzberg (1981) afirma que quando não existe consistência entre as referidas características, a entidade não funciona efetivamente, não obtém uma harmonia natural.

Parâmetros de design são, nas palavras de Mintzberg (2003, p. 33), “[...] as alavancas que podem ser acionadas e os botões que podem ser girados para afetar a divisão do trabalho e a coordenação das tarefas na organização" que, conforme visto, representam os elementos principais para a definição da estrutura de uma organização, dentro da concepção desse autor. Os parâmetros de design incluem basicamente aspectos internos da entidade e estão divididos em quatro grandes grupos: 1) design das posições, 2) design da superestrutura, 3) design dos vínculos laterais e 4) design do sistema de tomada de decisão. O Quadro 5 apresenta esses grupos com os seus respectivos parâmetros de design. 
Quadro 5 - Parâmetros de design - abordagem da configuração de Mintzberg

\begin{tabular}{|l|l|}
\hline \multicolumn{1}{|c|}{ Grupo } & \multicolumn{1}{c|}{ Parâmetro de design } \\
\hline Design das posições & $\begin{array}{l}\text { Especialização da tarefa } \\
\text { Formalização do comportamento } \\
\text { Treinamento e doutrinação }\end{array}$ \\
\hline Design da superestrutura & $\begin{array}{l}\text { Agrupamento em unidades } \\
\text { Tamanho da unidade }\end{array}$ \\
\hline Design dos vínculos laterais & $\begin{array}{l}\text { Sistemas de planejamento e controle } \\
\text { Instrumentos de vínculo }\end{array}$ \\
\hline Design do sistema de tomada de decisões & $\begin{array}{l}\text { Descentralização vertical } \\
\text { Descentralização horizontal }\end{array}$ \\
\hline
\end{tabular}

Fonte: Adaptado de Mintzberg (2003, p. 37).

Para Mintzberg (2003, p. 112-113) os relacionamentos entre os parâmetros de design são recíprocos, ao invés de seqüenciais: "Os parâmetros do design formam um sistema integrado em que cada um deles está vinculado a todos os outros: qualquer mudança em um parâmetro provoca mudança em todos". Os fatores situacionais, por sua vez, incluem quatro aspectos: idade e tamanho; sistema técnico; ambiente; e poder (MINTZBERG, 2003).

Os parâmetros de design e os fatores situacionais adotados por uma organização favorecem um mecanismo de coordenação utilizado, assim como, uma parte da entidade que terá maior poder de tomada de decisão. Em outras palavras, a consistência entre os aspectos básicos determina o mecanismo de coordenação favorecido e a parte-chave da organização. Mintzberg (2001) identifica seis mecanismos de coordenação e seis partes existentes em uma organização. Tanto os mecanismos de coordenação como as partes-chave de uma organização serão objeto dos tópicos seguintes, em que também serão descritos os parâmetros de design e os fatores situacionais.

\subsubsection{Mecanismos de Coordenação}

Os mecanismos de coordenação são os meios mais básicos de uma estrutura organizacional se manter unida. Mintzberg (2003, p. 14) afirma que esses mecanismos “[...] parecem explicar as maneiras fundamentais pelas quais as organizações coordenam seu trabalho". São seis os mecanismos de coordenação identificados por esse autor: ajuste mútuo, supervisão direta, padronização dos processos de trabalho, padronização dos outputs, padronização de habilidades e padronização de normas. As condições específicas de cada entidade irão favorecer um desses mecanismos de coordenação.

O ajustamento mútuo é obtido através de comunicação informal. Assim, existe uma

forte interação entre as pessoas para que ocorra a coordenação. É um mecanismo de coordenação que pode ser utilizado tanto por organizações mais simples quanto por 
organizações mais complexas. Assim, pode ocorrer entre dois remadores em uma canoa ou em uma organização cujo objetivo é levar o homem à lua pela primeira vez. O controle sobre o trabalho permanece com os operadores (MINTZBERG, 2003, p. 14-15; 2001, p. 142).

Na coordenação por supervisão direta existe uma pessoa responsável pelo trabalho de outras, controlando-lhes e orientando-lhes em suas atividades. Assim, torna-se necessário um cérebro que coordene o trabalho de várias pessoas. Emerge quando as organizações passam a envolver mais pessoas realizando uma atividade, como, por exemplo, quinze pessoas em uma canoa necessitando de um líder que coordene o trabalho de todos. Pode-se afirmar que a supervisão direta surge como mecanismo de coordenação quando um certo número de pessoas precisa trabalhar juntas (MINTZBERG, 2003, p. 15-16; 2001, p. 142).

A coordenação por padronização dos processos de trabalho é favorecida quando o conteúdo do trabalho for especificado ou programado. Como conseqüência, há uma limitação na liberdade de ação das pessoas. O controle sobre o trabalho é transferido para analistas que programam ou especificam os procedimentos a serem seguidos pelos demais membros da organização. Têm-se, como exemplo, instruções de montagem de um brinquedo em que cada passo para a montagem é especificado. (MINTZBERG, 2003, p. 16; 2001, p. 142).

O quarto mecanismo de coordenação é a padronização dos outputs na qual se especificam os resultados esperados do trabalho ou as dimensões do produto, o que faz com que a interface entre tarefas seja predeterminada. $\mathrm{O}$ controle sobre as atividades pertence a um analista e pode-se exemplificar o caso de um gerente divisional que recebe ordens para aumentar as vendas em 10\% (MINTZBERG, 2003, p. 16-17; 2001, p. 142).

Com a coordenação por padronização das habilidades (conhecimento) especifica-se o treinamento exigido para o desempenho do trabalho. Em geral, a padronização ocorre fora da organização - universidades, escolas profissionais etc. O controle sobre o trabalho passa dos analistas para os operadores depois de treinados, assim, atinge indiretamente o controle e a coordenação do trabalho, ao invés de diretamente, como as duas outras formas de padronização. Um exemplo é o caso de um anestesista e um cirurgião que não precisam de muita comunicação para a realização de uma operação, pois em virtude de seus treinamentos, sabem exatamente o que um espera do outro (MINTZBERG, 2003, p. 17; 2001, p. 142-143).

O último mecanismo de coordenação é a padronização das normas em que está especificado um conjunto de crenças comuns a todos os trabalhadores as quais servem de base para a obtenção da coordenação. O exemplo apresentado por Mintzberg (2001, p.142) é o de uma ordem religiosa onde a crença comum existente é a de atrair convertidos, de forma que todos trabalhem juntos para atingir esse objetivo. 
Para Mintzberg (2003, p. 17; 2001, 143) os mecanismos de coordenação parecem seguir certa ordem: "[...] à medida que o trabalho organizacional torna-se mais complicado, o meio favorecido de coordenação parece passar do ajustamento mútuo para a supervisão direta e, depois, para a padronização [...]”. Chegando à padronização, o meio preferível é a padronização dos processos de trabalho ou de normas, que não sendo possível, levará à de outputs ou de habilidades as quais podem iniciar um novo ciclo. Assim, em determinado momento, um mecanismo de coordenação será privilegiado em detrimento dos demais, podendo ser substituído ao longo do tempo. Na prática, a organização não pode confiar em apenas um mecanismo de coordenação, ou seja, todos os mecanismos serão encontrados em organizações razoavelmente bem-desenvolvidas (MINTZBERG, 2003, p. 18; 2001, p. 143).

\subsubsection{Partes-Chave da Organização}

Considerados os seis mecanismos de coordenação do trabalho, segue-se a descrição das seis partes básicas de uma organização, tal como identificadas por Mintzberg (2001, 2003), que são: núcleo operacional, linha intermediária, tecnoestrutura, assessoria de apoio, cúpula estratégica e ideologia. Essas partes encontram-se divididas na organização como apresentado na Figura 3.

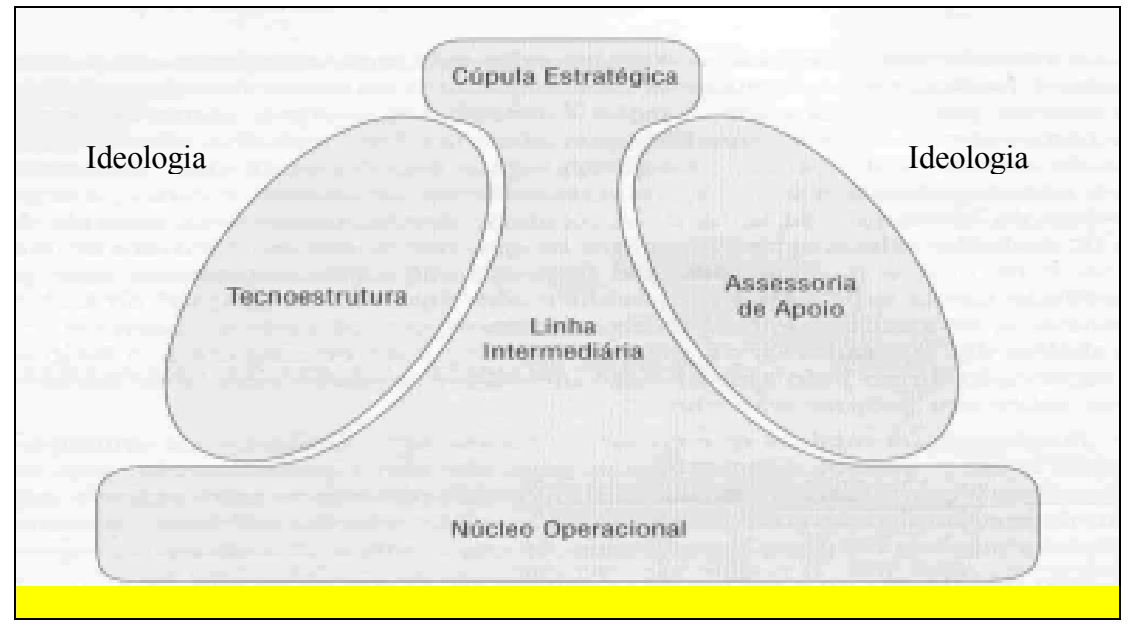

Figura 3 - Seis partes básicas da organização Fonte: Adaptado de Mintzberg (2003, p. 22).

No núcleo operacional (base da organização) estão concentrados os operadores que executam o trabalho básico diretamente relacionado à fabricação dos produtos e prestação dos serviços. Desempenham quatro funções básicas: 1) assegurar inputs para a produção, 2) transformar inputs em outputs, 3) distribuir outputs e 4) fornecer apoio direto às funções de input, de transformação e de output. É nessa parte da organização em que a padronização 
ocorre com maior intensidade para reduzir distúrbios externos. No entanto, o nível de padronização dependerá da natureza do trabalho executado pelos operadores, de forma que a padronização dos operários das linhas de montagem de automóveis tende a ser maior do que aquela realizada sobre professores universitários (MINTZBERG, 2003, p. 23).

A cúpula estratégica (topo da organização) concentra pessoas cuja responsabilidade sobre a entidade é global: o presidente ou outra denominação sinônima; os dirigentes de alto nível com preocupações globais; e as pessoas que fornecem apoio direto à alta administração, tais como, secretárias, assistentes etc. Possui três conjuntos de obrigações: 1) supervisão direta, 2) administração das condições fronteiriças da organização - relações com o ambiente e 3) desenvolvimento da estratégia da organização. O trabalho realizado na cúpula pode ser caracterizado como pouco repetitivo e pouco padronizado (MINTZBERG, 2003, p. 24-25).

A linha intermediária é o elo de ligação entre cúpula estratégica e núcleo operacional. Gerentes intermediários possuem autoridade formal sobre o núcleo operacional e exercem a coordenação dos operadores por meio de supervisão direta. Essa linha pode ser tanto escalar, ou seja, uma linha única ligando o topo à base, como pode ser dividida, de tal forma que um subordinado possua mais de um superior. A necessidade desse grupo de gerentes depende do porte da entidade e da necessidade de coordenação por meio de supervisão direta. Como tarefas básicas dos gerentes intermediários destacam-se: 1) coletar informações de feedback sobre desempenho de sua unidade e transferi-las aos gerentes acima; 2) intervir no fluxo de decisões; 3) gerenciar situações fronteiriças, manter contatos com outros gerentes, analistas, assessores de apoio e outras pessoas cujo trabalho é interdependente com o de sua unidade; e 4) formular a estratégia para sua unidade (MINTZBERG, 2003, p. 25-26).

$\mathrm{Na}$ tecnoestrutura estão concentrados os analistas que, a serviço da organização, interferem no trabalho de outras pessoas. Conseqüentemente, quanto maior o nível de padronização, maior a confiança na tecnoestrutura. Três tipos de analistas podem ser destacados: 1) de sistemas e métodos - padronizam processos de trabalho (engenheiros industriais), 2) de planejamento e controle - padronizam outputs (contadores, planejadores de longo prazo) e 3) de pessoal - padronizam as habilidades (treinadores e recrutadores). Os analistas da tecnoestrutura podem atuar em qualquer nível da organização quando essa é caracterizada como bem desenvolvida (MINTZBERG, 2003, p. 26-27).

A assessoria de apoio é formada por unidades especializadas que apóiam a organização fora de seu fluxo de trabalho operacional. Esses assessores diferenciam-se daqueles da tecnoestrutura por não estarem preocupados com padronização, além do que, não podem ser vistos como unidades de aconselhamento. A justificativa para a existência dos 
assessores é o controle que a organização pode exercer sobre os serviços que prestam, o que não seria possível caso tivesse que obtê-los no mercado. Tais assessores podem ser encontrados em qualquer parte da organização: no topo - departamentos de relações públicas e consultoria jurídica; na linha intermediária - departamentos de relações industriais e de preços; na base - restaurantes e folhas de pagamento (MINTZBERG, 2003, p.27-28).

Como última parte da organização, tem-se a ideologia, que representa uma forte cultura presente na entidade. Abrange não apenas as tradições como também as crenças de uma organização, sendo exatamente esses os elementos que distinguem uma entidade de outras e que infundem vida no esqueleto da estrutura. Distinção importante precisa ser feita entre as crenças da organização que representam sua ideologia e as crenças da sociedade que a envolvem. O impulso da ideologia pode ficar perdido diante dos demais. No entanto, quando esse impulso domina a entidade, o mecanismo de coordenação privilegiado é a padronização das normas (MINTZBERG, 2003, p. 325; 2001, p. 141).

O Quadro 6 apresenta o relacionamento entre mecanismos de coordenação e parteschave da organização, indicando qual mecanismo de coordenação é privilegiado quando determinada parte da organização tem o poder de tomada de decisão.

\section{Quadro 6 - Relacionamento entre as partes-chave da organização e os mecanismos de coordenação}

\begin{tabular}{|l|l|}
\hline Parte-chave da organização & Principal mecanismo de coordenação \\
\hline Núcleo operacional & Padronização das habilidades \\
\hline Ápice estratégico & Supervisão direta \\
\hline Linha intermediária & Padronização dos outputs \\
\hline Tecnoestrutura & Padronização dos processos de trabalho \\
\hline Assessorias de apoio & Ajustamento mútuo \\
\hline Ideologia & Padronização das normas \\
\hline
\end{tabular}

Fonte: Adaptado de Mintzberg (2001, p. 151).

\subsubsection{Descrição dos Parâmetros de Design}

\subsubsection{Design das Posições Individuais}

O grupo design das posições inclui os seguintes parâmetros: especialização da tarefa (trabalho), formalização do comportamento e treinamento e doutrinação. O primeiro surge com a divisão do trabalho. Chiavenato (1986, p. 112) considera que "[...] a divisão do trabalho conduz à especialização e à diferenciação das tarefas, ou seja, à heterogeneidade". Maximiano (1989, p. 153) afirma que a especialização é uma conseqüência da divisão do trabalho. Gibson et al $(1988$, p. 239) destacam dois problemas ligados à definição de tarefas: 
1) extensão em que as tarefas são especializadas e 2) possibilidade de dividir o trabalho em várias subunidades.

Dessa forma, a especialização de tarefas possui duas dimensões. A primeira está relacionada à extensão ou escopo, ou seja, “[...] quantas diferentes tarefas estão contidas em cada trabalho e quão ampla ou estreita é cada uma dessas tarefas". Assim, tem-se em um extremo aquele trabalhador que pode realizar qualquer tarefa, o chamado 'pau para toda obra'. De outro lado, tem-se aquele que realiza tarefas altamente especializadas, repetindo-as em seu dia-a-dia. A segunda dimensão está relacionada à 'profundidade' ou ao controle que se tem sobre o trabalho. Nesse ponto, tem-se em um extremo o trabalhador que realiza tarefas sem ter noção de como ou por que a realiza; na outra ponta, tem-se o que possui total controle sobre as tarefas, não apenas executando-as. Essas duas dimensões de especialização de tarefas são designadas de: 1) especialização horizontal do trabalho e seu oposto enriquecimento horizontal do trabalho, e 2) especialização vertical do trabalho e seu oposto enriquecimento vertical do trabalho (MINTZBERG, 2003, p. 38).

Gibson et al (1988, p. 239) apresentam duas vantagens da divisão do trabalho:

1. Se a tarefa contém poucas atividades, é possível treinar os substitutos para o pessoal que saiu, foi transferido ou se ausentou. O esforço mínimo de treinamento gera custos de treinamento mais baixos.

2. Quando a tarefa envolve apenas um número limitado de atividades, o empregado pode tornarse excelente nessa tarefa. Esse alto nível de eficiência reflete-se na melhor qualidade do produto.

Mintzberg (2003, p. 38-39) menciona que a especialização horizontal de tarefas pode aumentar a produtividade. Para justificar sua afirmação, o autor expõe as razões encontradas por Adam Smith em suas experiências: 1) a maior destreza do trabalhador pela especialização em uma só tarefa, 2) a economia do tempo gasto na troca de tarefas, e 3 ) o desenvolvimento de novos métodos e máquinas em decorrência da especialização. Em suma, o principal fator que conduz à produtividade é a repetição:

A especialização horizontal aumenta a repetição do trabalho, facilitando, assim, sua padronização. Os outputs podem ser produzidos mais uniforme e eficientemente. A especialização horizontal focaliza a atenção do trabalhador, facilitando a aprendizagem. Uma razão final para a especialização é que ela permite que o indivíduo se adapte à tarefa.

Mintzberg (2003, p. 39) afirma que a especialização horizontal, por limitar a perspectiva do trabalhador, dificulta o relacionamento de seu trabalho com os demais, provocando especialização vertical. Conseqüentemente, “[...] o controle do trabalho é, freqüentemente, transferido a um gerente com a visão abrangente necessária para coordenar o 
trabalho por supervisão direta ou a um analista que possa fazê-lo por padronização", mas o autor lembra que tal fato nem sempre ocorre. Sintetizando, cargos não especializados têm alta especialização em ambas direções, enquanto que, cargos especializados (profissionais) possuem especialização apenas horizontal (MINTZBERG, 2001, p.144).

Por outro lado, a especialização do trabalho também traz problemas, quais sejam: 1) de balanceamento - determinados trabalhadores ficariam ociosos enquanto outros estariam sobrecarregados; 2) de sentimento negativo em relação ao trabalho - pode afetar a motivação para bem executá-lo; 3) de comunicação e coordenação (MINTZBERG, 2003, p. 40).

Dessa forma, os conceitos de ampliação vertical e horizontal surgem para superar tais transtornos, provocando o enriquecimento da tarefa. Gibson et al $(1988,148)$ afirmam que esse enriquecimento pode aumentar o desempenho e a satisfação no trabalho. Em suma, destacam que "A base desta idéia é a de que os fatores que respondem às necessidades humanas de crescimento psicológico, como responsabilidade, desafio no trabalho e realização, devem-se combinar com os chamados fatores higiênicos para levar ao desempenho eficaz".

Mintzberg (2003, p. 41-42) menciona que "Quando um trabalho é verticalmente ampliado ou 'enriquecido', não apenas o trabalhador executa maior número de tarefas, mas também obtém maior controle sobre elas". Para o autor, existem fracassos e sucessos na ampliação das tarefas, sendo que os resultados dependem do trabalho executado. Ademais, menciona a questão dos tradeoffs, ou seja, "a ampliação do trabalho compensa na extensão em que os ganhos decorrentes de trabalhadores mais motivados em determinada tarefa compensam as perdas da especialização técnica menos otimizada". Outro aspecto destacado por Mintzberg (2003, p. 43-45) referente à especialização do trabalho diz respeito à relação que possui com sua localização na organização. De forma resumida, a relação entre especialização do trabalho e a posição na organização é apresentada no Quadro 7.

Quadro 7 - Especialização do trabalho por parte da organização

\begin{tabular}{l|c|l|l}
\hline & & \multicolumn{3}{|c}{ Especialização horizontal } \\
\hline \multirow{2}{*}{$\begin{array}{l}\text { Especialização } \\
\text { Vertical }\end{array}$} & Alta & $\begin{array}{l}\text { Trabalhos não especializados (núcleo } \\
\text { operacional e unidades de apoio) }\end{array}$ & $\begin{array}{l}\text { Certos trabalhos gerenciais de nível } \\
\text { mais baixo }\end{array}$ \\
\cline { 2 - 4 } & Baixa & $\begin{array}{l}\text { Trabalhos profissionais (núcleo } \\
\text { operacional e unidades de apoio) }\end{array}$ & Todos os outros trabalhos gerenciais \\
\hline
\end{tabular}

O segundo parâmetro que pertence ao grupo do design das posições é a formalização do comportamento. Chiavenato (1986, p. 301) afirma que, de acordo com o princípio da definição funcional, "O conteúdo de cada posição e as relações formais entre os ocupantes 
devem ser claramente definidos por escrito". O autor destaca ainda que os deveres, as atribuições ou as relações de cada participante da empresa devem, não somente constar no organograma, mas também ser claro e completamente definidos por escrito, “[...] através daquilo que chamamos Descrição de Cargos". Definindo 'descrição de cargos', Chiavenato refere:

Descrição de Cargos é o relacionamento das tarefas de um ou mais (se idênticos) postos de trabalho, definindo a subordinação do mesmo, a qualidade e a quantidade de autoridade atribuída ao seu ocupante para responder às responsabilidades que lhe foram delegadas.

Mintzberg (2003, p. 45) menciona que padronização do comportamento “[...] representa o modo pelo qual a organização prescreve a separação de seus membros, essencialmente a padronização de seus processos de trabalho”. O autor enumera três tipos de formalização do comportamento, a saber:

- Pela posição, em que as especificações estão associadas à própria atividade, como em uma descrição de tarefas;

- Pelo fluxo de trabalho, em que as especificações estão associadas ao trabalho, como no caso de uma listagem de ordens de impressão;

- Por regras, em que as especificações são emitidas para o geral, como os regulamentos - do uso de uniformes a formulários - presentes nos denominados manuais de políticas.

Independente do tipo de formalização, o efeito sobre quem executa o trabalho é ter o seu comportamento padronizado, assim, em geral, um analista da tecnoestrutura é quem tem o 'poder' sobre a forma como esse trabalho deve ser executado. Conseqüência direta é que a formalização do comportamento conduz à especialização vertical do trabalho, ademais, “[...] reforça a razão por que a formalização está relacionada à especialização horizontal: os trabalhos mais limitados e menos especializados são os mais simples, mais repetitivos e mais suscetíveis a alto grau de formalização" (MINTZBERG, 2003, p. 45).

As justificativas enumeradas por Mintzberg (2003, p. 46) para a padronização são:

- reduz a variabilidade do comportamento, tornando-o previsível e controlável;

- assegura a consistência da mecanização que leva a uma produção eficiente;

- garante que seja dado tratamento igual aos clientes;

- reflete um desejo arbitrário por ordem - exigência de que todos os jogadores de tênis usem roupas brancas.

Organizações que se apóiam na formalização do comportamento são identificadas como burocracias. Assim, Mintzberg (2003, p. 48) define uma estrutura como sendo burocrática "[...] na extensão em que seu comportamento seja predeterminado ou previsível, na realidade, padronizado". Por outro lado, uma organização quando não tem seu 
comportamento formalizado é qualificada como orgânica. Assim, têm-se os dois extremos do continuиm identificados por Burns \& Stalker.

No entanto, a formalização do comportamento pode produzir efeitos negativos, quais sejam: cristalização do comportamento, clientes maltratados, aumentos do absenteísmo, turnover elevado, greves e, às vezes, subversão das operações da organização (MINTZBERG, 2003, p. 48-49). Pode também apresentar relação com a localização na organização: para quem se encontra na cúpula, a tendência é que a formalização seja reduzida, ou seja, apresenta característica orgânica; para quem se encontra na base da entidade, existe maior tendência de formalização do comportamento (MINTZBERG, 2003, p. 50).

Por fim, o último parâmetro do grupo design das posições é treinamento e doutrinação. Segundo Mintzberg (2003, p. 51) treinamento “[...] refere-se ao processo pelo qual são ensinados habilidades e conhecimentos relacionados ao trabalho [...]”, enquanto que, doutrinação "[...] é o processo pelo qual as normas organizacionais são adquiridas". O treinamento é um importante parâmetro de design quando o trabalho é considerado profissional que, segundo Mintzberg (2003, p. 52), é aquele trabalho complexo e não racionalizado, ainda que parcialmente registrado e especificado. Ainda de acordo com esse autor, ao se especificar o conhecimento e as habilidades por meio do treinamento o que acontece é a padronização das habilidades.

O treinamento, em geral, ocorre fora da entidade de trabalho como, por exemplo, em uma universidade. Assim, os treinandos somente poderão desenvolver seus trabalhos quando "[...] tenham internalizado as habilidades padronizadas e o corpo associado de conhecimento [...]". No entanto, o programa de treinamento não é suficiente para fornecer todas as habilidades e conhecimentos necessários, sendo, por esse motivo, indispensável um processo de aprendizagem no trabalho, como um estágio, para que a pessoa possa ser considerada completamente apta para a realização do trabalho (MINTZBERG, 2003, p. 53). O treinamento está presente em trabalhos profissionais, sendo substituto da formalização do comportamento como meio para se atingir a padronização (burocratização) do comportamento.

Doutrinação, segundo Mintzberg (2003, p. 53), “[...] é o rótulo utilizado para o parâmetro de design pelo qual a organização, formalmente, socializa seus membros em seu próprio benefício". Socialização, para esse autor, está relacionada ao processo de transmissão do sistema de valores, normas e padrões de comportamento de uma organização ao membro que está sendo admitido. Motta (1985, p. 82) compreende socialização como “[...] o processo global pelo qual um indivíduo, nascido com uma gama de potencialidades comportamentais 
muito ampla, é levado a desenvolver um comportamento muito mais restrito, de acordo com os padrões de seu grupo".

Ainda que parte do processo de doutrinação aconteça fora da organização durante o treinamento, é, em seu interior, que ocorre com maior intensidade, sendo que, porção significativa desse processo realiza-se antes que a pessoa inicie o trabalho, forma de assegurar a socialização necessária para que o comportamento seja tal como desejado (MINTZBERG, 2003, p. 53-54). Motta (1985, p. 85-87) identifica algumas formas determinantes para que a socialização possa ser promovida dentro da organização, a saber:

- seleção de candidatos - somente aqueles que apresentam as características 'aceitáveis'pela organização são admitidos;

- treinamento - na medida em que esse, pelo menos em princípio, desenvolve habilidades técnicas diretamente ligadas às tarefas para desempenho das funções, facilita a mudança de comportamento em termos de atividades funcionais;

- aprendizado - é o modo de socialização preferido nas organizações nas quais os valores a serem transmitidos são tão importantes quanto as realizações. O método implica na delegação da organização a um de seus membros da responsabilidade pela socialização de determinados recém-chegados;

- mortificação - experiências dramáticas que têm por objetivo separar o indivíduo de suas atitudes e formas de pensar anteriores no que tange à auto-imagem;

- $\quad$ antecipação - desenvolvimento de forte identificação do indivíduo com um grupo ao qual ainda não pertencia.

Em suma, doutrinação está relacionada a programas e técnicas por meio dos quais são padronizados normas e valores com que os membros da organização devem estar de acordo. Também representa um substituto da formalização, assim como, do próprio treinamento (MINTZBERG, 2001, p.144). Mintzberg (2003, p. 54) afirma que treinamento, independente de sua localização na organização, "[....] é mais importante quando os trabalhos são complexos, envolvem dificuldade, habilidades específicas e corpos de conhecimentos sofisticados - trabalhos de natureza essencialmente profissional". Por outro lado, a doutrinação “[...] é mais importante quando os trabalhos são sensíveis ou remotos e quando a cultura e a ideologia da organização demandam forte lealdade a ela". Exemplos de trabalhos sensíveis ou remotos são: gerentes de subsidiária estrangeira, embaixadores, padres etc. 


\subsubsection{Design da Superestrutura}

O segundo grande grupo inclui dois parâmetros de design: agrupamento em unidades e tamanho da unidade. Chiavenato (1986, p. 245), dentro do princípio do agrupamento de atividades, menciona que "As funções devem ser designadas para as unidades orgânicas na base da homogeneidade no sentido de alcançar a operação mais eficiente e econômica". Mintzberg (2003, p. 59) identifica quatro efeitos importantes do agrupamento: 1) estabelece um sistema de supervisão comum entre posições e unidades; 2) requer posições e unidades para compartilhar recursos comuns; 3) cria medidas de desempenho comuns; e 4) encoraja o ajuste mútuo. Considerando tais efeitos, Mintzberg (2003, p. 60) faz esta afirmação: “[...] o agrupamento pode estimular em importante grau dois mecanismos importantes de coordenação - a supervisão direta e o ajuste mútuo - e pode formar a base para um terceiro mecanismo - a padronização dos outputs - ao fornecer medidas de desempenho comuns". O agrupamento em unidades, portanto, refere-se às bases escolhidas para o agrupamento das posições em unidades e estas, em outras unidades de ordem superior, que estabelecem sistema de supervisão comum, recursos comuns, medidas de desempenho comuns e encorajam o ajustamento mútuo (MINTZBERG, 2001, p.144).

Mintzberg (2003, p. 61-64) apresenta seis bases de agrupamento, a saber:

1. Agrupamento por conhecimento e habilidade. As posições podem ser agrupadas conforme o conhecimento especializado e as habilidades que as pessoas demonstram no trabalho. [...] O agrupamento pode também ser baseado por nível de conhecimento ou por habilidade [...];

2. Agrupamento por processo de trabalho e função. As unidades podem estar baseadas no processo ou atividade usado pelo trabalhador. [...] O trabalho pode também ser agrupado conforme sua função básica na organização [...];

3. Agrupamento por tempo. Os grupos podem também ser formados conforme o tempo em que o trabalho é feito [...];

4. Agrupamento por output. Aqui as unidades são formadas na base dos produtos que fabricam ou serviços que prestam [...];

5. Agrupamento por cliente. Os grupos podem também ser formados para lidar com diferentes tipos de cliente;

6. Agrupamento por local. Os grupos podem ser formados conforme as regiões geográficas em que a organização opera.

No entanto, Mintzberg (2003, p. 67) considera que essas bases podem ser resumidas em apenas duas: por mercado ${ }^{7}$ - bases de produto, cliente e local; e funcional - bases de conhecimento, habilidade, processo de trabalho e função. $\mathrm{O}$ agrupamento por tempo pode ocorrer em ambas as categorias. Em síntese, o autor menciona que:

\footnotetext{
${ }^{7}$ Para Mintzberg (2003, p. 67) 'mercado' é “[...] utilizado para se referir às organizações que visam e que não visam ao lucro. Qualquer organização existe para servir a algum mercado, seja formado dos cidadãos atendidos por uma força policial, os alunos de um sistema escolar ou dos clientes de uma empresa manufatureira”.
} 
$\mathrm{Na}$ verdade, temos a distinção fundamental entre agrupar as atividades por fins, pelas características dos mercados finais atendidos pela organização - produtos e serviços que vende, clientes a que atende e locais onde fornece -, ou por meios, as funções (incluindo processos de trabalho, habilidade e conhecimento) que utiliza para produzir seus produtos e serviços.

Vasconcelos \& Hemsley (1989, p. 40) realizam uma comparação entre as vantagens de organizações que se agrupam por função e aquelas que se agrupam por projetos - Quadro 8.

\section{Quadro 8 - Comparação entre a estrutura funcional pura e a estrutura por projeto pura}

\begin{tabular}{|c|c|c|}
\hline $\begin{array}{l}\text { Fatores de comparação } \\
\text { de vantagens }\end{array}$ & Vantagens da estrutura funcional pura & $\begin{array}{l}\text { Vantagens da estrutura por projeto } \\
\text { pura }\end{array}$ \\
\hline Abrangência & - $\quad$ Técnicos mais especializados & - $\quad$ Técnicos mais diversificados. \\
\hline $\begin{array}{l}\text { Capacitação técnica da } \\
\text { instituição }\end{array}$ & $\begin{array}{l}\text { - Troca de experiências entre os técnicos da } \\
\text { área evita duplicação de esforços e } \\
\text { aumenta a capacitação técnica da } \\
\text { instituição. } \\
\text { A maior preocupação com } \\
\text { aperfeiçoamento dos técnicos tende a } \\
\text { aumentar ainda mais a capacitação técnica. } \\
\text { - Mais fácil organizar a 'memória técnica'. }\end{array}$ & $\begin{array}{l}\text { - Contato contínuo com técnico de } \\
\text { outras áreas mostra ao indivíduo } \\
\text { as inter-relações entre sua } \\
\text { especialidade e as outras, } \\
\text { aumentando a capacidade da } \\
\text { instituição para desen-volver } \\
\text { projetos integrados. }\end{array}$ \\
\hline Qualidade dos projetos & - Qualidade técnica dos trabalhos é superior. & \\
\hline $\begin{array}{l}\text { Cumprimento dos } \\
\text { prazos dos projetos }\end{array}$ & & $\begin{array}{l}\text { - Melhor cumprimento dos prazos } \\
\text { dos projetos. }\end{array}$ \\
\hline Satisfação do técnico & $\begin{array}{l}\text { É maior: } \\
\text { - Por estar sempre em contato com técnicos } \\
\text { da mesma especialidade. } \\
\text { - Por causa da estabilidade do grupo de } \\
\text { trabalho. } \\
\text { - Por sentir uma maior preocupação do } \\
\text { chefe com o seu desenvolvimento. } \\
\text { - Por ser avaliado por um técnico } \\
\text { competente da sua própria especialidade. } \\
\text { - Pelo fato da carreira ser melhor definida. }\end{array}$ & $\begin{array}{l}\text { É maior: } \\
\text { - Por ter a oportunidade de } \\
\text { interagir com elemento de outras } \\
\text { áreas e aprender as diversas } \\
\text { especialidades. } \\
\text { Por poder interagir com maior } \\
\text { variedade de pessoas e situações } \\
\text { diferentes. }\end{array}$ \\
\hline Atendimento ao cliente & & $\begin{array}{l}\text { - É melhor por existir um único } \\
\text { indivíduo que cuida do projeto } \\
\text { como um todo. }\end{array}$ \\
\hline Uso de recursos & $\begin{array}{l}\text { - Utilização mais eficiente de recursos } \\
\text { humanos e materiais. }\end{array}$ & \\
\hline $\begin{array}{l}\text { Existência de um } \\
\text { principal responsável }\end{array}$ & $\begin{array}{l}\text { - Existe um responsável para cada grupo de } \\
\text { indivíduos de uma mesma especialidade: o } \\
\text { gerente funcional. }\end{array}$ & $\begin{array}{l}\text { - Existe um responsável por e para } \\
\text { cada projeto integrado. }\end{array}$ \\
\hline $\begin{array}{l}\text { Administração (demais } \\
\text { aspectos) }\end{array}$ & $\begin{array}{l}\text { - Mais fácil e mais eficiente, a nível das } \\
\text { áreas funcionais. }\end{array}$ & $\begin{array}{l}\text { - } \quad \begin{array}{l}\text { Mais fácil e mais eficiente, a } \\
\text { nível dos projetos integrados. }\end{array} \\
\end{array}$ \\
\hline
\end{tabular}

Fonte: Vasconcelos \& Hemsley (1989, p. 40).

O agrupamento por função é facilitado quando existem interdependências de processo (pessoas fazendo o mesmo tipo de trabalho, mas em fluxos diferentes), de escala (pessoal de manutenção) e, em menor grau, por motivos sociais. Um aspecto importante do agrupamento por função é o de encorajar a especialização, embora dois pontos negativos possam ser destacados: 1) diminui-se a atenção para um output mais amplo; 2) não se pode mensurar 
facilmente o desempenho. Estruturas burocráticas preferem bases funcionais: "Acima de tudo, ao procurarem racionalizar suas estruturas, tais burocracias preferem agrupar conforme os processos de trabalho usados e, depois, coordenar pela formalização do trabalho, envolvendo a proliferação de regras" (MINTZBERG, 2003, p. 73-74).

Já o agrupamento por mercado favorece a interdependência dos fluxos de trabalho, pois facilitam a realização de tarefas e é mais flexível para mudá-las de forma a servir aos mercados finais da organização. Organizações que utilizam a base de mercado tendem a apresentar estruturas menos burocráticas, pois sua ênfase não recai sobre a especialização. Em síntese, Mintzberg (2003, p. 75-77) conclui:

[...] ao escolher a base de mercado para agrupamento, a organização opta pela coordenação do fluxo de trabalho às expensas da especialização por processo e por escala. Assim, se as interdependências do fluxo do trabalho forem significativas e se não puderem ser facilmente acomodadas pela padronização, a organização deve tentar acomodá-las em um agrupamento baseado no mercado para facilitar a supervisão direta e o ajustamento mútuo.

O agrupamento em unidades também apresenta relação com a localização na organização. Mintzberg (2003, p. 78) destaca que evidências não científicas, coletadas por meio de organogramas publicados e semelhantes, sugerem que o agrupamento por mercado é mais comum em níveis mais elevados da linha intermediária do que em níveis inferiores.

O segundo parâmetro do grupo design da superestrutura é o tamanho da unidade. Mintzberg (2003, p. 80) trata esse parâmetro por meio de duas questões: 1) quantas pessoas devem subordinar-se a cada gerente? (amplitude de controle do gerente) e 2) qual deve ser o formato da superestrutura? (verticalizado - pequenas unidades e amplitudes de controle estreitas - ou plano - grandes unidades e amplitudes de controle maiores).

Dessa forma, o tamanho da unidade se refere ao número de pessoas (ou unidades) que fazem parte de apenas uma unidade. Esse conceito não se equivale ao de extensão de controle “[...] porque às vezes as unidades são mantidas pequenas [...]”, não sendo necessário um controle rigoroso de supervisão (MINTZBERG, 2001, p.146).

Bateman \& Snell (1998, p. 235) definem amplitude de controle como "O número de subordinados que se reportam diretamente a um executivo ou um a supervisor [...]". Estes autores consideram que uma amplitude de controle ótima maximiza a eficácia porque é: "(1) pequena o suficiente para permitir que os administradores mantenham controle sobre seus subordinados, mas (2) não tão pequena que conduza a um controle exagerado e número de gerentes excessivo para supervisionar um pequeno número de subordinados". Os autores identificam cinco fatores que favorecem a amplitude de controle ótima: 
(1) o trabalho é rotineiro, (2) os subordinados são altamente treinados, (3) o administrador é altamente capacitado, (4) os cargos são similares e as medidas de desempenho, comparáveis e (5) os subordinados preferem ter autonomia a um controle cerrado da supervisão.

Em suma, Mintzberg (2003, p. 86) conclui que o tamanho da unidade aumenta por: 1) padronização; 2) similaridade das tarefas desempenhadas; 3) necessidade dos funcionários por autonomia e auto-realização; e 4) necessidade de decréscimo da distorção do fluxo de informação hierarquia acima. Por outro lado, diminui por: 1) necessidade de supervisão direta acirrada; 2) necessidade de ajustamento mútuo entre tarefas interdependentes complexas; 3) extensão em que o gerente de uma unidade possui tarefas não de supervisão a desempenhar; e 4) necessidade de acesso freqüente dos membros da unidade ao gerente para consulta.

O tamanho da unidade também apresenta relação com a parte da organização. Assim, na base da entidade espera-se que esse tamanho seja maior, enquanto no topo, espera-se que seja menor. Concluindo, Mintzberg (2003, p. 88) tem a expectativa de que "[...] o núcleo operacional da organização assuma um formato plano, que a linha intermediária tenha formato de cone, com lados progressivamente íngremes, e que a tecnoestrutura e as unidades de apoio mais profissionais sejam mais verticalizadas".

\subsubsection{Design dos Vínculos Laterais}

O terceiro grupo envolve dois parâmetros: sistemas de planejamento e controle e instrumentos de interligação. Mintzberg (2003, p. 90) distingue dois tipos de sistemas de planejamento e controle: "[...] um que foca a regulação do desempenho global e outro que procura regular as ações específicas”. O primeiro é designado como 'controle de desempenho' uma vez que busca principalmente monitorar os resultados após a ocorrência desses, enquanto o segundo é designado como 'planejamento das ações', pois está orientado principalmente para as ações que irão ocorrer. A Figura 4 apresenta o relacionamento entre esses dois tipos.

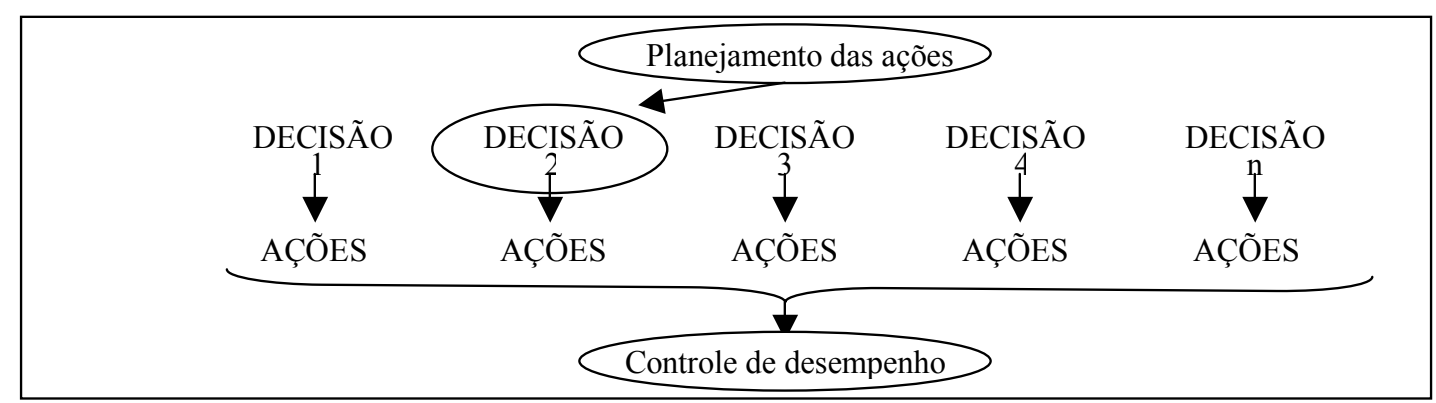

Figura 4 - Relacionamentos entre o planejamento das decisões e das ações e o controle de desempenho.

Fonte: Mintzberg (2003, p. 90). 
Tratando especificamente do processo de planejamento, Maximiano (1989, p. 82) considera que esse pode ser definido de várias maneiras, a saber:

- Um processo de definir objetivos ou resultados a serem alcançados, bem como as atividades e os recursos (meios) que permitirão alcançá-los;

- Interferir na realidade, com o propósito de passar-se de uma situação conhecida para uma outra situação desejada, dentro de um intervalo de tempo predeterminado;

- Tomar no presente decisões que afetam o futuro, visando reduzir sua incerteza.

Mintzberg (2003, p. 93-94) enumera dois pontos que devem ser observados sobre o planejamento das ações: 1) nem sempre respeita a autonomia da unidade, nem tampouco mapeia o sistema de agrupamento, ou seja, impõe decisões específicas e 2) por esse motivo, passa a ser uma forma menos pura de padronização dos outputs. Em suma, o autor faz a seguinte afirmação: “O planejamento das ações surge como o meio pelo qual as decisões e as ações não rotineiras de toda uma organização, tipicamente estruturada em base funcional, podem ser desenhadas como um sistema integrado". Assim, enquanto a padronização do comportamento desenha a organização como um sistema integrado para as atividades rotineiras, o planejamento das ações o faz para as ações não rotineiras.

Controlar, segundo Bateman \& Snell (1998, p. 29), significa monitorar o progresso das ações planejadas e implementar mudanças quando necessárias. Maximiano (1989, p. 273) considera que o processo de controle compreende as quatro etapas seguintes:

- Definição de um objetivo, alvo ou meta predeterminada;

- Alguma forma de mensuração da atividade que procura alcançar esse resultado esperado;

- Comparação entre a atividade (desempenho presente) e o objetivo (desempenho esperado);

- Algum tipo de ação que corrija ou reforce a atividade, para assegurar a realização do objetivo, ou que detecte a necessidade de alterá-lo.

Para Mintzberg (2003, p. 91) o controle de desempenho regula resultados globais. Assim, os sistemas de controle de desempenho são mais apropriados para organizações agrupadas por mercado, pois, dessa forma, existe pequena interdependência entre as unidades, requerendo que o desempenho seja regulado, ao invés das ações, como faz o planejamento, para atividades não rotineiras, e a formalização do comportamento, para atividades rotineiras. Ademais, tal fato é facilitado já que cada unidade apresenta um output diferente. Mintzberg (2003, p. 92-93) identifica dois propósitos do controle de desempenho: monitorar e motivar "Por um lado, podem ser usados simplesmente para sinalizar quando o desempenho de uma unidade estiver deteriorado. [...] Por outro lado podem ser usados para estimular desempenho superior". No entanto, destaca o autor, o aspecto motivacional traz alguns problemas: 
- o gerente pode fixar padrões baixos e facilmente alcançáveis e/ou distorcer informações de feedback enviadas ao Sistema de Informação Gerencial;

- a escolha do período de planejamento - não há vínculo direto entre os padrões de desempenho e as decisões específicas tomadas;

- padrões que não podem ser realizados, pois estão além do controle gerencial falência de um cliente importante.

Diferenciando entre controle de desempenho, planejamento das ações e formalização do comportamento, em termos de um continuum de regulação crescentemente rigorosa, Mintzberg (2003, p. 94) escreve:

- O controle de desempenho impõe padrões gerais de desempenho em determinado período de tempo, sem referência a ações específicas;

- O planejamento das ações impõe decisões e ações específicas a serem adotadas em pontos específicos do tempo;

- A formalização do comportamento impõe os meios pelos quais as decisões e as ações são adotadas.

Sistemas de planejamento e controle apresentam relação com a parte da organização. Mintzberg (2003, p. 98) considera que o planejamento das ações ocorre com maior freqüência na base da entidade, enquanto que, no topo da entidade, a tendência é o uso de controle de desempenho, principalmente quando as responsabilidades de uma unidade são globais.

O segundo parâmetro do grupo design dos vínculos laterais é designado como instrumentos de interligação. Consta em Mintzberg (2003, p. 99) que os instrumentos de interligação surgem para suprir importantes interdependências que permanecem mesmo após todos os cargos serem definidos, a superestrutura construída e os sistemas de planejamento e controle estabelecidos. Ainda, conforme esse autor, os instrumentos de interligação, até recentemente, eram deixados ao acaso ou apenas ocorriam informalmente, ou seja, fora da estrutura organizacional formal. Concluindo, afirma que recentemente, “[...] as organizações desenvolveram um conjunto de instrumentos para encorajar contatos de interligação entre indivíduos, instrumentos que podem ser incorporados na estrutura formal”.

Os instrumentos de interligação visam promover a integração entre as diversas partes da organização. Integração, como afirmam Bateman \& Snell (1998, p. 232), “[...] é o grau em que unidades diferenciadas trabalham juntas coordenando os seus esforços". Simeray (1977, p. 50) distingue entre dois tipos de ligações: uma formal, que corresponde basicamente às ligações de autoridade, e outra informal, que corresponde às ligações de cooperação.

Mintzberg (2003, p. 99-106) apresenta quatro tipos básicos de instrumentos de interligação, quais sejam: cargos de interligação, forças-tarefas e comitês permanentes, 
gerentes de integração e estrutura matricial. Cargos de interligação surgem quando existe grande necessidade de contato para coordenar o trabalho de duas unidades cuja autoridade é informal. Força-tarefa “[...] é um comitê formado para realizar uma tarefa específica, e logo após dissolvida". Por outro lado, comitês permanentes possuem caráter regular e representam um agrupamento interdepartamental que se reúnem com o objetivo de discutir assuntos de interesse comum. Gerentes de integração surgem diante da necessidade de mais coordenação por ajustamento mútuo e possuem autoridade formal. Por fim, estruturas matriciais utilizam ao mesmo tempo as duas bases de agrupamento - funcional e por mercado.

São diversos os inter-relacionamentos entre instrumentos de interligação e demais parâmetros de design apresentados até o momento. De forma resumida, essas relações são apresentadas a seguir tendo por base Mintzberg (2003, p. 108-110):

- podem ser utilizados com qualquer base de agrupamento, no entanto, merece destaque as que surgem freqüentemente em agrupamentos funcionais quando a orientação para o mercado é introduzida;

- quanto maior a utilização dos instrumentos de interligação, menor o tamanho médio das unidades organizacionais;

- alguns instrumentos de interligação, em especial a estrutura matricial, provocam um maior número de gerentes na organização;

- são destinados principalmente às estruturas orgânicas;

- são usados geralmente quando o trabalho é, ao mesmo tempo, horizontalmente especializado, complexo e altamente interdependente;

- os instrumentos de interligação e os sistemas de planejamento e controle, em alguma extensão, são mutuamente exclusivos.

Por fim, os instrumentos de interligação também apresentam relação com a parte da organização. Segundo Mintzberg (2003, p. 110), "Parece que os instrumentos de interligação estão mais bem ajustados ao trabalho executado nos níveis intermediários da estrutura, envolvendo muitos gerentes de linha, bem como especialistas de assessoria”.

\subsubsection{Design do Sistema de Tomada de Decisão}

Como último grupo de parâmetros tem-se o design do sistema de tomada de decisão no qual se inclui o parâmetro descentralização que está segmentado em vertical e horizontal. Para Maximiano (1989, p. 191) uma questão enfrentada pelas organizações em processo de 
remodelação ou crescimento é a de centralizar ou descentralizar o poder de decisão. Simeray (1977, p. 46) afirma que centralização "[...] consiste em reduzir os centros de decisão a um número mínimo e localizá-los próximos à Diretoria Geral”. Por outro lado, descentralização “[...] consiste em colocar os centros de decisão próximos aos órgãos de execução, multiplicando-se tanto quanto for necessário para dar à empresa uma eficiência máxima".

Mintzberg (2003, p. 112) sugere que uma estrutura pode ser caracterizada como centralizada quando todo o poder de tomada de decisão está situado em um único ponto da organização, de outra forma, quando o poder de tomada de decisão está disperso entre muitas pessoas, caracteriza-se como descentralizada. Mintzberg (2003, p. 113) afirma que a decisão de centralizar ou descentralizar decorre da questão 'divisão do trabalho versus coordenação', de forma semelhante ao que ocorre com a maioria dos problemas de estrutura, destacando ser a centralização a forma mais segura de manter a coordenação na tomada de decisão. Portanto, a necessidade de coordenação é a principal justificativa para a centralização. Dentro desse contexto, surge a seguinte questão: por que, então, uma organização iria descentralizar seu processo de tomada de decisão? A resposta de Mintzberg reside no fato de que nem todas as decisões podem ser entendidas por uma única pessoa, ou por um único centro. Acrescenta também que a descentralização possibilita à organização - considerando as condições locais mais agilidade em suas respostas, sendo, assim, um estímulo para a motivação.

Mintzberg (2003, p. 116) identifica dois pontos importantes relacionados aos conceitos de centralização e descentralização, a saber: 1) a centralização e a descentralização devem ser tratadas como extremos de um continuиm e 2) a discussão quanto ao significado dos conceitos de centralização e descentralização decorre da presença de conceituações diferentes que buscam ser reconhecidos sob o mesmo rótulo. Com base nos conceitos identificados por Mintzberg (2003, p. 119-132), dois parâmetros de design se distinguem: descentralização vertical e descentralização horizontal. A primeira “[...] diz respeito à delegação do poder de tomada de decisão aos escalões inferiores da cadeia de autoridade [...]”. A segunda representa “[...] a transferência de poder dos gerentes para os não-gerentes [...]”. Esses dois parâmetros podem ser encontrados em pelo menos seis formas, como apresenta Mintzberg (2001, p.149):

(1) centralização vertical e horizontal, no qual todo o poder reside no ápice estratégico; (2) descentralização horizontal (seletiva), na qual o ápice estratégico compartilha o poder com a tecnoestrutura que padroniza o trabalho de todas as outras pessoas; (3) descentralização vertical limitada (paralela), na qual os gerentes de unidades baseadas no mercado recebem a delegação de poder para controlar a maioria das decisões relativas às suas unidades de linha; (4) descentralização vertical e horizontal, na qual a maior parcela de poder reside na essência operacional, na parte inferior da estrutura; (5) descentralização vertical e horizontal seletiva, na qual o poder sobre as várias decisões é dispersado para vários locais na organização [...] e (6) descentralização pura, na qual o poder é compartilhado de modo relativamente igual por todos os membros da organização. 
Mintzberg (2003, p. 135-136) apresenta a seguir como ocorre o relacionamento entre a descentralização e os demais parâmetros de design:

- formalização do comportamento - retira poder formal dos operadores e dos gerentes que os supervisionam e o concentra próximo ao topo da hierarquia de linha e na tecnoestrutura, centralizando a organização em ambas as dimensões;

- treinamento e doutrinação - desenvolvem especialização abaixo da linha intermediária, descentralizando a estrutura em ambas as dimensões;

- agrupamento por mercado - leva à descentralização vertical limitada ou paralela;

- agrupamento funcional, tamanho da unidade e amplitude de controle - nenhuma conclusão definitiva pode ser tirada;

- sistemas de planejamento e controle - em geral, emergem como parâmetros de design ao efetivarem centralização modesta ou extensiva;

- instrumentos de interligação - são usados principalmente para coordenar o trabalho dentro e entre as constelações de trabalho seletivamente descentralizadas.

A descentralização também apresenta relação com a parte da organização. Mintzberg (2003, p. 137) menciona que "Por definição, a descentralização vertical envolve apenas a cadeia de autoridade - isto é, a cúpula estratégica e a linha intermediária”. Por outro lado, também "Por definição, a descentralização horizontal traz as outras três partes da organização - a tecnoestrutura, a assessoria de apoio e o núcleo operacional - para o sistema de poder".

\subsubsection{Fatores Situacionais}

Considerados os mecanismos de coordenação, as partes-chave da organização e os parâmetros de design, são apresentados neste tópico os fatores situacionais, quais sejam: idade e tamanho, sistema técnico, ambiente e poder. Mintzberg (2003, p. 139) afirma que fatores situacionais são “[...] os estados ou as condições organizacionais que estão associados ao uso de certos parâmetros de design". Esse autor os analisa por meio de um conjunto de hipóteses em que relaciona um dos fatores situacionais a pelo menos um parâmetro de design.

O primeiro fator situacional é idade e tamanho. Com base nas evidências sobre seus efeitos, Mintzberg (2003, p. 141-145) identifica cinco hipóteses, sendo duas referentes à idade e as demais ao tamanho. A primeira dispõe que quanto mais antiga a organização, mais formalizado é seu comportamento. Essa hipótese sugere que, permanecendo os demais fatores constantes, à medida que a organização envelhece, de tanto as mesmas atividades serem 
repetidas, tornam-se previsíveis de tal forma que é possível formalizá-las. A segunda hipótese preceitua que a estrutura reflete a época de origem do setor. Segundo constatações de Arthur Stinchcombe, existe um relacionamento entre idade do setor e especialização das tarefas, além da utilização de profissionais treinados em cargos de assessoria.

A terceira hipótese - relacionada com tamanho - destaca que quanto maior a organização, mais elaborada é sua estrutura, isto é, quanto mais especializadas as tarefas, mais diferenciadas as unidades e mais desenvolvido o componente administrativo. Essa hipótese sugere que uma empresa, quando cresce, tende a especializar o trabalho de forma que, dentro das unidades, esse se torne homogêneo, enquanto que entre as unidades, torne-se mais diferenciado. Tal fato requer a utilização de mecanismos de coordenação mais complexos. A quarta hipótese, por sua vez, estabelece que quanto maior a organização, maior o tamanho médio de suas unidades. Com o aumento da organização, conforme visto, as unidades passam a realizar trabalhos homogêneos, o que possibilita a utilização de supervisão direta ou mesmo padronização dos processos de trabalho, gerando uma amplitude de controle maior. Por fim, a quinta hipótese dispõe que quanto maior a organização, mais formalizado será seu comportamento. O aumento no tamanho da organização conduz à repetição das atividades, tornando-as previsíveis e passíveis de formalização. A Figura 5 mostra o que ocorre quando o tamanho da organização aumenta, permanecendo constante os demais fatores situacionais.

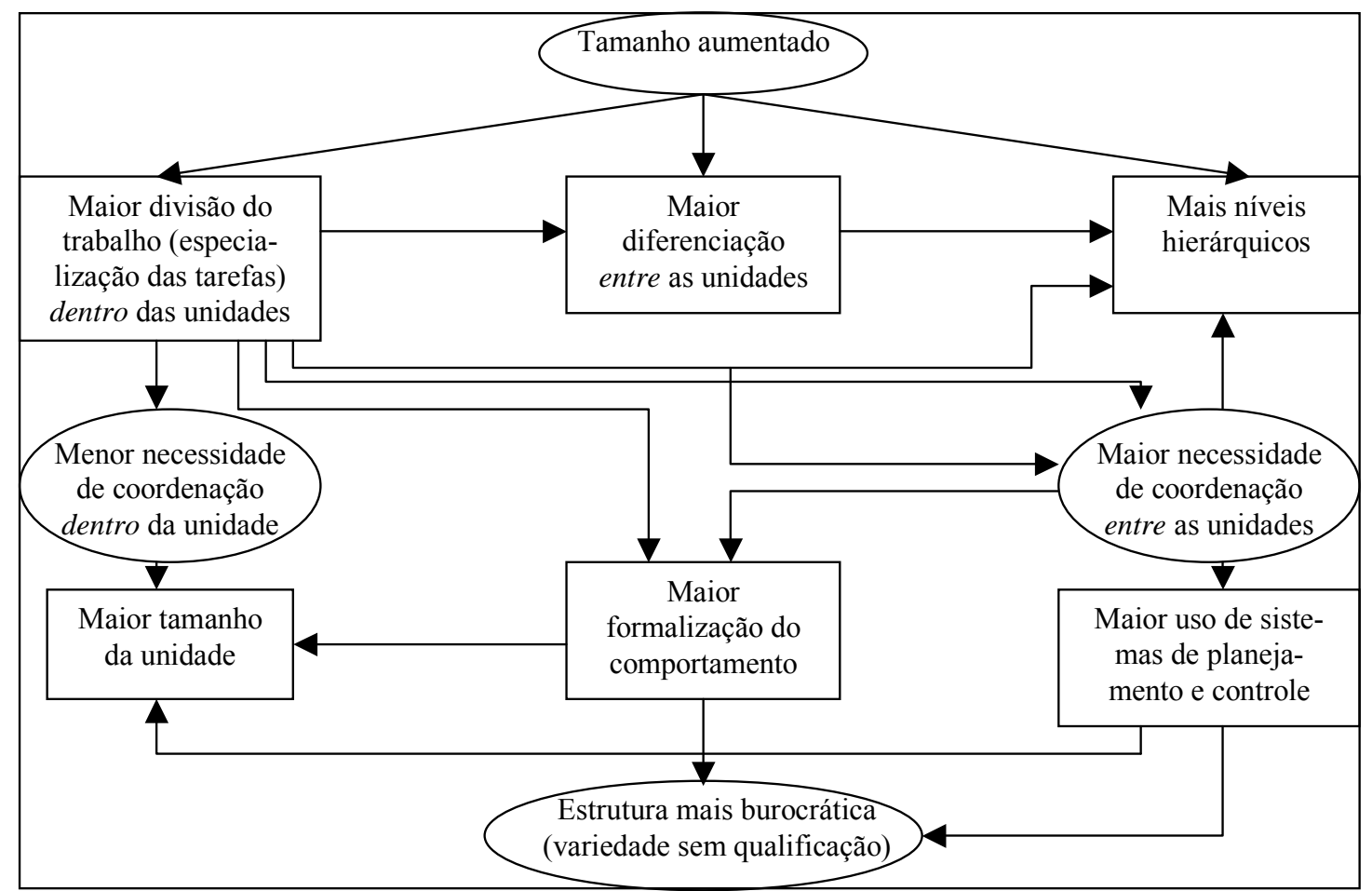

Figura 5 - Relacionamentos entre tamanho e estrutura organizacional.

Fonte: Mintzberg (2003, p. 145). 
O segundo fator situacional é o sistema técnico. Refere-se aos instrumentos utilizados no núcleo operacional para transformar inputs em outputs, não coincidindo com tecnologia base de conhecimentos de uma organização. Mintzberg (2003, p. 153-155) identifica três hipóteses relacionadas com esse fator. A primeira destaca que quanto mais regular o sistema técnico - dividido em tarefas simples e especializadas, tornando desnecessário o julgamento de quem o opera -, mais formalizado o trabalho operacional e mais burocrática a estrutura do núcleo operacional. Essa hipótese sugere que sendo o sistema técnico regular, o trabalho realizado no núcleo operacional torna-se rotineiro e previsível, possibilitando a especialização e a formalização. O mecanismo de coordenação favorecido é a padronização dos processos de trabalho. A segunda hipótese dispõe que quanto mais sofisticado for o sistema técnico, mais elaborada será a estrutura - não operacional. Devido à complexidade do sistema técnico, torna-se necessário a contratação de especialistas de assessoria que dominem o funcionamento desse sistema. Esses assessores terão liberdade para tomar decisões e tenderão a trabalhar entre si por meio de forças-tarefa. Por fim, a terceira hipótese destaca que a automação do núcleo operacional transforma uma estrutura burocrática em orgânica, o que dispensa a regulação das atividades do núcleo operacional, mas requer especialistas da assessoria de apoio competentes no manuseio do sistema técnico. Esses profissionais procuram se comunicar por meio de instrumentos de interligação, o que tende a tornar a estrutura orgânica.

O terceiro fator situacional é o ambiente. Enquanto os dois outros fatores são intrínsecos à entidade, esse representa o meio no qual a entidade atua, relacionado-se às várias características do contexto externo da organização, tais como mercado, clima político, condições econômicas etc. Mintzberg (2003, p. 155-156) identifica quatro dimensões do ambiente organizacional: 1) estabilidade - pode variar de estável a dinâmico, no sentido de previsibilidade ou não do ambiente; 2) complexidade - pode variar de simples a complexo, no sentido da base de conhecimento necessária para atuar no ambiente; 3) diversidade de mercado - os mercados podem ir de integrados a diversificados, podendo a diversidade decorrer de variedade de clientes, produtos, serviços e áreas geográficas em que os outputs são vendidos; e 4) hostilidade - o ambiente pode variar de hostil a magnânimo.

São cinco as hipóteses enumeradas por Mintzberg (2003, p. 157-163) relacionadas ao ambiente. A primeira dispõe que quanto mais dinâmico o ambiente, mais orgânica a estrutura. Sendo estável o ambiente, a entidade tem maior possibilidade de prever condições futuras e padronizar as atividades realizadas no núcleo operacional ou mesmo em toda a estrutura da organização, mantendo-se constantes as demais condições. Por outro lado, não sendo estável, 
não é possível prever condições futuras e, por conseqüência, padronizar atividades, o que conduz a uma estrutura orgânica. A segunda hipótese ressalta que quanto mais complexo o ambiente, mais descentralizada a estrutura. Sendo o ambiente de difícil compreensão, o poder de tomada de decisão é distribuído hierarquia abaixo, podendo chegar ao núcleo operacional. A terceira hipótese dispõe que quanto mais diversificados os mercados da organização, maior é a propensão de ela dividir-se em unidades baseadas no mercado. Essa hipótese sugere que quando a organização é capaz de identificar mercados diferentes, seja de produtos, de clientes, dentre outros, ela tenderá a se dividir em unidades de alto nível, transferindo parcela do poder de decisão aos gerentes das unidades. Tal fato só não será possível quando o sistema técnico não for divisível ou se existir outro fator crítico que impossibilite a completa divisão. A quarta hipótese estabelece que a hostilidade extrema no ambiente leva qualquer organização a centralizar temporariamente sua estrutura. A hostilidade faz com que a organização centralize decisões em uma única pessoa, como forma de obter respostas rápidas e integradas. Por fim, a quinta hipótese conjetura que as disparidades no ambiente encorajam a organização a se descentralizar seletivamente em constelações de trabalho diferenciadas. Disparidades ambientais - um ambiente dinâmico, complexo, diversificado e hostil simultaneamente exigem que a entidade dê respostas diferentes. Para tanto, torna-se necessário que a organização diferencie sua estrutura de forma a criar constelações de trabalho em que cada qual será responsável em responder a um dos aspectos ambientais.

Considerando as duas primeiras hipóteses relacionadas ao ambiente, são identificados quatro tipos diferentes de estruturas cujas características estão resumidas no Quadro 9.

\section{Quadro 9 - Matriz de relação entre estabilidade e complexidade do ambiente}

\begin{tabular}{|l|l|l|}
\hline & \multicolumn{1}{|c|}{ Estável } & \multicolumn{1}{|c|}{ Dinâmico } \\
\hline Complexo & $\begin{array}{l}\text { Descentralizado } \\
\text { Burocrático } \\
\text { (padronização das habilidades) }\end{array}$ & $\begin{array}{l}\text { Descentralizado } \\
\text { Orgânico } \\
\text { (ajustamento mútuo) }\end{array}$ \\
\hline Simples & $\begin{array}{l}\text { Centralizado } \\
\text { Burocrático } \\
\text { (padronização dos processos de de } \\
\text { trabalho) }\end{array}$ & $\begin{array}{l}\text { Orgânico } \\
\text { (supervisão direta) }\end{array}$ \\
\hline
\end{tabular}

Fonte: Mintzberg (2003, p. 164)

Como último fator situacional tem-se o poder. A organização pode não adotar a estrutura que seria recomendada pelos demais fatores situacionais porque fatores de poder podem conduzir a uma estrutura diferente. São três as hipóteses identificadas por Mintzberg (2003, p. 166-171) decorrentes de suas constatações acerca desse fator situacional. A primeira destaca que quanto maior o controle externo da organização, mais centralizada e formalizada 
sua estrutura. Evidências demonstram que a existência desse tipo de controle faz com que a entidade concentre poder de decisão em seu topo e, ademais, passe a confiar, mais do que o usual, em normas e regulamentos. O controle externo também cria preocupações extras quanto às ações tomadas, tendo em vista a necessidade de prestar contas ao público externo. Uma outra conseqüência de tal controle é a ação que exerce no sentido de tornar burocrática a estrutura da entidade, à medida que demandas são impostas a fim de racionalizar as ações. A segunda hipótese dispõe que as necessidades de poder dos membros da organização tendem a gerar estruturas excessivamente centralizadas. Embora todos os membros busquem poder, a consecução de poder excessivo possibilita a centralização da estrutura da entidade. Por fim, a terceira hipótese estabelece que a moda - poder das normas culturais em que a organização está inserida - favorece a estrutura do dia, às vezes, mesmo quando inapropriada.

Percebe-se que tanto os parâmetros de design como os fatores situacionais apresentados por Mintzberg $(2001,2003)$ foram tratados, em grande parte, pelas demais abordagens - de forma isolada, ou considerando-se a dependência de alguns com outros.

O tópico seguinte apresenta resumidamente as tipologias de estruturas organizacionais consultadas e, de forma mais detalhada, a tipologia de estruturas organizacionais dentro da abordagem da configuração de estruturas organizacionais.

\subsection{Tipologias das Estruturas Organizacionais}

Analisando as Teorias Organizacionais, percebe-se que as entidades atuam em ambientes diferentes e possuem características internas também distintas. Com base nessas diferenças, teóricos da administração apresentam tipologias de estruturas organizacionais. Blau \& Scott (1970, p. 58-71) referem-se a quatro tipos de organizações tendo por base a identificação do principal beneficiário de suas operações, a saber: 1) 'associações de benefício mútuo', nas quais o principal beneficiário é o quadro social (ex. partidos políticos, sindicatos, associações profissionais etc.); 2) 'firmas comerciais', onde os proprietários são os principais beneficiários (ex. indústrias, lojas de atacado e varejo, bancos etc.); 3) 'organizações de serviços', em que o grupo de clientes é o principal beneficiado (ex. agências de serviço social, escolas, hospitais etc.); e 4) 'organizações de bem-estar público', nas quais o principal beneficiado é o grande público (ex. departamento de Estado, divisão de imposto de renda, pesquisadores, dentre outros). De acordo com essa tipologia, a organização filantrópica é um misto entre 'associação de benefício mútuo' e 'organizações de serviços', pois servem aos interesses de seus membros servindo aos interesses de outros. 
Uma segunda tipologia é proposta por Simeray (1977, p. 103-118) que classifica as organizações pelo tamanho. Esse autor reconhece que tal critério não é o único determinante da estrutura organizacional, mas por ser um critério sintético "[...] permite o exame progressivo dos tipos possíveis de estruturas, exame esse que completará os demais critérios propostos”. São identificados cinco tipos de estruturas: 1) microempresa ou empresa artesanal, que representa o primeiro estágio de desenvolvimento; 2) pequena empresa; 3) média empresa; 4) grande empresa; e 5) empresa gigante. De forma resumida, o Quadro 10 apresenta os tipos de estrutura em função do tamanho e sua característica principal.

\section{Quadro 10 - Tipos de estruturas em função do tamanho e sua característica principal}

\begin{tabular}{|l|l|}
\hline Tipos de estrutura & Característica principal \\
\hline Microempresa ou Empresa Artesanal & Hierárquica \\
\hline Pequena Empresa & Linha e Assessoria \\
\hline Média Empresa & Hierárquica por Função \\
\hline Grande Empresa & Funcional ou Hierárquica por Função (ou uma ou outra) \\
\hline Empresa Gigante & Linha e Assessoria \\
\hline Fonte: Simeray (1977, p. 118). &
\end{tabular}

Uma terceira tipologia é identificada por Vasconcelos \& Hemsley (1989) que apresentam três tipos de estruturas organizacionais. A primeira é formada por estruturas tradicionais nas quais predominam princípios propostos pela Abordagem Clássica. A segunda é composta por estruturas inovativas ou orgânicas, mais apropriadas para ambientes dinâmicos e tarefas complexas. Por fim, têm-se estruturas matriciais que, conforme os autores, surgem “[...] como uma solução devido à inadequação da estrutura funcional para as atividades integradas, isto é, aquelas que para serem realizadas exigem interação entre as áreas funcionais" VASCONCELOS \& $\operatorname{HEMSLEY~(1989,~p.~51).~}$

Moraes (1994), estudando características organizacionais de grandes empresas brasileiras, não encontrou uma estrutura organizacional predominante, mas uma grande variedade, nas quais identificou certos tipos básicos: funcionais, divisionais, e unidades estratégicas de negócios. Outros tipos estruturais foram encontrados, a saber: simples, matriciais e holding. Machado-da-Silva \& Fonseca (1994), por sua vez, estudando o arranjo formal em organizações do setor calçadista de Novo Hamburgo (RS), identificaram três estágios básicos de estruturas organizacionais: empreendimento, formalização e flexibilização. $83 \%$ das organizações pesquisadas possuíam características predominantes dos estágios empreendimento e formalização. 


\subsubsection{Tipologia da Configuração das Estruturas Organizacionais}

Este tópico apresenta a tipologia da configuração de estruturas organizacionais proposta por Mintzberg (2003, p. 12), cuja premissa é que toda atividade humana organizada dá origem a duas exigências fundamentais e opostas, que são: divisão do trabalho em várias tarefas a serem executadas e coordenação dessas tarefas para a realização das atividades. Assim, a estrutura de uma organização pode ser definida por essas duas exigências básicas, que, no entanto, envolvem diversos parâmetros de design e fatores situacionais. Dentro desse contexto, Mintzberg (2001, p. 141) considera que fatores situacionais e parâmetros de design devem ser agrupados para a determinação da estrutura organizacional de uma entidade eficaz, devendo, entretanto, haver consistência entre eles. Desse agrupamento, emerge o principal mecanismo de coordenação e a parte-chave da organização. Portanto, a depender das escolhas dos fatores situacionais e dos parâmetros de design, um número ilimitado de estruturas organizacionais poderiam existir. Entretanto, Mintzberg (2003, p. 13), considera que, na prática, um número limitado de estruturas organizacionais explica grande parte "[...] das tendências que levam as organizações eficazes a estruturar-se por si mesmas”. De outra forma, o autor afirma que "[...] o design de uma estrutura organizacional eficaz [...] parece envolver a consideração de apenas algumas configurações básicas”.

Como conseqüência, Mintzberg $(2001 ; 2003)$ identifica seis estruturas organizacionais básicas, que são: estrutura simples, burocracia mecanizada, burocracia profissional, forma divisionalizada, adhocracia e missionária. Cada uma é caracterizada por um mecanismo de coordenação privilegiado, por uma parte-chave da organização predominante, e por parâmetros de design e fatores situacionais que lhes são específicos. Dessa forma, pode-se estabelecer uma relação entre os mecanismos de coordenação, as partes-chave da entidade e as estruturas organizacionais propostas por Mintzberg - Quadro 11.

\section{Quadro 11 - As seis configurações básicas - teoria de Mintzberg}

\begin{tabular}{|l|l|l|}
\hline Configuração estrutural & \multicolumn{1}{|c|}{ Principal mecanismo de coordenação } & \multicolumn{1}{c|}{ Parte-chave da entidade } \\
\hline Estrutura simples & Supervisão direta & Cúpula estratégica \\
\hline Burocracia mecanizada & Padronização dos processos de trabalho & Tecnostrutura \\
\hline Burocracia Profissional & Padronização das habilidades & Núcleo operacional \\
\hline Forma divisionalizada & Padronizção dos outputs & Linha intermediária \\
\hline Adhocracia & Ajustamento mútuo & Assessoria de apoio \\
\hline Missionária & Padronização das normas & Ideologia \\
\hline
\end{tabular}

Fonte: Adaptado de Mintzberg (2003, p. 174).

Segundo Mintzberg (2003, p. 178-182) a estrutura simples caracteriza-se por não apresentar estrutura bem elaborada. Assim, sua estrutura ou inexiste ou é pequena, exigindo 
poucos assessores de apoio, pouca diferenciação entre unidades e pequena hierarquia gerencial. Além disso, há nela pouca formalização do comportamento, pouca utilização de planejamento e controle, pouco treinamento e doutrinação e pouca utilização de instrumentos de interligação. Dessa forma, o que emerge desse tipo é uma estrutura orgânica cujo principal mecanismo de coordenação é a supervisão direta, tendo em vista a centralização, horizontal e vertical, do poder de tomada de decisões no topo da entidade. A cúpula estratégica surge como parte-chave da organização.

Basicamente, a estrutura simples é composta de uma pessoa na cúpula estratégica e um núcleo operacional orgânico, resultando em uma grande amplitude de controle da cúpula estratégica. $\mathrm{O}$ agrupamento nas unidades, quando existe, costuma ocorrer em base funcional, sendo a coordenação entre as funções exercida por quem está no topo. Há expressiva comunicação informal entre executivo principal e núcleo operacional, onde as tarefas exercidas tendem a ser pouco especializadas e interligadas, sendo o fluxo de trabalho flexível. Como há à centralização na tomada de decisão, as respostas tendem a ser rápidas. As estratégias são formuladas pelo principal executivo e são marcadas pela intuição, refletindo assim a visão implícita desse executivo.

Quanto aos fatores situacionais, o ambiente de uma estrutura simples tende a ser, de forma simultânea, simples e dinâmico. Enquanto o simples permite que uma única pessoa detenha o controle em suas mãos, o ambiente dinâmico permite que a estrutura seja orgânica, pois sua condição futura é imprevisível e a coordenação não pode ser feita por meio de padronização. O sistema técnico tende a ser pouco sofisticado e não regulamentado, tornandose desnecessária a existência de assessores de apoio, assim como - por não ser regulamentado - não exige burocratização do núcleo operacional. A nova organização tende a adotar uma estrutura dessa natureza, independentemente de seu ambiente, por não haver tempo suficiente para a elaboração da estrutura administrativa. Assim, enquanto a maior parte das organizações passa pela estrutura simples em seus primeiros anos, as pequenas organizações permanecem como estrutura simples. A existência de hostilidade, necessidades pessoais e pouco controle externo também favorecem esse tipo de estrutura.

Mintzberg (2003, p. 186-198) afirma que burocracias mecanizadas possuem tarefas rotineiras e altamente especializadas, em sua dimensão horizontal e vertical, no núcleo operacional. Portanto, possuem alta formalização do comportamento - principal parâmetro de design - e padronização dos processos de trabalho no núcleo operacional por meio de normas, regulamentos e comunicação formalizada em toda a organização. Há pouca exigência de treinamento e doutrinação. O principal mecanismo de coordenação é a padronização dos 
processos de trabalho, o que faz com que a tecnoestrutura seja a parte-chave da organização. A divisão do trabalho e a diferenciação entre unidades são fortemente enfatizadas. Essas unidades são grandes no nível operacional, pois a formalização do comportamento permite que um supervisor possa ter sob seu controle muitos operários. A base funcional é utilizada como critério de agrupamento das tarefas e poucos instrumentos de interligação são utilizados. O poder de decisão é centralizado verticalmente e descentralizado de forma limitada em sua dimensão horizontal, pois a tecnoestrutura emerge como parte-chave por ser a responsável pela padronização do trabalho. A estrutura administrativa é elaborada de tal forma que é nítida a distinção entre linha e assessoria, sendo a estratégia elaborada de cima para baixo com ênfase, principalmente, no planejamento de ações.

Quanto aos fatores situacionais, considera-se que burocracias mecanizadas ocorrem em ambientes simples e estáveis. A simplicidade permite a previsão de condições futuras, o que leva à centralização. Por outro lado, a estabilidade leva à repetição que permite a padronização dos processos de trabalho, o que faz com que a tecnoestrutura surja como parte principal e divida o poder de tomada de decisão com a cúpula estratégica. Quanto à idade e ao tamanho, surgem em organizações maduras e grandes, de tal forma que o volume de trabalho operacional é suficiente para levar à repetição e à padronização, permitindo padrões bem estabelecidos. Portanto, representam o segundo estágio de desenvolvimento estrutural, sendo o resultado de estruturas simples que crescem e envelhecem. O sistema técnico é caracterizado por ser regulamentado, desde que sejam capazes de estabelecer rotinas no trabalho, além de formalizá-lo. O controle externo sobre organizações dessa natureza é presente. Por fim, a moda não é atuante na definição da burocracia mecanizada.

A terceira estrutura organizacional identificada por Mintzberg (2003, p. 212-229) é a burocracia profissional. Nesse tipo de entidade, o trabalho operacional é estável, o que permite prever ou predeterminar o comportamento. Por outro lado, o trabalho executado é complexo, o que faz com que os próprios operadores tenham o controle. O mecanismo de coordenação favorecido deve padronizar o comportamento e descentralizar o poder de tomada de decisão, o que faz emergir a padronização das habilidades como tal. O parâmetro de design principal é o treinamento e, de forma complementar, a doutrinação. O núcleo operacional surge como parte-chave da organização, o que inverte o fluxo de informações, ou seja, flui de baixo para cima. Pouca padronização do comportamento é utilizada devido à complexidade do trabalho executado, o que faz com que a tecnoestrutura seja pouco elaborada. No mesmo sentido, há ampliação vertical das tarefas, permanecendo, entretanto, a especialização horizontal, dada a presença de profissionais. Sua estrutura é, ao mesmo tempo, funcional e por 
mercado, pois decorre tanto da especialização funcional dos profissionais quanto dos próprios clientes que buscam profissionais com a especialidade por eles requerida. Sistemas de planejamento e controle são pouco utilizados. A assessoria de apoio é bem elaborada devido à necessidade de execução das tarefas rotineiras. Ademais, os profissionais necessitam de poder para tomada de decisão a fim de executarem suas tarefas complexas. Assim, a descentralização existente ocorre tanto em sua dimensão vertical quanto na horizontal.

O ambiente característico das burocracias profissionais é complexo e estável. É complexo porque a sua aprendizagem pelos profissionais só ocorre por meio de treinamento, o que requer descentralização para que possam exercer suas atividades, e é estável porque permite a previsibilidade e, por conseqüência, a padronização das habilidades. Os fatores de idade e tamanho não são muito significativos, já que se pode encontrar organizações profissionais com idades e tamanhos variados. O sistema técnico não é muito regulamentado, tampouco é sofisticado e automatizado, o que poderia transferir poder aos assessores de apoio. Destaca-se a diferença entre a base de conhecimento necessária para executar as tarefas e o sistema técnico, pois aquela é complexa, de difícil entendimento, enquanto esse é simples. Por fim, estruturas dessa natureza estão sujeitas ao modismo.

A forma divisionalizada, conforme Mintzberg (2003, p. 240-258), caracteriza-se como sendo uma estrutura incompleta, isso porque cada divisão tem sua própria estrutura. Como principal parâmetro de design, tem-se a confiança dispensada ao agrupamento por mercado na linha intermediária. Tal fato minimiza a interdependência entre divisões, tendo em vista a relativa autonomia que recebem. O escritório central é responsável, dentre outras coisas, pela coordenação das divisões, o que faz com que a amplitude de controle na cúpula estratégica seja extensa. Dessa forma, ocorre descentralização do poder de tomada de decisão, ou seja, a cúpula estratégica o transfere em parte às divisões, caracterizando a descentralização vertical limitada (chega apenas aos gerentes intermediários) e paralela (ocorre entre os gerentes intermediários). Horizontalmente, no entanto, é centralizada. Para que o núcleo estratégico possa manter o controle das diversas divisões sem lhes retirar a autonomia, a padronização dos outputs emerge como principal mecanismo de coordenação. Para tanto, o sistema de controle de desempenho é bastante desenvolvido, sendo assim, outro parâmetro de design importante. Pouca padronização do comportamento, pouco planejamento de ações e poucos instrumentos de interligação são utilizados como forma de evitar a redução de autonomia das divisões. Existe, entretanto, alguma especialização de tarefas entre as divisões e o escritório central, em suas duas dimensões. Os gerentes intermediários representam a parte-chave da organização e são treinados pelo próprio escritório central, como forma de padronizar suas 
habilidades gerenciais e, de forma semelhante, são doutrinados. O fluxo de decisões flui de baixo para cima e existe nítida divisão do trabalho entre escritório central e divisões. As divisões, para que a estrutura divisionalizada possa funcionar melhor, geralmente, são estruturadas como burocracias mecanizadas.

O fator situacional mais importante é a diversidade de mercado, o que vem permitir a divisão. Para que tal ocorra, no entanto, é necessário que o sistema técnico possa ser segmentado, de forma que cada divisão tenha o seu de forma eficiente. Organizações dessa natureza funcionam melhor em ambientes que não sejam nem muito complexos nem muito dinâmicos, tal como uma burocracia mecanizada. Quanto ao tamanho e à idade, a forma divisionalizada costuma surgir em organizações que crescem de tal forma que necessitam de novos mercados ou que envelhecem e necessitam de outros mercados que não os tradicionais, estrutura que pode ser considerada o terceiro estágio de desenvolvimento.

Mintzberg (2003, p. 282-305) apresenta a estrutura organizacional adhocrática como sendo a que melhor se adapta à inovação sofisticada e também a mais complexa. Sua estrutura é altamente orgânica, possui pouca formalização do comportamento, apresenta especialização do trabalho em sua dimensão horizontal, tendo o treinamento formal como meio para tanto. A tendência é que seus especialistas estejam agrupados em base funcional tendo em vista propósitos internos, sendo divididos em pequenas equipes de projeto, baseadas no mercado, com o objetivo de desenvolver trabalho específico. Confia fortemente em instrumentos de interligação para encorajar o ajustamento mútuo que emerge como principal mecanismo de coordenação. O poder de tomada de decisão é descentralizado vertical e horizontalmente, sendo que de forma seletiva. Considerando que a inovação é sua característica principal, também é conhecida como organização inovadora na qual a padronização não é possível. Pouco planejamento de ações é utilizado para que se mantenha a flexibilidade da organização em responder de forma criativa às suas demandas. As informações não possuem qualquer padrão formal, ou seja, fluem de forma flexível e informal, o que faz com que a unidade de comando praticamente inexista. Para funcionarem bem, necessitam de especialistas, isto é, de profissionais que obtêm seu conhecimento e habilidade por meio de treinamento, sendo que, os conhecimentos e habilidades não existem, nessa estrutura, para serem padronizados, mas para produzirem novos conhecimentos e habilidades. Para tanto, adhocracias utilizam diversos especialistas de áreas diferentes que se unem para desenvolver projetos de inovação específicos e que têm sua coordenação por meio de ajustamento mútuo que, dessa forma, emerge como principal mecanismo de coordenação. 
A adhocracia pode ser operacional ou administrativa. A operacional tem por principal objetivo inovar e resolver problemas de interesse dos clientes, o que faz com que trabalhos administrativo e operacional se confundam, de forma que a parte-chave seja o núcleo operacional. A administrativa se caracteriza por assumir projetos em benefício próprio, existindo nítida distinção entre trabalho administrativo e operacional, ficando o núcleo operacional separado das demais partes, com a assessoria de apoio como parte-chave.

$\mathrm{O}$ ambiente em que atuam adhocracias é dinâmico e complexo. O ambiente dinâmico não permite a previsibilidade, o que requer uma estrutura orgânica, e o complexo exige descentralização. Considerando que organizações dessa natureza não são estáveis, tendem a permanecerem atuando por pouco tempo e, assim, são jovens. À medida que envelhecem tendem a se tornar burocracias, de forma que, também estão associadas ao primeiro estágio de desenvolvimento das organizações. O sistema técnico é muito sofisticado e freqüentemente automatizado, no caso da adhocracia administrativa, e não regulado e simples, na adhocracia operacional. Por fim, a moda é uma condição necessária para a existência das adhocracias.

A última configuração apresentada por Mintzberg (2001, p. 155-156) é a missionária. Como as demais, apresenta uma combinação entre parâmetros de design e fatores situacionais distinta. Essas organizações são dominadas por sua ideologia que emerge como parte-chave da organização. Para tanto, o parâmetro da doutrinação é altamente utilizado, fazendo com que o principal mecanismo de coordenação seja a padronização das normas ou socialização, através da qual um novo membro, tendo assimilado as crenças e valores da entidade, terá liberdade para tomar decisões, o que faz com que surja a mais pura forma de descentralização. Apresenta pouca divisão de trabalho, pouca especialização de tarefas em suas duas dimensões (rotatividade das tarefas), pouca diferenciação entre suas partes, pouca formalização do comportamento, pouco uso de planejamento e controle, e pouca utilização de treinamento profissional. Por outro lado, muita comunicação informal é utilizada. O agrupamento é feito na base de mercado (a missão) e suas unidades são relativamente pequenas, possibilitando que o fluxo de decisão possa fluir de todos os níveis para todos os níveis.

As organizações missionárias tendem a ser jovens, com pouca tendência a envelhecer, com algumas exceções. Não costumam crescer muito, já que dependem de ajustamento mútuo entre seus membros, o que não impede seu desmembramento em unidades com relativa independência, mantendo em comum a ideologia original. O sistema técnico é simples ou inexistente. O ambiente não é complexo, já que de outra forma, seriam necessários especialistas habilitados que tenderiam a ter status superior aos demais, diferenciando a estrutura. O Quadro 12 sintetiza as referidas configurações e respectivos aspectos básicos. 
Quadro 12 - Síntese das dimensões das seis configurações organizacionais

\begin{tabular}{|c|c|c|c|c|c|c|}
\hline & $\begin{array}{l}\text { Estrutura } \\
\text { Simples }\end{array}$ & $\begin{array}{l}\text { Burocracia } \\
\text { Mecanizada }\end{array}$ & $\begin{array}{l}\text { Burocracia } \\
\text { Profissional }\end{array}$ & $\begin{array}{l}\text { Forma Divi- } \\
\text { sionalizada }\end{array}$ & Adhocracia & Missio-nária \\
\hline $\begin{array}{l}\text { Mecanismo- } \\
\text { chave coor- } \\
\text { denação }\end{array}$ & $\begin{array}{l}\text { Supervisão } \\
\text { direta }\end{array}$ & $\begin{array}{l}\text { Padronização } \\
\text { trabalho }\end{array}$ & $\begin{array}{c}\text { Padronização } \\
\text { habilidades }\end{array}$ & $\begin{array}{c}\text { Padronização } \\
\text { outputs }\end{array}$ & $\begin{array}{l}\text { Ajustamento } \\
\text { mútuo }\end{array}$ & $\begin{array}{c}\text { Padronização } \\
\text { normas } \\
\text { (socialização) }\end{array}$ \\
\hline $\begin{array}{l}\text { Parte-chave } \\
\text { orga-nização }\end{array}$ & $\begin{array}{c}\text { Cúpula } \\
\text { estratégica }\end{array}$ & $\begin{array}{c}\text { Tecnoestrutu- } \\
\text { ra }\end{array}$ & $\begin{array}{c}\text { Núcleo } \\
\text { operacional }\end{array}$ & $\begin{array}{c}\text { Linha } \\
\text { intermediária }\end{array}$ & $\begin{array}{l}\text { Assessoria } \\
\text { apoio }\end{array}$ & Ideologia \\
\hline $\begin{array}{l}\text { Parâmetros } \\
\text { design: Espe- } \\
\text { cialização } \\
\text { tarefas }\end{array}$ & $\begin{array}{c}\text { Pouca } \\
\text { especializa- } \\
\text { ção }\end{array}$ & $\begin{array}{c}\text { Muita } \\
\text { especializa- } \\
\text { ção horizon- } \\
\text { tal e vertical }\end{array}$ & $\begin{array}{c}\text { Muita espe- } \\
\text { cialização } \\
\text { horizontal }\end{array}$ & $\begin{array}{c}\text { Alguma } \\
\text { especialização } \\
\text { horizontal e } \\
\text { ver-tical }\end{array}$ & $\begin{array}{c}\text { Muita espe- } \\
\text { cialização } \\
\text { horizontal }\end{array}$ & $\begin{array}{c}\text { Pouca } \\
\text { especialização }\end{array}$ \\
\hline $\begin{array}{l}\text { Treinamen- } \\
\text { to e } \\
\text { doutrinação }\end{array}$ & $\begin{array}{c}\text { Pouco } \\
\text { treinamento e } \\
\text { doutrinação }\end{array}$ & $\begin{array}{c}\text { Pouco } \\
\text { treinamento e } \\
\text { doutrinação }\end{array}$ & $\begin{array}{c}\text { Muito } \\
\text { treinamento e } \\
\text { doutrinação }\end{array}$ & $\begin{array}{l}\text { Algum treina- } \\
\text { mento e doutri- } \\
\text { nação }\end{array}$ & $\begin{array}{c}\text { Muito } \\
\text { treinamento }\end{array}$ & $\begin{array}{c}\text { Muita } \\
\text { doutrinação }\end{array}$ \\
\hline $\begin{array}{l}\text { Formaliza- } \\
\text { ção compor- } \\
\text { tamento, } \\
\text { burocrático/ } \\
\text { orgânica }\end{array}$ & $\begin{array}{c}\text { Pouca } \\
\text { formalização, } \\
\text { orgânica }\end{array}$ & $\begin{array}{c}\text { Muita } \\
\text { formalização, } \\
\text { burocrática }\end{array}$ & $\begin{array}{c}\text { Pouca } \\
\text { formalização, } \\
\text { burocrática }\end{array}$ & $\begin{array}{l}\text { Muita formali- } \\
\text { zação (dentro } \\
\text { das divisões), } \\
\text { burocrática }\end{array}$ & $\begin{array}{c}\text { Pouca } \\
\text { formalização, } \\
\text { orgânica }\end{array}$ & $\begin{array}{l}\text { Pouca for- } \\
\text { malização, } \\
\text { burocrática }\end{array}$ \\
\hline $\begin{array}{l}\text { Agrupamen- } \\
\text { to }\end{array}$ & $\begin{array}{l}\text { Geralmente } \\
\text { funcional }\end{array}$ & $\begin{array}{l}\text { Geralmente } \\
\text { funcional }\end{array}$ & $\begin{array}{l}\text { Funcional e } \\
\text { por mercado }\end{array}$ & Por mercado & $\begin{array}{l}\text { Funcional e } \\
\text { por mercado }\end{array}$ & Por mercado \\
\hline $\begin{array}{l}\text { Tamanho da } \\
\text { unidade }\end{array}$ & Grande & $\begin{array}{c}\text { Grande na } \\
\text { base, peque- } \\
\text { na no restante }\end{array}$ & $\begin{array}{c}\text { Grande na } \\
\text { base, peque- } \\
\text { na no restante }\end{array}$ & $\begin{array}{l}\text { Grande (na } \\
\text { cúpula) }\end{array}$ & $\begin{array}{c}\text { Pequena em } \\
\text { toda a } \\
\text { unidade }\end{array}$ & Pequena \\
\hline $\begin{array}{l}\text { Planejamen- } \\
\text { to e sistemas } \\
\text { de controle }\end{array}$ & $\begin{array}{c}\text { Pouco } \\
\text { planejamento } \\
\text { e controle }\end{array}$ & $\begin{array}{c}\text { Planejamento } \\
\text { das ações }\end{array}$ & $\begin{array}{c}\text { Pouco } \\
\text { planejamento } \\
\text { e controle }\end{array}$ & $\begin{array}{l}\text { Muito controle } \\
\text { de desempenho }\end{array}$ & $\begin{array}{c}\text { Planejamento } \\
\text { limitado de } \\
\text { ações }\end{array}$ & $\begin{array}{l}\text { Pouco pla- } \\
\text { nejamento e } \\
\text { controle }\end{array}$ \\
\hline $\begin{array}{l}\text { Instrumentos } \\
\text { interligação }\end{array}$ & $\begin{array}{l}\text { Poucos } \\
\text { instrumentos } \\
\text { interligação }\end{array}$ & $\begin{array}{l}\text { Poucos } \\
\text { instrumentos } \\
\text { interligação }\end{array}$ & $\begin{array}{l}\text { Instrumentos } \\
\text { interligação } \\
\text { na adminis- } \\
\text { tração }\end{array}$ & $\begin{array}{c}\text { Poucos } \\
\text { instrumentos } \\
\text { interligação }\end{array}$ & $\begin{array}{c}\text { Muitos } \\
\text { instrumentos } \\
\text { interligação } \\
\text { em toda } \\
\text { organização }\end{array}$ & $\begin{array}{l}\text { Muitos ins- } \\
\text { trumentos de } \\
\text { interligação }\end{array}$ \\
\hline $\begin{array}{l}\text { Descentrali- } \\
\text { zação }\end{array}$ & Centralização & $\begin{array}{l}\text { Descentraliza } \\
\text {-ção horizon- } \\
\text { tal limitada }\end{array}$ & $\begin{array}{l}\text { Descentraliza } \\
\text { ção horizon- } \\
\text { tal e vertical }\end{array}$ & $\begin{array}{l}\text { Descentraliza- } \\
\text { ção vertical } \\
\text { limitada }\end{array}$ & $\begin{array}{l}\text { Descentraliza } \\
\text { ção seletiva }\end{array}$ & $\begin{array}{l}\text { Descentra- } \\
\text { lização pura }\end{array}$ \\
\hline $\begin{array}{l}\text { Fatores situa- } \\
\text { cionais: Ida- } \\
\text { de e tamanho }\end{array}$ & $\begin{array}{l}\text { Tipicamente } \\
\text { jovem e } \\
\text { pequena }\end{array}$ & $\begin{array}{c}\text { Tipicamente } \\
\text { antiga e } \\
\text { grande }\end{array}$ & Variadas & $\begin{array}{l}\text { Tipicamente } \\
\text { antiga e muito } \\
\text { grande }\end{array}$ & $\begin{array}{c}\text { Tipicamente } \\
\text { jovem }\end{array}$ & $\begin{array}{l}\text { Tipicamente } \\
\text { jovem e } \\
\text { pequena }\end{array}$ \\
\hline $\begin{array}{l}\text { Sistema } \\
\text { técnico }\end{array}$ & $\begin{array}{l}\text { Simples, não } \\
\text { regulado }\end{array}$ & $\begin{array}{c}\text { Regulado, } \\
\text { mas não } \\
\text { automatizado } \\
\text { nem } \\
\text { sofisticado }\end{array}$ & $\begin{array}{l}\text { Não regulado } \\
\text { ou sofisticado }\end{array}$ & $\begin{array}{c}\text { Divisível, caso } \\
\text { contrario igual } \\
\text { à Burocracia } \\
\text { Mecanizada }\end{array}$ & $\begin{array}{l}\text { Muito sofis- } \\
\text { ticado e auto- } \\
\text { matizado; ou } \\
\text { não regulado } \\
\text { ou sofisticado }\end{array}$ & $\begin{array}{l}\text { Simples e não } \\
\text { regulado }\end{array}$ \\
\hline Ambiente & $\begin{array}{c}\text { Simples e } \\
\text { dinâmico; às } \\
\text { vezes hostil }\end{array}$ & $\begin{array}{c}\text { Simples e } \\
\text { estável }\end{array}$ & $\begin{array}{c}\text { Complexo e } \\
\text { estável }\end{array}$ & $\begin{array}{l}\text { Relativamente } \\
\text { simples e está- } \\
\text { vel; mercados } \\
\text { diversificados }\end{array}$ & $\begin{array}{l}\text { Complexo e } \\
\text { dinâmico; às } \\
\text { vezes } \\
\text { diferentes }\end{array}$ & Simples \\
\hline Poder & $\begin{array}{l}\text { Controle exe- } \\
\text { cutivo princi- } \\
\text { pal; freqüen- } \\
\text { temente pro- } \\
\text { prietário; não } \\
\text { segue a moda }\end{array}$ & $\begin{array}{l}\text { Tecnocrático } \\
\text { e, às vezes, o } \\
\text { controle é } \\
\text { externo; não } \\
\text { segue a moda }\end{array}$ & $\begin{array}{l}\text { Controle dos } \\
\text { operadores } \\
\text { profissionais; } \\
\text { segue a moda }\end{array}$ & $\begin{array}{l}\text { Controle da } \\
\text { linha inter- } \\
\text { mediária; se- } \\
\text { gue a moda } \\
\text { (especialmente } \\
\text { do setor) }\end{array}$ & $\begin{array}{l}\text { Controle de } \\
\text { especialistas; } \\
\text { muito sujeita } \\
\text { à moda }\end{array}$ & $\begin{array}{c}\text { Controle da } \\
\text { ideologia. }\end{array}$ \\
\hline
\end{tabular}

Fonte: Adaptado de Mintzberg (2003, p. 310-313). 
A tipologia de Mintzberg $(2001,2003)$ pode ser considerada mais abrangente do que as anteriores por identificar um amplo conjunto de variáveis interdependentes - parâmetros de design e fatores situacionais - que influenciam a estrutura organizacional de uma organização, muitas delas, consideradas isoladamente nas demais tipologias. No entanto, é preciso considerar a seguinte afirmação de Mintzberg et al (2000, p. 227):

[...] cada configuração, da maneira pela qual está apresentada, é idealizada - uma simplificação, de fato uma caricatura da realidade. Nenhuma organização real é exatamente como qualquer uma das acima mencionadas, embora algumas cheguem bastante perto.

Portanto, as configurações organizacionais apresentam estruturas puras, difíceis de encontrar na prática. O mais comum será encontrar estruturas que se aproximam de uma dessas configurações à medida que buscam harmonizar seus parâmetros de design e seus fatores situacionais. Merece destaque a existência de estruturas híbridas, ou melhor, estruturas que apresentam características de mais de uma estrutura pura (MINTZBERG, 2003, p. 317320). Um segundo ponto destacado por Mintzberg (2003, p. 322-323) é que as configurações podem ser utilizadas para descrever transições estruturais, isto é, a mudança de um tipo de estrutura organizacional para outra. Nesse sentido, esse autor identifica dois importantes padrões relacionados aos estágios de desenvolvimento estrutural das organizações. O primeiro diz respeito às organizações que surgem em ambientes simples. Ratificando o que foi frisado sobre esse ponto, a maioria das organizações passa pela estrutura simples e, à medida que crescem, tendem a formalizar o comportamento, de forma que podem se transformar em burocracias mecanizadas. Seguindo o processo de crescimento, essas organizações tendem a se diversificar e a se transformar em formas divisionalizadas. Obviamente, outras forças podem surgir e conduzir às organizações a outras estruturas organizacionais. $O$ segundo padrão está relacionado a ambientes complexos, onde, ao invés de se transformarem em burocracias mecanizadas, as organizações tendem a se tornar adhocracias. Tais organizações, à medida que envelhecem, também tendem a se transformar em burocracias, podendo ser burocracias profissionais, quando se concentram em determinadas especialidades, ou em burocracias mecanizadas, quando se concentram em áreas mais simples. A organização missionária em muito se assemelha às estruturas simples, de forma que esse pensamento pode ser estendido a esse tipo de estrutura organizacional. Destaca-se como último ponto, dentro da abordagem da configuração das estruturas organizacionais, o fato das organizações - na busca da consistência entre parâmetros de design e fatores situacionais - poderem desenvolver novos tipos estruturais, tal como afirma Mintzberg (2003, p. 327): 
[...] essas organizações devem criar suas próprias configurações [...], construir estruturas novas, não imaginadas, embora igualmente consistentes. Assim, oferecemos uma hipótese final da eficácia organizacional que, embora compatível com as exigências das outras por congruência e consistência, as transcende. Denominamos ela de hipótese da criação: às vezes, uma estruturação eficaz requer a criação de uma nova configuração, uma combinação original, embora consistente, dos parâmetros de design e dos fatores situacionais.

Busca-se com esses conceitos identificar qual estrutura organizacional predomina entre as ONGs. Caso exista, é preciso relacioná-la com os seus indicadores de desempenho, tendo em vista que uma entidade tende a ser eficaz quando tem sua estrutura determinada pela consistência entre parâmetros de design e fatores situacionais. Outros autores utilizaram a tipologia de Mintzberg na busca de relacionamentos com variáveis diversas. Hardy \& Fachin (2000), ao investigarem o processo de formação de estratégia em universidades brasileiras, relacionaram processo de formação de estratégia com variáveis estruturais e contextuais. Nessa mesma linha, Nunes (1998) analisou a administração universitária tendo por base a tipologia das estruturas organizacionais de Mintzberg. Ressalta-se que a tipologia original de Mintzberg $(2001,2003)$ foi ampliada por outros pesquisadores, dentre os quais, Hardy \& Fachin (2000, p. 36) que apresentaram uma tipologia composta de dez arranjos organizacionais incluindo os seis apresentados por Mintzberg e outros quatro, a saber: burocracia carismática, organização política, anarquia organizada e tecnocrática. A seguir, apresentam-se alguns estudos acerca das características organizacionais das ONGs.

\subsection{Características Organizacionais de Organizações Não-Governamentais}

Coelho (2002) realizou pesquisa empírica envolvendo 74 entidades sem fins lucrativos brasileiras (13\% de ONGs) e 20 norte-americanas ( $85 \%$ de ONGs) em que compara características organizacionais dessas entidades. Uma das conclusões foi que as estruturas de funcionamento das entidades de ambos os países se assemelhavam, embora o grau de institucionalização das americanas seja maior, “[...] havendo mesmo um certo burocratismo".

$\mathrm{Na}$ análise das ONGs brasileiras, Coelho (2002, p. 116-117) detectou que o Estatuto Social - peça jurídica que garante a existência formal das entidades do Terceiro Setor - existe basicamente para cumprir exigência legal, pois estabelece quem são seus dirigentes e que obrigações esses devem cumprir. Sobre esse aspecto, Coelho constatou "[...] que os conselhos diretivos existem e funcionam, embora de forma esporádica". A forma mais comum de composição do conselho diretivo incluía uma assembléia geral, um conselho fiscal e uma diretoria executiva. A autora acrescenta que essa estrutura “[...] é mais atuante e participativa nas organizações não-governamentais e nas fundações do que nas associações”. 
As funções usualmente atribuídas à diretoria são planejamento, gestão, execução e avaliação das atividades desenvolvidas. Cabe-lhe, ademais, estabelecer contratos com instituições públicas e privadas com o objetivo de firmar parcerias. Assim, concentra-se na figura do diretor, de uma forma geral, a organização administrativa da entidade. Ele é o responsável pela administração da instituição, quem garante seu funcionamento, quem provê necessidades materiais e financeiras e organiza promoções e eventos para arrecadar recursos. Tanto o planejamento quanto a programação das atividades, além da administração de pessoal e da administração orçamentário-financeira são responsabilidades da diretoria da instituição. Em geral, unidades especializadas ou instituídas unicamente para esse fim são raramente encontradas nas ONGs, mas existe pessoal que fornece o apoio necessário para a execução dessas atividades, enquanto outras entidades recorrem à terceirização. Sob a ótica da teoria de Mintzberg pode-se afirmar que essas instituições possuem baixos níveis de tecnoestrutura e de assessoria de apoio. Tal fato é reforçado quando Coelho (2002, p. 118) constata que:

Além da diretoria, não há a rigor uma estrutura formal para os demais níveis organizacionais das instituições, que acabam funcionando porque certas pessoas se responsabilizaram por determinadas funções. Essas funções não são necessariamente determinadas a priori, mas surgem de acordo com o desenvolvimento das atividades da organização.

Diante dessas constatações percebe-se que as ONGs, em geral, apresentam uma estrutura que diferencia os dirigentes daqueles responsáveis diretamente pela prestação dos serviços, ou seja, sua estrutura, basicamente, é composta por uma cúpula estratégica e pelo núcleo operacional que surge à medida que as necessidades impõem essas atividades.

Conforme Tenório (2001, p. 59) as ONGs nem sempre descrevem a divisão de tarefas dos níveis que se encontram abaixo da diretoria, o que sugere a existência de pouca especialização horizontal das tarefas, o que, naturalmente pode conduzir à sua ampliação vertical, pois se os membros executam diversas tarefas, significa que eles têm algum conhecimento de como ocorre o processo de prestação de serviços como um todo.

Aproximadamente $47 \%$ das ONGs associadas à ABONG possuem profissionais com nível superior completo ou incompleto, sendo que, aproximadamente, $12 \%$ possuem nível de pós-graduação completo ou incompleto. Esses índices indicam que há utilização do parâmetro de treinamento, conforme dispõe Mintzberg. Quanto à doutrinação, Tenório (2001, p. 12-13) afirma que "O trabalho nas ONGs pesquisadas é motivado por um ideal compartilhado pelos membros que as compõem, principalmente sua equipe de técnicos e direção". Adicionalmente, Tenório (2001, p. 72) constatou que "A unidade da organização é garantida pelo comprometimento e pela identificação desses técnicos e coordenadores com a missão da 
ONG”, sugerindo que, em alguma medida, a socialização ou padronização das normas é utilizada como mecanismo de coordenação.

Quanto ao agrupamento em unidades, Tenório (2001, p., 68) verificou que as ONGs pesquisadas mesclam o agrupamento por função com outro critério - por mercado. Fernandes (2002, p. 67), em estudo realizado com ONGs da América Latina, comprovou que o principal instrumento no processo de inovação institucional era dado por administração de projetos.

Segundo Coelho (2002, p. 146) essas organizações trabalham com um quadro de pessoal enxuto e possuem basicamente uma cúpula estratégica e um núcleo operacional, concluindo-se que elas são formadas por esses dois níveis hierárquicos de pequenas unidades.

Tenório (2001, p. 12-13) destaca que o planejamento está sujeito às fontes de financiamento e nem sempre ocorre de maneira formalizada. Quanto ao controle de desempenho, "nenhuma sistematização dos dados para efeito de avaliação do desempenho gerencial" foi constatada. Essas evidências sugerem que o sistema de planejamento e controle dessas entidades é ainda pouco desenvolvido.

Coelho (2002, p. 118) ressalta que a maioria das entidades objeto de sua pesquisa apresenta estrutura organizacional informal, conclusão a que também chegou Tenório (2001, p. 12-13) ao constatar que informalidade caracteriza as organizações pesquisadas. Dessa forma, os instrumentos de interligação constituem parâmetros importantes para possibilitar a comunicação entre os membros de entidades dessa natureza.

Há um alto grau de participação dos membros da cúpula, dos sócios, do corpo técnico e dos coordenadores, na tomada de decisões estratégicas. Ademais, existe descentralização referente às questões operacionais, de forma que os coordenadores tinham liberdade para tomarem decisões na comunidade em que atuavam. Por outro lado, não há “[...] o mesmo grau de participação do pessoal administrativo ou mesmo do cidadão-beneficiário nas discussões estratégicas" (TENÓRIO, 2001, p. 72).

Landim (1993), em estudo pioneiro, observou que existem poucas ONGs 'grandes' e muitas 'pequenas'. Coelho (2002, p. 118) reafirma os achados anteriores informando que a maioria das entidades por ela estudadas é relativamente pequena.

Tenório (2001, p. 93) detectou que essas entidades geriam recursos escassos e dispersos que, em geral, exigiam esforços permanentes e intensos de coordenação. Dessa forma, sob o enfoque de Mintzberg, pode-se afirmar que há algum grau de dinamismo no ambiente em que atuam.

Ainda com referência aos recursos, ressalta-se que eles provêm em grande proporção de fontes externas à entidade e que vêm acompanhados de exigências. Dentre essas, destaca- 
se a prestação de contas, ou seja, há um controle externo que analisa a aplicação dos recursos que lhes são disponibilizados.

Com base nessas características organizacionais levantadas por Coelho e Tenório, percebe-se que as ONGs não apresentam parâmetros de design e fatores situacionais de uma estrutura organizacional pura. Pode-se supor, no entanto, pelos resultados obtidos, que elas apresentam características organizacionais que se aproximam de uma estrutura missionária.

Por outro lado, outras pesquisas têm demonstrado que essa realidade está se transformando. Carvalho (1999) pesquisou a gestão em ONGs de Alagoas, constatando sua profissionalização e burocratização: “A visão romântica da organização horizontal baseada na igualdade e na ausência de hierarquia e autoridade, dá lugar, progressivamente, ao paradigma moderno da competência, da produtividade e da eficiência no mundo do voluntariado e das organizações". Como conseqüência: "Este fenômeno tem originado uma maior divisão do trabalho e das tarefas, uma estrutura hierárquica mais concentrada, uso do planejamento estratégico como instrumento de gestão, e uma maior complexidade administrativa e formalização dos processos de gerência”.

Diniz \& Mattos (2002), analisando ONGs Internacionais de maior porte no Brasil, mencionam que essas entidades têm passado por sucessivos ajustes organizacionais baseados na lógica de mercado, os quais têm provocado alterações conceituais em seu caráter institucional original, cujas características são: forte orientação ideológica, orientação religiosa, idéias desenvolvimentistas, voluntariado, informalidade, independência em relação ao Estado e ao mercado, igualdade e participação democrática na gestão dos processos administrativos, e caráter reivindicativo e denunciador. Constataram que apenas $17 \%$ das entidades mantiveram inalteradas as referências originais, enquanto $23 \%$ promoveram alterações e 10\% diminuíram sua importância ou mesmo a abandonaram. Pinto (2003) realizou estudo de caso em fundações corporativas em que buscou verificar o tipo de racionalidade presente em sua prática administrativa e concluiu que existe "[...] tendência pela predominância de referências instrumentais, próprios de organizações burocráticas [...]”.

Em estudo de caso envolvendo quatro ONGs sócio-ambientais, Kruglianskas (2003) procurou investigar e compreender a influência das características organizacionais e dos processos administrativos sobre o desempenho organizacional dessas entidades. No que se refere às características organizacionais e aos processos administrativos foram consideradas quatro variáveis: planejamento e controle, organização e direção, gestão de informação e capacidade de articulação. O desempenho foi analisado considerando a realização das expectativas dos stakeholders, definidos como aqueles que tenham algum interesse direto 
sobre a ONG. Foram incluídos como stakeholders os beneficiários diretos e indiretos da organização e os financiadores. A análise foi segmentada em três vetores: imagem que os stakeholders tinham da organização, avaliação da qualidade dos serviços prestados e análise de como estavam sendo atingidas as expectativas dos clientes. Ademais, dentro da análise da influência sobre o desempenho, foram consideradas três variáveis intervenientes: tamanho, foco de atuação e origem da organização. Os resultados indicaram a aceitação da hipótese de que aquelas ONGs, que internalizaram as funções do processo gerencial, adaptando-as às suas realidades, obtiveram um desempenho eficaz no meio em que atuavam. 


\section{AVALIAÇÃO DE DESEMPENHO}

É crescente a necessidade que têm as entidades, independentemente de suas naturezas, em avaliar seus desempenhos. Moreira (1996, p. 1) lembra que "as organizações que hoje se preparam para ingressar no século XXI sofrem uma série de pressões ambientais que dificilmente seriam imaginadas há vinte anos atrás”. São essas pressões que, continua o autor, exigem das entidades agilidade na condução dos negócios e busca constante por eficácia e, por esses motivos, torna-se necessário a existência de um sistema de medidas de desempenho.

No entanto, não se pode afirmar que existam indicadores de desempenho ou metodologias de avaliação de desempenho suficientemente desenvolvidos e universalmente aceitos, o que significa dificuldades nesse campo.

Se tal fato é verdadeiro para entidades com fins lucrativos, mais ainda o é para entidades sem fins lucrativos que apenas, recentemente, perceberam a necessidade de avaliação de desempenho cujos resultados, em sua maioria, são intangíveis e de longo prazo.

A necessidade de avaliação de desempenho também está presente entre organizações do Terceiro Setor. Sendo que, como afirma Drucker (1994, p. 79), entidades sem fins lucrativos tendem a não priorizar o desempenho e os resultados, ainda que sejam "[...] muito mais importantes - e muito mais difíceis de se medir e controlar - na instituição sem fins lucrativos do que na empresa". Isto porque, enquanto em uma entidade com fins lucrativos tem-se um resultado financeiro, em que o lucro ou prejuízo são suficientes para julgar o desempenho de forma concreta, entidades sem fins lucrativos precisam planejar seu desempenho a partir da missão, “[...] sem a qual o desempenho é impossível, uma vez que ela define quais são os resultados em cada instituição” (DRUCKER, 1994, p. 80).

O presente capítulo tem por objetivo apresentar estudos que propõem indicadores de desempenho ou metodologias para avaliação de desempenho, destacando dimensões que precisam ser consideradas quando dessa avaliação. No primeiro tópico buscou-se ressaltar aspectos iniciais e apresentar suas dimensões principais, sob a ótica de Moreira (1996). Em seguida, são apresentados estudos que propõem indicadores de desempenho específicos para organizações sem fins lucrativos, em especial para ONGs.

\subsection{Avaliação de Desempenho - Aspectos Iniciais e Dimensões}

Lucena (1992, p. 16) considera que “[...] se o desempenho não for gerenciado, o negócio também não será administrado adequadamente. É impossível separar essas duas 
coordenadas". Para a autora, a avaliação de desempenho deve estar orientada "[...] para a busca da realização da Missão Empresarial, traduzida em Objetivos econômicos e sociais". Para Tenório (2001, p. 120), a avaliação de desempenho de uma organização:

[...] procura analisar como a organização e suas unidades tiram proveito dos recursos de que dispõem, como reagem às oportunidades e às ameaças do contexto e quanto dos objetivos tem sido alcançado. Através do estabelecimento de mecanismos de controle a organização pode avaliar a eficiência, a eficácia e a efetividade de suas ações.

Moreira (1996, p. 21-23), por sua vez, chama a atenção para algumas falsas idéias que existem acerca das medidas de desempenho. A primeira delas é que a medida, para ser útil, necessita ser a mais precisa possível, ou seja, há uma confusão entre 'medição' e 'precisão', sendo que a finalidade básica da medição de desempenho é permitir que a organização perceba se está caminhando na direção correta, ainda que pequenos desvios existam. A segunda falsa idéia se refere ao fato de que as medidas assustam as pessoas porque, às vezes, elas podem ser utilizadas com o fim de prejudicar alguém, quando deveriam ser vistas como instrumento de feedback. A terceira falsa idéia parte da aceitação de que desempenho pode ser resumido em apenas um indicador, quando um conjunto de indicadores seria mais adequado. Por fim, tem-se a falsa idéia de que medidas subjetivas não são confiáveis, pois existe uma confusão entre falta de objetividade e falta de confiabilidade de uma medida, quando "[...] a tecnologia de medições, associada a atitudes e percepções, está bem-desenvolvida e pode levar a medidas confiáveis e válidas".

A questão da objetividade e subjetividade dos indicadores de desempenho está, em certa medida, relacionada com a utilização de medidas de performance financeiras e nãofinanceiras, já que aquelas são consideradas mais objetivas do que essas. Sobre esse aspecto, Banker et al (2000), em estudo longitudinal aplicado a uma rede de hotéis que havia implementado um sistema de avaliação de performance baseado em medidas financeiras e não-financeiras, buscaram respostas para duas questões: 1) medidas não-financeiras são mais importantes que medidas financeiras? e 2) a adoção de um plano de incentivos que aumenta a ênfase em medidas não-financeiras para gestores-chave de uma empresa é mais importante na melhora de performance financeira e não-financeira? As medidas não-financeiras empregadas foram: probabilidade de retorno e reclamação de clientes. Os autores constataram que medidas não-financeiras de satisfação de cliente estavam significativamente associadas a performance financeira futura e continham informações não refletidas nas medidas financeiras. Ademais, verificaram que tanto as medidas financeiras quanto as não-financeiras melhoraram depois de adotado o plano de incentivos que incluiu medidas não-financeiras. 
Independente desses achados, indicadores de desempenho precisam ter qualidades que são sintetizadas por Moreira (1996, p. 25-31): 1) confiabilidade - atribuir sempre o mesmo valor ao objeto que está sendo avaliado; 2) validade - medir de fato o que se propõe a medir; 3) relevância - ser capaz de fornecer alguma informação útil ao usuário, informação essa que não está contida em outros instrumentos de medida que estão sendo utilizados ou que não sejam substituíveis por esses; e 4) consistência - apresentar um grau de equilíbrio em relação a um determinado sistema de medidas.

Para Moreira (1996, p. 32) os indicadores de desempenho apresentam seis grandes dimensões: 1) resultado da atividade e utilização de recursos, 2) qualidade, 3) tempo, 4) flexibilidade, 5) produtividade e 6) capacidade de inovação. Medidas de resultado da atividade se referem a "[...] qualquer resultado integrado das atividades produtivas da empresa" (MOREIRA, 1996, p. 35). Podem ser financeiras ou não-financeiras, como, por exemplo, vendas ou faturamento, valor adicionado, lucro, produção, fatia de mercado etc. Medidas de utilização de recursos podem ser divididas em dois grupos: medidas diretas e indiretas. Medidas diretas “[...] expressam diretamente, sem nenhuma elaboração ou cálculo, o quanto se consumiu de determinado insumo num dado intervalo de tempo", enquanto medidas indiretas "[...] não se referem explicitamente a um insumo, mas cuja análise pode revelar, de forma indireta, se um ou mais insumos estão sendo melhor ou pior utilizados" (MOREIRA, 1996, p. 40). Exemplos de medidas de utilização de recursos são: diretas medidas relacionadas com mão-de-obra, matérias-primas, estoques etc.; indiretas - nível de capacidade utilizada, rotação de estoques, disponibilidade de máquinas etc.

O segundo grande grupo se refere a medidas de qualidade. Garvin (1987) apresenta oito dimensões de qualidade:

1) Performance - refere-se às características operacionais primárias de um produto;

2) Aspecto - são [...] características que suplementam o funcionamento básico do produto;

3) Confiabilidade - reflete a probabilidade de um produto apresentar defeitos dentro de um período de tempo especificado; entre as medidas mais comuns de confiabilidade estão o tempo médio da primeira falha, o tempo médio entre falhas, e a taxa de falhas por unidade de tempo;

4) Conformidade - o nível o qual o design e as características operacionais de um produto estão de acordo com os padrões estabelecidos;

5) Durabilidade - [...] economicamente, deve ser definido como o montante de uso de um produto antes que quebre e ainda seja preferível continuar consertando;

6) Serviceability - a rapidez, a cortesia, a competência e a facilidade de reparo do produto;

7) Estética - aparência, percepção, som, gosto ou aroma - é claramente uma matéria de julgamento pessoal e uma reflexão de preferência individual; e 
8) Qualidade percebida - que a qualidade de um produto hoje é similar a de ontem, ou a similaridade de qualidade entre novos produtos e aqueles existentes ${ }^{8}$.

Giffi et al (apud Moreira, 1996, p. 46) descrevem três tipos de qualidade que “[...] identificam os três níveis de qualidade reconhecíveis hoje em dia, os quais são cumulativos, sendo que a dificuldade de obter qualidade aumenta com cada um deles". Os três tipos são:

- Qualidade de conformação - Um produto de qualidade é aquele fabricado dentro da obediência às especificações; estes produtos estão dentro dos limites aceitáveis de tolerância ou os serviços [...] estão de acordo com os padrões [...];

- Qualidade de necessidade - [...] o produto possui uma qualidade tal que satisfaz completamente as necessidades do consumidor. Os atributos percebidos do produto (ou serviço) emparelham as expectativas dos clientes e preenchem suas necessidades; e

- Qualidade de espécie - Diz respeito ao nível mais alto de qualidade; neste caso, a qualidade é tão extraordinária que excede aquilo que era esperado pelo consumidor.

Quanto às medidas de tempo, Moreira (1996, p. 65) destaca que empresas mais rápidas estão em melhores condições de usufruir lucro. A velocidade pode ser considerada em dois contextos: na entrega do produto ao cliente e no desenvolvimento de novos produtos. Um aspecto também relacionado ao tempo diz respeito à confiabilidade de entrega, ou seja, pontualidade. Como exemplos de medidas de tempo estão as seguintes: tempo de espera, atrasos, tempo de lançamento de novos produtos etc.

Medida de flexibilidade está relacionada à habilidade em responder às variações de demanda. Pode ocorrer tanto em nível de empresa quanto em nível de processos de uma empresa. São exemplos de medidas de flexibilidade: tempo médio de set-up, número total de produtos por linha, disponibilidade do serviço etc. (MOREIRA, 1996, p. 77-81).

O sétimo grupo de medidas de desempenho envolve as medidas de produtividade. Tachizawa (2002, p. 86) menciona que "[...] a atual tendência nas organizações é com a produtividade e não mais com a eficiência ou eficácia, assim consideradas isoladamente". Concluindo, afirma que "[...] tem-se a produtividade como um conceito econômico que une a visão mercadológica de eficácia com a preocupação de rendimento operacional que é a ênfase do fator eficiência”. Moreira (1991, p. 2) conceitua produtividade como “[ ...] a relação entre o

\footnotetext{
8 1) performance - refers to a product's primary operating characteristics; 2) features - are [...] those characteristics that supplement their basic functioning; 3) reability - reflects the probability of a product malfunctioning or failing within a specified time period. Among the most common measures of reliability are the mean time to first failure, the mean time between failures, and the failure rate per unit time; 4) conformance the degree to which a product's design and operating characteristics meet established standards; 5) durability [...] economically, may be defined as the amount of use one gets from a product before it breaks down and replacement is preferable to continued repair; 6) serviceability - the speedy, courtesy, competence, and ease of repair; 7) aesthetics - how a product looks, feels, sounds, tastes, or smells - is clearly a matter of personal judgement and a reflection of individual preference; 8) perceived quality - that the quality of products today is similar to the quality of products yesterday, or the quality of goods in a new product line is similar to the quality of a company's established products.
} 
que foi produzido e os insumos utilizados num certo período de tempo". Existem duas categorias de produtividade de acordo com o número de insumos considerados e sua natureza: 1) produtividade total - que inclui os insumos 'capital' e 'mão-de-obra' e 2) produtividade parcial - que envolve apenas um dos insumos usados. Dessa forma, existem dois índices de produtividade parcial: 1) produtividade de mão-de-obra e 2) produtividade de capital. Moreira (1991, p. 35) enumera sete usos potenciais das medidas de produtividade:

1. Como ferramenta gerencial - verificar os efeitos de certa estrutura organizacional;

2. Como instrumento de motivação;

3. Na previsão de necessidades futuras de mão-de-obra;

4. Como indicador de crescimento relativo de áreas ou categorias funcionais da empresa;

5. Na comparação do desempenho de unidades de uma mesma empresa, com diferentes localizações geográficas;

6. Na comparação do desempenho de uma empresa com o setor a que pertence; e

7. Como instrumento de análise das fontes de crescimento econômico.

Moreira (1991, p. 40) se refere a alguns aspectos que exigem cuidados no uso das medidas de produtividade: 1) a imprecisão, 2) as relações de causa e efeito, 3) a limitação dos índices parciais para medir eficiência, 4) a diferença entre produtividade e produção, 5) a complexidade da ligação entre produtividade e salários e 6) a demora nas melhorias das condições sociais, ainda que exista relação entre desenvolvimento econômico e produtividade.

Moreira (1996, p. 83) também destaca que a produtividade total dos fatores apresenta problemas tanto no que se refere à combinação ideal entre os fatores capital e mão-de-obra quanto no que se refere à própria medida de capital. Por esse motivo, as medidas parciais de produtividade são mais comumente utilizadas.

Por fim, o último grupo de medidas de desempenho engloba as medidas de capacidade de inovação. Conforme Evans et al (apud Moreira, 1996, p. 93), inovação envolve, por um lado, "[...] a adaptação dos produtos, processos e serviços existentes na organização às tecnologias e necessidades do consumidor em contínua mudança”, por outro, “[...] a criação de novos produtos e serviços, para preencherem demandas insatisfeitas do cliente".

Kaplan \& Norton (1992) apresentam uma sistemática para avaliar o desempenho de entidades que visa ir além das medidas financeiras tradicionais. $\mathrm{O}$ conjunto de medidas proposto por esses autores é denominado de balanced scorecard, conceituado como "[...] um conjunto de medidas que fornecem aos administradores uma visão rápida, mas compreensiva do negócio"”. O balanced scorecard permite que os administradores olhem para o negócio dentro de quatro importantes perspectivas: 1) perspectiva do cliente; 2) perspectiva interna; 3 ) perspectiva de inovação e aprendizado; e 4) perspectiva financeira.

\footnotetext{
9 “[...] a set of measures that gives top managers a fast but comprehensive view of the business".
} 


\subsection{Avaliação de Desempenho em ONGs}

Analisando as medidas de avaliação de desempenho apresentadas no tópico anterior, parece claro que estão voltadas basicamente para entidades com fins lucrativos. Por esse motivo têm surgido diversas propostas de avaliação de desempenho direcionadas para entidades sem fins lucrativos, pois, conforme Drucker (1994, p. 101), “o desempenho é o teste definitivo de qualquer instituição". Continuando, o autor ressalta que "toda instituição sem fins lucrativos existe em função do desempenho em mudar as pessoas e a sociedade".

Smith (1988) considera que organizações sem fins lucrativos necessitam utilizar medidas para avaliar e controlar a performance de suas atividades que não seja o lucro. Destaca que uma alternativa amplamente empregada para tanto é a utilização de avaliadores de performance que medem o funcionamento bem-sucedido de departamentos, programas e indivíduos. Esse autor mostra que a uniqueness (especificidade) dos serviços prestados pelas entidades sem fins lucrativos conduz a um grande número de medidas de avaliação, o que dificulta a comparação entre diferentes departamentos, dificuldade essa que aumenta quando se busca comparar a performance de diferentes tipos de entidades dessa natureza.

Dessa forma, Smith (1988) propõe uma medida de performance que supere parte dos problemas de entidades sem fins lucrativos, qual seja, a relação benefício/custo que representa um indicador ideal na medição da eficiência e eficácia. Além desse aspecto, essa medida permite comparações de performance entre entidades com atuação em diferentes atividades. Uma limitação da relação benefício/custo, conforme apresenta Smith (1988), é que esse indicador é adaptável principalmente a organizações nas quais os retornos diretos ou indiretos são recebidos e cujos custos dos programas são facilmente mensuráveis. Para calculá-lo, emprega-se a metodologia: relação benefício/custo $=$ benefícios totais $\div$ custos totais.

Blickendorfer \& Janey (1988) consideram que a demanda por maior accountability e maior performance organizacional de entidades sem fins lucrativos decorre do crescimento acentuado na quantidade dessas entidades associado ao valor que a sociedade atribui aos serviços que prestam. Os autores afirmam que, inicialmente, administradores de organizações dessa natureza adaptaram práticas gerenciais empregadas por entidades com fins lucrativos, o que ocorreu com dificuldades em função de diferenças de propósitos e metas. Blickendorfer \& Janey também são da opinião que é mais difícil mensurar o desempenho em organizações sem fins lucrativos por duas razões: 1) essas organizações tendem a ter múltiplas metas colocadas em termos amplos de serviço ao público e 2) a existência de múltiplas metas torna a 
performance organizacional global não clara e freqüentemente matéria de disputa. Blickendorfer \& Janey mencionam ainda que enquanto a mensuração dos custos (com exceção do trabalho voluntário) é fácil nessas entidades, por outro lado, os resultados são de difícil mensuração, pois não apenas os benefícios são, geralmente, intangíveis como também existe um lapso de tempo entre a prestação dos serviços e o aparecimento dos resultados.

Na visão de Blickendorfer \& Janey (1988), medidas de performance, para serem úteis na tomada de decisão, devem prover informação relativa àquelas áreas particulares ou atividades vitais para a obtenção das metas organizacionais. Com base nessa aceitação, os autores referem-se a duas amplas áreas chaves de performance propostas por Drtina (apud Blickendorfer \& Janey, 1988), a saber: “eficácia do programa de serviços, que é 'o nível em que o programa está obtendo seu propósito público pretendido', e eficiência organizacional, ou 'uso gerencial dos recursos para obter os resultados programados ${ }^{10, "}$. Essa classificação é refinada por Morrell (apud Blickendorfer \& Janey, 1988), que apresenta cinco áreas chaves:

1) resultados obtidos pela organização no encontro de sua missão,

2) eficácia no planejamento estratégico, de tempo e financeiro,

3) habilidade da organização para obter estabilidade financeira,

4) alocação e uso efetivos dos bens de capital e

5) uso e desenvolvimento dos recursos humanos ${ }^{11}$.

Galer \& Holliday (1988) destacam a importância da qualidade entre entidades sem fins lucrativos. Afirmam que se alcança a qualidade quando um produto ou serviço satisfaz as expectativas do cliente ou encontra as especificações colocadas por esse sem necessidade de re-trabalho. Sete passos são referidos para se alcançar qualidade: 1) forte comprometimento gerencial; 2) metas e objetivos devem mencionar a qualidade; 3) definição do nível exigido de qualidade - os melhores padrões de qualidade podem ser mensurados objetivamente; 4) manutenção do comprometimento; 5) exame das medidas de performance; 6) inclusão da qualidade no programa de orientação da cúpula da entidade; e 7) elogios a bons serviços. Por outro lado, Galer \& Holliday (1988) relacionam quatro armadilhas que devem ser evitadas: 1) defeito de orientação e treinamento; 2) falta de delegação; 3) falta de procedimentos; e 4) comunicação pobre.

Forbes (1998) revisou um conjunto de artigos - publicados entre 1977 e 1997 - que abordaram empiricamente a mensuração de eficácia em organizações sem fins lucrativos.

\footnotetext{
10 "service program effectiveness, which is 'the degree to which the program is achieving its intended public purpose', and organizational efficiency, or 'management's use of resources to achieve program results'.

11 1) results achieved by the organization in meeting its mission; 2) effectiveness in strategic, space, and financial planning; 3) ability the organization to achieve financial ability; 4) effective allocation and use of capital assets; 5) use and development of human resources.
} 
Nesse estudo, constatou que, apesar de existir muita variação na maneira de medir a eficácia, três abordagens se destacaram: 1) goal-attainment - eficácia se refere à extensão em que uma organização é bem-sucedida na consecução de metas; 2) system research - eficácia é definida como viabilidade ou sobrevivência; e 3) reputational approach - eficácia é entendida como o produto negociado de interações repetidas entre atores organizacionais e ambiente em que atuam. Ademais, o autor verificou que os estudos analisados podiam ser segmentados em três estágios, cada qual relacionado a um objetivo de pesquisa: 1) primeiro - buscaram meios de medir a eficácia; 2) segundo - estudaram os fenômenos organizacionais associados com eficácia, tais como: práticas de governança e estrutura organizacional; e 3) terceiro objetivaram compreender o processo de avaliação de eficácia.

Herman \& Renz (1999), baseando-se em estudos anteriores, apresentam seis teses acerca da mensuração de eficácia em organizações sem fins lucrativos: 1) é sempre matéria de comparação; 2) é multidimensional e nunca será reduzida a medidas simples; 3) está pouco claro como os membros da diretoria influenciam a eficácia organizacional; 4) são mais efetivas as entidades que usam corretas práticas gerenciais; 5) é uma construção social; e 6) apresenta limitações o uso de indicadores de resultado para medir eficácia.

Vogt (1999) escreveu uma série de três artigos que tratam da mensuração de resultados em entidades sem fins lucrativos. No primeiro, o autor considera que o impacto do crescimento das necessidades humanas juntamente com a redução de recursos fez com que as entidades sem fins lucrativos se sentissem frustradas por suas medidas de mensuração tradicionais - número de beneficiários, custo por unidade de serviço e unidades de serviços prestados. Por esse motivo, Vogt (1999a) sugere a substituição de tais medidas por uma outra capaz de responder sobre o grau de satisfação das pessoas relativo à intervenção que essas entidades exercem em suas vidas. No segundo artigo, Vogt (1999b) apresenta cinco passos que devem ser seguidos para se iniciar um sistema de mensuração de resultados: 1) aperfeiçoar a demonstração de missão; 2) desenvolver critério de admissão; 3) prover missão e critério para cada programa; 4) listar stakeholders; e 5) localizar com precisão as necessidades e desejos dos stakeholders. No terceiro artigo de sua série, Vogt (1999c) apresenta quatro tipos de resultados que podem ser medidos em entidades sem fins lucrativos:

1. Medidas de eficácia medem o nível em que a entidade satisfaz sua missão [...];

2. Medidas de eficiência avaliam quão bem os serviços minimizam os esforços, despesas e desperdícios, enquanto produz os resultados desejados;

3. Medidas de satisfação do cliente avaliam quão satisfeitos estão os clientes com os serviços e os resultados desses serviços; 
4. Medidas de processo descrevem o nível em que a organização alcança os objetivos operacionais $[\ldots]^{12}$.

Roche (2000) descreve os elementos-chave da avaliação de impacto tendo por base estudos de caso realizados com diversas ONGs. Para o autor, avaliação de impacto é "[...] $a$ análise sistemática das mudanças duradouras ou significativas - positivas ou negativas, planejadas ou não - nas vidas das pessoas e ocasionadas por determinada ação ou série de ações". Portanto, o impacto decorre dos resultados alcançados. A primeira etapa de avaliação de impacto é chamada de preparatória e, dentre outros, envolve uma clara definição da finalidade da avaliação. Em seguida, são definidos os indicadores, os níveis de avaliação, as pessoas envolvidas etc. Um ponto destacado é a consideração do contexto no qual a entidade está inserida, pois esse poderá afetar os resultados.

Stout (2001) sugere uma maneira para avaliar performance organizacional em entidades sem fins lucrativos por meio de uma medida do uso do tempo. O autor denomina sua medida de Activity-Based Time Management (ABTM), ou seja, administração do tempo baseado na atividade. São enumerados oito passos para a aplicação do ABTM: 1) identificar serviços que serão avaliados; 2) localizar com precisão atividades chaves; 3) identificar direcionadores de tempo; 4) determinar direcionadores de tempo; 5) especificar recursos de tempo; 6) alocar horas às atividades; 7) associar horas com resultados; e 8) avaliar resultados. Resumindo, Stout (2001) afirma que a aplicação do ABTM possibilitará à entidade julgar se está alocando seu tempo aos resultados mais importantes, além disso, ajudará a avaliar o tempo gasto em atividades específicas e, ainda, fornecerá uma nova perspectiva em relação ao uso de recursos, sendo uma ferramenta para maximizar o sucesso organizacional.

Tenório (2001, p. 69), considerando apenas a dimensão da eficiência organizacional, cita que um meio de medir a referida eficiência é através do exame da "[...] distribuição de recursos entre órgãos de linha e staff, bem como entre as atividades finalísticas e de suporte". Mais eficientes serão aquelas entidades que colocarem a maior parte de seus recursos financeiros, humanos e materiais em órgãos de linha e em atividades finalísticas.

Tachizawa (2002, p. 207) sugere que sejam definidos indicadores de gestão para que as atividades de ONGs possam ser monitoradas. Esses indicadores poderiam "[...] ser estruturados como uma relação entre duas variáveis, na forma de numerador e denominador,

12 1. Effectiveness Measures gauge the degree to which your organization satisfies its mission [...]; 2. Efficiency Measures evaluate how well your services minimize effort, expense, and waste while producing the desired results; 3. Consumer Satisfaction Measures assess how satisfied your consumers are with your services and the outcome of those services; 4. Process Measures describe the degree to which your organization achieves its operating objectives [...]. 
em que os atributos e valores sejam factíveis de medição". Para o autor, os indicadores deveriam considerar dois níveis de abrangência: 1) indicadores de gestão e 2) indicadores de qualidade e desempenho. Tachizawa (2002, p. 208) conceitua ambos como segue:

Os indicadores de gestão destinam-se a avaliar a organização como entidade fornecedora de produtos e prestadora de serviços a seus clientes atuais e potenciais, conforme mensuração dos parâmetros estratégicos, sobretudo em seu processo de interação com o meio ambiente externo.

[...] indicadores de qualidade e de desempenho [...], destina-se à avaliação da qualidade e de desempenho relativa a cada processo da organização e é onde se situam os indicadores de gestão ambiental e de responsabilidade social.

Indicadores de qualidade medem o grau de satisfação do cliente em relação a um serviço prestado, enquanto indicadores de desempenho ou de produtividade "[...] refletem a relação de produtos (serviços)/insumos, ou seja, buscam medir a eficiência de determinado processo ou operação em relação à utilização de um recurso ou insumo específico [...]" (TACHIZAWA, 2002, p. 209-210).

$\mathrm{O}$ autor destaca que na determinação de métricas consistentes uma entidade deveria:

a) identificar as saídas mais importantes da organização e de cada processo-chave;

b) identificar as dimensões críticas de desempenho para cada uma dessas saídas;

c) determinar métricas para cada dimensão crítica;

d) desenvolver metas ou padrões para cada métrica (TACHIZAWA, 2002, p. 211).

Um outro aspecto mencionado por Tachizawa (2002, p. 212) é referente ao que pode ser obtido por meio de métricas estabelecidas pela entidade:

a) assegurar que o desempenho na organização esteja sendo gerenciado;

b) identificar adequadamente os problemas e o ordenamento de prioridades;

c) estabelecer uma compreensão clara para os funcionários do que a organização espera dos funcionários;

d) assegurar uma base objetiva e eqüitativa para recompensas e programas de incentivos.

Por fim, Tachizawa (2002, p. 226-227) apresenta um conjunto de pontos a serem observados por um bom sistema de indicadores capaz de monitorar e avaliar os resultados:

- é coerente com a visão e com a concepção que as organizações envolvidas têm sobre os objetivos centrais e as dimensões que um projeto deve considerar e resulta da negociação transparente e não impositiva dos diferentes interesses e expectativas;

- considera particularidades do contexto e foi desenvolvido com base em bom conhecimento da realidade na qual se vai intervir;

- define indicadores que captam efeitos atribuíveis às ações, serviços e produtos gerados pelo próprio projeto;

- tem indicadores bem definidos, precisos e representativos de aspectos centrais da estratégia do projeto, sem ter pretensão de dar conta da totalidade; 
- está orientado para o aprendizado, estimulando novas reflexões e a compreensão pelos vários envolvidos sobre a complexidade dos fatores que podem determinar ou não o alcance dos objetivos;

- $\quad$ prevê e especifica os meios de verificação que serão utilizados, bem como os responsáveis pela coleta de informação, pela análise e tomada de decisões;

- combina, de modo adequado à natureza do projeto, indicadores relativos à eficiência, eficácia e efetividade;

- é simples, capaz de ser compreendido por todos, e não apenas por especialistas, sem ser simplista;

- é viável do ponto de vista operacional e financeiro;

- fornece informações relevantes e em quantidade que permite a análise e a tomada de decisão;

- aproveita as fontes confiáveis de informação existentes, poupando recursos, tempo e energia do projeto.

Bradley et al (2003) referem-se às mudanças na forma de operar do Terceiro Setor para que se torne mais produtivo: 1) reduzir custos de financiamento em decorrência de altos custos de captação; 2) distribuir recursos mais rapidamente; 3) reduzir custos operacionais de programas; 4) reduzir custos administrativos; e 5) elevar a eficácia do setor. Destacam que "enquanto a maior eficiência aumenta a cifra disponível para o investimento social, a elevação da eficácia aumenta o benefício social obtido a cada dólar gasto".

Rosa \& Costa (2003) realizaram estudo sobre a maneira como quatro organizações públicas e três do terceiro setor, da cidade de Ribeirão Preto (SP), são administradas. Dois objetivos nortearam o trabalho dessas pesquisadoras: analisar e comparar o desempenho na prestação de serviços sociais de educação infantil, tendo como parâmetros a quantidade e a diversidade dos serviços, a análise dos custos e dos indicadores de desempenho especificados. Para isso, utilizaram, dentre outros, os seguintes indicadores: número de crianças; classe social; número de serviços extra; número de crianças por funcionário; número de voluntários; despesa de manutenção por criança; despesas administrativas por criança; despesas de material educacional por criança; despesas de alimentação por criança; folha de pagamento por despesa total; receita por criança; e custo por criança.

Guimarães et al (2003) apresentam um plano de indicadores construído e testado para avaliar a capacidade de gestão em organizações sociais (OS) do Estado da Bahia. Para tanto, identificaram três dimensões - organizacional, sustentabilidade dos resultados de gestão e operacional. Em cada uma, relacionaram um conjunto de indicadores. Na organizacional, itens como: atendimento de requisitos para exercício da função gerencial; quantidade de conselheiros eleitos conforme definição legal; trabalhadores que têm conhecimento sobre a existência dos conselhos etc. $\mathrm{Na}$ operacional, os seguintes indicadores: melhoria das condições físicas, além das previstas no contrato de gestão; aquisição de equipamentos, além dos previstos pelo contrato de gestão; existência de incremento na receita e redução de 
despesas nos últimos 12 meses etc. Na dimensão da sustentabilidade, têm-se: quantidade de gestores intermediários que sabem da existência de canais institucionalizados para receber críticas e sugestões dos trabalhadores e dos usuários; quantidade de usuários que recebem orientação sobre os serviços prestados; quantidade de usuários satisfeitos com os serviços prestados pela organização etc.

Silva et al (2003) realizaram estudo de caso em que investigaram a utilização de ferramentas de medição de desempenho em uma Organização da Sociedade Civil de Interesse Público (OSCIP). Discutiram possíveis semelhanças e diferenças entre o modelo de medição atualmente utilizado pela OSCIP objeto de estudo e o modelo Balanced Scorecard e, ao final, apresentaram uma proposta de Balanced Scorecard para a referida OSCIP.

Moore (2003), por sua vez, propõe uma alternativa de Balanced Scorecard designada de Public Value Strategy - para medir desempenho em organizações sem fins lucrativos. Tal proposta considera três vértices, cada qual compreendendo aspectos específicos de uma organização: 1) missão social - missão organizacional, metas estratégicas etc.; 2) legitimidade e suporte - diversificação de financiadores, reputação, credibilidade etc.; e 3) capacidade organizacional - resultados organizacionais, produtividade, eficiência etc.

Percebem-se, na análise dos estudos supracitados, os pontos mais significativos:

- um sistema de medidas de avaliação de desempenho para ser elaborada precisa considerar a Missão da entidade;

- existe dificuldade para estabelecer medidas de desempenho para ONGs em função da natureza dos serviços que são oferecidos à comunidade;

- a maioria dos estudos realizados se colocam em um plano teórico, demonstrando a necessidade de aplicação prática das propostas de avaliação de desempenho;

- há dificuldades no estabelecimento de um conjunto de medidas de avaliação de desempenho que possa ser útil para qualquer entidade sem fins lucrativos, independentemente de sua principal área de atuação; e

- ao mesmo tempo, é crescente a cobrança, não apenas dos financiadores, mas também da comunidade, no sentido de obter informações acerca do desempenho de entidades que formam o Terceiro Setor. 


\section{METODOLOGIA}

O método de abordagem utilizado para o desenvolvimento desta pesquisa foi o hipotético-dedutivo que, como afirmam Marconi \& Lakatos (2000, p. 73), considera que "toda pesquisa tem sua origem num problema para o qual se procura uma solução, por meio de tentativas (conjecturas, hipóteses e teorias) e eliminação de erros".

As etapas do método hipotético-dedutivo são apresentadas por Bunge (apud Marconi \& Lakatos, 2000, p. 79-80), a saber: 1) a partir do reconhecimento de fatos relevantes relacionados ao objeto de estudo, buscam-se lacunas ou incoerências a fim de formular o problema a ser solucionado com base no conhecimento disponível; 2) em seguida faz-se a construção de um modelo teórico, selecionando-se os fatores pertinentes para a formulação das hipóteses centrais; 3) a terceira etapa envolve a dedução de conseqüências particulares, ou seja, a busca de suportes racionais e/ou empíricos relacionados ao objeto de estudo; 4) o teste das hipóteses vem em seguida, em que é necessário o planejamento de meios de pôr à prova as predições e no qual são realizadas as operações planejadas seguidas da coleta de dados que serão classificados, analisados e reduzidos de forma a serem interpretados; 5) partindo-se das interpretações, chega-se à última etapa que é a adição ou introdução de conclusões na teoria. Nessa etapa são feitas comparações entre conclusões e conseqüências particulares destacadas na terceira etapa, de forma a se precisar o grau em que o modelo teórico pode ser confirmado ou não. Se houver necessidade, esse modelo será corrigido e, em seguida, serão apresentadas sugestões para trabalhos posteriores.

O método de procedimento utilizado foi o empírico-analítico que, conforme Martins (2002a, p. 33), privilegia estudos práticos, tendo forte preocupação com a relação causal entre variáveis, nesse caso, ‘estruturas organizacionais' e 'indicadores de desempenho' das ONGs.

As técnicas de coleta de dados são divididas por Marconi \& Lakatos (1985, p. 196) em observação direta intensiva e observação direta extensiva. Como técnica de observação direta intensiva, foi aplicado um roteiro de entrevista que, conforme Goode \& Hatt (1972, p. 172), refere-se a uma "[...] lista de pontos ou tópicos que um entrevistador deve seguir durante a entrevista".

Essa técnica de coleta de dados, caracterizada também como pesquisa de campo, foi escolhida por ser, conforme Blau \& Scott (1970, p. 33-34), “[...] o plano de pesquisa tipicamente empregado no estudo das organizações formais". Esses autores ressaltam que a pesquisa de campo permite o desenho de um quadro geral da organização, além de informações a respeito da interdependência de suas partes constituintes. Assim, para a coleta 
de dados foram realizadas entrevistas pessoais com representantes de ONGs que tivessem conhecimento da estrutura organizacional da entidade, através de um roteiro estruturado de entrevista. Dessa forma, a técnica de pesquisa adotada para essa coleta pode ser caracterizada como entrevista estruturada. A justificativa para a utilização desse instrumento decorreu da especificidade das questões, levando-se em consideração que os entrevistados poderiam não compreender o significado dos termos relacionados às características organizacionais, o que poderia levar a um entendimento não homogêneo.

A população objeto de estudo é representada pelas ONGs do Estado de São Paulo associadas à Associação Brasileira de Organizações Não-Governamentais (ABONG), entidade criada em 1991 com a responsabilidade - como consta na sua Carta de Princípios de "[...] representar coletivamente as ONGs junto ao Estado e aos demais atores da sociedade civil". Para se associar à ABONG, a entidade deve ser aceita pelo Conselho Diretor daquela associação, ter no mínimo dois anos de existência, ser autônoma e pluralista, além de ter compromisso tanto com a construção de uma sociedade democrática e participativa, quanto com o fortalecimento dos movimentos sociais de caráter democrático. Tais características conferem homogeneidade às organizações vinculadas à ABONG. No início desta pesquisa, havia, no Estado de São Paulo, 49 ONGs associadas ${ }^{13}$, sendo que 43 tinham domicílio na capital. A escolha das ONGs desse estado justifica-se por sua representatividade no quadro dessas entidades existentes no Brasil.

Buscou-se a obtenção de dados de todas as entidades, ou seja, o censo. Stevenson (1981, p. 161) menciona que há situações nas quais é mais vantajosa a utilização do censo:

- A população pode ser tão pequena que o custo e o tempo de um censo sejam pouco maiores que para uma amostra [...];

- Se o tamanho da amostra é grande em relação ao da população, o esforço adicional requerido por um censo pode ser pequeno [...];

- Se se exige precisão completa, então o censo é o único método aceitável [...];

- Ocasionalmente, já se dispõe de informação completa, de modo que não há necessidade de amostra.

A opção pela realização do censo decorreu tanto do interesse em se obter precisão completa, quanto das pequenas diferenças de custo e de tempo no caso de utilização de uma amostra em substituição à população.

\footnotetext{
${ }^{13}$ Essa quantidade se refere à data de início da pesquisa de campo - 14/11/2003.
} 


\subsection{Apresentação do Roteiro de Entrevista e Pré-Teste}

Esse tópico apresenta o roteiro de entrevista cujos itens foram definidos depois de realizados o primeiro grupo de entrevistas e a sessão de pré-teste. Essa sessão visa aperfeiçoar o instrumento de coleta de dados, revisando e direcionando aspectos da investigação. $\mathrm{Na}$ opinião de Richardson (1999, p. 202) o pré-teste "Refere-se à aplicação prévia do questionário a um grupo que apresente as mesmas características da população incluída na pesquisa”. São sugeridos cinco pontos que caracterizam sua realização: 1) deve ser entendido como um teste do processo de coleta e tratamento dos dados; 2) serve para treinar e analisar problemas apresentados pelos entrevistadores; 3) é um importante meio para se obter informações sobre o assunto estudado; 4) é um excelente momento para analisar o comportamento das variáveis, estando-se seguro de que tais elementos variem; e 5) é um momento oportuno para analisar as categorias 'outros' e 'não sabe' (RICHARDSON, 1999, p. 202-204)

Para Marconi \& Lakatos (1985, p. 202) o pré-teste pode evidenciar:

- ambigüidade das questões;

- existência de perguntas supérfluas;

- adequação ou não da ordem de apresentação das questões;

- presença de muitas questões e necessidade de serem ou não complementadas.

O pré-teste foi realizado no dia 30 de outubro de 2003 com Marco Milane, conselheiro fiscal voluntário da entidade sem fins lucrativos 'Casa Transitória Fabiano de Cristo'. Essa organização foi fundada em 1960 e tem por mantenedora a Federação Espírita, representando, assim, entidade de natureza similar àquelas que integram o objeto desse estudo, no entanto, não faz parte do universo de pesquisa, de forma que suas informações não foram incluídas para a análise e interpretação dos dados. Feitas as alterações decorrentes do pré-teste, esse instrumento de coleta de dados foi aplicado a 16 entidades que faziam parte do universo de pesquisa, entre os dias 14 de novembro e 12 de dezembro de 2003. Em decorrência dessa aplicação, outras alterações foram realizadas no roteiro de entrevista e as informações obtidas foram aproveitadas para análises e interpretações.

O roteiro de entrevista foi dividido em quatro blocos, cuja cópia encontra-se no Apêndice A. A seguir são apresentados os quatro blocos em sua versão definitiva. 


\subsubsection{Bloco I do Roteiro de Entrevista}

As informações registradas neste Bloco I - dividido em nove itens - procuram traçar um perfil da entidade e do respondente ${ }^{14}$.

O item 1 identifica a entidade pesquisada; o item 2 registra a data de fundação da entidade, dado útil no registro da 'idade' de cada $\mathrm{ONG}$ - fator situacional enumerado por Mintzberg $(2001,2003)$ - e que, além disso, foi relacionado com os tipos organizacionais; o item 3 identifica a missão da entidade, informação que permitiu agrupar ONGs que se assemelhem ou se aproximem em sua missão para, em seguida, analisar se possuem estruturas organizacionais semelhantes ou próximas; o item 4 registra a constituição jurídica da entidade - associação, fundação ou sociedade civil; o item 5 apresenta o nome do respondente; o item 6 relaciona as informações sobre o cargo ou função ocupada pelo respondente; o item 7 informa o tempo de ocupação do cargo ou função pelo respondente - essa informação permitiu, juntamente com o item 6 , analisar seus conhecimentos acerca da entidade, sobretudo aqueles referentes às características organizacionais e às relações com o ambiente, considerando que as pessoas contratadas há pouco tempo possam ter uma visão limitada da entidade quanto às informações desejadas; o item 8 identifica a idade do respondente; e o item 9 apresenta sua formação acadêmica.

\subsubsection{Bloco II do Roteiro de Entrevista}

O Bloco II - dividido em seis itens - capta informações qualitativas e quantitativas adequadas ao cálculo de indicadores de desempenho das ONGs pesquisadas. Neste bloco foram ainda incluídas informações relacionadas aos fatores situacionais, aqui registradas por questões de simplificação.

O item 1 identifica os principais fatores com os quais a entidade está comprometida ao buscar satisfazer os beneficiários através da qualidade dos serviços prestados. Para tanto, listaram-se cinco subitens e um sexto com a opção 'outras', na qual o respondente teve a liberdade de indicar um outro fator não contemplado nas demais opções e que estivesse mais bem relacionado à realidade da entidade pesquisada. É preciso ressaltar que um dos fatores atender um maior número de beneficiários com o mesmo volume de recursos - não pode ser considerado como um fator de qualidade. Constata-se a limitação deste item quando são

\footnotetext{
${ }^{14}$ As informações solicitadas no Bloco I do roteiro de entrevista são apresentadas no Apêndice B, onde consta a lista de todas as ONGs respondentes da pesquisa.
} 
consideradas aquelas entidades que não prestam serviços diretamente à comunidade ou nem mesmo têm a possibilidade de identificar quais são seus beneficiários, pois atendem um público amplo - ex. ONGs ambientalistas.

O item 2 examina o número de beneficiários diretos atendidos durante o ano de 2002, dado que - com alguma limitação - permitiu o cálculo das produtividades parciais utilizadas como indicadores de desempenho da entidade. A mais importante das limitações aponta para as entidades que não são capazes de identificar seus beneficiários diretos, seja porque a entidade não mantém um controle dos beneficiários atendidos, seja porque tem uma atuação que beneficia um público muito amplo, o que dificulta sua mensuração. É preciso deixar claro - ratificando a indicação dada no pré-teste - que os beneficiários diretos são aqueles relacionados à atividade-fim da entidade.

O item 3 identifica a quantidade de colaboradores da entidade por vínculos de trabalho e localização na estrutura organizacional. Considerando-se a realidade das ONGs em termos de divisão organizacional, esses colaboradores foram alocados nas partes que formam uma entidade tal como propõe Mintzberg. Dessa informação utilizou-se apenas o critério quantidade para determinar o fator situacional ‘tamanho' da ONG (grande, pequena ou média) que, além disso, foi relacionado com os tipos organizacionais. A informação relativa à localização dos colaboradores, por sua vez, é útil por permitir a determinação do tamanho das unidades que representa um dos parâmetros de design. Por fim, a quantidade de colaboradores foi utilizada para cálculo das produtividades parciais. Depois da realização do pré-teste, ficou determinado que fossem incluídos, na quantidade de colaboradores, apenas os voluntários cuja colaboração fosse regular.

O item 4 examina a despesa da entidade em 2002. Três subitens compuseram esse item, quais sejam: 1) despesa total, 2) despesa administrativa (incluindo pessoal administrativo) e 3) despesa na prestação de serviços e de pessoal. As informações coletadas permitiram calcular um índice de utilização dos recursos na atividade fim, assim como, um outro referente à utilização de recursos para a manutenção física e de pessoal da entidade. Ademais, serviu de base para o cálculo da produtividade de capital.

O item 5 registra as receitas da entidade em 2002, decomposto em seis subitens, cada qual se referindo a uma possível fonte de receitas. Essa informação foi utilizada para o cálculo das produtividades parciais e também no relacionamento entre composição das fontes de receita e tipos organizacionais.

$\mathrm{O}$ item 6 lista quatro indicadores de desempenho para que a entidade indique aqueles utilizados na análise de performance. Esses indicadores são: relatórios descritivos destacando 
as atividades desenvolvidas, quantidade de beneficiários, análise financeira e quantidade de projetos desenvolvidos. Neste item foi incluída ainda a opção 'outras' para possibilitar à entidade descrever os indicadores específicos às suas atividades.

\subsubsection{Bloco III do Roteiro de Entrevista}

O Bloco III - dividido em quatro itens - identifica os parâmetros de design predominantes nas estruturas organizacionais das ONGs. O item 1 identifica o tipo de agrupamento - funcional, por projetos ou matricial - pelo qual a entidade pode ser caracterizada. Essa informação relaciona-se ao parâmetro 'agrupamento em unidades'.

O item 2 subdividi-se em sete subitens com três alternativas para cada um visando identificar com que intensidade - muito, medianamente ou pouco - cada parâmetro ocorre, sempre de forma predominante, na entidade. Há entre esses subitens as seguintes relações: os subitens 1 e 2 estão relacionados ao parâmetro 'especialização da tarefa'; o subitem 3 está relacionado ao parâmetro ‘formalização do comportamento'; os subitens 4 e 5 são relativos ao parâmetro 'treinamento e doutrinação'; e os subitens 6 e 7 formam o parâmetro 'sistemas de planejamento e controle'.

$\mathrm{O}$ item 3 identifica a intensidade na qual o parâmetro de design 'instrumentos de interligação' é utilizado, ou seja, se são muito, medianamente ou pouco utilizados.

Por fim, tem-se, no Bloco III, o item 4 que trata da distribuição de poder dentro da entidade, ou seja, quem pode tomar decisões. Para tanto, solicitou-se que o respondente indicasse quais componentes da estrutura organizacional participavam do processo de tomada de decisão. Esses componentes, em um momento posterior, foram agrupados nas partes da entidade identificadas por Mintzberg (2001, 2003). Relaciona-se este item aos dois últimos parâmetros de design: 'descentralização vertical' e 'descentralização horizontal'.

\subsubsection{Bloco IV do Roteiro de Entrevista}

O Bloco IV - dividido em cinco itens - é o último do roteiro de entrevista. Nele caracteriza-se os demais fatores situacionais que interferem sobre a entidade, com exceção do item 5 que representou um espaço no qual o respondente poderia acrescentar comentários, de natureza diversa, acerca da pesquisa.

O item 1 examina as quatro dimensões do ambiente em que a entidade atua. Para cada

dimensão são apresentadas escalas de atitudes de 1 a 5 , sendo que 1 e 2 representam a 
proximidade maior em uma extremidade, 4 e 5 a proximidade maior na extremidade oposta e 3 um ponto neutro. $\mathrm{O}$ respondente tem que indicar qual escala em cada dimensão melhor representa a realidade da ONG. Esse item relaciona-se ao fator situacional 'ambiente'.

O item 2 identifica se a entidade possui títulos públicos. A posse de tais títulos gera exigências que podem causar impacto nas estruturas organizacionais das ONGs, ou seja, representam uma espécie de controle externo que é uma dimensão do fator 'poder'.

O item 3 analisa a existência de outras formas de controle externo sobre a entidade, enumerando-se sete 'atores' que poderiam exercer esse controle e ainda a opção ‘outros'. Para cada 'ator', solicitou-se identificar a intensidade - sempre, ocasionalmente ou nunca - com que o controle é exercido, informação que também está relacionada à dimensão do controle externo do fator situacional 'poder'.

Por fim, tem-se o item 4 em que se lista seis fatores que podem determinar a estrutura organizacional da entidade, solicitando-se a indicação do preponderante. Dentre os fatores, três estão relacionados ao fator situacional 'poder', um ao fator situacional 'ambiente', um à consistência entre aspectos internos e fatores situacionais e, por fim, um outro que caracteriza uma estrutura organizacional missionária - cultura predominante no ambiente interno.

\subsection{Procedimentos para Análise da Eficácia em ONGs}

Uma entidade, quando adota uma estrutura determinada pela consistência entre parâmetros de design e fatores situacionais, tende a ser eficaz na concretização de suas metas. O conceito de eficácia é bastante difundido na literatura que trata de organizações. Para Forbes (1998) esse conceito é ao mesmo tempo poderoso e problemático: poderoso, na medida que representa uma ferramenta útil para avaliar e realçar criticamente o trabalho das organizações; problemático, no sentido de poder significar coisas diferentes para diferentes pessoas. Gibson et al (1988, p. 77) sentenciam que, do ponto de vista da sociedade, a eficácia "[...] é o grau segundo o qual as organizações atingem suas missões, metas e objetivos dentro das restrições de recursos limitados”. Esse conceito envolve duas dimensões: uma é a realização dos objetivos e outra a escassez de recursos. Dentro desse contexto, surge o conceito de eficiência referente à maximização dos fins com o menor volume de recursos. Vogt (1999a) afirma que medidas de eficácia mensuram o nível com o qual uma organização satisfaz sua missão. Para Smith (1998), medidas de eficácia devem determinar quão bem um serviço é prestado ou quão bem-sucedido um departamento ou programa está indo ao encontro dos objetivos previamente estabelecidos. 
Indicadores de desempenho foram utilizados como proxy para medir a eficácia das ONGs. Moreira (1996, p. 1) afirma que o conceito de desempenho está relacionado com a "[...] agilidade na consecução dos negócios, bem como a busca constante de eficácia". Negócio aqui deve ser entendido em um sentido amplo, incluindo não apenas aqueles que envolvem finalidades lucrativas, mas também os que não têm essa finalidade, caso das ONGs. A escolha de mais de um indicador visa superar a falsa idéia, descrita por Moreira (2001, p. 21-23), de que apenas um indicador seja suficiente para medir desempenho.

Foram utilizados os seguintes indicadores de desempenho que buscam avaliar duas de suas dimensões: quantitativos - medidas de produtividade e índices de aplicação dos recursos; qualitativos - análise do comprometimento com a qualidade. Produtividade, como Moreira (1996, p. 40) apresenta, é "definida como a relação entre a quantidade produzida e as quantidades de um ou mais insumos utilizados", sendo, portanto, uma medida de utilização de recursos. Para medir a produtividade das ONGs, isto é, medir como seus recursos estão sendo utilizados na efetivação de seus objetivos sociais, foram utilizados dois índices parciais de produtividade: 1) índice de produtividade do capital - medido pelo quociente entre receita total e despesa total; e 2) índice de produtividade de mão-de-obra - medido pelo quociente entre receita total e quantidade de colaboradores. Vale ressaltar que no cálculo da produtividade de mão-de-obra considerou-se, em um primeiro momento, todos os colaboradores e, em um segundo momento, todos os colaboradores com exceção dos voluntários. Ademais, utilizou-se também o número de beneficiários diretos - como medida de resultado - em substituição ao valor da receita total.

A escolha de índices parciais em lugar de um índice total de produtividade decorre de este último apresentar problemas maiores, tanto no que se refere à forma de combinar os insumos capital e trabalho, decorrente da dificuldade em se atribuir peso a cada um dos insumos, quanto à própria medida de capital.

Os índices de aplicação de recursos também estão divididos em duas dimensões complementares: 1) índice de aplicação dos recursos na atividade fim, medido pelo quociente entre despesa gasta diretamente na prestação dos serviços mais despesa de pessoal e despesa total; 2) índice de aplicação dos recursos na atividade meio, medido pelo quociente entre despesa administrativa (incluindo pessoal administrativo) e despesa total.

Os índices de aplicação dos recursos são indicados por Tenório (2001, p. 69) como um meio de medir a eficiência organizacional de entidades sem fins lucrativos, sendo mais eficientes aquelas que consumirem a maior parte dos recursos em atividades finalísticas. A relação benefícios totais $\div$ custos totais, por sua vez, é defendida por Smith (1998) como um 
indicador ideal na medição da eficiência e eficácia. Essa relação é semelhante ao cálculo da produtividade total que, em função das dificuldades mencionadas, foi preterida pelas medidas de produtividade parcial.

Quanto ao índice de qualidade, questionou-se o seguinte papel das ONGs: se elas estão comprometidas na busca da satisfação dos beneficiários através da qualidade na prestação dos serviços e, caso estejam, quais itens indicam tal comprometimento e, se de fato esses itens podem ser indicativos de que a entidade está realmente comprometida com a qualidade.

\subsection{Plano de Análise e Interpretação dos Resultados}

A análise e interpretação dos dados, segundo Martins (2002a, p. 55), representa a fase em que "[...] o investigador irá classificar os dados, dando-lhes ordem ou colocando-os nas diversas categorias, segundo critérios que facilitem a análise e interpretação em face dos objetivos da pesquisa”. Para tanto, podem ser utilizadas tabelas, gráficos, dentre outras representações visuais que descrevam o comportamento das variáveis.

Utilizou-se para a análise e interpretação dos dados tanto a análise descritiva quanto a análise quantitativa. A análise descritiva, nas palavras de Ferrari (1982, p. 240), tem por finalidade "[...] enumerar ou descrever as características dos fenômenos (coisas, objetos, conhecimentos ou eventos) [...]”. A análise quantitativa, por sua vez, está relacionada ao tratamento estatístico dos dados coletados na pesquisa de campo. As técnicas de análise quantitativa utilizadas foram a construção de distribuições de freqüências, o cálculo da freqüência relativa ponderada e a análise da aderência conceitual. Essa última significa o grau em que a organização apresenta parâmetros de design e fatores situacionais de uma configuração de estrutura organizacional pura, como apresentada por Mintzberg (2001, 2003).

Também representando uma técnica de análise quantitativa, o teste $\chi^{2}$ (qui-quadrado) técnica não-paramétrica - foi empregado na comparação dos resultados obtidos pela pesquisa empírica com as proposições esperadas e teoricamente enunciadas para se explicitar - ou não - a associação entre variáveis. Hair et al (1998, p. 549-550) afirmam que existem três passos para o cálculo do valor $\chi^{2}$ (qui-quadrado): 1) cálculo das freqüências esperadas, 2) cálculo da diferença entre as freqüências esperadas e as freqüências observadas e 3) cálculo do valor $\chi^{2}$ (qui-quadrado). Martins (2002b, p. 256-257) apresenta o procedimento para que esse teste seja realizado: 1) enunciar as hipóteses $\mathrm{H}_{0}$ e $\mathrm{H}_{1}$, onde $\mathrm{H}_{0}$ afirmará não haver discrepância entre as freqüências observadas e as esperadas e $\mathrm{H}_{1}$ afirmará haver discrepância; 2) fixar o nível de significância $(\alpha)$ e escolher a variável qui-quadrado com $\varphi=(K-1)$, sendo $K o$ 
número de eventos; 3) determinar as regiões de aceitação e rejeição; 4) calcular a variável por meio da fórmula $\chi^{2}=\sum_{i=1}^{k} \frac{\left(F_{o i}-F_{e i}\right)^{2}}{F_{e i}}$; e 5) conclusão - se o valor calculado for inferior ao valor crítico, não se rejeita $\mathrm{H}_{0}$, de outra forma, se for superior ao valor crítico, rejeita-se $\mathrm{H}_{0}$.

Por fim, foi aplicado o teste Kruskal-Wallis - técnica de análise quantitativa nãoparamétrica - que, conforme Martins (2002b, p. 280), “Trata-se de teste extremamente útil para decidir se $\mathrm{K}$ amostras $(\mathrm{K}>2)$ independentes provêm de populações com médias iguais". Foi utilizada a ferramenta 'Analyze - Nonparametric Tests - K Independent Samples' do programa estatístico SPSS, versão 10.0, para o cálculo desse teste.

\subsection{Limitações da Pesquisa}

Há, nesta pesquisa, algumas limitações que são enumeradas a seguir. A primeira refere-se ao instrumento de coleta de dados. Richardson (1999, p. 205) destaca algumas limitações decorrentes da utilização do roteiro de entrevista estruturado, ou como designa o autor, questionário por contato direto:

1. Muitas vezes não se obtém os $100 \%$ de respostas [...], podendo-se produzir vieses importantes na amostra, que afetam a representatividade dos resultados. [...].

2. Problema de validade. Nem sempre é possível ter certeza de que a informação proporcionada pelos entrevistados corresponde à realidade. [...].

3. Problema de confiabilidade. As respostas dos indivíduos variam em diferentes períodos de tempo.

Assim, de forma resumida, pode-se afirmar que uma importante limitação relativa à utilização do roteiro de entrevista estruturado como instrumento de coleta de dados decorre da má interpretação dos itens apresentados. Essas limitações são, em parte, superadas pela presença do pesquisador durante as entrevistas.

Uma segunda limitação resulta da utilização de índices de produtividade para mensuração do desempenho. Moreira (1991, p. 6-7) faz duas observações quanto à utilização desses índices: 1) no que se refere ao período base ao qual são referidos, corre-se o risco de se obter dados de um período atípico, de forma que poderia ser mais representativo um estudo longitudinal; 2) e é possível que um mesmo índice de produtividade, por exemplo, a produtividade de mão-de-obra, seja calculada de muitas formas possíveis, o que nem sempre conduzirá aos mesmos resultados, ou seja, tanto pode ser utilizado o número de colaboradores quanto a quantidade de horas trabalhadas para cálculo desse índice, não se podendo afirmar que os resultados apresentarão tendências iguais. 
Ainda relacionado aos índices de produtividade, registra-se uma terceira limitação relacionada à utilização do valor da receita total como medida de resultado. Tal fato sugere a existência de uma relação positiva de dependência entre o resultado alcançado pelas ONGs e a quantidade de recursos obtidos. A aceitação dessa relação fica comprometida quando são considerados os achados de Frumkin \& Kim (2000) que, pesquisando 2.359 organizações sem fins lucrativos ao longo de 11 anos, constataram que a eficiência organizacional não aparece como um fator determinante do nível de contribuições recebidas.

Uma quarta limitação se refere à falta de consistência quanto aos valores classificados como despesa administrativa, despesa com projetos e despesa com pessoal. Tal fato compromete a comparação entre as ONGs pesquisadas.

Em geral, a utilização de indicadores de resultados para medir eficácia em organizações sem fins lucrativos, conforme Herman \& Renz (1999), são limitados e podem ser perigosos. Ademais, a Missão das entidades não foi considerada na definição dos indicadores utilizados nesta pesquisa, fato que poderia levar a uma maior diversidade de medidas de desempenho, dificultando a comparabilidade. Dessa forma, os indicadores de desempenho aplicados neste estudo devem ser considerados mais como um esforço de se analisar o desempenho dessas entidades, entre tantos outros possíveis. Análises de desempenho para entidades sem fins lucrativos exigem métricas próprias que possam também considerar resultados que são intangíveis.

Por fim, é preciso lembrar que os resultados desta pesquisa estão limitados ao universo pesquisado, não sendo possível realizar qualquer generalização, seja em relação às demais ONGs associadas à $\mathrm{ABONG}$, seja em relação ao universo do Terceiro Setor. 


\section{ANÁLISE DOS RESULTADOS}

A análise dos resultados apresenta as informações obtidas por meio de 34 entrevistas realizadas - 32 no Município de São Paulo e duas em Campinas - no período de 14 de novembro de 2003 a 16 de junho de 2004.

Vale ressaltar que, no início desta pesquisa, havia 49 ONGs associadas à ABONG no Estado de São Paulo. Foram observados problemas com seis dessas ONGs: duas não foram encontradas - porque descontinuaram suas atividades ou mudaram de endereço e tal mudança não foi comunicada à $\mathrm{ABONG}$; duas achavam-se em processo de descontinuidade; uma não fazia mais parte do cadastro dessa associação; e a última não representava uma entidade constituída juridicamente, pois fazia parte de outra entidade não associada à ABONG. Assim, das 43 entidades contatadas, não foi possível a realização de entrevistas com nove ONGs $(18,37 \%)$. Este trabalho cobriu, portanto, $69,39 \%$ da população a que se visava atingir.

A análise divide-se em quatro partes. Inicialmente, apresenta-se a identificação das estruturas organizacionais predominantes, dentro da tipologia proposta por Mintzberg (2001, 2003). Em seguida, analisam-se as relações entre tipos organizacionais e atividade principal, idade, tamanho e composição das receitas. Na terceira parte, são analisados os indicadores de desempenho. Por fim, faz-se a análise acerca da relação entre tipos organizacionais e indicadores de desempenho dessas entidades.

\subsection{Identificação e Análise da Estrutura Organizacional Predominante}

O passo inicial para a identificação da estrutura organizacional predominante cabe à análise da intensidade de cada parâmetro de design e fator situacional. O primeiro grupo considerado abrange os seguintes parâmetros de design: especialização das tarefas (horizontal e vertical), formalização do comportamento, treinamento e doutrinação, sistemas de planejamento e controle e instrumentos de interligação. As intensidades - 'muito', 'medianamente' e 'pouco' - foram as apresentadas para tais parâmetros, cabendo a cada ONG escolher uma delas para cada parâmetro.

A Tabela 9 apresenta os dados coletados. 
Tabela 9 - Distribuição de frequiência absoluta de parâmetros de design

\begin{tabular}{|l|c|c|c|c|c|c|}
\hline Parâmetros de design & Muito & \% & Medianamente & \% & Pouco & \% \\
\hline Especialização Horizontal das Tarefas & 7 & 20,59 & 19 & 55,88 & 8 & 23,53 \\
\hline Especialização Vertical das Tarefas & 3 & 8,82 & 5 & 14,71 & 26 & 76,47 \\
\hline Formalização do Comportamento & 12 & 35,29 & 12 & 35,29 & 10 & 29,42 \\
\hline Treinamento & 21 & 61,76 & 12 & 35,29 & 1 & 2,95 \\
\hline Doutrinação & 21 & 61,76 & 10 & 29,42 & 3 & 8,82 \\
\hline Planejamento das Ações & 19 & 55,89 & 12 & 35,29 & 3 & 8,82 \\
\hline Controle de Desempenho & 16 & 47,06 & 13 & 38,23 & 5 & 14,71 \\
\hline Instrumentos de Interligação & 24 & 70,58 & 10 & 29,42 & 0 & 0 \\
\hline
\end{tabular}

Calculou-se a freqüência relativa ponderada para cada um desses parâmetros, considerando-se, para tanto, a intensidade 'muito' como a categoria máxima de apresentação do evento e sua unidade de apresentação ' 1 '. Essas informações resultaram na seguinte codificação: muito $=1$, medianamente $=0$ e pouco $=-1$.

$$
\begin{aligned}
& \text { EspecHorizTarefas }=\frac{1 \times 20,59+0 \times 55,88+(-1) \times 23,53}{100}=-0,0294 \\
& \text { EspecVertTarefas }=\frac{1 \times 8,82+0 \times 14,71+(-1) \times 76,47}{100}=-0,6765 \\
& \text { FormalizComportamento }=\frac{1 \times 35,29+0 \times 35,29+(-1) \times 29,42}{100}=0,0587 \\
& \text { Treinamento }=\frac{1 \times 61,76+0 \times 35,29+(-1) \times 2,95}{100}=0,5881 \\
& \text { Doutrinação }=\frac{1 \times 61,76+0 \times 29,42+(-1) \times 8,82}{100}=0,5294 \\
& \text { PjanejAções }=\frac{1 \times 55,89+0 \times 35,29+(-1) \times 8,82}{100}=0,4707 \\
& \text { ControlDesempenho }=\frac{1 \times 47,06+0 \times 38,23+(-1) \times 14,71}{100}=0,3235 \\
& \text { InstrInterligação }=\frac{1 \times 70,58+0 \times 29,42+(-1) \times 0}{100}=0,7058
\end{aligned}
$$

Os quatro parâmetros que se apresentam com maior intensidade são, em ordem crescente, planejamento das ações, doutrinação, treinamento e instrumentos de interligação. A presença de planejamento das ações demonstra que existe especificação de grande parte dos resultados esperados - em termos de quantidade, qualidade, custo ou outras características 
específicas. A ocorrência de doutrinação designa a presença de processos de socialização dos membros recém-admitidos para os quais são transmitidos os valores predominantes da entidade. A existência de treinamento revela que os colaboradores, antes de admitidos nas entidades, passam por processos de aprendizagem das habilidades e conhecimentos relacionados às atividades que desenvolvem. Por fim, a expressiva utilização de instrumentos de interligação evidencia integração entre os diversos membros da entidade no sentido de existir uma cooperação no desenvolvimento das diversas atividades.

Por outro lado, o parâmetro especialização vertical das tarefas é o que ocorre com menor intensidade, sugerindo que os membros possuem compreensão do funcionamento da entidade como um todo, ou seja, sabem não apenas a importância das atividades que desenvolvem como compreendem o inter-relacionamento entre todas as atividades.

Os parâmetros especialização horizontal das tarefas e formalização do comportamento apresentam-se com intensidade mediana. Tal fato evidencia ausência de definição rigorosa das atividades que cada membro tem que desenvolver ou, em outras palavras, cada membro pode desenvolver tanto um pequeno conjunto de atividades quanto alternar para um grande número de atividades. Além disso, mostra ausência de predeterminação rigorosa do comportamento dos membros das ONGs na execução de suas atividades. Por fim, o parâmetro controle de desempenho apresenta intensidade com propensão para muito, evidenciando que essas entidades não monitoram e nem avaliam completamente seus resultados.

Para o parâmetro agrupamento em unidades foram fornecidas aos respondentes três bases de agrupamento (funcional, por mercado e matricial) para que escolhessem a predominante. O agrupamento matricial foi entendido como a utilização simultânea das duas outras bases de agrupamento.

A Tabela 10 apresenta as freqüências observadas e esperadas.

Tabela 10 - Distribuição de freqüência absoluta para base de agrupamento

\begin{tabular}{|l|c|c|c|}
\hline Base de Agrupamento & Funcional & Por Mercado & Matricial \\
\hline Freqüência absoluta observada & 6 & 18 & 10 \\
\hline Freqüência absoluta esperada & 11,33 & 11,33 & 11,33 \\
\hline
\end{tabular}

Com base nas informações da Tabela 10 realizou-se um teste $\chi^{2}$ (qui-quadrado):

(1) $\mathrm{H}_{0}$ - não há discrepância entre as freqüências para os três tipos de estruturas; $\mathrm{H}_{1}$ - há discrepância;

(2) Nível de significância $\alpha=0,05$ e escolher a variável qui-quadrado $\operatorname{com} \varphi=2$;

(3) Valor crítico: 5,991; 
(4) Cálculo da variável $\chi^{2}$ (qui-quadrado);

$\chi_{\text {cal }}{ }^{2}=\frac{(6-11,33)^{2}}{11,33}+\frac{(18-11,33)^{2}}{11,33}+\frac{(9-11,33)^{2}}{11,33}=6,588$

(5) Conclusão - tendo sido $\chi_{\text {cal }}^{2}>\chi^{2}$ tab, foi possível rejeitar $\mathrm{H}_{0}$.

Havendo discrepâncias entre freqüências observadas e esperadas, pode-se afirmar que existe pelo menos uma base de agrupamento privilegiada. Ao se tomar por base as freqüências absolutas, nota-se que aproximadamente $53 \%$ dessas entidades utilizam o agrupamento por mercado, mais especificamente, por projetos, áreas temáticas ou programas.

Para o parâmetro tamanho da unidade realizou-se, primeiramente, a construção da distribuição de freqüência absoluta para cúpula estratégica, núcleo operacional e restante da entidade, compreendendo tecnoestrutura, assessoria de apoio e linha intermediária. Em seguida, foram identificadas quantas entidades estavam em cada intervalo da distribuição. As intensidades foram: 'pequena', 'média' e 'grande'. Por fim, foram calculadas as freqüências relativas ponderadas para cada nível.

As Tabelas 11, 12 e 13 apresentam os resultados.

Tabela 11 - Distribuição de freqüência absoluta para tamanho da Cúpula Estratégica

\begin{tabular}{|l|l|c|c|c|c|c|}
\hline \multicolumn{1}{|c|}{ Maior Tamanho } & \multicolumn{1}{|c|}{ Menor Tamanho } & Intervalo & $\mathbf{N}^{\mathbf{0}}$ de Classes & Amplitude & & \\
\hline 28 gestores & \multicolumn{1}{|c|}{ gestores } & 26 & 3 & 8,67 & & \\
\hline Intervalos & & & & & Qtde & $\%$ \\
\hline Média & Limite Inferior & 2 & Limite Superior & 10,67 & 30 & 88,24 \\
\hline Grande & Limite Inferior & 10,67 & Limite Superior & 19,33 & 3 & 8,82 \\
\hline Total & Limite Inferior & 19,33 & Limite Superior & 28 & 1 & 2,94 \\
\hline
\end{tabular}

Tabela 12 - Distribuição de freqüência absoluta para tamanho do Núcleo Operacional

\begin{tabular}{|l|l|c|l|c|c|c|}
\hline \multicolumn{1}{|c|}{ Maior Tamanho } & \multicolumn{1}{|c|}{ Menor Tamanho } & Intervalo & $\mathbf{N}^{\mathbf{0}}$ de Classes & Amplitude & & \\
\hline 89 colaboradores & \multicolumn{1}{|c|}{ 0 colaborador } & 89 & 3 & 29,67 & & \\
\hline Intervalos & & & & & Qtde & \% \\
\hline Pequena & Limite Inferior & 0 & Limite Superior & 29,67 & 29 & 85,29 \\
\hline Média & Limite Inferior & 29,67 & Limite Superior & 59,33 & 3 & 8,82 \\
\hline Grande & Limite Inferior & 59,33 & Limite Superior & 89 & 2 & 5,88 \\
\hline Total & & & & 34 & 100 \\
\hline
\end{tabular}

Tabela 13 - Distribuição de freqüência absoluta para tamanho do Restante da Entidade

\begin{tabular}{|l|l|c|c|c|c|c|}
\hline \multicolumn{1}{|c|}{ Maior Tamanho } & \multicolumn{1}{|c|}{ Menor Tamanho } & Intervalo & $\mathbf{N}^{\mathbf{0}}$ de Classes & Amplitude & & \\
\hline 86 colaboradores & \multicolumn{1}{|c|}{ 0 colaborador } & 86 & 3 & 28,67 & & \\
\hline Intervalos & & & & & Qtde & \% \\
\hline Pequena & Limite Inferior & 0 & Limite Superior & 28,67 & 28 & 82,35 \\
\hline Média & Limite Inferior & 28,67 & Limite Superior & 57,33 & 2 & 5,88 \\
\hline Grande & Limite Inferior & 57,33 & Limite Superior & 86 & 4 & 11,76 \\
\hline Total & & & & 34 & 100 \\
\hline
\end{tabular}


Considerou-se a intensidade 'pequena' como a categoria máxima de apresentação do evento e sua unidade de apresentação ' 1 '. Essas informações resultaram na seguinte codificação: pequena $=1$, média $=0$ e grande $=-1$.

$$
\begin{aligned}
& \text { CúpulaEstratégica }=\frac{1 \times 88,24+0 \times 8,82+(-1) \times 2,94}{100}=0,8530 \\
& \text { NúcleoOperacional }=\frac{1 \times 85,29+0 \times 8,82+(-1) \times 5,88}{100}=0,7941 \\
& \text { Re } s \tan t e E n t i d a d e=\frac{1 \times 82,35+0 \times 5,88+(-1) \times 11,76}{100}=0,7059
\end{aligned}
$$

As ONGs apresentam pequenas unidades administrativas, sendo a cúpula estratégica a menor, enquanto que o restante da entidade possui unidades maiores. Esse fato é decorrência, principalmente, do tamanho da assessoria de apoio, pois $76,47 \%$ das entidades apresentam entre nenhum e três membros na tecnoestrutura, enquanto na linha intermediária essa percentagem cai para 67,65 .

Para o parâmetro descentralização vertical e horizontal identificou-se quem participava do processo de tomada de decisão e em qual parte da organização se localizava. Com base nessas informações, foi possível identificar a intensidade de ocorrência da descentralização vertical e horizontal. As intensidades - 'muito', 'medianamente' e 'pouco' - foram utilizadas para cada dimensão da descentralização. Muita intensidade nas duas dimensões indica descentralização pura, enquanto pouca descentralização nas duas dimensões indica centralização. Em seguida, foram calculadas as freqüências relativas ponderadas.

A Tabela 14 apresenta as freqüências para cada dimensão da descentralização e para cada intensidade.

\section{Tabela 14 - Distribuição de freqüência absoluta para a descentralização em suas duas dimensões}

\begin{tabular}{|l|c|c|c|c|c|c|c|}
\hline & Muito & \% & Limitada & \% & Pouco & \% & Total \\
\hline Descentralização Vertical & 20 & 58,82 & 8 & 23,53 & 6 & 17,65 & 34 \\
\hline Descentralização Horizontal & 6 & 17,65 & 7 & 20,59 & 21 & 61,76 & 34 \\
\hline
\end{tabular}

Considerou-se a intensidade 'muito' como a categoria máxima de apresentação do evento e sua unidade de apresentação ' 1 '. Essas informações resultaram na seguinte codificação: muito $=1$, limitado $=0$ e pouco $=-1$. 


$$
\begin{aligned}
& \text { DescentrVertical }=\frac{1 \times 58,82+0 \times 23,53+(-1) \times 17,65}{100}=0,4117 \\
& \text { DescentHorizontal }=\frac{1 \times 17,65+0 \times 20,59+(-1) \times 61,76}{100}=-0,4411
\end{aligned}
$$

As ONGs pesquisadas apresentam muita descentralização vertical e pouca descentralização horizontal, significando que o poder de tomada de decisões concentra-se na cúpula estratégica, o qual é dividido em muitas entidades, com o núcleo operacional. Por outro lado, pouco poder de tomada de decisão é transferido para a assessoria de apoio ou, principalmente, para a tecnoestrutura.

Os fatores situacionais passam por processos de análise semelhantes. $\mathrm{O}$ fator situacional ambiente é analisado em suas quatro dimensões: estabilidade, complexidade, diversidade de mercado e hostilidade, buscando-se, assim, identificar com qual intensidade cada uma dessas dimensões ocorre em cada ONG. Para tanto foi apresentada uma escala de cinco níveis numerada de 1 a 5. Os graus ' 1 ' e '2', para a dimensão estabilidade, representaram proximidade de 'estável', para a dimensão complexidade, proximidade de 'simples', para a dimensão diversidade de mercado, proximidade de 'integrado', para a dimensão hostilidade, proximidade de 'magnânimo'. Por outro lado, os graus '4' e '5', para a dimensão estabilidade, representaram proximidade de 'dinâmico', para a dimensão complexidade, proximidade de 'complexo', para a dimensão diversidade de mercado, proximidade de 'diversificado', para a dimensão hostilidade, proximidade de 'hostilidade'. Por fim, o grau ' 3 ' representou neutralidade, ou seja, para a dimensão estabilidade, proximidade de 'nem estável nem dinâmica', para a dimensão complexidade, proximidade de 'nem simples nem complexo', para a dimensão diversidade de mercado, proximidade de 'nem integrado nem diversificado', para a dimensão hostilidade, proximidade de 'nem magnânimo nem hostil'. Identificadas as intensidades de cada dimensão ambiental, foram calculadas as freqüências relativas ponderadas.

A Tabela 15 apresenta as distribuições de freqüências encontradas.

\section{Tabela 15 - Distribuição de freqüência para as dimensões ambientais}

\begin{tabular}{|l|c|c|c|c|c|c|}
\hline Dimensões ambientais & Graus 1 e 2 & \% & Grau 3 & \% & Graus 4 e 5 & \% \\
\hline Estabilidade & 17 & 50,00 & 3 & 8,82 & 14 & 41,18 \\
\hline Complexidade & 7 & 20,59 & 8 & 23,53 & 19 & 55,88 \\
\hline Diversidade de Mercado & 20 & 58,82 & 5 & 14,71 & 9 & 26,47 \\
\hline Hostilidade & 12 & 35,29 & 6 & 17,65 & 16 & 47,06 \\
\hline
\end{tabular}


As intensidades ' 1 e 2' foram consideradas como a categoria máxima de apresentação do evento e sua unidade de apresentação ' 1 '. Essas informações resultaram na seguinte codificação: graus ' 1 e 2 ' $=1$, grau ' 3 ' $=0$ e graus ' 4 e 5 ' $=-1$.

$$
\begin{aligned}
& \text { Estabilidade }=\frac{1 \times 50+0 \times 8,82+(-1) \times 41,18}{100}=0,0882 \\
& \text { Complexidade }=\frac{1 \times 20,59+0 \times 23,53+(-1) \times 55,88}{100}=-0,3529 \\
& \text { DiversidadedeMercado }=\frac{1 \times 58,82+0 \times 14,71+(-1) \times 26,47}{100}=0,3235 \\
& \text { Hostilidade }=\frac{1 \times 35,29+0 \times 17,65+(-1) \times 47,06}{100}=-0,1177
\end{aligned}
$$

A percepção das entidades relativa às características do ambiente onde atuam é a de que ele não é estável nem dinâmico, é complexo, é integrado, e não é hostil nem magnânimo. Em função das incertezas, principalmente relacionadas às fontes de financiamento, uma parte das entidades considera seu ambiente dinâmico, enquanto que outra parte, considera-o estável porque possuem fontes de financiamento alternativas, ou porque existe a perspectiva de que as atuais fontes permaneçam financiando suas atividades. Ao mesmo tempo, a base de conhecimento necessária para a atuação da maior parte dessas entidades envolve um certo nível de complexidade. Ademais, ainda que algumas entidades tenham uma atuação geográfica diversificada ou possuam diversidade quanto às áreas de interesse, parece haver para a maior parte das ONGs pesquisadas - uma concentração das atividades tanto geográfica quanto temática. Por fim, essas entidades costumam encontrar boa receptividade principalmente de seus beneficiários, o que não impede a existência de hostilidade de segmentos diversos da sociedade.

Para os fatores situacionais 'idade e tamanho', foi construída, inicialmente, a distribuição de freqüências. Em seguida foram identificadas quantas entidades estavam em cada intervalo da distribuição. As intensidades utilizadas para o fator situacional 'idade' foram: 'jovem', 'nem jovem nem antiga' e 'antiga'. Para o fator situacional 'tamanho', foram: 'grande', 'nem grande nem pequena' e 'pequena', em função do número de colaboradores. Em seguida, foram calculadas as freqüências relativas ponderadas.

As Tabelas 16 e 17 apresentam os resultados para esses dois fatores situacionais. 
Tabela 16 - Distribuição de freqüência absoluta para o fator situacional idade

\begin{tabular}{|l|l|c|c|c|c|c|}
\hline \multicolumn{1}{|c|}{ Maior Idade } & \multicolumn{1}{|c|}{ Menor Idade } & Intervalo & $\mathbf{N}^{\mathbf{0}}$ de Classes & Amplitude & & \\
\hline \multicolumn{1}{|c|}{42 anos } & 11 anos & 31 & 3 & 10,33 & & \\
\hline Intervalos & & & & & Qtde & $\%$ \\
\hline Jovem & Limite Inferior & 11 & Limite Superior & 21,33 & 27 & 79,41 \\
\hline Nem Jovem Nem Antiga & Limite Inferior & 21,33 & Limite Superior & 31,67 & 4 & 11,77 \\
\hline Antiga & Limite Inferior & 31,67 & Limite Superior & 42 & 3 & 8,82 \\
\hline Total & & & & 34 & 100 \\
\hline
\end{tabular}

Tabela 17 - Distribuição de frequiência absoluta para o fator situacional tamanho

\begin{tabular}{|c|c|c|c|c|c|c|}
\hline Maior Tamanho & Menor Tamanho & Intervalo & $\mathrm{N}^{0}$ de Classes & Amplitude & & \\
\hline 149 colaboradores & 12 colaboradores & 137 & 3 & 45,67 & & \\
\hline Intervalos & & & & & Qtde & $\%$ \\
\hline Pequena & Limite Inferior & 12 & Limite Superior & 57,67 & 28 & 82,35 \\
\hline $\begin{array}{l}\text { Nem Pequena Nem } \\
\text { Grande }\end{array}$ & Limite Inferior & 57,67 & Limite Superior & 103,33 & 2 & 5,88 \\
\hline Grande & Limite Inferior & 103,33 & Limite Superior & 149 & 4 & 11,77 \\
\hline Total & & & & & 34 & 100 \\
\hline
\end{tabular}

$\mathrm{Na}$ análise da freqüência relativa ponderada para o fator situacional idade, considerouse a intensidade 'jovem' como a categoria máxima de apresentação do evento e sua unidade de apresentação ' 1 '. Essas informações resultaram na seguinte codificação: jovem $=1$, nem jovem nem antiga $=0$ e antiga $=-1$.

$$
\text { Idade }=\frac{1 \times 79,41+0 \times 11,77+(-1) \times 8,82}{100}=0,7059
$$

Realizando a mesma análise para o fator situacional tamanho, considerou-se a intensidade 'pequena' como a categoria máxima de apresentação do evento e sua unidade de apresentação ' 1 '. Essas informações resultaram na seguinte codificação: pequena $=1$, nem pequena nem grande $=0$ e grande $=-1$.

$$
\text { Tamanho }=\frac{1 \times 82,35+0 \times 5,88+(-1) \times 11,77}{100}=0,7058
$$

Os resultados indicam que as ONGs pesquisadas são predominantemente pequenas e jovens.

Quanto ao fator situacional poder, analisou-se apenas a dimensão relacionada à existência de controle externo. As intensidades foram: 'sempre', 'ocasionalmente' e 'nunca'.

A Tabela 18 apresenta a distribuição de freqüência para o controle externo.

Tabela 18 - Distribuição de freqüência para controle externo

\begin{tabular}{|l|c|c|c|c|}
\hline Controle Externo & Sempre & Ocasionalmente & Nunca & Total \\
\hline Freqüência & 31 & 3 & 0 & 34 \\
\hline
\end{tabular}


Parece claro que o controle externo é um fator presente em todas as ONGs, cabendo às entidades de cooperação internacional o poder de exerce-lo com mais freqüência, seguidas pelo Governo - municipal, estadual e federal - e pelos associados. Esse controle se dá principalmente por meio da exigência de prestação de contas e apresentação de relatórios sobre as atividades desenvolvidas.

Quanto ao sistema técnico, constatou-se que as ONGs investigadas prestam serviços por meio dos próprios colaboradores, ou seja, com pouca utilização de sistema técnico, o que implica a apresentação de um sistema técnico simples e não regulado.

Com base nas informações das Tabelas 9 a 18, foi feita a análise da aderência conceitual de cada entidade relacionada às configurações das estruturas organizacionais propostas por Mintzberg $(2001 ; 2003)$, de forma a identificar qual a estrutura organizacional predominante em cada entidade e qual a estrutura organizacional prevalecente no conjunto. Para tanto, utilizou-se como referência as informações do Quadro 12 - síntese das dimensões das seis configurações organizacionais. Considerando os aspectos básicos identificados em cada $\mathrm{ONG}$, tais informações foram cruzadas com aquelas que constam no referido quadro, atribuindo-se valor ' 1 ' no caso de haver similaridade e valor ' 0 ' na ausência dessa similaridade. Se determinada $\mathrm{ONG}$, por exemplo, apresentou muita formalização do comportamento, foi atribuído valor ' 1 ' para os tipos organizacionais 'burocracia mecanizada' e 'forma divisionalizada' e valor ' 0 ' para os demais. Atribuídos os valores em todos os aspectos básicos para todos os arranjos organizacionais, procedeu-se à soma dos valores em cada um dos arranjos para, em seguida, dividir a referida soma pela quantidade de aspectos básicos considerados. O resultado dessa divisão representou a aderência conceitual de cada ONG para cada estrutura organizacional. Quanto mais o resultado se aproximou de 1, mais daquele tipo organizacional a entidade apresentou. Os aspectos básicos considerados foram: especialização horizontal, especialização vertical, formalização do comportamento, treinamento, doutrinação, planejamento das ações, controle de desempenho, agrupamento em unidade, tamanho da cúpula estratégica, tamanho do núcleo operacional, tamanho do restante da entidade, instrumentos de interligação, descentralização horizontal, descentralização vertical, idade, tamanho, estabilidade, complexidade, diversidade de mercado, hostilidade, sistema técnico e controle externo.

A Tabela 19 registra as aderências conceituais relativas às entidades entrevistadas, relacionando-as aos tipos organizacionais, e os valores máximos e mínimos, a média, a mediana, a moda e o desvio padrão para cada configuração organizacional. 
Tabela 19 - Aderências conceituas de cada ONG aos tipos organizacionais

\begin{tabular}{|c|c|c|c|c|c|c|}
\hline ONGs & $\begin{array}{c}\text { Estrutura } \\
\text { Simples } \\
\end{array}$ & $\begin{array}{r}\text { Burocracia } \\
\text { Mecanizada }\end{array}$ & $\begin{array}{l}\text { Burocracia } \\
\text { Profissional }\end{array}$ & $\begin{array}{c}\text { Forma } \\
\text { Divisionalizada }\end{array}$ & Adhocracia & Missionária \\
\hline 1 & 0,21 & 0,38 & 0,46 & 0,38 & 0,38 & 0,38 \\
\hline 2 & 0,25 & 0,25 & 0,42 & 0,29 & 0,54 & 0,50 \\
\hline 3 & 0,29 & 0,21 & 0,29 & 0,21 & 0,25 & 0,29 \\
\hline 4 & 0,46 & 0,29 & 0,42 & 0,29 & 0,38 & 0,54 \\
\hline 5 & 0,38 & 0,25 & 0,54 & 0,29 & 0,46 & 0,46 \\
\hline 6 & 0,25 & 0,25 & 0,42 & 0,21 & 0,46 & 0,38 \\
\hline 7 & 0,25 & 0,21 & 0,46 & 0,13 & 0,38 & 0,25 \\
\hline 8 & 0,38 & 0,17 & 0,46 & 0,13 & 0,50 & 0,38 \\
\hline 9 & 0,25 & 0,21 & 0,29 & 0,21 & 0,54 & 0,21 \\
\hline 10 & 0,33 & 0,21 & 0,42 & 0,29 & 0,50 & 0,50 \\
\hline 11 & 0,33 & 0,17 & 0,54 & 0,21 & 0,54 & 0,38 \\
\hline 12 & 0,21 & 0,21 & 0,50 & 0,17 & 0,38 & 0,50 \\
\hline 13 & 0,33 & 0,25 & 0,42 & 0,38 & 0,29 & 0,42 \\
\hline 14 & 0,33 & 0,21 & 0,42 & 0,21 & 0,50 & 0,42 \\
\hline 15 & 0,29 & 0,29 & 0,58 & 0,21 & 0,46 & 0,42 \\
\hline 16 & 0,29 & 0,25 & 0,46 & 0,25 & 0,38 & 0,42 \\
\hline 17 & 0,25 & 0,29 & 0,38 & 0,33 & 0,38 & 0,33 \\
\hline 18 & 0,17 & 0,29 & 0,38 & 0,21 & 0,33 & 0,46 \\
\hline 19 & 0,29 & 0,25 & 0,58 & 0,08 & 0,54 & 0,58 \\
\hline 20 & 0,33 & 0,21 & 0,42 & 0,29 & 0,46 & 0,42 \\
\hline 21 & 0,33 & 0,17 & 0,29 & 0,17 & 0,50 & 0,42 \\
\hline 22 & 0,42 & 0,29 & 0,42 & 0,17 & 0,54 & 0,63 \\
\hline 23 & 0,21 & 0,29 & 0,46 & 0,29 & 0,42 & 0,46 \\
\hline 24 & 0,21 & 0,33 & 0,54 & 0,21 & 0,50 & 0,54 \\
\hline 25 & 0,25 & 0,46 & 0,58 & 0,13 & 0,58 & 0,42 \\
\hline 26 & 0,33 & 0,17 & 0,42 & 0,08 & 0,50 & 0,46 \\
\hline 27 & 0,25 & 0,21 & 0,46 & 0,17 & 0,46 & 0,42 \\
\hline 28 & 0,21 & 0,29 & 0,38 & 0,17 & 0,50 & 0,42 \\
\hline 29 & 0,38 & 0,17 & 0,42 & 0,13 & 0,46 & 0,29 \\
\hline 30 & 0,33 & 0,17 & 0,50 & 0,08 & 0,58 & 0,50 \\
\hline 31 & 0,21 & 0,33 & 0,54 & 0,29 & 0,50 & 0,46 \\
\hline 32 & 0,50 & 0,29 & 0,50 & 0,29 & 0,38 & 0,46 \\
\hline 33 & 0,21 & 0,21 & 0,50 & 0,13 & 0,54 & 0,54 \\
\hline 34 & 0,33 & 0,17 & 0,46 & 0,17 & 0,46 & 0,46 \\
\hline Mínimo & 0,17 & 0,17 & 0,29 & 0,08 & 0,25 & 0,21 \\
\hline Máximo & 0,50 & 0,46 & 0,58 & 0,38 & 0,58 & 0,63 \\
\hline Moda & 0,33 & 0,21 & 0,42 & 0,21 e 0,29 & 0,50 & 0,42 \\
\hline Mediana & 0,29 & 0,25 & 0,46 & 0,21 & 0,46 & 0,42 \\
\hline Média & 0,30 & 0,25 & 0,45 & 0,21 & 0,46 & 0,43 \\
\hline Desvio Padrão & 0,076 & 0,065 & 0,076 & 0,080 & 0,080 & 0,088 \\
\hline
\end{tabular}

Formas divisionalizadas apresentam as menores proporções de aderência conceitual, enquanto que a maior proporção é apresentada por uma estrutura missionária. Em estruturas adhocráticas, a moda é superior às demais, o mesmo acontecendo com a média. A estrutura adhocrática e a burocracia profissional apresentam as maiores medianas, enquanto que, 
novamente, a forma divisionalizada apresenta a mediana mais baixa. Por fim, o maior desvio padrão é encontrado entre as aderências conceituais de estruturas missionárias e o menor na burocracia mecanizada.

A fim de comprovar a existência de diferenças entre as aderências conceituais aos tipos organizacionais, utilizou-se o teste de Kruskal-Wallis seguindo o procedimento abaixo:

(1) $\mathrm{H}_{0}$ - Não há diferença entre as proporções para os seis tipos;

$\mathrm{H}_{1}-$ Há pelo menos um par diferente;

(2) Nível de significância $\alpha=0,01$ e escolher a variável qui-quadrado $\operatorname{com} \varphi=5$;

(3) Valor crítico: 15,086;

(4) Cálculo da estatística $\mathrm{H}=127,180$;

(5) Conclusão - tendo sido $\mathrm{H}>\chi^{2}$ tab, foi possível rejeitar $\mathrm{H}_{0}$.

Pode-se afirmar que há pelo menos um par de médias de aderência conceitual que se distingue das demais. Voltando à analise das informações da Tabela 19, percebe-se - com base no valor médio - a existência de três tipos organizacionais que se destacam, a saber: adhocracia (46\%), burocracia profissional (45\%) e estrutura missionária (43\%). Entre os três, não se pode afirmar com segurança a predominância de um sobre os outros, tendo em vista as pequenas diferenças entre elas. Dessa forma, considera-se a existência de três tipos organizacionais predominantes entre as ONGs pesquisadas, dentro da tipologia original de Mintzberg (2001; 2003). Por outro lado, a forma divisionalizada é o tipo organizacional do qual essas entidades mais se afastam. Ressalta-se que existem características organizacionais que estão presentes em mais de um tipo organizacional, o que justifica a soma dos valores médios das aderências conceituais ser superior a $100 \%$.

De fato, constatou-se que os três parâmetros de design que ocorrem com maior freqüência absoluta são doutrinação, treinamento e instrumentos de interligação. O primeiro representa o parâmetro que melhor caracteriza estruturas missionárias, o segundo o que melhor caracteriza burocracias profissionais e o terceiro o que melhor caracteriza adhocracias. Ademais, constatou-se pouca especialização vertical das tarefas, agrupamento preferencialmente por mercado e descentralização vertical, características presentes nesses três tipos organizacionais. Quanto aos fatores situacionais, o ambiente complexo caracteriza burocracias profissionais e adhocracias, enquanto o ambiente relativamente estável caracteriza burocracias profissionais e missionárias. Adhocracias e estruturas missionárias são tipicamente jovens, idade predominante entre as ONGs pesquisadas. O tamanho é determinante apenas nas estruturas missionárias que são pequenas, enquanto que nos dois outros tipos esse critério é indiferente. Por fim, pode-se afirmar que não existe um único tipo 
organizacional predominante entre as ONGs. Existindo outras características organizacionais não consistentes com qualquer dos três arranjos predominantes - muito planejamento das ações e propensão para muito controle de desempenho -, as estruturas organizacionais dessas entidades, considerando a tipologia original de Mintzberg (2001; 2003), não representam configurações puras.

A Tabela 20 apresenta a quantidade de entidades em cada tipo de estrutura organizacional. Para tanto, utilizou-se como base as aderências conceituais exibidas na Tabela 19. O tipo organizacional predominante em cada ONG foi aquele que apresentou maior aderência conceitual, ocorrendo, em alguns casos, o fato de uma ONG apresentar aderências conceituais iguais para mais de uma estrutura organizacional, caracterizando estruturas híbridas, tipo não considerado neste estudo. Para identificar a estrutura predominante nesses casos, escolheu-se o ambiente em suas dimensões 'estabilidade' e 'complexidade' como critério de desempate. Permanecendo a igualdade, foi escolhido um parâmetro de design que melhor caracterizasse cada tipo organizacional para, em seguida, analisar-se a intensidade com que ocorria. Para estruturas simples, escolheu-se a existência de centralização; para burocracias mecanizadas, a existência de muita formalização; para burocracias profissionais, a existência de muito treinamento; para formas divisionalizadas, a existência de muito controle de desempenho; para adhocracias, a existência de pouca formalização; e para organizações missionárias, a existência de muita doutrinação. Permanecendo ainda a igualdade, a especialização das tarefas foi utilizada para a identificação da estrutura organizacional predominante da ONG.

Tabela 20 - Identificação da quantidade de ONGs em cada configuração organizacional

\begin{tabular}{|l|c|c|c|c|c|c|}
\hline $\begin{array}{l}\text { Estruturas } \\
\text { Organizacionais }\end{array}$ & $\begin{array}{c}\text { Estrutura } \\
\text { Simples }\end{array}$ & $\begin{array}{c}\text { Burocracia } \\
\text { Mecanizada }\end{array}$ & $\begin{array}{c}\text { Burocracia } \\
\text { Profissional }\end{array}$ & $\begin{array}{c}\text { Forma } \\
\text { Divisionalizada }\end{array}$ & $\begin{array}{c}\text { Adho- } \\
\text { cracia }\end{array}$ & $\begin{array}{c}\text { Organização } \\
\text { Missionária }\end{array}$ \\
\hline Quantidade de ONGs & 1 & 0 & 15 & 0 & 13 & 5 \\
\hline
\end{tabular}

Pelos critérios de desempate adotados, constata-se que 44,11\% das ONGs se aproximam de burocracias profissionais, enquanto que 38,24\% se aproximam de adhocracias, $14,71 \%$ de estruturas missionárias e 2,94\% de estruturas simples. É preciso considerar que as mudanças dos critérios de desempate podem provocar mudanças nessa composição. Interessante observar a composição dos fatores preponderantes na determinação da estrutura organizacional dessas entidades.

A Tabela 21 apresenta as freqüências observadas de cada fator considerado. 
Tabela 21 - Composição dos fatores predominantes na determinação da estrutura organizacional das ONGs

\begin{tabular}{|l|c|c|c|c|c|c|}
\hline Fator Predominante & Ambiente & $\begin{array}{c}\text { Controle } \\
\text { Externo }\end{array}$ & Consistência & Moda & Ideologia & Poder \\
\hline Freqüência absoluta observada & 1 & 0 & 17 & 0 & 13 & 3 \\
\hline
\end{tabular}

Com base nas freqüências absolutas, percebe-se que 50\% das entidades investigadas definiram sua estrutura organizacional buscando a consistência entre parâmetros de design e fatores situacionais, enquanto que $38,24 \%$ realizaram essa definição tendo por base a ideologia presente, ou seja, sua missão, $8,82 \%$ por quem tinha o poder de decisão e $2,94 \%$ tiveram o ambiente como o fator preponderante nessa definição.

Considerando a consistência como o principal fator na determinação da estrutura organizacional e a inexistência de somente um tipo organizacional preponderante entre as ONGs pesquisadas - dentro da tipologia original de Mintzberg (2001; 2003) - pode-se conjeturar a existência de um tipo organizacional específico para as ONGs pesquisadas, não contemplado na referida tipologia, mas, igualmente às demais configurações, apresentando consistência entre os aspectos básicos.

\subsection{Análise da Relação entre o Tipo Organizacional a Área de Atuação, a Idade, o Tamanho e a Composição das Receitas}

$\mathrm{Na}$ análise das áreas de atuação, foram considerados quatro setores: educação/pesquisa, sócio-ambientais, discriminação racial e de gênero e defesa de direitos. Nessa última categoria, foram incluídas as entidades que defendiam direitos de crianças, jovens e adolescentes, consumidores, pessoas com transtornos mentais e pessoas portadoras de doenças sexualmente transmissíveis. É preciso ressaltar que existem ONGs que atuam em mais de uma dessas áreas, podendo mesmo atuar nas quatro.

A Tabela 22 apresenta os dados observados.

Tabela 22 - Relacionamento entre estruturas organizacionais e área de atuação

\begin{tabular}{|l|c|c|c|c|c|}
\hline \multirow{2}{*}{ Tipos Organizacionais } & \multicolumn{5}{|c|}{ Áreas de Atuação } \\
\cline { 2 - 7 } & Educação/Pesquisa & $\begin{array}{c}\text { Sócio- } \\
\text { Ambientais }\end{array}$ & $\begin{array}{c}\text { Discriminação Racial } \\
\text { e/ou de Gênero }\end{array}$ & $\begin{array}{c}\text { Defesa de } \\
\text { Direitos }\end{array}$ & Total \\
\hline Estrutura Simples & 0 & 0 & 0 & 1 & $\mathbf{1}$ \\
\hline Burocracia Profissional & 7 & 2 & 6 & 0 & $\mathbf{1 5}$ \\
\hline Adhocracia & 2 & 4 & 2 & 3 & $\mathbf{1 3}$ \\
\hline Missionária & 1 & 0 & 1 & $\mathbf{9}$ & $\mathbf{3 4}$ \\
\hline Total & $\mathbf{1 0}$ & $\mathbf{5}$ & $\mathbf{9}$ & $\mathbf{5}$ & \\
\hline
\end{tabular}


As ONGs próximas de burocracias profissionais estão relacionadas, principalmente, com as áreas de educação/pesquisa e discriminação racial e/ou de gênero. As ONGs que se aproximam de adhocracias, por sua vez, estão relacionadas, principalmente, com a área de defesa de direitos e sócio-ambientais. As organizações que se aproximam de estruturas missionárias estão relacionadas, principalmente, com defesa de direitos.

O relacionamento entre estruturas organizacionais e idades pode ser observado na Tabela 23. Para a classificação da idade foram utilizadas as informações da Tabela 16.

Tabela 23 - Relacionamento entre estruturas organizacionais e idade

\begin{tabular}{|l|c|c|c|c|c|c|c|}
\hline \multirow{2}{*}{ Tipos Organizacionais } & \multicolumn{9}{|c|}{ Idade } \\
\cline { 2 - 9 } & Jovem & $\%$ & Média & $\%$ & Antiga & $\%$ & Total \\
\hline Estrutura Simples & 1 & 100 & 0 & 0 & 0 & 0 & 1 \\
\hline Burocracia Profissional & 10 & 66,67 & 2 & 13,33 & 3 & 20,00 & 15 \\
\hline Adhocracia & 12 & 92,31 & 1 & 7,69 & 0 & 0 & 13 \\
\hline Missionária & 4 & 80,00 & 1 & 20,00 & 0 & 0 & 5 \\
\hline Total & 27 & & 4 & & 3 & & 34 \\
\hline
\end{tabular}

Os quatro tipos organizacionais relacionam-se com jovens entidades. Esse resultado é verdadeiro, principalmente, para ONGs próximas de adhocracias e de missionárias, confirmando a teoria de Mintzberg $(2001,2003)$, para quem tais estruturas organizacionais são tipicamente jovens. Apenas três ONGs, todas se aproximando de burocracias profissionais, apresentam idade antiga. Tal fato também confirma a teoria de Mintzberg (2001, 2003), pois a idade não representa um fator determinante para esse tipo organizacional.

Relacionando estruturas organizacionais com tamanho, foram observados os dados que constam na Tabela 24. Para a classificação do tamanho foram utilizadas as informações da Tabela 17.

Tabela 24 - Relacionamento entre estruturas organizacionais e tamanho

\begin{tabular}{|l|c|c|c|c|c|c|c|}
\hline \multirow{2}{*}{ Tipos Organizacionais } & \multicolumn{9}{c|}{ Idade } \\
\cline { 2 - 9 } & Pequena & $\%$ & Média & $\%$ & Grande & $\%$ & Total \\
\hline Estrutura Simples & 1 & 100 & 0 & 0 & 0 & 0 & 1 \\
\hline Burocracia Profissional & 12 & 80,00 & 0 & 0 & 3 & 20,00 & 15 \\
\hline Adhocracia & 10 & 76,92 & 2 & 15,38 & 1 & 7,70 & 13 \\
\hline Missionária & 5 & 100 & 0 & 0 & 0 & 0 & 5 \\
\hline Total & 28 & & 2 & & 4 & & 34 \\
\hline
\end{tabular}

Os quatro tipos organizacionais relacionam-se com entidades pequenas. Esse resultado é mais notado para as ONGs próximas de estruturas missionárias, pois todas apresentam pequeno tamanho, confirmando a teoria de Mintzberg $(2001,2003)$, para quem entidades com esse tipo organizacional tendem a ser pequenas. Apenas três ONGs, duas próximas de 
burocracias profissionais e uma de adhocracia, apresentam tamanho grande. Tal fato também confirma a teoria de Mintzberg $(2001,2003)$, pois o tamanho não representa um fator determinante para esses tipos organizacionais.

Analisando em conjunto as variáveis idade e tamanho, conclui-se que 20 ONGs $(58,82 \%)$ são jovens e pequenas, sendo sete próximas de burocracias profissionais, oito de adhocracias, quatro de estruturas missionárias e uma de estruturas simples. Por outro lado, constata-se que nenhuma das entidades pesquisadas é grande e antiga. As demais apresentam as seguintes características: quatro $(11,77 \%)$ entidades são jovens e grandes - três que se aproximam de burocracias profissionais e uma de adhocracia -; três $(8,82 \%)$ ONGs são antigas e pequenas, todas se aproximando de burocracias profissionais; quatro $(11,77 \%)$ são pequenas e de idade média - sendo que duas se aproximam de burocracias profissionais, uma de adhocracias e uma de estruturas missionárias -; e outras três $(8,82 \%)$ são jovens e de tamanho médio, todas se aproximando de adhocracias.

O relacionamento entre estruturas organizacionais e composição das receitas é apresentado na Tabela 25. Destaca-se que as porcentagens representam o valor médio para cada tipo organizacional e respectiva fonte de receitas.

Tabela 25 - Relacionamento entre estruturas organizacionais e composição das receitas

\begin{tabular}{|l|c|c|c|c|c|c|c|}
\hline \multirow{2}{*}{$\begin{array}{c}\text { Tipos } \\
\text { Organizacionais }\end{array}$} & \multicolumn{7}{|c|}{ Fontes de Receitas (\%) } \\
\cline { 2 - 8 } & $\begin{array}{c}\text { Doações } \\
\text { Individuais }\end{array}$ & $\begin{array}{c}\text { Fundações } \\
\text { Internacionais }\end{array}$ & $\begin{array}{c}\text { Fundações } \\
\text { Nacionais }\end{array}$ & Governo & $\begin{array}{c}\text { Prestação de } \\
\text { Serviços }\end{array}$ & Outras & Total \\
\hline Estrutura Simples & 27,27 & 0,00 & 0,00 & 0,00 & 72,73 & 0,00 & 100 \\
\hline Burocracia Profissional & 0,57 & 68,75 & 4,97 & 16,22 & 7,65 & 1,83 & 100 \\
\hline Adhocracia & 14,15 & 39,56 & 13,54 & 18,71 & 11,13 & 2,92 & 100 \\
\hline Missionária & 5,82 & 18,48 & 18,38 & 55,82 & 0,92 & 0,58 & 100 \\
\hline
\end{tabular}

Mais de $68 \%$ das fontes de receitas de entidades próximas de burocracias profissionais provêm de agências internacionais, enquanto que as demais se originam, principalmente, de entidades governamentais e prestação de serviços. As ONGs próximas de adhocracias apresentam maior diversificação, pois ainda que exista forte presença de recursos de fundações internacionais $(39,56 \%)$, há também doações individuais, recursos de entidades governamentais, da prestação de serviços e de fundações nacionais. Entidades próximas de missionárias, por sua vez, apresentam a maior parte de seus recursos $(55,82 \%)$ oriundos de entidades governamentais. A entidade próxima da estrutura simples apresenta a prestação de serviços como principal fonte de recursos $(72,73 \%)$.

A presença de muitos recursos financeiros originários de fundações internacionais em ONGs que se aproximam de burocracias profissionais pode ser o motivo de sua maior 
formalização, no caso, por meio da padronização das habilidades. Esse pensamento pode ser válido para entidades próximas de adhocracias, sendo que em proporção menor, ou seja, menos formalização. Por outro lado, a presença de poucos recursos financeiros provenientes de fundações internacionais em ONGs próximas de estruturas missionárias pode ser a causa da pouca formalização existente nesse tipo organizacional, tendo em vista que o controle exercido por agências internacionais ocorre com maior intensidade do que o exercido por entidades governamentais, pois aquelas exercem controle externo com intensidade 'sempre' em aproximadamente $56 \%$ da ONGs pesquisadas, enquanto que esse mesmo controle exercido pelas entidades governamentais ocorre em aproximadamente $41 \%$ dessas ONGs.

\subsection{Análise dos Indicadores de Desempenho}

A análise dos indicadores de desempenho das ONGs considera os aspectos quantitativos e qualitativos. Os primeiros foram analisados por meio de quatro índices: 1) aplicação de recursos na atividade meio, calculado pelo quociente entre despesa administrativa (incluindo pessoal administrativo) e despesa total; 2) aplicação dos recursos na atividade fim, calculado pelo quociente entre despesas com projetos mais despesas com pessoal e despesa total; 3) produtividade de mão-de-obra, calculado pelo quociente entre receita total e quantidade de colaboradores; e 4) produtividade de capital, calculado pelo quociente entre receita total e despesa total. Para o cálculo dos índices de produtividade também foi utilizado o número de beneficiários diretos como medida de resultado no lugar do valor da receita total. Ademais, para o cálculo da produtividade de mão-de-obra foram consideradas tanto as quantidades totais de colaboradores como essas quantidades reduzidas

pelos membros voluntários. Os aspectos qualitativos foram analisados por meio da identificação dos fatores com os quais as entidades estão comprometidas no sentido de prestar serviços de qualidade para satisfazer seus beneficiários.

Para a análise quantitativa foram construídas distribuições de freqüências das principais variáveis. Das 34 entidades respondentes, 26 (82,35\%) forneceram informações para o cálculo dos índices. A Tabela 26 apresenta os resultados encontrados para o índice de aplicação dos recursos na atividade meio, calculado pelo quociente entre despesas administrativas (incluindo pessoal administrativo) e despesa total. 
Tabela 26 - Distribuição de freqüência do índice de aplicação dos recursos na atividade meio

\begin{tabular}{|l|c|c|c|c|c|c|}
\hline Maior Valor & Menor Valor & Intervalo & $\mathbf{N}^{\mathbf{0}}$ de Classes & Amplitude & & \\
\hline \multicolumn{1}{|c|}{1,0000} & 0,0078 & 0,9922 & 3 & 0,3307 & & \\
\hline Intervalos & & & & & Qtde & $\%$ \\
\hline Baixo & Limite Inferior & 0,0078 & Limite Superior & 0,3385 & 18 & 64,29 \\
\hline Médio & Limite Inferior & 0,3385 & Limite Superior & 0,6693 & 7 & 25,00 \\
\hline Alto & Limite Inferior & 0,6693 & Limite Superior & 1,0000 & 3 & 10,71 \\
\hline
\end{tabular}

A categoria máxima de apresentação do evento foi 'baixo' e sua unidade de apresentação ' 1 '. Essas informações resultaram na seguinte codificação: baixo $=1$, médio $=0$ e alto $=-1$. Fazendo o cálculo da freqüência relativa ponderada, chega-se a 0,5358.

frequênciarelativaponderada $=\frac{(1 \times 64,29+0 \times 25+(-1) \times 10,71)}{100}=0,5358$

O resultado indica tendência de baixo índice de aplicação dos recursos na atividade meio. Ainda que para as entidades seja importante esse tipo de atividade, quanto mais recursos são gastos em despesas dessa natureza, menos serão gastos na atividade fim.

O segundo índice analisado foi o índice de aplicação dos recursos na atividade fim, calculado pelo quociente entre a soma de despesas de pessoal com despesas de projetos e a despesa total. A Tabela 27 apresenta os resultados encontrados.

Tabela 27 - Distribuição de freqüência do índice de aplicação dos recursos na atividade fim

\begin{tabular}{|c|c|c|c|c|c|c|}
\hline Maior Valor & Menor Valor & Intervalo & $\mathrm{N}^{0}$ de Classes & Amplitude & & \\
\hline 0,9922 & 0,0000 & 0,9922 & 3 & 0,3307 & & \\
\hline Intervalos & & & & & Qtde & $\%$ \\
\hline Baixo & Limite Inferior & 0,0000 & Limite Superior & 0,3307 & 4 & 14,29 \\
\hline Médio & Limite Inferior & 0,3307 & Limite Superior & 0,6615 & 9 & 32,14 \\
\hline Alto & Limite Inferior & 0,6615 & Limite Superior & 0,9922 & 15 & 53,57 \\
\hline
\end{tabular}

A categoria máxima de apresentação do evento foi 'baixo' e sua unidade de apresentação '-1'. Essas informações resultaram na seguinte codificação: baixo $=-1$, médio = 0 e alto $=1$. Fazendo o cálculo da freqüência relativa ponderada, chega-se a 0,3928.

$$
\text { frequênciocelativaponderada }=\frac{((-1) \times 14,29+0 \times 32,14+1 \times 53,57)}{100}=0,3928
$$

O resultado indica tendência de alto índice de aplicação dos recursos na atividade fim. Esse resultado significa que as entidades utilizam alto volume dos recursos que possuem na prestação dos serviços, reforçando o resultado encontrado para o índice anterior. 
O terceiro índice analisado foi o de produtividade de mão-de-obra, calculado pelo quociente entre receita total e quantidade de colaboradores. A Tabela 28 apresenta os resultados encontrados.

Tabela 28 - Distribuição de frequiência do índice de produtividade de mão-de-obra

\begin{tabular}{|l|c|c|c|c|c|c|}
\hline Maior Valor & Menor Valor & Intervalo & $\mathbf{N}^{\mathbf{0}}$ de Classes & Amplitude & & \\
\hline $168.542,50$ & 356,76 & $168.185,74$ & 3 & $56.061,91$ & & \% \\
\hline Intervalos & & & & & Qtde & 78,57 \\
\hline Baixo & Limite Inferior & 356,76 & Limite Superior & $56.418,67$ & 22 & 17,86 \\
\hline Médio & Limite Inferior & $56.418,67$ & Limite Superior & $112.480,59$ & 5 & 3,57 \\
\hline Alto & Limite Inferior & $112,480,59$ & Limite Superior & $168.542,50$ & 1 & \\
\hline
\end{tabular}

A categoria máxima de apresentação do evento foi 'baixo' e sua unidade de apresentação '-1'. Essas informações resultaram na seguinte codificação: baixo $=-1$, médio = 0 e alto $=1$. Fazendo o cálculo da freqüência relativa ponderada, chega-se a 0,7500 .

frequênciacelativaponderada $=\frac{((-1) \times 78,57+0 \times 17,86+1 \times 3,57)}{100}=-0,7500$

O resultado indica tendência de baixo índice de produtividade de mão-de-obra.

Calculando-se esse mesmo índice pelo quociente entre receita total e quantidade de colaboradores - excluindo-se os que são voluntários - obtiveram-se, conforme apresentado na Tabela 29, os seguintes resultados:

Tabela 29 - Distribuição de freqüência do índice de produtividade de mão-de-obra, exceto voluntários

\begin{tabular}{|l|c|c|c|c|c|c|}
\hline Maior Valor & Menor Valor & Intervalo & $\mathbf{N}^{\mathbf{0}}$ de Classes & Amplitude & & \\
\hline 229.217,80 & $6.553,10$ & $222.664,71$ & 3 & $74.221,57$ & & Qtde \\
\hline Intervalos & & & & & & 67,86 \\
\hline Baixo & Limite Inferior & $6.553,10$ & Limite Superior & $80.774,66$ & 19 & 21,43 \\
\hline Médio & Limite Inferior & $80.774,66$ & Limite Superior & $154.996,23$ & 6 & 10,71 \\
\hline Alto & Limite Inferior & $154.996,23$ & Limite Superior & $229.217,80$ & 3 & \\
\hline
\end{tabular}

A categoria máxima de apresentação do evento foi 'baixo' e sua unidade de apresentação '-1'. Essas informações resultaram na seguinte codificação: baixo $=-1$, médio = 0 e alto $=1$. Fazendo o cálculo da freqüência relativa ponderada, chega-se a 0,5715.

frequênciarelativaponderada $=\frac{((-1) \times 67,86+0 \times 21,43+1 \times 10,71)}{100}=-0,5715$

Esse resultado corrobora o anterior ao indicar baixa produtividade de mão-de-obra. 
A Tabela 30 apresenta os resultados para o índice de produtividade de mão-de-obra calculado pelo quociente entre número de beneficiários diretos e quantidade de colaboradores. O número de observações para o cálculo desse índice foi de 24 , pois em algumas entidades tornou-se impossível a identificação dos beneficiários diretos.

Tabela 30 - Distribuição de freqüência do índice de produtividade de mão-de-obra utilizando o 'número de beneficiários diretos'

\begin{tabular}{|c|c|c|c|c|c|c|}
\hline Maior Valor & Menor Valor & Intervalo & $\mathrm{N}^{0}$ de Classes & Amplitude & & \\
\hline $5.952,38$ & 12,92 & $5.939,46$ & 3 & $1.979,82$ & & \\
\hline Intervalos & & & & & Qtde & $\%$ \\
\hline Baixo & Limite Inferior & 12,92 & Limite Superior & $1.992,74$ & 21 & 87,50 \\
\hline Médio & Limite Inferior & $1.992,74$ & Limite Superior & $3.972,56$ & 1 & 4,17 \\
\hline Alto & Limite Inferior & $3.972,56$ & Limite Superior & $5.952,38$ & 2 & 8,33 \\
\hline
\end{tabular}

A categoria máxima de apresentação do evento foi 'baixo' e sua unidade de apresentação ' -1 '. Essas informações resultaram na seguinte codificação: baixo $=-1$, médio = 0 e alto $=1$. Fazendo o cálculo da freqüência relativa ponderada, chega-se a 0,7917.

$$
\text { frequênciarelativapanderada }=\frac{((-1) \times 87,50+0 \times 4,17+1 \times 8,33)}{100}=-0,7917
$$

O resultado reforça a tendência de baixo índice de produtividade de mão-de-obra.

Calculando-se o índice de produtividade de mão-de-obra pelo quociente entre número de beneficiários diretos e quantidade de colaboradores, exceto voluntários, foram obtidos, conforme apresentado na Tabela 31, os seguintes resultados:

Tabela 31 - Distribuição de freqüência do índice de produtividade de mão-de-obra utilizando o 'número de beneficiários diretos' e excluindo os voluntários

\begin{tabular}{|l|l|c|c|c|c|c|}
\hline Maior Valor & Menor Valor & Intervalo & $\mathbf{N}^{\mathbf{0}}$ de Classes & Amplitude & & \\
\hline \multicolumn{1}{|c|}{$8.005,73$} & 61,54 & $7.944,19$ & 3 & $2.648,06$ & & Qtde \\
\hline Intervalos & & & & & & 79,17 \\
\hline Baixo & Limite Inferior & 61,54 & Limite Superior & $2.709,60$ & 19 & 12,50 \\
\hline Médio & Limite Inferior & $2.709,60$ & Limite Superior & $5.357,67$ & 3 & 8,33 \\
\hline Alto & Limite Inferior & $5.357,67$ & Limite Superior & $8.005,73$ & 2 & \\
\hline
\end{tabular}

A categoria máxima de apresentação do evento foi 'baixo' e sua unidade de apresentação ' -1 '. Essas informações resultaram na seguinte codificação: baixo $=-1$, médio $=$ 0 e alto $=1$. Fazendo o cálculo da freqüência relativa ponderada, chega-se a 0,7084 .

$$
\text { frequênciacelativaponderada }=\frac{((-1) \times 79,17+0 \times 12,50+1 \times 8,33)}{100}=-0,7084
$$


O resultado indica tendência de baixo índice de produtividade de mão-de-obra, mesmo quando se utiliza o número de beneficiários diretos como medida de resultado e são excluídos os voluntários da quantidade de colaboradores.

O quarto índice analisado foi o índice de produtividade de capital, calculado pelo quociente entre receita total e despesa total. A Tabela 32 apresenta os resultados encontrados.

Tabela 32 - Distribuição de freqüência do índice de produtividade de capital

\begin{tabular}{|l|c|c|c|c|c|c|}
\hline Maior Valor & Menor Valor & Intervalo & $\mathbf{N}^{\mathbf{0}}$ de Classes & Amplitude & & \\
\hline \multicolumn{1}{|c|}{2,2063} & 0,6557 & 1,5506 & 3 & 0,5169 & & \\
\hline Intervalos & & & & & Qtde & \% \\
\hline Baixo & Limite Inferior & 0,6557 & Limite Superior & 1,1725 & 19 & 67,86 \\
\hline Médio & Limite Inferior & 1,1726 & Limite Superior & 1,6894 & 7 & 25,00 \\
\hline Alto & Limite Inferior & 1,6895 & Limite Superior & 2,2063 & 2 & 7,14 \\
\hline
\end{tabular}

A categoria máxima de apresentação do evento foi 'baixo' e sua unidade de apresentação ' -1 '. Essas informações resultaram na seguinte codificação: baixo $=-1$, médio $=$ 0 e alto $=1$. Fazendo o cálculo da freqüência relativa ponderada, chega-se a 0,6072.

$$
\text { frequênciarelativaponderada }=\frac{((-1) \times 67,86+0 \times 25+1 \times 7,14)}{100}=-0,6072
$$

O resultado indica tendência de baixo índice de produtividade de capital. Salienta-se que, não sendo as ONGs entidades com fins lucrativos, é natural que os recursos financeiros que possuem não sejam utilizados para gerar recursos financeiros adicionais (lucro). $\mathrm{Na}$ verdade, é de se esperar que o resultado para esse índice seja bem próximo de 1 , ou seja, que a maior parte dos recursos financeiros obtidos seja aplicada sem produzir adicionais. No entanto, essa expectativa não pode ser considerada válida para entidades cujos recursos provêm principalmente dos associados, da prestação de serviços ou de outras fontes próprias.

Calculando-se o índice de produtividade de capital pelo quociente entre número de beneficiários diretos e despesa total, obtiveram-se os resultados apresentados na Tabela 33. Nesse caso, somente foi possível a inclusão de 20 ONGs.

Tabela 33 - Distribuição de freqüência do índice de produtividade de capital utilizando o 'número de beneficiários diretos'

\begin{tabular}{|c|c|c|c|c|c|c|}
\hline Maior Valor & Menor Valor & Intervalo & $\mathrm{N}^{\circ}$ de Classes & Amplitude & & \\
\hline 0,3113 & 0,0009 & 0,3104 & 3 & 0,1035 & & \\
\hline Intervalos & & & & & Qtde & $\%$ \\
\hline Baixo & Limite Inferior & 0,0009 & Limite Superior & 0,1044 & 18 & 90,00 \\
\hline Médio & Limite Inferior & 0,1044 & Limite Superior & 0,2078 & 1 & 5,00 \\
\hline Alto & Limite Inferior & 0,2078 & Limite Superior & 0,3113 & 1 & 5,00 \\
\hline
\end{tabular}


Considerou-se que a categoria máxima de apresentação do evento foi 'baixo' e sua unidade de apresentação '-1'. Essas informações resultaram na seguinte codificação: baixo = 1 , médio $=0$ e alto $=1$. Fazendo o cálculo da freqüência relativa ponderada, chega-se a 0,8500 , resultado que confirma o encontrado anteriormente.

$$
\text { frequênciarelativaponderada }=\frac{((-1) \times 90+0 \times 5+1 \times 5)}{100}=-0,8500
$$

A análise qualitativa buscou identificar os fatores com os quais as ONGs pesquisadas estavam comprometidas na satisfação de seus beneficiários por meio da qualidade dos serviços prestados. Inicialmente, identificou-se a distribuição de freqüências, tendo por base as respostas obtidas durante a coleta de dados. Em seguida, utilizou-se o teste $\chi^{2}$ para examinar a existência ou não de discrepâncias entre freqüências observadas e esperadas. Vale lembrar que para cada ONG solicitou-se a indicação dos três principais fatores com os quais estavam comprometidas. Como 30 entidades responderam, o total de respostas foi 90 (30 x 3). Quatro entidades não forneceram respostas a esse item por não considerá-lo adequado a suas realidades. A Tabela 34 apresenta as freqüências observadas para cada fator de qualidade.

\section{Tabela 34 - Freqüências observadas dos fatores de qualidade indicados pelas ONGs pesquisadas}

\begin{tabular}{|l|c|}
\hline \multicolumn{1}{|c|}{ Fatores } & $\begin{array}{c}\text { Freqüência } \\
\text { observada }\end{array}$ \\
\hline Prestar serviços dentro de especificações/padrões estabelecidos & 14 \\
\hline Manter um relacionamento com polidez e respeito aos beneficiários & 26 \\
\hline Atender um maior número de beneficiários com o mesmo volume de recursos & 3 \\
\hline Identificar as necessidades dos beneficiários & 28 \\
\hline Ser ágil no tempo de resposta na prestação dos serviços & 6 \\
\hline Outros & 13 \\
\hline Total & $\mathbf{9 0}$ \\
\hline
\end{tabular}

Analisando-se as freqüências observadas, percebe-se que os dois fatores mais constantes são, pela ordem decrescente, 'identificar as necessidades dos usuários' e 'manter um relacionamento com polidez e respeito com os beneficiários'. O primeiro desses fatores foi indicado por um pouco mais que $93 \%$ das entidades e o comprometimento com ele permite às ONGs satisfazerem as necessidades dos beneficiários, ou seja, o conhecimento das necessidades dos beneficiários é fundamental na prestação de serviços. Esse fator representa o segundo nível de qualidade apresentado por Giffi et al (apud Moreira, 1996, p. 46), qual seja, qualidade de necessidade. O segundo fator mais indicado, 'manter um relacionamento com polidez e respeito com os beneficiários', foi apontado por um pouco mais que $86 \%$ das ONGs. 
Esse fator permite uma maior aproximação entre ONGs e beneficiários, o que vem facilitar o processo de identificação das necessidades desses últimos. O fator 'prestar serviços dentro das especificações/padrões estabelecidos', indicado por um pouco mais que $46 \%$ das entidades, apresenta freqüência mediana, quando comparado aos dois predominantes. Esse fator representa o primeiro nível de qualidade apresentado por Giffi et al (apud Moreira, 1996, p. 46), qual seja, qualidade de conformação. Atenção a esse fator permite que seja reduzido o número de serviços prestados de forma 'defeituosa'.

\subsection{Análise da Relação entre Estruturas Organizacionais e Indicadores de Desempenho}

Tendo-se conhecimento das estruturas organizacionais predominantes entre as ONGs pesquisadas, assim como o perfil dos indicadores de desempenho, quantitativa e qualitativamente, o presente tópico procurou identificar a existência de relação entre estruturas organizacionais e indicadores de desempenho. Excluiu-se a análise acerca da estrutura simples, pois apenas uma ONG se aproximou desse arranjo organizacional, tornando-se desnecessária a referida análise. A Tabela 35 mostra um primeiro relacionamento entre estruturas organizacionais e índice de aplicação dos recursos na atividade meio.

Tabela 35 - Relação entre estruturas organizacionais e índice de aplicação dos recursos na atividade meio

\begin{tabular}{|l|c|c|c|c|c|c|c|}
\hline \multirow{2}{*}{$\begin{array}{c}\text { Estruturas } \\
\text { Organizacionais }\end{array}$} & \multicolumn{6}{|c|}{ Índice de aplicação dos recursos na atividade meio } \\
\cline { 2 - 9 } & Baixo & $\mathbf{\%}$ & Médio & $\mathbf{\%}$ & Alto & $\boldsymbol{\%}$ & Total \\
\hline Burocracias Profissionais & 8 & 72,73 & 3 & 27,27 & 0 & 0 & $\mathbf{1 1}$ \\
\hline Adhocracias & 9 & 75,00 & 2 & 16,67 & 1 & 8,33 & $\mathbf{1 2}$ \\
\hline Missionárias & 1 & 25,00 & 2 & 50,00 & 1 & 25,00 & $\mathbf{4}$ \\
\hline Total & $\mathbf{1 8}$ & & $\mathbf{7}$ & & $\mathbf{2}$ & & $\mathbf{2 7}$ \\
\hline
\end{tabular}

Considerou-se a intensidade 'baixo' como a categoria máxima de apresentação do evento e sua unidade de apresentação ' 1 '. Essas informações resultaram na seguinte codificação: baixo $=1$, médio $=0$ e alto $=-1$. Calculou-se as freqüências ponderadas para cada tipo organizacional.

$$
\begin{aligned}
& \text { Burocracias Profissionais }=\frac{1 \times 72,73+0 \times 27,27+(-1) \times 0}{100}=0,7273 \\
& \text { Adhocracias }=\frac{1 \times 75+0 \times 16,67+(-1) \times 8,33}{100}=0,6667
\end{aligned}
$$


Misisonárias $=\frac{1 \times 25,00+0 \times 50,00+(-1) \times 25,00}{100}=0,0$

As ONGs com estruturas próximas de burocracias profissionais e de adhocracias apresentam baixo índice de aplicação de recursos na atividade meio, enquanto ONGs próximas de estruturas missionárias apresentam resultado mediano.

O segundo relacionamento foi entre tipos organizacionais e índice de aplicação dos recursos na atividade fim, conforme apresentado na Tabela 36.

Tabela 36 - Relação entre estruturas organizacionais e índice de aplicação dos recursos na atividade fim

\begin{tabular}{|l|c|c|c|c|c|c|c|}
\hline \multirow{2}{*}{$\begin{array}{c}\text { Estruturas } \\
\text { Organizacionais }\end{array}$} & \multicolumn{6}{|c|}{ Índice de aplicação dos recursos diretamente na prestaço serviços } \\
\cline { 2 - 8 } & Baixo & $\mathbf{\%}$ & Médio & $\mathbf{\%}$ & Alto & \% & Total \\
\hline Burocracias Profissionais & 1 & 9,09 & 3 & 27,27 & 7 & 63,64 & $\mathbf{1 1}$ \\
\hline Adhocracias & 1 & 8,33 & 3 & 25,00 & 8 & 66,67 & $\mathbf{1 2}$ \\
\hline Missionárias & 1 & 25,00 & 3 & 75,00 & 0 & 0 & $\mathbf{4}$ \\
\hline Total & $\mathbf{3}$ & & $\mathbf{9}$ & & $\mathbf{1 5}$ & & $\mathbf{2 7}$ \\
\hline
\end{tabular}

Considerou-se a intensidade 'baixo' como a categoria máxima de apresentação do evento e sua unidade de apresentação '1'. Essas informações resultaram na seguinte codificação: baixo $=1$, médio $=0$ e alto $=-1$. Calculou-se as freqüências ponderadas para cada tipo organizacional.

$$
\begin{aligned}
& \text { Burocracias Pr ofissionais }=\frac{1 \times 9,09+0 \times 27,27+(-1) \times 63,64}{100}=-0,5455 \\
& \text { Adhocracias }=\frac{1 \times 8,33+0 \times 25+(-1) \times 66,67}{100}=-0,5834 \\
& \text { Misisonárias }=\frac{1 \times 25+0 \times 75+(-1) \times 0}{100}=0,2500
\end{aligned}
$$

As ONGs próximas de burocracias profissionais e de adhocracias apresentam alto índice de aplicação dos recursos na atividade fim, enquanto ONGs próximas de estruturas missionárias apresentam resultado mediano para esse índice. Ou seja, os relacionamentos são inversos aos realizados anteriormente. Assim, ONGs próximas de burocracias profissionais e de adhocracias apresentam melhor desempenho em relação a esses dois índices quando comparadas com entidades próximas de estruturas missionárias. Comparando entre ONGs próximas de burocracia profissional e de adhocracia, percebe-se que as primeiras aplicam menos recursos na atividade meio enquanto as segundas, mais recursos na atividade fim. 
O terceiro relacionamento foi entre tipos organizacionais e produtividade de mão-deobra utilizando a receita total como medida do resultado, conforme apresentado na Tabela 37.

Tabela 37 - Relação entre estruturas organizacionais e produtividade de mão-de-obra

\begin{tabular}{|l|c|c|c|c|c|c|c|}
\hline \multirow{2}{*}{ Estruturas Organizacionais } & \multicolumn{7}{|c|}{ Produtividade de mão-de-obra } \\
\cline { 2 - 9 } & Baixo & $\mathbf{\%}$ & Médio & $\mathbf{\%}$ & Alto & $\mathbf{\%}$ & Total \\
\hline Burocracias Profissionais & 8 & 72,73 & 3 & 27,27 & 0 & 0 & $\mathbf{1 1}$ \\
\hline Adhocracias & 10 & 83,34 & 1 & 8,33 & 1 & 8,33 & $\mathbf{1 2}$ \\
\hline Missionárias & 3 & 75,00 & 1 & 25,00 & 0 & 0 & $\mathbf{4}$ \\
\hline Total & $\mathbf{2 2}$ & & $\mathbf{5}$ & & $\mathbf{1}$ & & $\mathbf{2 8}$ \\
\hline
\end{tabular}

Considerou-se a intensidade 'baixo' como a categoria máxima de apresentação do evento e sua unidade de apresentação ' 1 '. Essas informações resultaram na seguinte codificação: baixo $=1$, médio $=0$ e alto $=-1$. Calculou-se as freqüências ponderadas para cada tipo organizacional.

$$
\begin{aligned}
& \text { Burocracias Profissionais }=\frac{1 \times 72,73+0 \times 27,27+(-1) \times 0}{100}=0,7273 \\
& \text { Adhocracias }=\frac{1 \times 83,34+0 \times 8,33+(-1) \times 8,33}{100}=0,7501 \\
& \text { Misisonárias }=\frac{1 \times 75+0 \times 25+(-1) \times 0}{100}=0,7500
\end{aligned}
$$

As ONGs investigadas apresentam baixa produtividade de mão-de-obra, destacando-se as próximas de burocracias profissionais por apresentarem melhor desempenho quando os três tipos organizacionais são comparados, enquanto entidades próximas de adhocracias e organizações missionárias apresentam praticamente desempenho igual para esse indicador.

O quarto relacionamento foi entre tipos organizacionais e produtividade de capital, conforme apresentado na Tabela 38.

Tabela 38 - Relação entre estruturas organizacionais e produtividade de capital

\begin{tabular}{|l|c|c|c|c|c|c|c|}
\hline \multirow{2}{*}{ Estruturas Organizacionais } & \multicolumn{7}{c|}{ RTot/Dtot } \\
\cline { 2 - 9 } & Baixo & $\mathbf{\%}$ & Médio & $\mathbf{\%}$ & Alto & $\boldsymbol{\%}$ & Total \\
\hline Burocracias Profissionais & 5 & 45,45 & 5 & 45,45 & 1 & 9,10 & $\mathbf{1 1}$ \\
\hline Adhocracias & 11 & 91,67 & 1 & 8,33 & 0 & 0 & $\mathbf{1 2}$ \\
\hline Missionárias & 2 & 50,00 & 1 & 25,00 & 1 & 25,00 & $\mathbf{4}$ \\
\hline Total & $\mathbf{1 9}$ & & $\mathbf{7}$ & & $\mathbf{2}$ & & $\mathbf{2 8}$ \\
\hline
\end{tabular}


A intensidade 'baixo' como a categoria máxima de apresentação do evento e sua unidade de apresentação ' 1 '. Essas informações resultam na seguinte codificação: baixo = 1 , médio $=0$ e alto $=-1$. Calculou-se as freqüências ponderadas para cada tipo organizacional.

$$
\begin{aligned}
& \text { Burocracias Profissionais }=\frac{1 \times 45,45+0 \times 45,45+(-1) \times 9,10}{100}=0,3635 \\
& \text { Adhocracias }=\frac{1 \times 91,67+0 \times 8,33+(-1) \times 0}{100}=0,9167 \\
& \text { Misisonárias }=\frac{1 \times 50+0 \times 25+(-1) \times 25}{100}=0,2500
\end{aligned}
$$

Praticamente todas as ONGs apresentam baixa produtividade de capital, com exceção daquelas próximas a estruturas missionárias com resultado mediano para esse índice. O pior desempenho é registrado pelas ONGs próximas de adhocracias.

A Tabela 39, por sua vez, relacionou estruturas organizacionais e fatores de qualidade.

Tabela 39 - Relação entre estruturas organizacionais e fatores de qualidade

\begin{tabular}{|l|c|c|c|}
\hline \multicolumn{1}{|c|}{ Fatores } & $\begin{array}{c}\text { Burocracia } \\
\text { Profissional }\end{array}$ & $\begin{array}{c}\text { Adho- } \\
\text { cracia }\end{array}$ & $\begin{array}{c}\text { Missio- } \\
\text { nária }\end{array}$ \\
\hline Prestar serviços dentro de especificações/padrões estabelecidos & 5 & 5 & 4 \\
\hline Manter um relacionamento com polidez e respeito aos beneficiários & 12 & 8 & 6 \\
\hline Atender um maior número de beneficiários com o mesmo volume de recursos & 2 & 0 & 1 \\
\hline Identificar as necessidades dos beneficiários & 12 & 11 & 5 \\
\hline Ser ágil no tempo de resposta na prestação dos serviços & 3 & 3 & 0 \\
\hline Outros & 5 & 6 & 2 \\
\hline
\end{tabular}

Os dois fatores predominantes entre entidades próximas de burocracias profissionais são: 'manter um relacionamento com polidez e respeito aos beneficiários' e 'identificar as necessidades dos usuários'. Esse último é um dos três fatores de qualidade identificados por Giffi (apud Moreira, 1996, p. 46). Em entidades próximas de adhocracias predomina o fator 'identificar as necessidades dos usuários', seguido do fator 'manter um relacionamento com polidez e respeito aos beneficiários'. As organizações missionárias, por sua vez, apresentam como seus principais fatores 'manter um relacionamento com polidez e respeito aos beneficiários' e 'identificar as necessidades dos usuários'. 


\section{CONCLUSÕES E SUGESTÕES}

Esta pesquisa tem por objetivo principal identificar e analisar relações entre aspectos básicos determinantes das estruturas organizacionais e indicadores de desempenho operacional das ONGs do Estado de São Paulo. Para tanto, considerou três etapas para que esse objetivo pudesse ser alcançado, cada qual relacionada com pelo menos um objetivo secundário.

A primeira etapa procurou identificar os aspectos básicos determinantes das estruturas organizacionais presentes nessas entidades, em outras palavras, buscou indicar os parâmetros de design e os fatores situacionais que determinam os tipos organizacionais predominantes. Os resultados apontam que as ONGs investigadas apresentam como principais parâmetros os seguintes: muita utilização de instrumentos de interligação, pouca especialização vertical das tarefas, muito treinamento, muita doutrinação e muito planejamento das ações. Ademais, apresentam um controle de desempenho com propensão para muito e um agrupamento essencialmente por projetos. Por outro lado, os parâmetros especialização horizontal das tarefas e formalização do comportamento não são significativos. Por fim, a tomada de decisão é descentralizada verticalmente e centralizada horizontalmente, ou seja, a cúpula estratégica divide parte do poder de tomada de decisão com o núcleo operacional, enquanto a assessoria de apoio e a tecnoestrutura compartilham pouco desse poder, especialmente essa última.

Os fatores situacionais demonstram que o ambiente no qual essas entidades atuam não é estável nem dinâmico, é complexo, é integrado e não é hostil tampouco magnânimo. Ademais, há predominância de ONGs pequenas e jovens sobre as quais é exercido constante controle externo tanto de agências de cooperação internacional, quanto de entidades do Governo, principalmente por meio da solicitação da prestação de contas e da apresentação de relatórios detalhando as atividades realizadas com os recursos financeiros fornecidos. Por fim, o sistema técnico predominante é simples e não regulado, já que são os próprios membros da entidade quem presta os serviços com pouco ou nenhum uso de equipamentos sofisticados.

Considerando esses aspectos básicos, constata-se que três tipos organizacionais, considerando a tipologia original de Mintzberg (2001; 2003), destacam-se, a saber: adhocracias, burocracias profissionais e estruturas missionárias. Sendo pequena a diferença entre as médias de aderência conceitual desses três arranjos organizacionais, não se pode afirmar que exista um predominante, ou seja, existem entre as ONGs pesquisadas três tipos organizacionais predominantes. 
Analisando individualmente, constata-se que $44,11 \%$ das ONGs pesquisadas se aproximam de burocracias profissionais, 38,24\% de adhocracias, $14,71 \%$ de estruturas missionárias e 2,94\% de estruturas simples. O fator preponderante na determinação das estruturas organizacionais dessas entidades foi a consistência entre os parâmetros de design e os fatores situacionais (50\%), enquanto $38,24 \%$ das ONGs investigadas determinam suas estruturas com base na ideologia presente na entidade.

Com base na tipologia original de Mintzberg (2001, 2003) não é possível asseverar que as entidades investigadas apresentam estruturas organizacionais puras. $\mathrm{O}$ fato de se ter encontrado mais de um tipo organizacional predominante entre as ONGs objeto do estudo e também de não se ter observado, na análise das estruturas organizacionais predominantes em cada ONG, aspectos básicos de apenas um tipo organizacional - havendo casos em que uma mesma entidade apresentou três arranjos organizacionais com igual aderência conceitual -, fundamentam essa afirmação. O próprio Mintzberg (2001, 2003) afirma que estruturas organizacionais puras são configurações ideais, não sendo comum, na prática, serem encontradas. Ao contrário, o que se encontram, são configurações híbridas, ou seja, estruturas organizacionais com características de mais de um tipo organizacional.

Dessa forma, duas possíveis conjeturas podem ser elaboradas: a primeira afirma que as ONGs investigadas apresentam estruturas organizacionais híbridas, envolvendo aspectos básicos presentes em burocracias profissionais, adhocracias e estruturas missionárias; a segunda defende que essas entidades estão passando de um tipo organizacional para outro, ou seja, à medida que se capacitam saem de estruturas missionárias em direção a burocracias profissionais - caso venham atuar em ambientes estáveis e complexos - ou a adhocracias caso venham atuar em ambientes dinâmicos e complexos, dentre outras possíveis variáveis.

No entanto, se for considerada a hipótese da criação que, conforme Mintzberg (2003, p. 327), permite que uma combinação original entre parâmetros de design e fatores situacionais seja elaborada de forma consistente, pode-se elaborar uma terceira conjetura, qual seja, as ONGs investigadas apresentam um tipo organizacional que lhes é específico e que não consta da tipologia original desse autor. Esse tipo apresenta como principais aspectos básicos os seguintes: utilização de muitos instrumentos de interligação, pouca formalização do comportamento, muito treinamento, muita doutrinação, muito planejamento das ações, propensão para muito controle de desempenho, descentralização vertical, agrupamento por mercado, entidades jovens e pequenas, ambiente nem estável nem dinâmico e ao mesmo tempo complexo com constante controle externo. Essa conjetura é tanto mais verdadeira 
quando se considera que o fator predominante na configuração das estruturas organizacionais dessas entidades foi a consistência entre parâmetros de design e fatores situacionais.

A segunda etapa consiste na mensuração dos indicadores de desempenho para o qual foram consideradas duas dimensões, uma quantitativa e outra qualitativa. A primeira envolveu quatro índices: dois índices de aplicação de recursos e dois índices de produtividade. Os índices de produtividade foram calculados tanto considerando a receita total como medida de resultado quanto o número de beneficiários diretos. Ademais, no cálculo da produtividade de mão-de-obra foram considerados tanto o número total de colaboradores quanto esse número reduzido da quantidade de voluntários. A dimensão qualitativa buscou identificar os fatores com os quais as ONGs pesquisadas estavam comprometidas no sentido de satisfazer seus beneficiários por meio da qualidade dos serviços.

Constatou-se que a maior parte das ONGs pesquisadas aplica seus recursos financeiros preferencialmente na prestação de serviços ou no desenvolvimento de seus projetos, considerando a metodologia utilizada. Tal aspecto demonstra coerência principalmente quando se considera que os recursos financeiros obtidos por essas entidades estão voltados justamente para atividades fins, com poucos casos em que os financiamentos são destinados para manutenção operacional.

Verificou-se que $78,57 \%$ das ONGs pesquisadas apresentam baixa produtividade de mão-de-obra calculada pelo quociente entre receita total e quantidade de colaboradores. Quando se retirou a quantidade de voluntários do total de colaboradores para o cálculo desse índice, constatou-se que $67,86 \%$ dessas entidades apresentam baixa produtividade de mão-deobra. Esses resultados demonstram que essas entidades utilizam poucos voluntários em suas atividades, haja vista a pequena mudança no índice. Geralmente esses voluntários atuam na diretoria ou no conselho fiscal. Ademais, é preciso considerar que o volume de recursos obtidos por uma entidade sem fins lucrativos, conforme constatado por Frumkim \& Kim (2000), não parece ser determinado pela eficiência organizacional, de forma que pode não haver uma relação de dependência entre quantidade de colaboradores e receita total.

Observou-se que $87,5 \%$ das ONGs investigadas apresentam baixa produtividade de mão-de-obra calculada pelo quociente entre número de beneficiários diretos e quantidade de colaboradores. Ou seja, calculada dentro dessa metodologia, a produtividade de mão-de-obra se apresentava ainda mais baixa. Quando se retirou a quantidade de voluntários do total de colaboradores para o cálculo desse índice, constatou-se que 79,17\% das entidades pesquisadas apresentam baixa produtividade de mão-de-obra. Além do comentário já feito acerca do número inexpressivo de voluntários, é preciso considerar que uma parte significativa das 
ONGs pesquisadas atua na capacitação, gerando o processo por elas denominado de multiplicação, sendo difícil dimensionar seus efeitos. Outrossim, aumentar o número de beneficiários não está entre as prioridades dessas entidades.

Verificou-se que 67,86\% das ONGs investigadas apresentam baixa produtividade de capital quando calculado pelo quociente entre receita total e despesa total. Além disso, considerando-se a ressalva já realizada acerca do volume de recursos como medida de resultado, um outro ponto merece atenção. Em entidades com fins lucrativos é de se esperar que exista um diferencial - denominado de lucro - entre os recursos aplicados em um período e os recursos obtidos nesse mesmo período; em entidades sem fins lucrativos, por sua vez, essa expectativa não existe, o que se espera, na verdade, é que os recursos financeiros disponibilizados sejam completamente aplicados em suas atividades, ou seja, espera-se que o resultado para esse índice seja o mais próximo possível de 1. Exceções são as entidades cujos recursos financeiros provêm principalmente de associados, da prestação de serviços ou de outras fontes próprias, situações nas quais essa expectativa se reduz.

Observou-se que 90\% das ONGs pesquisadas apresentam baixa produtividade de capital quando calculado pelo quociente entre número de beneficiários diretos e despesa total. As ressalvas relacionadas ao uso dos beneficiários diretos são igualmente válidas aqui.

A análise dos fatores de qualidade predominantes evidencia que mais de $90 \%$ das entidades investigadas indicam o fator 'identificar as necessidades dos usuários', mais de 85\% indicam o fator 'manter um relacionamento com polidez e respeito aos beneficiários' e mais de 45\% o fator 'prestar serviços dentro das especificações/padrões estabelecidos'. O primeiro e o último fatores estão entre os três níveis de qualidade apresentados por Giffi et al (apud Moreira, 1996, p. 46) como os reconhecíveis atualmente. O segundo fator permite maior aproximação entre ONGs e beneficiários, o que pode facilitar o processo de identificação das necessidades desses últimos. $\mathrm{O}$ fator - 'atender um maior número de beneficiários com o mesmo volume de recursos' - é o que aparece com menor freqüência.

A terceira etapa consiste na identificação de como se comporta o relacionamento entre tipos organizacionais e indicadores de desempenho. De forma subjacente, analisa-se o comportamento da relação entre estruturas organizacionais e área de atuação, idade, tamanho e composição das receitas.

Iniciando-se pelo relacionamento entre estruturas organizacionais e área de atuação, constata-se que 50\% das ONGs que se aproximam de burocracias profissionais atuam na área de educação/pesquisa, enquanto que $43 \%$ na área de discriminação racial e de gênero, ressaltando-se que nenhuma entidade próxima a esse tipo organizacional atua na área de 
defesa de direitos. Verifica-se que $38 \%$ das entidades que se aproximam de adhocracias operam na defesa de direitos, enquanto que 31\% na área sócio-ambiental. As demais entidades próximas a esse tipo organizacional estão igualmente divididas entre as duas outras áreas de atuação. Observa-se que 50\% das entidades que se aproximam de estruturas missionárias atuam na área de defesa de direitos, estando as demais ONGs próximas a esse tipo organizacional igualmente divididas entre as outras três áreas de atuação. Por fim, a entidade próxima da estrutura simples atua na defesa de direitos.

O relacionamento entre estruturas organizacionais e idade e tamanho demonstra que a maior parte das entidades investigadas, independentemente do tipo organizacional predominante, está associada a estruturas jovens e/ou pequenas. Esses resultados confirmam a teoria de Mintzberg $(2001,2003)$ para quem estruturas missionárias e simples são tipicamente jovens e pequenas, adhocracias são tipicamente jovens e podem assumir tamanhos variados e burocracias profissionais podem assumir idade e tamanho variados. Em conjunto, constata-se que $58,82 \%$ das ONGs investigadas são jovens e pequenas - sete próximas de burocracias profissionais, oito de adhocracias, quatro de estruturas missionárias e uma de estruturas simples - e que nenhuma é grande e antiga.

O relacionamento entre tipos organizacionais e composição das receitas evidencia que $69 \%$ dos recursos financeiros obtidos por ONGs próximas de burocracias profissionais são provenientes de agências de cooperação internacional, enquanto que entidades do Governo fornecem 16\% desses recursos. Para entidades que se aproximam de adhocracias, ainda que $40 \%$ de seus recursos financeiros sejam procedentes de agências de cooperação internacional, apresentam maior diversificação quando comparadas com as demais. Para entidades que se aproximam de estruturas missionárias, a maior parte de seus recursos são fornecidos por entidades do Governo. Por fim, entidades próximas de estruturas simples obtêm $73 \%$ de seus recursos financeiros da prestação de serviços e o restante de doações individuais.

Partindo para a análise entre tipos organizacionais e indicadores de desempenho, constata-se que entidades próximas de burocracias profissionais apresentam melhores indicadores de aplicação dos recursos na atividade meio e melhores indicadores de produtividade de mão-de-obra. Em nenhum índice calculado, entidades dessa natureza exibem piores indicadores de desempenho.

Entidades próximas de adhocracias demonstram melhores índices de aplicação dos recursos na atividade fim. Por outro lado, apresentam piores indicadores de produtividade de mão-de-obra e de produtividade de capital. 
ONGs próximas de estruturas missionárias exibem melhores índices de produtividade de capital. Em nenhum índice calculado, entidades dessa natureza apresentam piores indicadores de desempenho.

Uma única entidade próxima da estrutura simples aplica todos seus recursos financeiros na atividade meio.

Dessa forma, os resultados sugerem que entidades que se aproximam de burocracias profissionais, de maneira geral, estão relacionadas com melhores indicadores de desempenho, enquanto que aquelas próximas de estruturas missionárias vêm em seguida. ONGs próximas de adhocracias exibem os piores indicadores de desempenho.

A relação entre estruturas organizacionais e fatores de qualidade demonstra que - para os três tipos organizacionais - os três principais fatores foram 'manter um relacionamento com polidez e respeito aos beneficiários', 'identificar as necessidades dos usuários' e 'prestar serviços dentro de especificações/padrões estabelecidos'.

Os resultados, portanto, sugerem que não existe uma estrutura organizacional dentro da tipologia original de Mintzberg $(2001 ; 2003)$ que seja predominante, havendo, na verdade, três tipos organizacionais que se destacam. Desses três, as ONGs que se aproximam de burocracias profissionais são as que apresentam melhores índices de desempenho, enquanto que aquelas próximas de adhocracias apresentam os piores resultados, considerando todos os indicadores de desempenho adotados e as ONGs pesquisadas.

Também não foram verificadas estruturas puras, ou seja, as ONGs pesquisadas analisadas individualmente - apresentaram parâmetros de design e fatores situacionais de mais que um tipo organizacional. Dessa forma, a hipótese dessa pesquisa - quanto mais uma ONG se aproxima de uma estrutura organizacional missionária, melhor tende a ser os seus indicadores de desempenho operacional - não foi confirmada.

Considerando-se que as contribuições foram atingidas e os objetivos alcançados, algumas sugestões para futuras pesquisas podem ser registradas. Primeiro, pesquisas longitudinais permitiriam identificar qual das conjeturas acerca das estruturas organizacionais predominantes nessas entidades seria corroborada, se a da estrutura híbrida, a da transição estrutural, ou a da hipótese de criação. Pesquisas dessa natureza também permitiriam uma melhor análise dos índices de desempenho utilizados nessa pesquisa e, ainda, possibilitariam a identificação de referenciais de excelência - benchmarking - para os indicadores de desempenho, considerando a área de atuação, o tamanho, a idade, dentre outros. Sugere-se que outras variáveis sejam relacionadas com estruturas organizacionais como, por exemplo, o sistema de informações gerenciais; assim como, a análise do efeito que outras variáveis 
possam ter sobre o desempenho de ONGs, como o nível de envolvimento da diretoria e o perfil de seus membros. Outra possibilidade é que sejam comparadas as estruturas organizacionais de ONGs cujos recursos financeiros são provenientes principalmente de agências de cooperação internacional com as estruturas organizacionais dessas entidades. Recomenda-se também comparar estruturas organizacionais de ONGs de alto e de baixo desempenho com o objetivo de verificar as semelhanças e diferenças existentes. Por fim, indica-se a comparação entre as entidades que atuam nos três setores econômicos de forma a identificar se existem diferenças significativas em seus desenhos organizacionais, assim como, se existem significativas diferenças relativas ao desempenho de tais organizações. 


\section{BIBLIOGRAFIA}

ARANTES, P. E. Esquerda e direita no espelho das ONGs. In: Cadernos ABONG. ONGs: identidades e desafios atuais. n. 27, maio 2000. Campinas: Autores Associados, 2000. p. 327.

ASSOCIAÇÃO BRASILEIRA DE NORMAS TÉCNICAS. NBR 10520: informação e documentação - apresentação de citações em documentos. Rio de Janeiro, 2001.

. NBR 14724: informação e documentação - trabalhos acadêmicos - apresentação. Rio de Janeiro, 2001. 2000.

. NBR 6023: informação e documentação - referências - elaboração. Rio de Janeiro,

. NBR 6028: Resumos. Rio de Janeiro, 1990.

. NBR 10523. Entrada para nomes de língua portuguesa em registros bibliográficos. Rio de Janeiro, 1988.

ASSOCIAÇÃO BRASILEIRA DE ORGANIZAÇÕES NÃO-GOVERNAMENTAIS. Associadas. Disponível em: <http://www.abong.org.br>.

; ADMINISTRAÇÃO E FINANÇAS PARA O DESENVOLVIMENTO

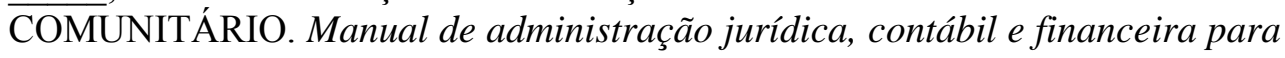
organizações não-governamentais. São Paulo: Peirópolis, 2003.

. Manual de fundos públicos: controle social e acesso aos recursos públicos. São Paulo: ABONG/Peirópolos, 2002a. Série Desenvolvimento Institucional.

. ONGs no Brasil: perfil e catálogo das associadas à ABONG. São Paulo: ABONG, 2002b. Série Desenvolvimento Institucional.

. Carta de princípios e estatuto. São Paulo: ABONG, 2000.

ASSOCIAÇÃO NACIONAL DE PÓS-GRADUAÇÃO E PESQUISA EM ADMINISTRAÇÃO. Encontro Nacional da ANPAD. Disponível em:

$<$ http://www.anpad.org.br>. Acesso em: 22 out. 2003.

BAILEY, M. Levantamento de fundos no Brasil: principais implicações para as Organizações da Sociedade Civil e ONGs internacionais. In: Cadernos ABONG. ONGs: identidades e desafios atuais. n. 27, maio 2000. Campinas: Autores Associados, 2000. p. 87-106.

BANKER, R. D. et al. An empirical investigation of an incentive plan that includes nonfinancial performance measures. The Accounting Review. v. 75, n. 1, jan 2000. p. 65-92.

BARBOSA, M. N. L.; OLIVEIRA, C. F. Manual de ONGs: guia prático de orientação jurídica. 3. ed. atual. Rio de Janeiro: Editora FGV, 2002.

BATEMAN, T. S.; SNELL, S. A. Administração: construindo vantagem competitiva. São Paulo: Atlas, 1998.

BAVA, S. C. ONGs republicanas e democráticas em um novo cenário político. In: ASSOCIAÇÃO BRASILEIRA DE ORGANIZAÇÕES NÃO-GOVERNAMENTAIS. Governo e sociedade civil: um debate sobre espaços públicos democráticos. São Paulo: Peirópolis, 2003. p. 53-61.

. O terceiro setor e os desafios de São Paulo para o Século XXI. In: Cadernos ABONG.

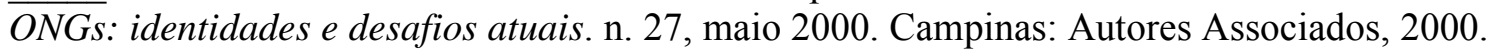
p. 41-86. 
BERNARDES, C.; MARCONDES, R. C. Teoria geral da administração: gerenciando organizações. 3 ed. rev. ampl. São Paulo: Saraiva, 2003.

. Sociologia aplicada à administração. 5 ed. São Paulo: Saraiva, 2000.

BLAU, P. M.; SCOTT, W. R. Organizações formais: uma abordagem comparativa. São Paulo: Atlas, 1970.

BLICKENDORFER, R.; JANEY, J. Measuring performance: nonprofit organization performance meet. Nonprofit world. v. 6, n. 2, Mar/Apr 1988. p. 18-22. Disponível em: <www.umi.com/proquest>. Acesso em: 27 ago. 2003.

BONAVIDES, P. Formas de Estado e Governo. In: SCHIERA, P. et al. Curso de introdução à ciência política: o Estado e formas de Estado e Governo. Brasília: UNB, 1982. p. 45-76. Unidade III.

BRADLEY, B. et al. A oportunidade de US\$ 100 bilhões do terceiro setor. Harvard Business Review. V. 81, n. 5, maio 2003. p. 74-84.

BRASIL. Novo Código Civil Brasileiro. Lei $n^{o}$ 10.406, de 10 de janeiro de 2002. São Paulo: Escala, 2002.

. Constituição (1988). Constituição da República Federativa do Brasil. Brasília, DF: Senado, 1988.

. Plano Diretor da Reforma do Aparelho do Estado. Brasília, 1995. Disponível em: $<$ www.planalto.gov.br>. Acesso em: 07 out 2003.

Decreto-Lei $n^{o} 200$, de 25 de fevereiro de 1967. Dispõe sobre a organização da Administração Federal, estabelece diretrizes para a Reforma Administrativa e dá outras providências.

. Código Tributário Nacional. Lei $n^{o}$ 5.172, de 25 de outubro de 1966. São Paulo: Saraiva, 1989.

CAMARGO, M. F. et al. Gestão do Terceiro Setor no Brasil. São Paulo: Futura, 2001.

CARDOSO, F. H. Reforma do estado. In: PEREIRA, L. C. B.; SPINK, P. (orgs.). Reforma do estado e administração pública gerencial. 3 ed. Rio de Janeiro: Editora FGV, 1999. p. 15-19.

CARVALHO, C. A. P. Preservar a identidade e buscar padrões de eficiência: questões complementares ou contraditórias na atualidade das organizações não governamentais? Encontro Nacional da Associação Nacional dos Programas de Pós-Graduação em Administração, XXIII. Anais...Foz do Iguaçu, 1999.

CHIAVENATO, I. Teoria geral da administração. 3 ed. São Paulo: McGraw-Hill, 1986. v. 1. COELHO, S. C. T. Terceiro setor. Um estudo comparativo 'entre Brasil e Estados Unidos. São Paulo: SENAC, 2000.

COHEN, M. D. et al. A garbage can model of organizational model. Administrative Science Quaterly. v. 17, n. 1, mar 1972. p. 1-25.

CRUZ, C.; ESTRAVIZ, M. Captação de diferentes recursos para organizações da sociedade civil. Disponível em: <http://www.rits.org.br>. Acesso em: 30 abr 2003.

DALLARI, D. A. Elementos de teoria geral do Estado. 23 ed. São Paulo: Saraiva, 2002.

DI PIETRO, M. S. Parcerias na administração pública: concessão, permissão, franquia, terceirização e outras formas. 4 ed. São Paulo: Atlas, 2002. 
DINIZ, J. H. A. S.; MATTOS, P. L. C. L. Organizações não governamentais e gestão estratégica: desfiguração de seu caráter institucional-original? Encontro Nacional da Associação Nacional dos Programas de Pós-Graduação em Administração, XXVI. Anais... Salvador, 2002.

DRUCKER, P. F. Administração de organizações sem fins lucrativos. Princípios e práticas. 3 ed. São Paulo: Pioneira, 1994.

ETZIONI, A. Organizações modernas. 5 ed. São Paulo: Pioneira, 1976.

EXAME MELHORES E MAIORES. São Paulo: Abril, 2002. Anual.

FALCONER, A. P. A promessa do terceiro setor. Dissertação de Mestrado. FEA/USP. São Paulo, 1999.

FERNANDES, R. C. Privado porém público: o terceiro setor na América Latina. 3 ed. Rio de Janeiro: Relume-Dumará, 2002.

. O que é o Terceiro Setor. In: IOSCHPE, E. B. (org.). $3^{\circ}$ Setor: desenvolvimento social sustentado. 2 ed. Rio de Janeiro: Paz e Terra, 2000. p. 25-33.

FERRARI, A. T. Metodologia da pesquisa científica. São Paulo: MacGraw-Hill, 1982.

FISCHER, R. M. O desafio da colaboração: práticas de responsabilidade social entre empresas e terceiro setor. São Paulo: Gente, 2002.

.; FALCONER, A. P. Desafios da parceria governo e terceiro setor. Revista de Administração. v. 33, n. 1, jan/mar 1998. p. 12-19.

.; FISCHER, A. L. O dilema das ONG's. Encontro Nacional da Associação Nacional dos Programas de Pós-Graduação em Administração, XVIII. Anais... v. 10, Recursos Humanos. Curitiba, 1994. p. 17-25.

FONSECA, L. V. O estado, o terceiro setor e o mercado. Uma tríade complexa. Goiás: CFC, XVI Congresso Brasileiro de Contabilidade, 2000.

FORBES, D. P. Measuring the unmeasurable: empirical studies of nonprofit orgaization effectiveness from 1977 to 1997. Nonprofit and Voluntary Sector Quaterly. v. 27, n. 2, jun. 1998. p. 183-202. Disponível em: <www.umi.com/proquest>. Acesso em: 29 out. 2003.

FRUMKIN, P.; KIM, M. T. Strategic positioning and the finacing of nonprofit organizations: is efficiency rewarded in the contributions marketplace? The Hauser Center for Nonprofit Organizations. Oct 2000. Disponível em: <www.ssrn.com>. Acesso em: 21 jul. 2003.

GALER, D.; HOLLIDAY, A. Achieving quality in nonprofits. Nonprofit World. v. 6, n. 3, May/Jun 1988. p. 22-24. Disponível em: <www.umi.com/proquest>. Acesso em: 12 set. 2003.

GARVIN, D. A. Competing the eight dimensions of quality. Harvard Business Review. n. 6, nov./dec. 1987. p. 101-109.

GEORGE Jr., C. S. História do pensamento administrativo. São Paulo: Cultrix, 1974.

GIBSON, J. L. et al. Organizações: comportamento, estrutura e processos. São Paulo: Atlas, 1988.

GIDDENS, A. A terceira via e seus críticos. Rio de Janeiro: Record, 2001b.

. A terceira via: reflexões sobre o impasse político atual e o futuro da socialdemocracia. 4 ed. Rio de Janeiro: Record, 2001a.

GIL, A. C. Como elaborar projetos de pesquisa. 4 ed. São Paulo: Atlas, 2002. 
GLADE, W. A complementaridade entre a reestruturação econômica e a reconstrução do estado na América Latina. In: PEREIRA, L. C. B.; SPINK, P. (orgs.). Reforma do estado e administração pública gerencial. 3 ed. Rio de Janeiro: Editora FGV, 1999. p. 123-140.

GOODE, W. J.; HATT, P. K. Métodos em pesquisa social. 4 ed. São Paulo: Nacional, 1972.

GUIMARÃES, M. C. L. et al. Indicadores para Avaliar a Capacidade de Gestão de Organizações Sociais: resultados de um estudo piloto. Encontro Nacional da Associação Nacional dos Programas de Pós-Graduação em Administração, XXVII. Anais... Atibaia, 2003.

HAIR Jr., J. F. et al. Multivariate data analysis. 5 ed. New Jersey: Prentice Hall, 1998.

HALL, P. D. Inventing the nonprofit sector and other essays on philanthropy, voluntarism, and nonprofit organizations. Baltimore: The Johns Hopkins University Press, 1992.

HALL, R. H. Organizações: estrutura e processos. 3 ed. São Paulo: Prentice Hall, 1984.

HARDY, C.; FACHIN, R. Gestão estratégica na universidade brasileira: teoria e casos. 2 ed. Porto Alegre: Editora da UFRGS, 2000.

HERMAN, R. D.; RENZ, D. O. Theses on nonprofit organizational effectiveness. Nonprofit and Voluntary Sector Quarterly. V. 28, n. 2, jun 1999. p. 107-126.

HOBSBAWM, E. Era dos extremos: o breve século XX - 1914-1991. 2 ed. 8 reimpressão. São Paulo: Companhia das Letras, 1995.

HUDSON, M. Administrando organizações do terceiro setor. São Paulo: Makron Books, 1999.

INSTITUTO BRASILEIRO DE GEOGRAFIA E ESTATÍSTICA. Tabelas setoriais IBGE. Disponível em: <http://www.ibge.gov.br>. Acesso em: 18 nov. 2003.

IOSCHPE, E. B. (org.). $3^{o}$ Setor: desenvolvimento social sustentado. 2 ed. Rio de Janeiro: Paz e Terra, 2000.

KAPLAN, R. S.; NORTON, D. P. The balanced scorecard: measures that drive performance. Harvard Business Review. Jan./feb. 1992. p. 71-79.

KETTL, D. F. A revolução global: reforma da administração do setor público. In: PEREIRA, L. C. B.; SPINK, P. (orgs.). Reforma do estado e administração pública gerencial. 3 ed. Rio de Janeiro: Editora FGV, 1999. p. 75-121.

KHANDWALLA, P. N. Mass output orientatation of operations technology and organizational structure. Administrative Science Quaterly. v. 19, n. 1, mar. 1974. pg. 74-97.

KISIL, M. Organização social e desenvolvimento sustentável: projetos de base comunitária. In: IOSCHPE, E. B. (org.). $3^{o}$ Setor: desenvolvimento social sustentado. 2 ed. Rio de Janeiro: Paz e Terra, 2000. p. 131-155.

KRUGLIANSKAS, I. Estruturação organizacional e desempenho: estudo de casos em ONGs focadas na problemática socioambiental. Dissertação de Mestrado. FEA/USP. São Paulo, 2003.

LANDIM, L. Defining the nonprofit sector in developing societies: Brazil. In: SALAMON, L. M.; ANHEIER, H. K. Defining the nonprofit sector: a cross-national analysis. Manchester: Manchester University Press, 1997. pg. 323-349. 
A invenção das ONGs: do serviço invisível à profissão impossível. Tese de Doutorado. UFRJ. Rio de Janeiro, 1993. Disponível em: <http://www.rits.org.br>. Acesso em: 8 dez. 2003.

MACHADO-DA-SILVA, C. L.; FONSECA, V. S. Arranjo formal em organizações: uma análise do setor calçadista de Novo Hamburgo - RS. Encontro Nacional da Associação Nacional dos Programas de Pós-Graduação em Administração, XVIII. Anais... Curitiba, 1994.

MARÇON, D.; ESCRIVÃO FILHO, E. Gestão das organizações do Terceiro Setor: um repensar sobre as teorias organizacionais. Encontro Nacional da Associação Nacional dos Programas de Pós-Graduação em Administração, XXV. Anais... Campinas, 2001.

MARCONI, M. A.; LAKATOS, E. M. Metodologia científica. 3 ed. São Paulo: Atlas, 2000.

.; _ Fundamentos de metodologia científica. São Paulo: Atlas, 1985.

MARCOVITCH, J. Da exclusão à coesão social: profisssionalização do Terceiro Setor. In:

IOSCHPE, E. B. (org.). $3^{o}$ Setor: desenvolvimento social sustentado. 2 ed. Rio de Janeiro: Paz e Terra, 2000.

MARTINS, G. A; PAULI, S. Manual do mestrando e do doutorando da FEA. São Paulo, 2003. Disponível em: <www.eac.fea.usp.br/eac/pos>. Acesso em: 05 abr. 2004. $2002 \mathrm{a}$.

Manual para elaboração de monografias e dissertações. 3 ed. São Paulo: Atlas,

Estatística geral e aplicada. 2 ed. São Paulo: Atlas, 2002b.

MAXIMIANO, A. C. A. Introdução à administração. 2 ed. São Paulo: Atlas, 1989.

MEIRELLES, H. L. Direito administrativo brasileiro. 20 ed. São Paulo: Malheiros, 1995.

MINTZBERG, H. Criando organizações eficazes. 2. ed. São Paulo: Atlas, 2003.

. In: MINTZBERG, H. \& QUINN, J. B. O processo de estratégia. 3 ed. Porto Alegre: Bookman, 2001.

. et al. Safári de Estratégia: um roteiro pela selva do planejamento estratégico. Porto Alegre: Bookman, 2000.

116

Organization design: fashion or fit? Harvard Business Review. Jan/Feb 1981. p. 103-

MONTAÑO, C. Terceiro Setor e questão social: crítica ao padrão emergente de intervenção social. São Paulo: Cortez, 2002.

MOORE, M. H. The public value scorecard: a rejoinder and a alternative to "strategic performance measurement and management in non-profit organizations" by Robert Kaplan.

The Hauser Center for Nonprofit Organizations. Working Paper n. 18, mai 2003. Disponível em: <www.ssrn.com>. Acesso em: 21 jul 2003.

MORAES, W. F. A. Características organizacionais de grandes empresas brasileiras: um estudo longitudinal. Encontro Nacional da Associação Nacional dos Programas de PósGraduação em Administração, XVIII. Anais... Curitiba, 1994.

MOREIRA, D. A. Dimensões do desempenho em manufaturas e serviços. São Paulo: Pioneira, 1996.

. Medida da produtividade na empresa moderna. São Paulo: Pioneira, 1991.

MORGAN, G. Imagens da organização. São Paulo: Atlas, 1996. 
MOTTA, F. C. P. O que é burocracia. São Paulo: Brasiliense, 1985. Coleção Primeiros Passos, v. 53.

NEDER, R. T. As ONGs na reconstrução da sociedade civil no Brasil. 1998. Disponível em: $<$ http://www.rits.org.br>. Acesso em: 16 jan. 2004.

NUNES, R. S. Administração universitária: concepções, modelos e estratégias empresariais. Tese de Doutorado. USP. São Paulo, 1998.

OLIVEIRA, F. Brasil: da pobreza da inflação para a inflação da pobreza. . In: Cadernos ABONG. ONGs: identidades e desafios atuais. n. 27, maio 2000. Campinas: Autores Associados, 2000. p. 29-40.

OSBORNE, D.; GAEBLER, T. Reinventando o governo: como o espírito empreendedor está transformando o setor público. 6 ed. Brasília: MH Comunicação, 1995.

PEREIRA, J. C. R. Análise de dados qualitativos: estratégias metodológicas para as ciências da saúde, humanas e sociais. 3 ed. São Paulo: EDUSP, 2001.

PEREIRA, L. C. B. Da administração pública burocrática à gerencial. In: PEREIRA, L. C. B.; SPINK, P. (orgs.). Reforma do estado e administração pública gerencial. 3 ed. Rio de Janeiro: Editora FGV, 1999. p. 237-270.

PIMENTA, C. C. A reforma gerencial do Estado brasileiro no contexto das grandes tendências mundiais. Revista de Administração Pública. v.32, n.5, set./out. 1998. São Paulo. p.173-199.

PINTO, W. S. A racionalidade da práxis administrativa em fundações corporativas. Revista de Administração. v. 38, n. 4, out/dez 2003. p. 330-342.

PRZEWORSKI, A. Sobre o desenho do estado: uma perspectiva agent x principal. In: PEREIRA, L. C. B.; SPINK, P. (orgs.). Reforma do estado e administração pública gerencial. 3 ed. Rio de Janeiro: Editora FGV, 1999. p. 39-73.

REDE DE INFORMAÇÕES PARA O TERCEIRO SETOR. Disponível em: $<$ http://www.rits.org.br>. Acesso em: 11 nov. 2003.

RICHARDSON, R. J. et al. Pesquisa social: métodos e técnicas. 3 ed. São Paulo: Atlas, 1999.

RIFKIN, J. Identidade e natureza do Terceiro Setor. In: IOSCHPE, E. B. (org.). $3^{\circ}$ Setor: desenvolvimento social sustentado. 2 ed. Rio de Janeiro: Paz e Terra, 2000. p. 13-23.

ROCHE, C. Avaliação de impacto dos trabalhos de ONGs: aprendendo a valorizar as mudanças. São Paulo: Cortez, 2000.

RODRIGUES, A. L. Configurações organizacionais em organizações sem fins lucrativos: reflexões para além da simples adoção de modelos. In: VOLTOLINI, R. (org.). Terceiro Setor: planejamento e gestão. São Paulo: SENAC, 2004. p. 121-140.

ROESCH, S. M. A. Gestão de ONGs - rumo a uma agenda de pesquisas que contemple a sua diversidade. Encontro Nacional da Associação Nacional dos Programas de Pós-Graduação em Administração, XXVI. Anais... Salvador, 2002.

ROSA, S. T.; COSTA, A. C. Análise comparativa da eficiência e eficácia de gestão entre organizações do terceiro setor e organizações governamentais: um estudo de casos múltiplos nos serviços de educação infantil. Encontro Nacional da Associação Nacional dos Programas de Pós-Graduação em Administração, XXVII. Anais... Atibaia, 2003. 
ROSSI, C. Ortodoxia leva Lula à reunião da Terceira Via. Folha de São Paulo, São Paulo, 6 jul. 2003. Brasil, p. A16.

SALAMON, L. M. Estratégias para o fortalecimento do Terceiro Setor. In: IOSCHPE, E. B. (org.). $3^{o}$ Setor: desenvolvimento social sustentado. 2 ed. Rio de Janeiro: Paz e Terra, 2000. p. 89-111

. America's nonprofit sector: a primer. 2 ed. New York: The foundation center, 1999.

; ANHEIER, H. K Defining the nonprofit sector: a cross-sectional analysis.

Manchester: Manchester University Press, 1997.

Partners in public service: government-nonprofit relaiton in the modern welfare-state. Baltimore: Johns Hopkins University Press, 1995.

The rise of the nonprofit sector. Foreign Affairs. v. 73, n. 4, Jul/Aug 1994. p. 109-117.

SILVA, A. C. M. et al. Aplicação do Balanced Scorecard em Organizações da Sociedade Civil de Interesse Público - OSCIP: Um Estudo de Caso. Encontro Nacional da Associação Nacional dos Programas de Pós-Graduação em Administração, XXVII. Anais... Atibaia, 2003.

SIMERAY, J. P. A estrutura da empresa: princípios e definições, tipos de estruturas e organogramas. Rio de Janeiro: Livros Técnicos e Científicos, 1977.

SMITH, G. S. Performance evaluation for nonprofits. Nonprofit World. v. 6, n. 1, Jan/Feb 1988. p. 24-26. Disponível em: <www.umi.com/proquest>. Acesso em: 12 set. 2003.

SOCZEK, D. Da negação à parceria: breves comentários sobre as relações ONGs-Estado.

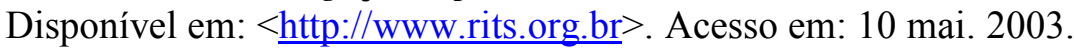

STEVENSON, W. J. Estatística aplicada à administração. São Paulo: Harper \& Row do Brasil, 1981.

STOUT, W. D. A new way to evaluate your organization's performance: measure your use of time. Nonprofit World. v. 19, n. 4, Jul/Aug 2001. p. 28-31. Disponível em:

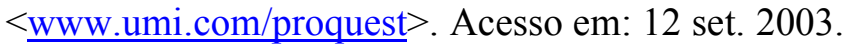

SZAZI, E. Terceiro setor. regulação no Brasil. 2 ed. São Paulo: Peirópolis, 2001.

TACHIZAWA, T. Organizações não governamentais e terceiro setor: criação de ONGs e estratégias de atuação. São Paulo: Atlas, 2002.

TENÓRIO, F. G. (org.). Gestão de ONGs: principais funções gerenciais. 5 ed. Rio de Janeiro: Editora FGV, 2001.

. Um espectro ronda o terceiro setor: o espectro do mercado. Revista de Administração Pública. v.33, n.5, set./out. 1999. São Paulo. p.85-102.

. Gestão social: uma perspectiva conceitual. Revista de Administração Pública. v.32, n.5, set./out. 1998. São Paulo. p.7-23.

TEODÓSIO, A. S. S. O Terceiro Setor de múltiplos atores e de múltiplos interesses: pluralidade ou fragmentação na previsão de políticas públicas? Encontro Nacional da Associação Nacional dos Programas de Pós-Graduação em Administração, XXVII. Anais... Atibaia, 2003.

THOMPSON, A. A. Do compromisso à eficiência? Os caminhos do Terceiro Setor na América Latina. In: IOSCHPE, E. B. (org.). $3^{\circ}$ Setor: desenvolvimento social sustentado. 2 ed. Rio de Janeiro: Paz e Terra, 2000. p. 41-48. 
TORO, J. B. O papel do Terceiro Setor em sociedades de baixa participação (quatro teses para discussão). In: IOSCHPE, E. B. (org.). $3^{\circ}$ Setor: desenvolvimento social sustentado. 2 ed. Rio de Janeiro: Paz e Terra, 2000. p. 35-39.

VASCONCELLOS, E.; HEMSLEY, J. R. Estrutura das organizações: estruturas tradicionais, estruturas para inovação e estrutura matricial. 2 ed. São Paulo: Pioneira, 1989.

VOGT, J. A. Developing your outcome measures: part 3 of a series. Nonprofit World. v. 17, n. 6, Nov/Dec 1999c. p. 40-43. Disponível em: <www.umi.com/proquest $>$. Acesso em: 20 out. 2003.

Five steps to start measuring your outcomes: part 2 of a series. Nonprofit World. v. 17, n. 5, Sep/Oct 1999b. p. 37-39. Disponível em: <www.umi.com/proquest $>$. Acesso em: 12 set. 2003.

Is outcome measurement dead? Nonprofit World. v. 17, n. 4, Jul/Aug 1999a. p. 40-44. Disponível em: <www.umi.com/proquest>. Acesso em: 12 set. 2003.

WILLIAMS, A. A growing role for NGOs in development. Finance \& Development. v. 27, n. 4, dec. 1990. p. 31-33. Disponível em: <www.umi.com/proquest.. Acesso em: 13 out. 2003. 


\begin{abstract}
APÊNDICES
Apêndice A - Roteiro de Entrevista

Apêndice B - Lista das Organizações Não-Governamentais que Participaram da Pesquisa, por Ordem Alfabética
\end{abstract}




\section{Apêndice A - Roteiro de Entrevista \\ Bloco I - Identificação da Entidade e do Respondente}

Para iniciar, gostaria da sua gentileza em me fornecer algumas informações sobre a entidade e, também, sobre o(a) $\operatorname{Sr}(a)$ :

1.1 Nome da Entidade:

1.2 Ano de fundação:

1.3 Missão da Entidade:

1.4 Constituição Jurídica:

1.5 Nome do Respondente:

1.6 Cargo/Função Ocupada:

1.7 Tempo de colaboração nesta Entidade:

1.8 Idade: $\left|\_\right| \_$anos

1.9 Formação Acadêmica: 


\section{Bloco II - Indicadores Qualitativos/Quantitativos}

2.1 Vamos começar falando da qualidade oferecida na prestação dos serviços. Vou elencar itens que indicam o COMPROMETIMENTO da Entidade quanto à SATISFAÇÃO dos BENEFICIÁRIOS através da QUALIDADE DOS SERVIÇOS PRESTADOS. Gostaria da sua indicação de três principais itens considerados pela Entidade nesse tocante:

( ) Prestar serviços dentro de especificações/padrões estabelecidos.

( ) Manter um relacionamento com polidez e respeito com os beneficiários.

( ) Atender um maior número de beneficiários com o mesmo volume de recursos.

( ) Identificar as necessidades dos beneficiários.

( ) Ser ágil no tempo de resposta na prestação dos serviços.

( ) Outros. Quais?

2.2 $\mathrm{O}$ (a) $\mathrm{Sr}(\mathrm{a})$ poderia me informar o número de BENEFICÍARIOS DIRETOS (relacionados com a atividade central - atividade fim - da entidade) atendidos durante o ano de 2002: beneficiários diretos.

2.3 Agora, eu preciso de informações sobre a QUANTIDADE DE COLABORADORES da Entidade por vínculos de trabalho e posição:

\begin{tabular}{|l|l|l|l|l|}
\hline \multicolumn{1}{|c|}{ Posição/Vínculo de Trabalho } & CLT & Autônomos & Voluntários & Outros \\
\hline 2.4.1 Diretoria & & & & \\
\hline 2.4 .2 Conselho Fiscal & & & & \\
\hline 2.4 .3 Equipe Administrativa & & & & \\
\hline 2.4.4 Equipe Técnica & & & & \\
\hline 2.4 .5 Associados & & & & \\
\hline 2.4.6 Outros & & & & \\
\hline
\end{tabular}

Outras Posições:

Outros vínculos:

2.4 O(a) Sr(a) poderia me informar o valor dos seguintes itens da DESPESA em 2002:

\subsubsection{Despesa Total: R $\$$}

2.4.2 Despesa Administrativa (incluindo pessoal administrativo): $\mathrm{R} \$$

2.4.3 Despesa na Prestação de Serviços e de Pessoal: R\$ 
2.5 $\mathrm{O}$ (a) $\mathrm{Sr}$ (a) poderia me informar o volume de RECEITA por fonte obtida pela Entidade em 2002:

2.5.1 Doações Individuais: $\mathrm{R} \$$

2.5.2 Fundações Internacionais: $\mathrm{R} \$$

2.5.3 Fundações Nacionais: R\$

2.5.4 Governo: $\mathrm{R} \$$

2.5.5 Prestação de Serviços: RS

2.5.6 Outras fontes: $\mathrm{R} \$$

2.6 Para verificar a performance de uma organização são utilizados indicadores, por favor, marque o(s) indicador(es) de desempenho utilizado(s) por esta Entidade:

( ) Relatórios descritivos destacando as atividades desenvolvidas;

( ) Quantidade de beneficiários;

( ) Análise financeira;

( ) Quantidade de projetos desenvolvidos;

( ) Outros 


\section{Bloco III - Definição dos Parâmetros de Design da Estrutura Organizacional}

3.1 Basicamente, as estruturas organizacionais podem ser caracterizadas como:

( ) Funcionais - agrupadas por atividades que possuem afinidades de propósitos e objetivos.

( ) Por projeto - mercados.

( ) Matricial - funcional e por mercado.

Você diria que predominantemente a estrutura desta entidade é?

\subsection{Pretendo compreender o DESENHO DA ESTRUTURA ORGANIZACIONAL das}

ONGs, por favor, marque a alternativa que melhor reflita a realidade da Entidade quanto aos componentes básicos predominantes da estrutura organizacional:

\begin{tabular}{|l|c|c|c|}
\hline \multicolumn{1}{|c|}{ Componentes Básicos da Estrutura Organizacional } & Muito & Medianamente & Pouco \\
\hline $\begin{array}{l}\text { Especialização Horizontal das Tarefas (existência de definição rigorosa } \\
\text { das tarefas que conduzem a repetição) }\end{array}$ & $($ ) & ( ) & $($ ) \\
\hline $\begin{array}{l}\text { Especialização Vertical das Tarefas (controle ou profundidade que os } \\
\text { colaboradores têm das tarefas realizadas que conduz à uma limitação de } \\
\text { perspectiva, onde não se consegue relacionar o trabalho executado com o } \\
\text { processo por inteiro) }\end{array}$ & $($ ) & & $($ ) \\
\hline $\begin{array}{l}\text { Formalização do Comportamento (predeterminar comportamento dos } \\
\text { colaboradores na execução de suas tarefas) }\end{array}$ & $($ ) & $($ ) & ( ) \\
\hline $\begin{array}{l}\text { Treinamento (processo pelo qual são ensinadas habilidades e } \\
\text { conhecimentos relacionados ao trabalho geralmente complexo) }\end{array}$ & $($ ) & $($ ) & ( ) \\
\hline $\begin{array}{l}\text { Doutrinação (processo formal em que a organização socializa seus } \\
\text { membros em seu próprio benefício quando estes estão sendo admitidos, } \\
\text { de forma a merecerem confiança para tomar decisões e tomar } \\
\text { providências; está relacionada à cultura da organização) }\end{array}$ & $($ ) & $($ ) & ( ) \\
\hline $\begin{array}{l}\text { Planejamento das Ações (especificar resultados em termos de } \\
\text { quantidade, qualidade, custo e outras características específicas) }\end{array}$ & $($ ) & $($ ) & ( ) \\
\hline Controle de Desempenho (monitorar - avaliar-os resultados) & $($ ) & $($ ) & ( ) \\
\hline
\end{tabular}

3.3 Pretendo identificar a utilização de INSTRUMENTOS desenvolvidos para ENCORAJAR CONTATOS entre os colaboradores - p.ex. cargos de interligação, forças-tarefa, estrutura matricial, por favor, marque a alternativa que melhor reflita a realidade da Entidade:

\begin{tabular}{|l|c|}
\hline \multicolumn{1}{|c|}{ Utilização de Instrumentos de Interligação } & Em toda a Organização \\
\hline São Muito Utilizados & $($ ) \\
\hline São Medianamente Utilizados & $($ ) \\
\hline São Pouco Utilizados & $($ ) \\
\hline
\end{tabular}

3.4 Vamos falar sobre a DISTRIBUIÇÃO DO PODER dentro desta Organização. Dos componentes da estrutura organizacional da entidade, indique aqueles que participam do processo de tomada de decisão:

\begin{tabular}{|l|l|l|l|l|l|}
\hline Diretoria & Conselho Fiscal & Equipe Administrativa & Equipe Técnica & Associados & Outros \\
\hline & & & & & \\
\hline
\end{tabular}

Outros: 


\section{Bloco IV - Identificação dos Fatores Situacionais}

4.1 Pretendo entender o ambiente (MERCADO) em que a Entidade atua, assim, por favor, poderia marcar em cada uma das dimensões apenas um número que melhor reflita a realidade da Entidade:

$\begin{array}{llllllll}\text { Estável } & 1 & 2 & 3 & 4 & 5 & \text { Dinâmico } & \square \\ \text { Fácil compreensão (tecnologia) } & 1 & 2 & 3 & 4 & 5 & \text { Difícil } \\ \text { Integrado } & 1 & 2 & 3 & 4 & 5 & \text { Diversificado } \\ \text { Hostil } & 1 & 2 & 3 & 4 & 5 & \text { Magnânimo } & \square\end{array}$

4.2 A Entidade possui algum TÍTULO PÚBLICO? Qual?

4.3 Procurando entender a existência de CONTROLE EXTERNO (capacidade de impor padrões bem definidos) exercido sobre a Entidade, poderia, por favor, dizer-me com que intensidade este é exercido e quem o exerce:

\begin{tabular}{|c|c|c|c|c|c|c|c|c|}
\hline Controle Externo & $\begin{array}{c}\text { Mantened } \\
\text { ores }\end{array}$ & Doadores & $\begin{array}{c}\text { Associad } \\
\text { os }\end{array}$ & $\begin{array}{c}\text { Gover } \\
\text { no }\end{array}$ & $\begin{array}{c}\text { Colaborad } \\
\text { ores }\end{array}$ & $\begin{array}{c}\text { Comuni } \\
\text { dade }\end{array}$ & $\begin{array}{l}\text { Parc } \\
\text { eiros }\end{array}$ & Outros \\
\hline Sempre & () & () & () & () & () & () & () & () \\
\hline Ocasionalmente & () & () & () & () & () & () & () & () \\
\hline Nunca & () & () & () & () & () & () & () & () \\
\hline
\end{tabular}

( ) Outros:

4.4 Para concluir, considerando os fatores listados abaixo, poderia, por favor, indicar-me qual deles foi PREPONDERANTE na determinação da estrutura organizacional de Entidade:

( ) Ambiente

( ) Controle Externo

( ) Consistência entre os diversos parâmetros de design e fatores situacionais

( ) Normas culturais predominantes no ambiente externo

( ) Cultura predominante no ambiente interno

( ) Escolha de quem detém o poder.

4.5 $\mathrm{O}$ (a) $\mathrm{Sr}(\mathrm{a})$ gostaria de acrescentar algum outro comentário? 


\title{
Apêndice B - Lista das Organizações Não-Governamentais que Participaram da Pesquisa, por ordem alfabética.
}

\author{
AAMM - Associacão de Apoio às Meninas e Meninos da Região Sé (ONG1) \\ Ano de Fundação - 1991 (1993 - formalmente). \\ Missão - Promover a defesa dos direitos de crianças e adolescentes em situação de risco. \\ Constituição Jurídica - Associação. \\ Nome do Respondente - Everaldo Santos Oliveira. \\ Cargo/Função Ocupado - Equipe de Coordenação Geral. \\ Tempo de Colaboração nesta Entidade - 5 anos. \\ Idade -30 anos. \\ Formação Acadêmica - Economia. \\ Data da Realização da Entrevista - 14 de novembro de 2003.
}

\section{ABDL - Associacão Brasileira para Desenvolvimento de Lideranças (ONG2)}

Ano de Fundação - 1991.

Missão - Articular lideranças para um mundo sustentável.

Constituição Jurídica - Associação.

Nome do Respondente - Sérgio Talocchi.

Cargo/Função Ocupado - Membro da Área de Desenvolvimento de Projetos.

Tempo de Colaboração nesta Entidade - 1 ano.

Idade -32 anos.

Formação Acadêmica - Economia.

Data da Realização da Entrevista - 10 de maio de 2004.

\section{AC - Acão da Cidadania São Paulo S/C (ONG3)}

Ano de Fundação - 1993.

Missão - Criar espaços de cidadania, a partir do enfrentamento à fome, à miséria e a todo tipo de discriminação; sensibilizando e mobilizando o conjunto da sociedade, respeitando a diversidade e estabelecendo parcerias compromissadas com a construção de políticas de direitos.

Constituição Jurídica - Associação.

Nome do Respondente - Nadja Faraone.

Cargo/Função Ocupado - Coordenadora Executiva.

Tempo de Colaboração nesta Entidade - 10 anos.

Idade -56 anos.

Formação Acadêmica - Pedagoga (Pós-Graduada em Jornalismo).

Data da Realização da Entrevista - 08 de dezembro de 2003.

\section{ACÃO EDUCATIVA - Acão Educativa - Assessoria, Pesquisa e Informacão (ONG4)}

Ano de Fundação - 1994.

Missão - Propor ações educativas e culturais, visando a promoção da justiça social.

Constituição Jurídica - Associação.

Nome do Respondente - Alexandre von Bloedau.

Cargo/Função Ocupado - Supervisor Financeiro e Administrativo.

Tempo de Colaboração nesta Entidade - 2 anos.

Idade -33 anos.

Formação Acadêmica - Administrador.

Data da Realização da Entrevista - 18 de maio de 2004. 


\section{CDD - BR - Católicas pelo Direito de Decidir (ONG7)}

Ano de Fundação - 1993 (1995 - ano de constituição como ONG).

Missão - Lutar pelos direitos das mulheres, em relação ao controle da própria sexualidade, ao aborto, à concepção e à contracepção, cruzando essa problemática com as crenças e práticas religiosas.

Constituição Jurídica - Associação.

Nome do Respondente - Marta Vieira.

Cargo/Função Ocupado - Assistente Administrativa.

Tempo de Colaboração nesta Entidade - 1 ano e 6 meses.

Idade -29 anos.

Formação Acadêmica - Administração.

Data da Realização da Entrevista - 09 de dezembro de 2003.

CDHEP - CL - Centro de Direitos Humanos e Educacão Popular de Campo Limpo (ONG8)

Ano de Fundação - 1981 (1982 - formalmente).

Missão - Lutar por uma sociedade onde as pessoas se sintam cidadãs responsáveis e lutem para que seus direitos sejam respeitados.

Constituição Jurídica - Associação.

Nome do Respondente - Silene Amorim.

Cargo/Função Ocupado - Educadora.

Tempo de Colaboração nesta Entidade - 1 ano e 6 meses.

Idade -33 anos.

Formação Acadêmica - Administração (Pós-Graduanda em Arte Terapia).

Data da Realização da Entrevista - 03 de dezembro de 2003.

\section{CEBRAP - Centro Brasileiro de Análise e Planejamento (ONG9)}

Ano de Fundação - 1969.

Missão - Desenvolver pesquisa e assessoramento na área de Ciências Humanas.

Constituição Jurídica - Associação.

Nome do Respondente - Miriam Dolhnikoff.

Cargo/Função Ocupado - Diretora Administrativo-Financeira e Coordenadora de Projetos.

Tempo de Colaboração nesta Entidade - 16 anos.

Idade -43 anos.

Formação Acadêmica - História.

Data da Realização da Entrevista - 26 de novembro de 2003.

\section{CEDAP - Centro de Educação e Assessoria Popular (ONG11)}

Ano de Fundação - 1987

Missão - Desenvolver projetos de educação para a cidadania junto a grupos populares de

Campinas e região, favorecendo o fortalecimento de sua organização e estimulando estratégias coletivas de participação e transformação da realidade social e ambiental, tendo como valores fundamentais a democracia e a solidariedade.

Constituição Jurídica - Associação.

Nome do Respondente - Edith Aparecida Bortolozo.

Cargo/Função Ocupado - Coordenadora Executiva

Tempo de Colaboração nesta Entidade - 5anos.

Idade -47 nos.

Formação Acadêmica - Assistente Social, Especialização em Psicodrama Pedagógico.

Data da Realização da Entrevista - 08 de junho de 2004. 
CEERT - Centro de Estudos das Relações do Trabalho e Desigualdades (ONG13)

Ano de Fundação - 1990.

Missão - Conjugar produção de conhecimento com programas de intervenção no campo das relações raciais e de gênero, buscando a promoção da igualdade de oportunidades e tratamento e o exercício efetivo da cidadania.

Constituição Jurídica - Associação.

Nome do Respondente - Shirley Santos.

Cargo/Função Ocupado - Assessora Geral.

Tempo de Colaboração nesta Entidade -8 anos.

Idade -29 anos.

Formação Acadêmica - Psicóloga.

Data da Realização da Entrevista - 20 de maio de 2004.

CENPEC - Centro de Estudos e Pesquisas em Educacão, Cultura e Ação Comunitária (ONG14)

Ano de Fundação - 1987.

Missão - Desenvolver ações que contribuam para a melhoria da qualidade do ensino público, subsidiando a implementação de políticas públicas e privilegiando o aprimoramento dos agentes educacionais.

Constituição Jurídica - Associação.

Nome do Respondente - Maria Aparecida Forli (Cida Forli) e Thaís Iervolino.

Cargo/Função Ocupado - Coordenadora Administrativo-Financeira e Assessoria de Comunicação.

Tempo de Colaboração nesta Entidade - 8meses e 4 anos.

Idade -46 anos.

Formação Acadêmica - Nutricionista.

Data da Realização da Entrevista - 04 de junho de 2004.

CFSS - Coletivo Feminista Sexualidade e Saúde (ONG17)

Ano de Fundação - 1985.

Missão - Promover a saúde integral e os direitos das mulheres a partir de uma perspectiva feminista.

Constituição Jurídica - Associação.

Nome do Respondente - Lenira Politano da Silveira.

Cargo/Função Ocupado - Assistente de Pesquisa.

Tempo de Colaboração nesta Entidade - 5 anos.

Idade -41 anos.

Formação Acadêmica - Psicóloga.

Data da Realização da Entrevista - 06 de maio de 2004.

\section{CGGDH - Centro Gaspar Garcia de Direitos Humanos (ONG18)}

Ano de Fundação - 1984.

Missão - Contribuir à integração e inclusão social de moradores de cortiços, favelas, habitações precárias, pessoas em situação de rua e catadores de materiais recicláveis, visando à melhoria de suas condições de vida, através de processos de educação popular, defesa dos direitos e intervenção nas políticas públicas, priorizando a região central de São Paulo.

Constituição Jurídica - Associação.

Nome do Respondente - René Ivo Gonçalves.

Cargo/Função Ocupado - Coordenador. 
Tempo de Colaboração nesta Entidade - 15 anos.

Idade -45 anos.

Formação Acadêmica - Engenheiro Civil.

Data da Realização da Entrevista - 26 de maio de 2004.

\section{CISMOP - Centro de Investigacão Social e Solidariedade aos Movimentos Populares}

\section{(ONG19)}

Ano de Fundação - 1993.

Missão -.

Constituição Jurídica - Associação.

Nome do Respondente - Tânia Maria Pereira da Silva.

Cargo/Função Ocupado - Secretaria Geral.

Tempo de Colaboração nesta Entidade - 8 anos.

Idade -25 anos.

Formação Acadêmica - Fundamental Completo.

Data da Realização da Entrevista - 08 de junho de 2004.

\section{CPI - SP - Comissão Pró-Índio de São Paulo (ONG22)}

Ano de Fundação - 1979.

Missão - Dar visibilidade à diversidade sócio-cultural e étnica da sociedade brasileira e às diversas formas de ocupação da terra dela decorrentes; Lutar pelo reconhecimento dos direitos territoriais dos diversos grupos sociais e étnicos da sociedade brasileira beneficiários das ações da CPI-SP - pelo Estado; Apoiar a organização dos beneficiários para que estes possam ampliar sua capacidade de exercer a cidadania; Lutar pelo fim da violência contra os direitos humanos fundamentais e coletivos; Defender, preservar e promover a conservação do meio ambiente e a promoção do desenvolvimento sustentado, utilizando-se dos instrumentos legais em juízo e fora dele; e Promover o estudo e a ampliação de novos modelos sócio-produtivos e de sistemas alternativos de produção e comércio visando melhorias para os grupos beneficiários.

Constituição Jurídica - Associação.

Nome do Respondente - Jana D’Ávila.

Cargo/Função Ocupado - Gerente Administrativo.

Tempo de Colaboração nesta Entidade - 1 ano e 6 meses.

Idade -36 anos.

Formação Acadêmica - Administração.

Data da Realização da Entrevista - 20 de novembro de 2003.

\section{ECOAR - Instituto Ecoar para Cidadania (ONG25)}

Ano de Fundação - 1992.

Missão - Discutir questões ambientais emergentes e colaborar para a construção de uma sociedade sustentável e em equilíbrio com a natureza.

Constituição Jurídica - Associação.

Nome do Respondente - José Luciano Oliveira Araújo.

Cargo/Função Ocupado - Coordenação de Projetos.

Tempo de Colaboração nesta Entidade - 5 anos.

Idade -41 anos.

Formação Acadêmica - Filosofia e História.

Data da Realização da Entrevista - 12 de maio de 2004. 


\section{ECOS - Comunicacão em Sexualidade (ONG27)}

Ano de Fundação - 1989.

Missão - Contribuir na promoção e transformação de valores e comportamentos relacionados a sexualidade, saúde e direitos reprodutivos, sob a ótica da erradicação das discriminações de idade, classe, raça e gênero.

Constituição Jurídica - Associação.

Nome do Respondente - Osmar de Paula Leite.

Cargo/Função Ocupado - Diretor Financeiro.

Tempo de Colaboração nesta Entidade - 16 anos.

Idade -57 anos.

Formação Acadêmica - Matemático.

Data da Realização da Entrevista - 19 de maio de 2004.

\section{ESPACO - Formacão, Assessoria e Documentacão (ONG28)}

Ano de Fundação - 1987.

Missão - Desenvolver atividades voltadas à preservação do meio ambiente, educação de jovens e adultos e defesa dos direitos sociais.

Constituição Jurídica - Associação.

Nome do Respondente - Mauro de Queiroz.

Cargo/Função Ocupado - Presidente.

Tempo de Colaboração nesta Entidade - 17 anos.

Idade -70 anos.

Formação Acadêmica - Jornalista e Teólogo.

Data da Realização da Entrevista - 11 de maio de 2004.

\section{FÈ E ALEGRIA - SP - Fundação Fé e Alegria do Brasil - SP (ONG30)}

Ano de Fundação - 1987.

Missão - Promover uma educação integral, de qualidade, comprometida com os princípios cristãos de igualdade, justiça e solidariedade, capaz de tornar crianças e adolescentes em sujeitos autônomos, visando à transformação social, em parceria com as camadas populares.

Constituição Jurídica - Fundação.

Nome do Respondente - Marialice.

Cargo/Função Ocupado - Coordenadora de Escritório.

Tempo de Colaboração nesta Entidade - 5 anos.

Idade -43 anos.

Formação Acadêmica - Pedagoga.

Data da Realização da Entrevista - 11 de dezembro de 2003.

GAPA - SP - Grupo de Apoio à Prevencão de AIDS - SP (ONG31)

Ano de Fundação - 1982 (1985 - formalmente).

Missão - Defesa dos Direitos Humanos e Integração das Pessoas Portadoras de AIDS.

Constituição Jurídica - Associação.

Nome do Respondente - Amasília Abreu (Margarida).

Cargo/Função Ocupado - Membro da Diretoria e Coordenadora de Eventos.

Tempo de Colaboração nesta Entidade - 10 anos.

Idade -75 anos.

Formação Acadêmica - $2^{\circ}$ Grau.

Data da Realização da Entrevista - 17 de novembro de 2003. 


\section{GELEDÉS - Instituto da Mulher Negra (ONG32)}

Ano de Fundação - 1988.

Missão - Combate ao racismo e ao sexismo, a valorização e promoção das mulheres negras, em particular, e da comunidade negra em geral.

Constituição Jurídica - Associação.

Nome do Respondente - Solimar Carneiro.

Cargo/Função Ocupado - Presidenta.

Tempo de Colaboração nesta Entidade - 17 anos.

Idade -48 anos.

Formação Acadêmica - Superior Incompleto.

Data da Realização da Entrevista - 01 de junho de 2004.

\section{GIV - Grupo de Incentivo à Vida (ONG33)}

Ano de Fundação - 1990.

Missão - Propiciar melhores alternativas de qualidade de vida, tanto no âmbito social como no da saúde física e mental, a toda pessoa portadora do HIV/AIDS.

Constituição Jurídica - Associação.

Nome do Respondente - Gil Casimiro e Edson Arata.

Cargo/Função Ocupado - Presidente e Secretário.

Tempo de Colaboração nesta Entidade - 8 anos e 7 anos.

Idade -38 anos e 40 anos.

Formação Acadêmica - Administração e Técnico em Informática.

Data da Realização da Entrevista - 27 de novembro de 2003 com retorno em 11 de dezembro de 2003.

\section{GREENPEACE - Associacão Civil Greenpeace (ONG34)}

Ano de Fundação - 1990.

Missão - Proteger a diversidade da vida em todas as suas formas; combater a destruição e o uso predatório dos oceanos, do solo, do ar e das fontes de água doce da Terra; pôr um fim à ameaça nuclear, promovendo o desarmamento e a não-violência; constituir uma vida saudável e segura para as gerações futuras.

Constituição Jurídica - Associação.

Nome do Respondente - Wilson Mosca.

Cargo/Função Ocupado - Diretor Financeiro.

Tempo de Colaboração nesta Entidade - 7 meses.

Idade -31 anos.

Formação Acadêmica - Economia.

Data da Realização da Entrevista - 26 de novembro de 2003.

\section{IBEAC - Instituto Brasileiro de Estudos e Apoio Comunitário Queiroz Filho (ONG36)}

Ano de Fundação - 1981.

Missão - Contribuir para a construção e fortalecimento de uma cultura de direitos humanos, cidadania ativa, democracia participativa e solidária, por meio da organização, conscientização e mobilização de setores da sociedade, a partir de realidades locais e regionais.

Constituição Jurídica - Associação.

Nome do Respondente - Eunice Freire.

Cargo/Função Ocupado - Coordenadora Pedagógica.

Tempo de Colaboração nesta Entidade - 23 anos.

Idade -74 anos. 
Formação Acadêmica - Comunicação.

Data da Realização da Entrevista - 12 de dezembro de 2003.

\section{IDEC - Instituto Brasileiro de Defesa do Consumidor (ONG37).}

Ano de Fundação - 1987.

Missão - Promover a educação, a conscientização, a defesa dos direitos do consumidor e a ética nas relações de consumo, com total independência política e econômica.

Constituição Jurídica - Associação.

Nome do Respondente - Marcos Pó.

Cargo/Função Ocupado - Consultor.

Tempo de Colaboração nesta Entidade - 9 anos.

Idade -32 anos.

Formação Acadêmica - Engenheiro (Mestrando em Administração Pública).

Data da Realização da Entrevista - 02 de dezembro de 2003.

\section{Instituto Avisa Lá - Formação Continuada de Educadores (ONG38)}

Ano de Fundação - 1986.

Missão - Melhorar a qualidade da educação por meio do desenvolvimento profissional e pessoal de educadores e do fortalecimento do potencial educativo das escolas e centros educacionais.

Constituição Jurídica - Associação.

Nome do Respondente - Cisele Ortiz.

Cargo/Função Ocupado - Coordenadora de Projetos.

Tempo de Colaboração nesta Entidade - 15 anos.

Idade -48 anos.

Formação Acadêmica - Psicóloga.

Data da Realização da Entrevista - 05 de dezembro de 2003.

\section{IPF - Instituto Paulo Freire (ONG39)}

Ano de Fundação - 1991 (1992 - formalmente).

Missão - Dar continuidade ao legado de Paulo Freire, aproximando pessoas e instituições que trabalham em torno de suas idéias e desenvolvendo pesquisas e práticas nos campos da educação, da cultura e da comunicação que contribuam para a construção de uma sociedade mais democrática e socialmente justa.

Constituição Jurídica - Associação.

Nome do Respondente - Ângela Antunes.

Cargo/Função Ocupado - Diretora Técnico-Pedagógica.

Tempo de Colaboração nesta Entidade - 10 anos.

Idade -42 anos.

Formação Acadêmica - Doutora em Educação.

Data da Realização da Entrevista - 09 de dezembro de 2003.

\section{ISA - Instituto SocioAmbiental (ONG40)}

Ano de Fundação - 1994.

Missão - Defender bens e direitos sociais, coletivos e difusor relativos ao meio ambiente, ao patrimônio cultural, aos direitos humanos e dos povos.

Constituição Jurídica - Associação.

Nome do Respondente - Carlos Macedo.

Cargo/Função Ocupado - Coordenador Desenvolvimento Institucional.

Tempo de Colaboração nesta Entidade - 4 anos. 
Idade -50 anos

Formação Acadêmica - Psicólogo e Educador.

Data da Realização da Entrevista - 10 de fevereiro de 2004.

POLIS - Instituto de Estudos, Formacão e Assessoria em Políticas Sociais (ONG41)

Ano de Fundação - 1987.

Missão - Melhoria da qualidade de vida, o desenvolvimento sustentável, a ampliação dos direitos de cidadania e a democratização da sociedade.

Constituição Jurídica - Associação.

Nome do Respondente - João José de Almeida Nassif.

Cargo/Função Ocupado - Assessor da Diretoria.

Tempo de Colaboração nesta Entidade - 9 meses.

Idade -23 anos.

Formação Acadêmica - Administrador.

Data da Realização da Entrevista - 27 de maio de 2004.

\section{RME - Rede Mulher de Educação (ONG43)}

Ano de Fundação - 1980.

Missão -Empoderamento das mulheres para a conquista de uma sociedade baseada na equidade, na justiça e na sustentabilidade.

Constituição Jurídica - Associação.

Nome do Respondente - Vera Vieira.

Cargo/Função Ocupado - Coordenadora-Executiva e Representante Legal.

Tempo de Colaboração nesta Entidade -8 anos.

Idade -49 anos.

Formação Acadêmica - Jornalista, Especialização em Gestão de Processos Comunicacionais e

Mestrado em Comunicação/Educação (USP/ECA).

Data da Realização da Entrevista - 18 de maio de 2004.

\section{SOF - Sempreviva Organização Feminina (ONG45)}

Ano de Fundação - 1963.

Missão - Contribuir na construção de uma política feminista articulada ao projeto democrático-popular, que esteja presente na formulação de propostas e nos processos organizativos e de luta dos movimentos sociais.

Constituição Jurídica - Associação.

Nome do Respondente - Laís Sales da Costa.

Cargo/Função Ocupado - Gerente Administrativa.

Tempo de Colaboração nesta Entidade - 11 anos.

Idade -41 anos.

Formação Acadêmica - Geógrafa.

Data da Realização da Entrevista - 14 de maio de 2004.

\section{SOS MATA ATLÂNTICA - Fundação SOS Mata Atlântica (ONG46)}

Ano de Fundação - 1986.

Missão - Defender os remanescentes da Mata Atlântica, valorizar a identidade física e cultural das comunidades que os habitam, conservar o rico patrimônio cultural, natural, existentes nessas regiões, buscando seu desenvolvimento sustentável.

Constituição Jurídica - Fundação.

Nome do Respondente - Mario César Mantovani.

Cargo/Função Ocupado - Relações Institucionais. 
Tempo de Colaboração nesta Entidade - 18 anos.

Idade -49 anos.

Formação Acadêmica - Geógrafo.

Data da Realização da Entrevista - 16 de junho de 2004.

\section{SOS SAÚDE MENTAL - Associação SOS Saúde Mental (ONG47)}

Ano de Fundação - 1993.

Missão - Defesa dos direitos de pessoas com transtornos mentais.

Constituição Jurídica - Associação.

Nome do Respondente - Anna Athanázio de Oliveira.

Cargo/Função Ocupado - Presidente.

Tempo de Colaboração nesta Entidade - 12 anos.

Idade -66 anos.

Formação Acadêmica - $1^{\circ}$ Grau.

Data da Realização da Entrevista - 13 de maio de 2004.

\section{SSL - Associação Saúde sem Limites (ONG48)}

Ano de Fundação - 1994.

Missão - Atuar junto às comunidades socialmente excluídas para que estas possam interagir na construção de sistemas oficiais de saúde eficientes, democráticos, culturalmente adequados e capazes de atenderem suas necessidades.

Constituição Jurídica - Associação.

Nome do Respondente - Simone Argentino.

Cargo/Função Ocupado - Assessora Técnica.

Tempo de Colaboração nesta Entidade - 7 anos.

Idade -33 anos.

Formação Acadêmica - Enfermeira.

Data da Realização da Entrevista - 02 de dezembro de 2003.

\section{UCBC - União Cristã Brasileira de Comunicacão Social (ONG49).}

Ano de Fundação - 1969.

Missão - Desenvolver políticas de comunicação e difundi-las por meio de congressos, seminários e cursos de capacitação.

Constituição Jurídica - Associação.

Nome do Respondente - Lígia Gonçalves Dantas.

Cargo/Função Ocupado - Relações Públicas.

Tempo de Colaboração nesta Entidade - 1 mês e 10 dias.

Idade -23 anos.

Formação Acadêmica - Graduanda em Relações Públicas.

Data da Realização da Entrevista - 10 de dezembro de 2003. 